
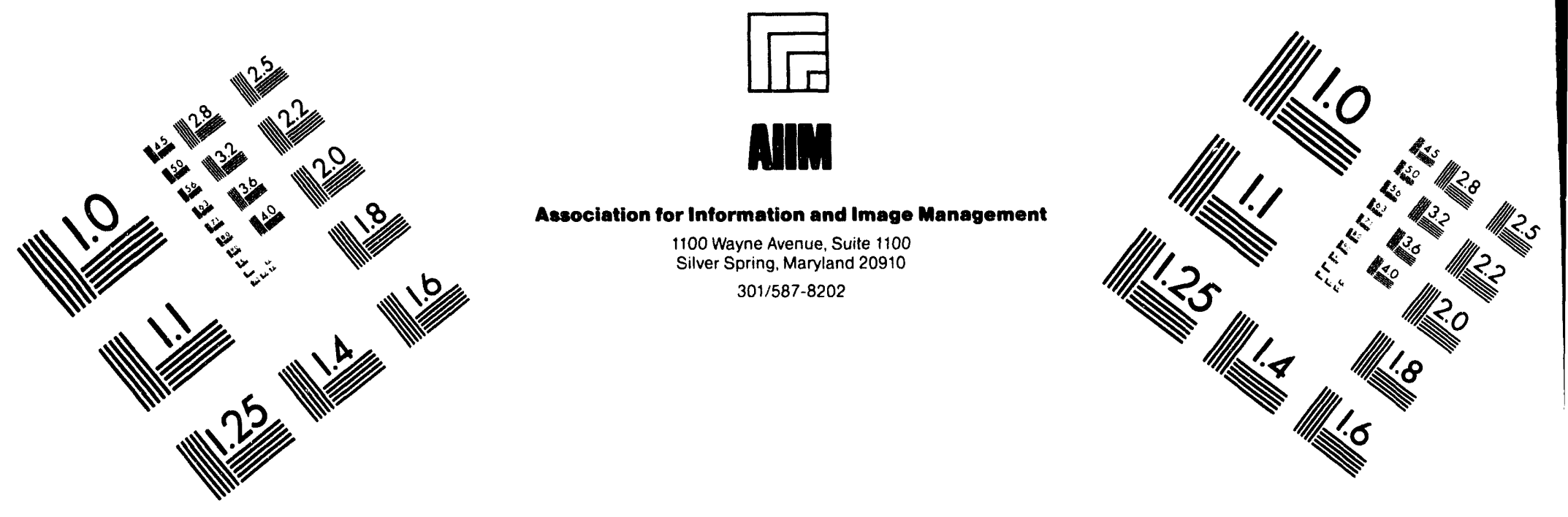

\title{
Centimeter
}

$\begin{array}{llllllllllllllll}1 & 2 & 3 & 4 & 5 & 6 & 7 & 8 & 9 & 10 & 11 & 12 & 13 & 14 & 15 & \mathrm{~mm}\end{array}$

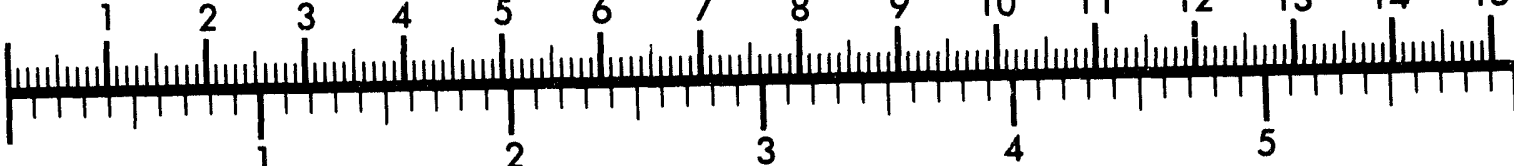
Inches
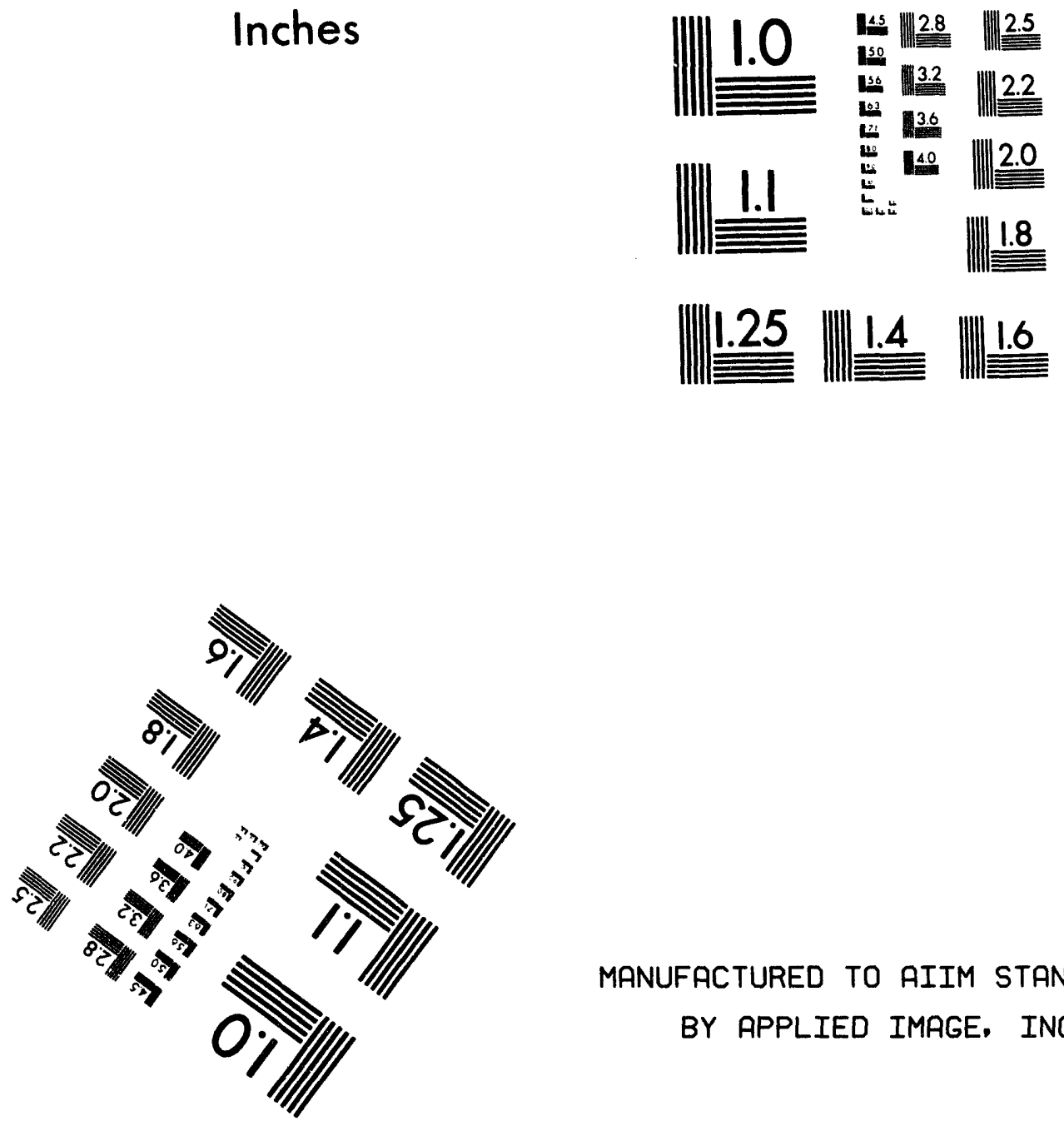

MANUFACTURED TO AIIM STANDARDS

BY APPLIED IMAGE, INC.

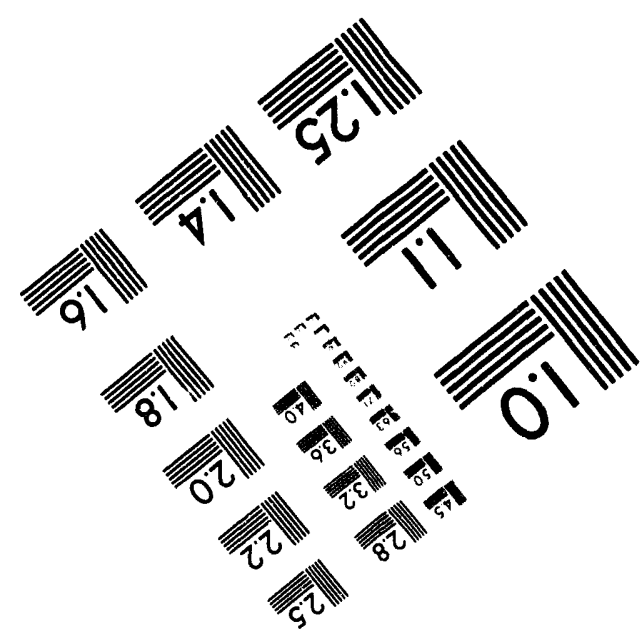



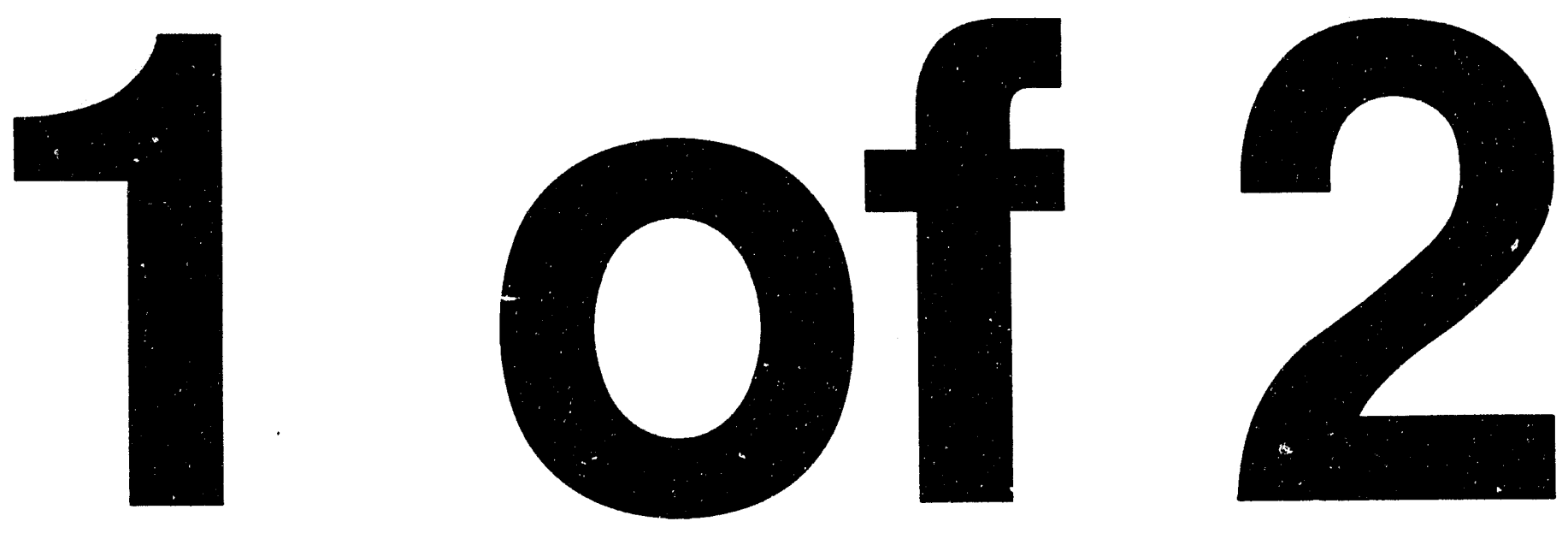
DOE/EIA-0478(93)

Distribution Category UC-98

\section{Uranium Industry Annual 1993}

\section{September 1994}

Energy Information Administration

Office of Coal, Nuclear, Electric and Alternate Fuels

U.S. Department of Energy

Washington, DC 20585

This report was prepared by the Energy Information Administration, the independent statistical and analytical agency within the Department of Energy. The information contained herein should not be construed as advocating or reflecting any policy position of the Department of Energy or of any other organization. 


\section{Preface}

The Uranium Industry Annual provides current statistical data on the U.S. uranium industry for the Congress, Federal and State agencies, the uranium and electric utility industries, and the public. It contains data from the mandatory "Uranium Industry Annual Survey," Form EIA-858 for 1993; historical data collected by the Energy Information Administration (EIA) and by the Grand Junction Projects Office of the Albuquerque Operations Office of the U.S. Department of Energy (DOE); and data gathered by Federal agencies that preceded the DOE. The report was prepared by the Energy Information Administration, the independent agency for data collection and analysis within the U.S. Department of Energy.

Data collected on the "Uranium Industry Annual Survey" (UIAS) provide a comprehensive statistical characterization of the industry's activities for the survey year and include some information about industry plans and commitments for the following year. Where aggregate data are presented in this report, care has been taken to protect the confidentiality of company-specific information while still conveying accurate and complete statistical data. The methodology used in the survey, including data edit and analysis, is described in Appendix A. The history and legal authority, an industry overview, and methodologies used in the estimation of potential uranium resources and uranium reserves are described in Appendix B. A list of respondents to the UIAS is provided in Appendix C. Appendix D consists of the Form ELA-858. Metric versions of selected tables from Chapters 1 and 2 are provided for the convenience of the reader in Appendix E. Standard conversion factors between U.S. customary units of measurement and the International System of Units (SI) are provided in Table E1.

A feature article, "Uranium In Situ Leach Mining in the United States," is included in the Uranium Industry Annual 1993. Questions regarding this article should be addressed to the following individuals at the EIA:

Taesin Chung (202/254-5566)

William Szymanski (202/254-5569)
Data on uranium raw materials activities including exploration activities and expenditures, resources and reserves, mine production of uranium, production of uranium concentrate, and industry employment are presented in Chapter 1.

Data on uranium marketing activities including domestic uranium purchases, commitments by utilities, procurement arrangements, uranium imports under purchase contracts and exports, deliveries to enrichment suppliers, inventories, secondary market activities, and utility market requirements are presented in Chapter 2.

Beginning in survey-year 1984, Form EIA-858, "Uranium Industry Annual Survey," replaced three previous EIA surveys: "Survey of U.S. Uranium Exploration Activity," Form EIA-717; "Survey of United States Uranium Marketing Activity," Form EIA-491; and "U.S. Uranium Industry Financial Survey," Form EIA-854. The Uranium Industry Annual (UIA) report series supersedes two earlier reports namely, the Survey of U.S. Uranium Exploration Activity and the Survey of United States Uranium Marketing Activity, that were based on the previous EIA surveys. The UIA also continues some of the time series of data on the industry and on uranium resources that were presented in the reports Statistical Data of the Uranium Industru (GJO-100) and Uranium Exploration Expenditures and Plans Survey (GJO-103) that were formerly issued by the DOE's Grand Junction Projects Office.

Questions regarding the contents of this report may be directed to:

Survey Management Division, EI-52
Energy Information Administration
U.S. Department of Energy
1000 Independence Avenue, SW
Washington, DC 20585

Questions of a general nature should be directed to Howard L. Walton, Director of the Survey Management Division (202/254-5500); or Noel Balthasar, Chief of the 
Coal and Uranium Data Systems Branch (202/254-5400). Questions of a detailed or technical nature should be referred to the following individuals at the EIA:

Survey Methodology and Operation, Uranium Exploration, Production, and Employment

Charles Johnson (202/254-5568)

Luther Smith (202/254-5565)
Resources and Reserves

Taesin Chung (202/254-5556)

William Szymanski (202/254-5569

Uranium Marketing Activities

Douglas Bonnar (202/254-5560)

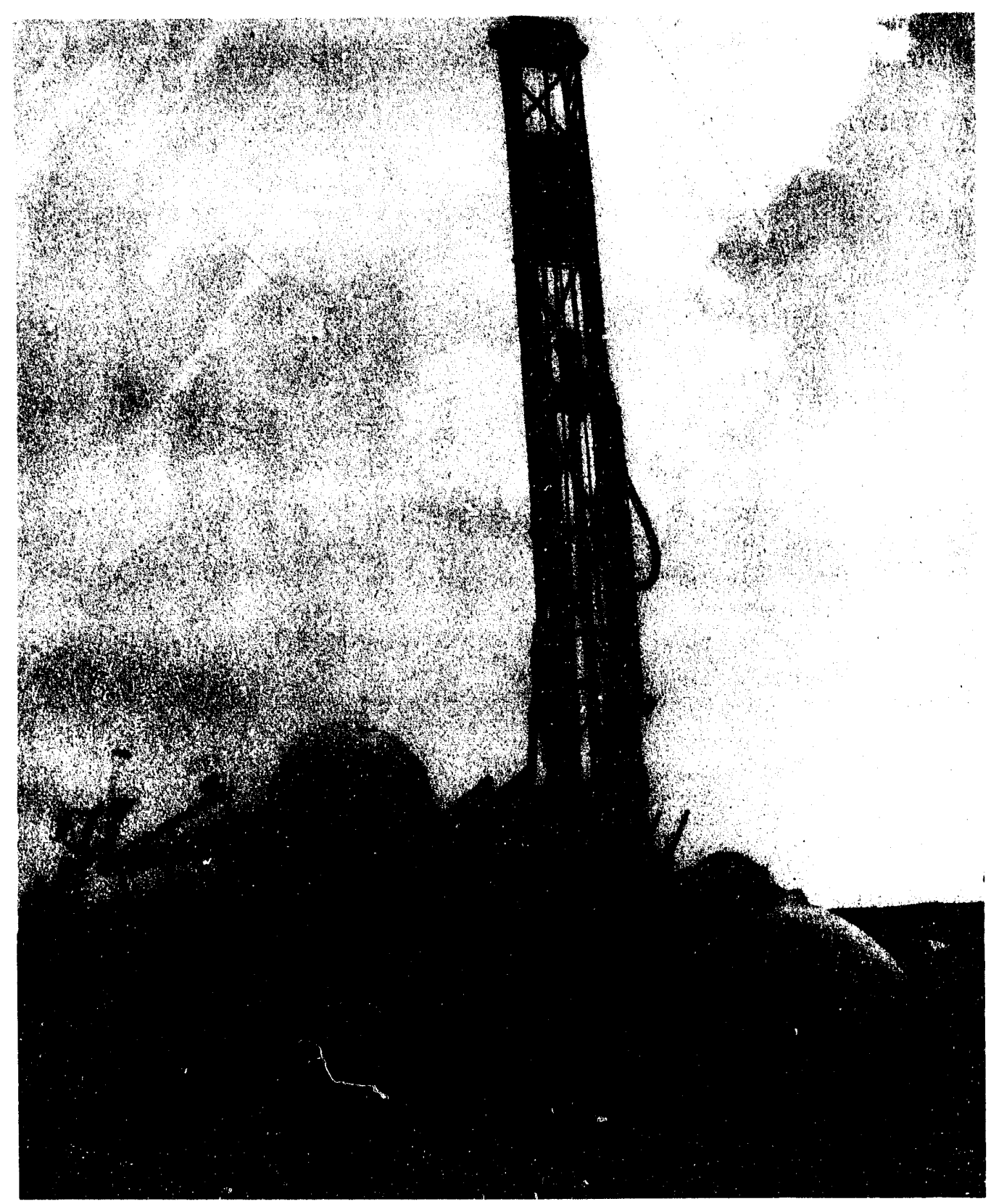

Exploratory drilling is done to obtain data about geologic conditions that are conduclve to the formation of uranlum ore deposits. Here, a field geologist examines samples of rock chips (cuttings) collected from successive layers of rock penetrated during drilling at a remote site. 


\section{Contents}

Page

Feature Article: In Situ Leach Mining in the United States $\ldots \ldots \ldots \ldots \ldots \ldots \ldots \ldots \ldots \ldots \ldots$ ix

Executive Summary $\ldots \ldots \ldots \ldots \ldots \ldots \ldots \ldots \ldots \ldots \ldots \ldots \ldots \ldots \ldots \ldots \ldots \ldots \ldots \ldots \ldots \ldots \ldots \ldots \ldots \ldots \ldots$

1. Uranium Raw Materials Activities $\ldots \ldots \ldots \ldots \ldots \ldots \ldots \ldots \ldots \ldots \ldots \ldots \ldots \ldots \ldots \ldots \ldots \ldots \ldots \ldots$

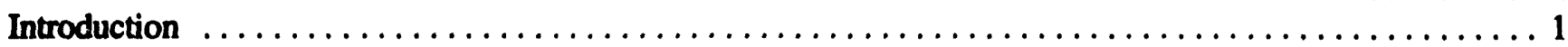

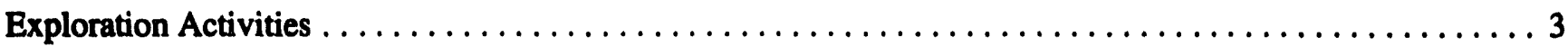

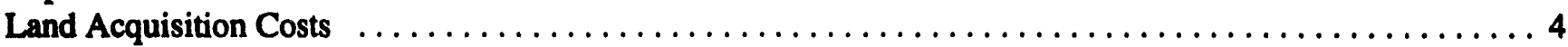

U.S. Uranium Resources and Reserves $\ldots \ldots \ldots \ldots \ldots \ldots \ldots \ldots \ldots \ldots \ldots \ldots \ldots \ldots \ldots \ldots \ldots$

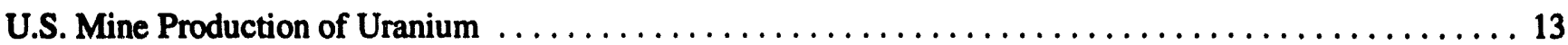

U.S. Uranium Concentrate Production $\ldots \ldots \ldots \ldots \ldots \ldots \ldots \ldots \ldots \ldots \ldots \ldots \ldots \ldots \ldots \ldots \ldots \ldots$

Employment in the Uranium Raw Materials Industry $\ldots \ldots \ldots \ldots \ldots \ldots \ldots \ldots \ldots \ldots \ldots \ldots \ldots \ldots \ldots$

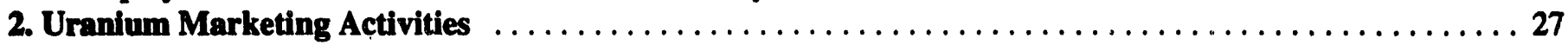

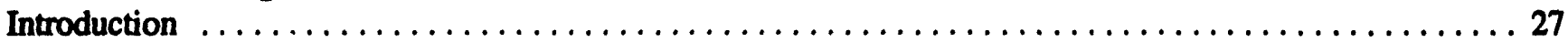

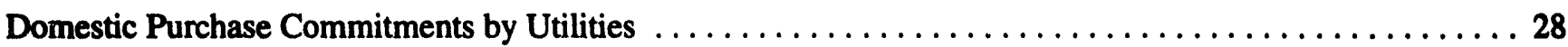

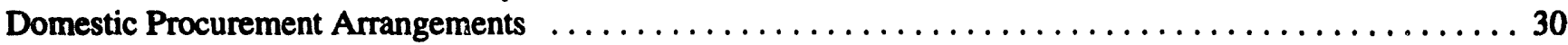

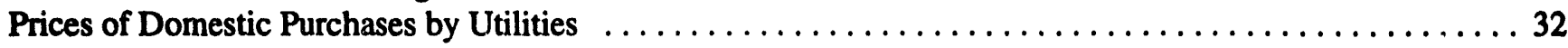

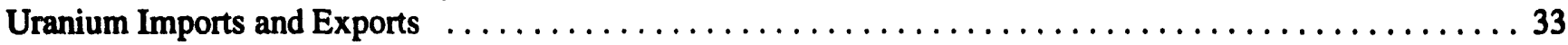

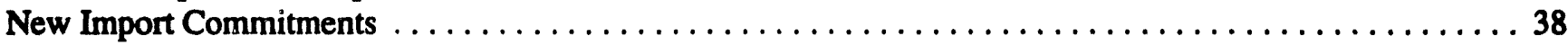

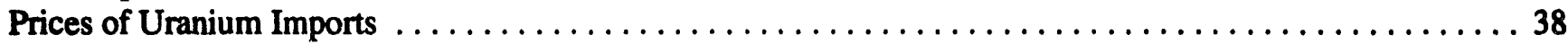

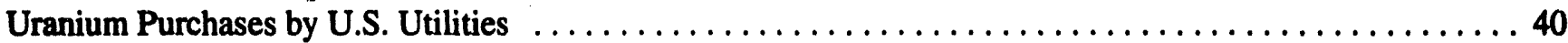

Deliveries to Enrichment Suppliers by U.S. Utilities $\ldots \ldots \ldots \ldots \ldots \ldots \ldots \ldots \ldots \ldots \ldots \ldots \ldots \ldots \ldots \ldots 1$

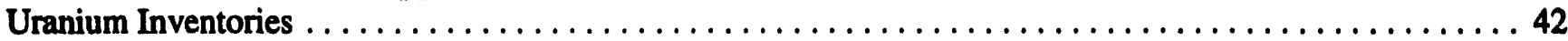

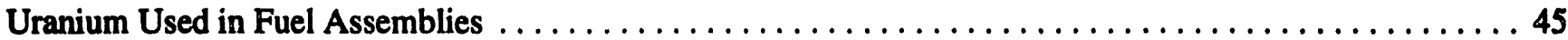

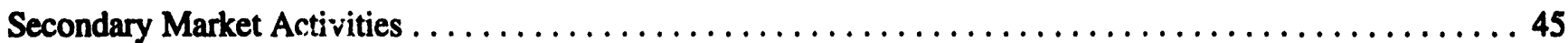

Anticipated Uranium Market Requirements of U.S. Utilities $\ldots \ldots \ldots \ldots \ldots \ldots \ldots \ldots \ldots \ldots \ldots \ldots \ldots 45$

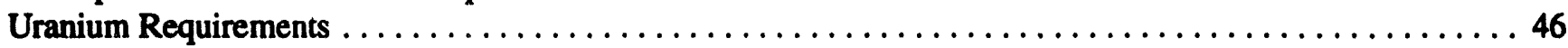

Appendices

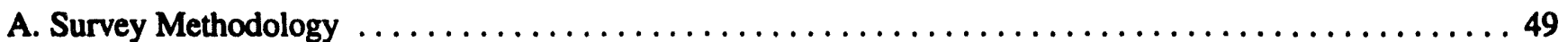

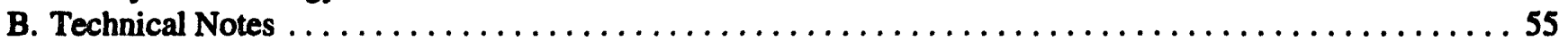

C. Respondents to the Uranium Industry Annual Survey $\ldots \ldots \ldots \ldots \ldots \ldots \ldots \ldots \ldots \ldots \ldots \ldots \ldots$

D. Form EIA-858: Uranium Industry Annual Survey $\ldots \ldots \ldots \ldots \ldots \ldots \ldots \ldots \ldots \ldots \ldots \ldots \ldots$

E. U.S. Customary Units of Measurement, International System of Units (SI),

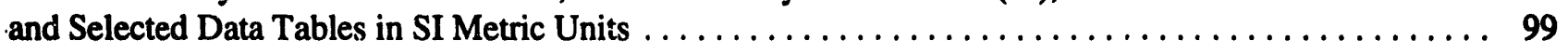

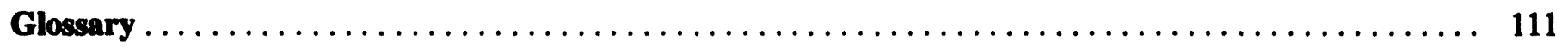


1. U.S. Land Held and Acquired for Uranium Exploration, $1966-1993 \ldots \ldots \ldots \ldots \ldots \ldots \ldots \ldots \ldots \ldots$

2. U.S. Uranium Surface Drilling Activities, $1966-1993 \ldots \ldots \ldots \ldots \ldots \ldots \ldots \ldots \ldots \ldots \ldots \ldots \ldots \ldots 4$

3. U.S. Uranium Drilling by Type of Drilling, $1966-1993 \ldots \ldots \ldots \ldots \ldots \ldots \ldots \ldots \ldots \ldots \ldots \ldots \ldots 6$

4. Surface Drilling by State and Type of Drilling, $1993 \ldots \ldots \ldots \ldots \ldots \ldots \ldots \ldots \ldots \ldots \ldots \ldots \ldots$

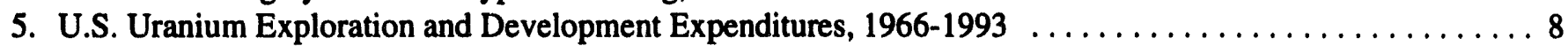

6. Foreign Participation in U.S. Uranium Exploration, $1976-1993 \ldots \ldots \ldots \ldots \ldots \ldots \ldots \ldots \ldots \ldots \ldots \ldots \ldots 9$

7. Planned and Actual U.S. Surface Drilling by Drilling Type and Expenditures, $1981-1994 \ldots \ldots \ldots \ldots \ldots 10$

8. U.S. Potential Uranium Resources by Forward-Cost Category, $1992,1993 \ldots \ldots \ldots \ldots \ldots \ldots \ldots \ldots \ldots 11$

9. Changes in U.S. Uranium by Forward-Cost Category, $1992,1993 \ldots \ldots \ldots \ldots \ldots \ldots \ldots \ldots \ldots \ldots \ldots 11$

10. Uranium Reserves by State and Forward-Cost Category, $1993 \ldots \ldots \ldots \ldots \ldots \ldots \ldots \ldots \ldots \ldots \ldots \ldots$

11. U.S. Uranium Reserves by Mining Method and Forward-Cost Category, $1993 \ldots \ldots \ldots \ldots \ldots \ldots \ldots \ldots 13$

12. U.S. Uranium Mine Production by Mining Method, $1981-1993 \ldots \ldots \ldots \ldots \ldots \ldots \ldots \ldots \ldots \ldots \ldots \ldots$

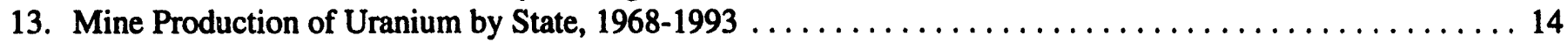

14. Number of U.S. Uranium Mine Operations, $1982-1993 \ldots \ldots \ldots \ldots \ldots \ldots \ldots \ldots \ldots \ldots \ldots \ldots \ldots$

15. Uranium Ore Produced at U.S. Mines and Received at U.S. Mills, $1948-1993 \ldots \ldots \ldots \ldots \ldots \ldots \ldots \ldots 16$

16. Uranium Concentrate Production by State, $1947-1993 \ldots \ldots \ldots \ldots \ldots \ldots \ldots \ldots \ldots \ldots \ldots \ldots \ldots 17$

17. U.S. Uranium Concentrate Processing Operations, $1983-1993 \ldots \ldots \ldots \ldots \ldots \ldots \ldots \ldots \ldots \ldots \ldots \ldots$

18. Operating Status of U.S. Nonconventional Uranium Plants, $1993 \ldots \ldots \ldots \ldots \ldots \ldots \ldots \ldots \ldots \ldots \ldots 20$

19. Operating Status of U.S. Conventional Uranium Mills, $1987-1993 \ldots \ldots \ldots \ldots \ldots \ldots \ldots \ldots \ldots \ldots \ldots$

20. Status of U.S. Conventional Uranium Mills, $1987-1993 \ldots \ldots \ldots \ldots \ldots \ldots \ldots \ldots \ldots \ldots \ldots \ldots \ldots 22$

21. Employment in the U.S. Uranium Industry by Category, $1967-1993 \ldots \ldots \ldots \ldots \ldots \ldots \ldots \ldots \ldots \ldots 24$

22. Employment in the U.S. Uranium Industry by State, $1993 \ldots \ldots \ldots \ldots \ldots \ldots \ldots \ldots \ldots \ldots \ldots \ldots \ldots$

23. Commitments for Delivery of Uranium from Suppliers to U.S. Utilities, 1993-2000 and Later . . . . . . . . . 28

24. New Contracts Signed by U.S. Utilities for Purchases from Suppliers, 1982-1993 . . . . . . . . . . . . . . . 29

25. Origin of Uranium Committed for Delivery to U.S. Utilities from Suppliers, 1993-2000

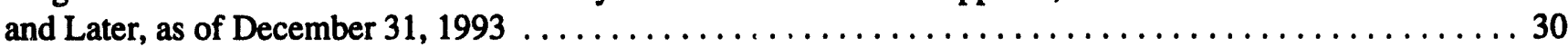

26. Contract Arrangements Specified in Contract-Price Contracts for Delivery of Uranium from Suppliers to U.S. Utilities, $1993-2000$ and Later, as of December $31,1993 \ldots \ldots \ldots \ldots \ldots \ldots \ldots$

27. Floor Price Arrangements Specified in Market-Price Contracts for Delivery of Uranium from

Suppliers to U.S. Utilities, 1993-2000 and Later, as of December 31, $1993 \ldots \ldots \ldots \ldots \ldots \ldots \ldots \ldots$

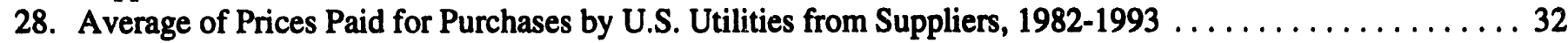

29. Deliveries and Commitments of Uranium Imports and Exports by Transaction Type,

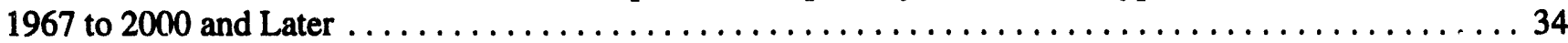

30. Commitments for Delivery of Uranium Imports U.S. Utilities and Suppliers Under Purchase-Contract Imports, 1993-2000 and Later, as of December 31, $1993 \ldots \ldots \ldots \ldots \ldots$

31. Contract Arrangements Specified in Contract-Price Contracts for Delivery of Uranium Imports to U.S. Utilities, 1993-2000 and Later, as of December $31,1993 \ldots \ldots \ldots \ldots \ldots \ldots \ldots \ldots \ldots$

32. Floor Price Arrangements Specified in Market-Price Contracts for Delivery of Uranium Imports to U.S. Utilities, 1993-2000 and Later, as of December $31,1993 \ldots \ldots \ldots \ldots \ldots \ldots \ldots$

33. Historical Commitments and Actual Deliveries of Foreign-Origin Uranium, 1970-1993 . . . . . . . . . . 38

34. Average of Prices Paid for Imported Uranium Delivered to U.S. Utilities and Suppliers, 1983-1993 . . . . 39

35. Price Distributions of Uranium Purchases by U.S. Utilities, $1989-1993 \ldots \ldots \ldots \ldots \ldots \ldots \ldots \ldots \ldots \ldots$. . . 40

36. U.S. Utility Purchases of Uranium and Enrichment Services by Origin, $1993 \ldots \ldots \ldots \ldots \ldots \ldots \ldots \ldots \ldots$

37. Deliveries of Uranium Feed by U.S. Utilities to Enrichment Suppliers, $1993 \ldots \ldots \ldots \ldots \ldots \ldots \ldots \ldots$

38. Projected Shipments of Uranium by Utilities to Domestic and Foreign Enrichment Suppliers, 1994-2003 . . 42

39. Commercial Uranium Inventories at End of Year, $1990-1993 \ldots \ldots \ldots \ldots \ldots \ldots \ldots \ldots \ldots \ldots \ldots \ldots$

40. Commercial and U.S. Government Inventories of Natural and Enriched Uranium

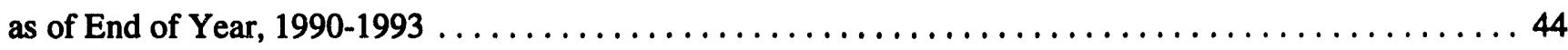

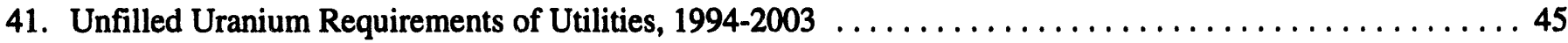


42. Anticipated Uranium Market Requirements of Utilities, 1994-2002, as of December 31, $1993 \ldots \ldots \ldots$. . . 46

A1. Response Statistics for the 1993 Uranium Industry Annual Survey $\ldots \ldots \ldots \ldots \ldots \ldots \ldots \ldots \ldots \ldots$

B1. Potential Uranium Resources at the End of the Year, $1965-1973 \ldots \ldots \ldots \ldots \ldots \ldots \ldots \ldots \ldots \ldots \ldots$

B2. Uranium Endowment by Resource Region, $1993 \ldots \ldots \ldots \ldots \ldots \ldots \ldots \ldots \ldots \ldots \ldots \ldots \ldots \ldots \ldots$

B3. U.S. Potential Uranium Resources by Forward-Cost Category and Resource Class, 1974-1993 . . . . . 64

B4. U.S. Potential Uranium Resources by Forward-Cost Category and Resource Region, $1993 \ldots \ldots \ldots \ldots 6$

B5. Estimated Additional Resources (EAR) and Speculative Resources (SR) in the \$50-per-Pound

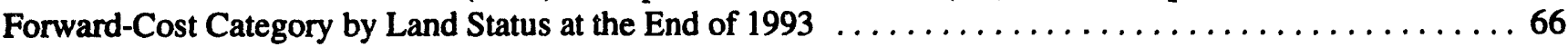

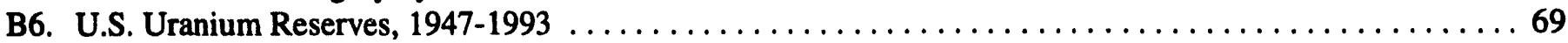

C1. Respondents to the 1993 Uranium Industry Annual Survey $\ldots \ldots \ldots \ldots \ldots \ldots \ldots \ldots \ldots \ldots \ldots \ldots \ldots 73$

E1. Conversion Factors for U.S. Customary Units and SI Metric Units of Measurement . . . . . . . . . 101

E2. U.S. Uranium Drilling by Type of Drilling, $1966-1993 \ldots \ldots \ldots \ldots \ldots \ldots \ldots \ldots \ldots \ldots \ldots \ldots \ldots$

E3. Changes in U.S. Uranium by Forward-Cost Category, $1993 \ldots \ldots \ldots \ldots \ldots \ldots \ldots \ldots \ldots \ldots \ldots \ldots$

E4. U.S. Uranium Mine Production of Uranium by Mining Method, $1981-1992 \ldots \ldots \ldots \ldots \ldots \ldots \ldots \ldots 104$

E5. U.S. Uranium Processing Operations, $1984-1993 \ldots \ldots \ldots \ldots \ldots \ldots \ldots \ldots \ldots \ldots \ldots \ldots \ldots \ldots$

E6. Commitments for Delivery of Uranium from Suppliers to U.S. Utilities, 1993-2000 and Later . . . . . . . . 106

E7. Average of Prices Paid for Purchases by U.S.Utilities from Suppliers, 1982-1993 . . . . . . . . . . 107

E8. Deliveries and Commitments of U.S. Uranium Imports and Exports

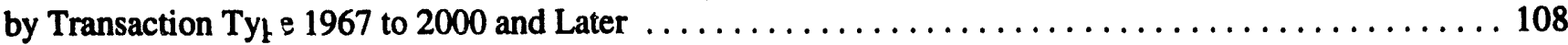

E9. Average of Prices Paid for Imported Uranium Delivered to U.S. Utilities and Suppliers, 1983-1993 . . . . 109

E10. Commercial and U.S. Government Inventories of Natural and Enriched

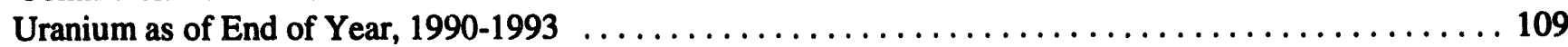

\section{Figures}

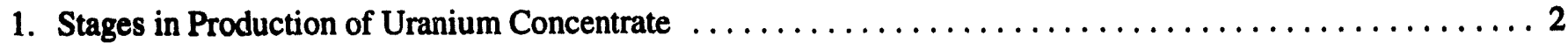

2. U.S. Uranium Exploration and Development Drilling Footage, 1976-1994 . . . . . . . . . . . . . . 5

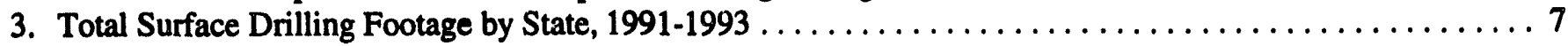

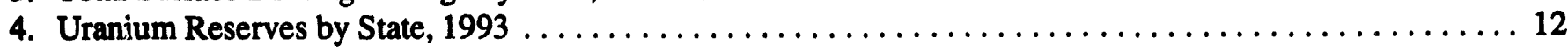

5. U.S. Reserves by Mining Method at the End of $1993 \ldots \ldots \ldots \ldots \ldots \ldots \ldots \ldots \ldots \ldots \ldots \ldots \ldots$

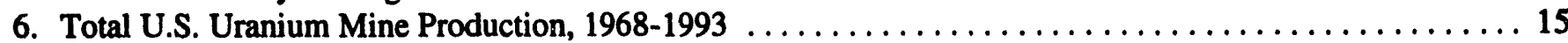

7. U.S. Production of Uranium Concentrate, $1955-1993 \ldots \ldots \ldots \ldots \ldots \ldots \ldots \ldots \ldots \ldots \ldots \ldots$

8. Major U.S. Uranium Reserve Areas and Status of Mills and Plants, $1993 \ldots \ldots \ldots \ldots \ldots \ldots \ldots \ldots \ldots 23$

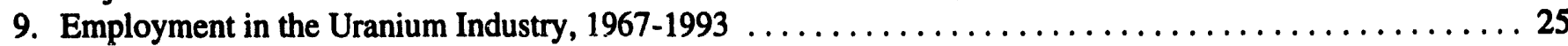

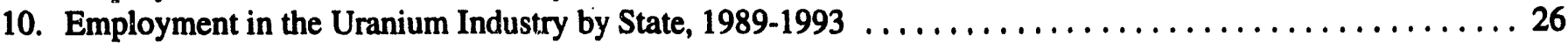

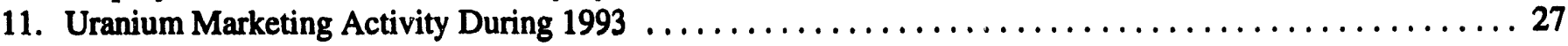

12. Uranium Delivery Commitments to U.S. Utilities from Suppliers, 1993-2000 and Later

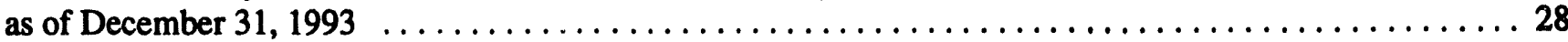

13. Number of New Utility Contracts by Contract Type, $1983-1993 \ldots \ldots \ldots \ldots \ldots \ldots \ldots \ldots \ldots \ldots \ldots 29$

14. Average Price of Uranium Delivered to U.S. Utilities, $1982-1993 \ldots \ldots \ldots \ldots \ldots \ldots \ldots \ldots \ldots \ldots \ldots . \ldots 33$

15. Actual and Committed Imports and Exports of Uranium for Commercial Uses, 1967-2000 and Later . . ... 35

16. U.S. Uranium Imports and Prices, $1983-1993 \ldots \ldots \ldots \ldots \ldots \ldots \ldots \ldots \ldots \ldots \ldots \ldots \ldots \ldots \ldots$

17. Commercial Inventories of Uranium for 1993 and Utility Enrichment Feed Deliveries for 1994-1995, as of December 31, $1993 \ldots \ldots \ldots \ldots \ldots \ldots \ldots \ldots \ldots \ldots \ldots \ldots \ldots \ldots \ldots \ldots \ldots$

18. Anticipated Uranium Market Requirements of Utilities, 1994-2002, as of December 31, $1993 \ldots \ldots$. . . . . 47

B1. Comparison of Historical and Current U.S. and NEA/IAEA Classification Nomenclatures

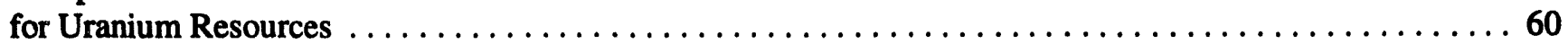

B2. Uranium Resource Regions of the United States $\ldots \ldots \ldots \ldots \ldots \ldots \ldots \ldots \ldots \ldots \ldots \ldots \ldots \ldots \ldots \ldots$

B3. U.S. Reserves by Cumulative Forward-Cost Categories, $1964-1993 \ldots \ldots \ldots \ldots \ldots \ldots \ldots \ldots \ldots \ldots$ 


\title{
Uranium In Situ Leach Mining in the United States
}

\author{
by \\ William N. Szymanskl
}

\section{Introduction}

Uranium production in the United States has declined dramatically from a peak of 43.7 million pounds $\mathrm{U}_{3} \mathrm{O}_{8}$ (16.8 thousand metric tons uranium $(U)^{1}$ ) in 1980 to 3.1 million pounds $\mathrm{U}_{3} \mathrm{O}_{8}$ (1.2 thousand metric tons $U$ ) in $1993 .^{2}$ This decline is attributed to the world uranium market experiencing oversupply and intense competition. Large inventories of uranium accumulated when optimistic forecasts for growth in nuclear power generation were not realized. The other factor which is affecting U.S. uranium production is that some other countries, notably Australia and Canada, possess higher quality uranium reserves that can be mined at lower costs than those of the United States. Realizing its competitive advantage, Canada was the world's largest producer in 1993 with an output of 23.9 million pounds $\mathrm{U}_{3} \mathrm{O}_{8}(9.2$ thousand metric tons $\mathrm{U})$. $^{3}$

The U.S. uranium industry, responding to over a decade of declining market prices, has downsized and adopted less costly and more efficient production methods. The main result has been a suspension of production from conventional mines and mills. Since mid-1992, only nonconventional production facilities, chiefly in situ leach (ISL) mining and byproduct recovery, ${ }^{4}$ have operated in the United States. In contrast, nonconventional sources provided only 13 percent of the uranium produced in $1980 .^{5}$

ISL mining has developed into the most cost efficient and environmentally acceptable method for producing uranium in the United States. The process, also known as solution mining, differs from conventional mining in that solutions are used to recover uranium from the ground without excavating the ore and generating associated solid waste. This article describes the current ISL mining technology and its regulatory approval process, and provides an analysis of the factors favoring ISL mining over conventional methods in a declining uranium market. Because of proprietary considerations, company-specific production data are presented only if previously published by that company.

\section{History of ISL Mining}

ISL mining was tried first on an experimental basis in the Shirley Basin of Wyoming during the early 1960's. Other areas followed with small pilot projects in attempts to recover uranium from deposits that were not suitable for conventional mining. Many of these earlier projects were unsuccessful. The first commercial uranium ISL mine, Clay West in the Texas Gulf Coast area, began operating in 1974. In April 1991, Crow Butte in Nebraska became the latest ISL project to begin commercial production. With licensing secured in March 1992, Smith Ranch in Wyoming is the most recent project to be approved for future operation.

\section{Current Status}

Eleven uranium ISL projects with a total rated plant capacity of 8.4 million pounds $\mathrm{U}_{3} \mathrm{O}_{8}$ ( 3.2 thousand metric tons $U$ ) per year were licensed for commercial operation as of December 31, 1993 (Table FE1). Uranium was produced on a commercial scale at five plants, three in Wyoming and one each in Nebraska and Texas (Figure FE1) although none of the plants was operating at full capacity. Four plants that formerly

\footnotetext{
'The symbol " $U$ " is used to denote contained uranium. The following conversion factor applies: 1 million pounds $\mathrm{U}_{3} \mathrm{O}_{\mathbf{6}}=0.384647$ thousand metric ton $U$. ${ }^{2}$ Energy Information Administration, Uranium Industry Annual 1993, DOE/EIA-0478(93) (Washington, DC, September 1994), Table 16.

${ }^{3}$ Preliminary data from Whillans, Robert, Natural Resources Canada, personal communication, June 15, 1994.

Uranium is commercially recovered as a byproduct during the production of phosphoric acid in Louisiana from phosphate ore mined in Florida. The uranium content is too low for the phosphate ore to be economically mined solely for the uranium.

'Energy Information Administration, Uranium Industry Annual 1991, DOE/EIA-0478(91) (Washington, DC October 1992), Table 18. Due to proprietary considerations, the Energy Information Administration does not publish the ISL and byproduct components of nonconventional uranium production.
} 
Table FE1. Uranlum In Situ Leach Projects Commerclally Licensed In the United States, December 31, 1993

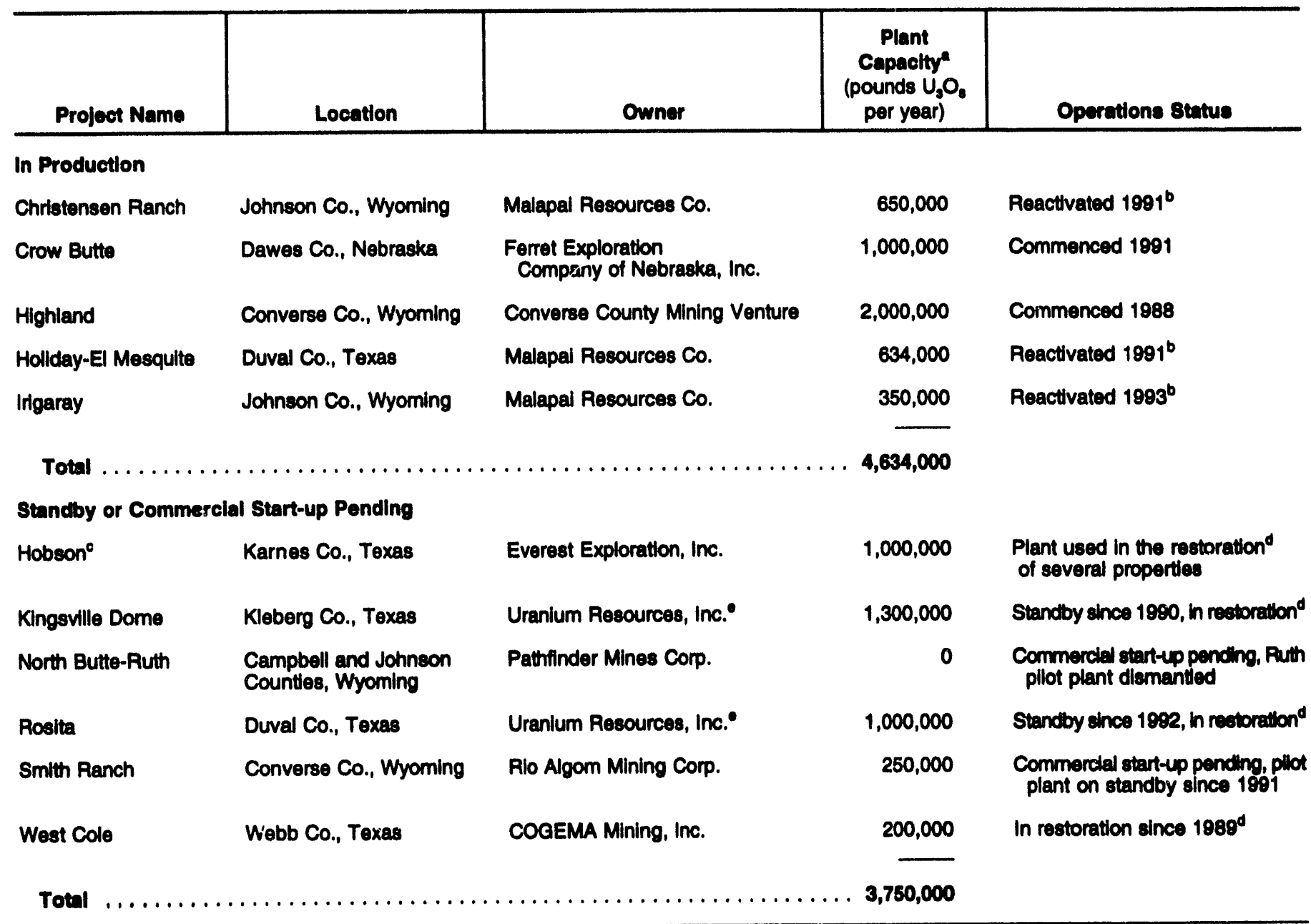

afuted (nameplate) capacly on December 31, 1993. No in stu leach plant was operated at full capacty on Decembar 31, 1893.

bresctivatud after baing closed in 1000 .

opearves of the Hobson property have been mined out. Plant is available to process uranium irom other properties.

Upon cessation of unanium preducten, the quality of the groundwater in the former producing 20 nes must be restored to pre-mining levela. Unantum la recovered during the restoration proceas.

Uranium Resources, Inc. (UAI) concluded a partinembip ecreement with Concord in earty 1984 whereby Concord acquired 52 percent of URI.

Sourcns: Energy Information Adminletrition, Form EIA-858, Uranlum Industry Annual Survey" (1998) and uranlum industry files.

produced are currently inactive. Small amounts of uranium are recovered from these facilities as groundwater in the former production zones is being restored to its pre-mining quality. Two licensed projects have never been in commercial operation. Exploration, development, and permitting activities are being conducted in the reserve areas outlined in Figure FE1.

\section{Evolution of the Industry Structure}

The structure of the U.S. uranium ISL mining industry has evolved as firms have responded to changing economic conditions. In the early 1970 's, multinational oil companies, diversified mining companies, and electric power utilities entered the industry as nuclear power was seen to have a bright future. Diversification into uranium production was seen as a way to profit in a compatible business. Market conditions were also favorable for smaller, more intrepreneurial, companies to enter the uranium industry.

Since the late-1980' $\mathrm{s}$, however, the uranium industry in the United States has undergone fundamental structural changes in response to years of declining market prices (Figure FE2). The industry has seen a consolidation of domestic ownership give rise to foreign investment and 
Figure FE1. Commercially Llcensed In Situ Leach Projects and Major Uranium Reserve Areas Amenable to In Sltu Leaching, December 31, 1993

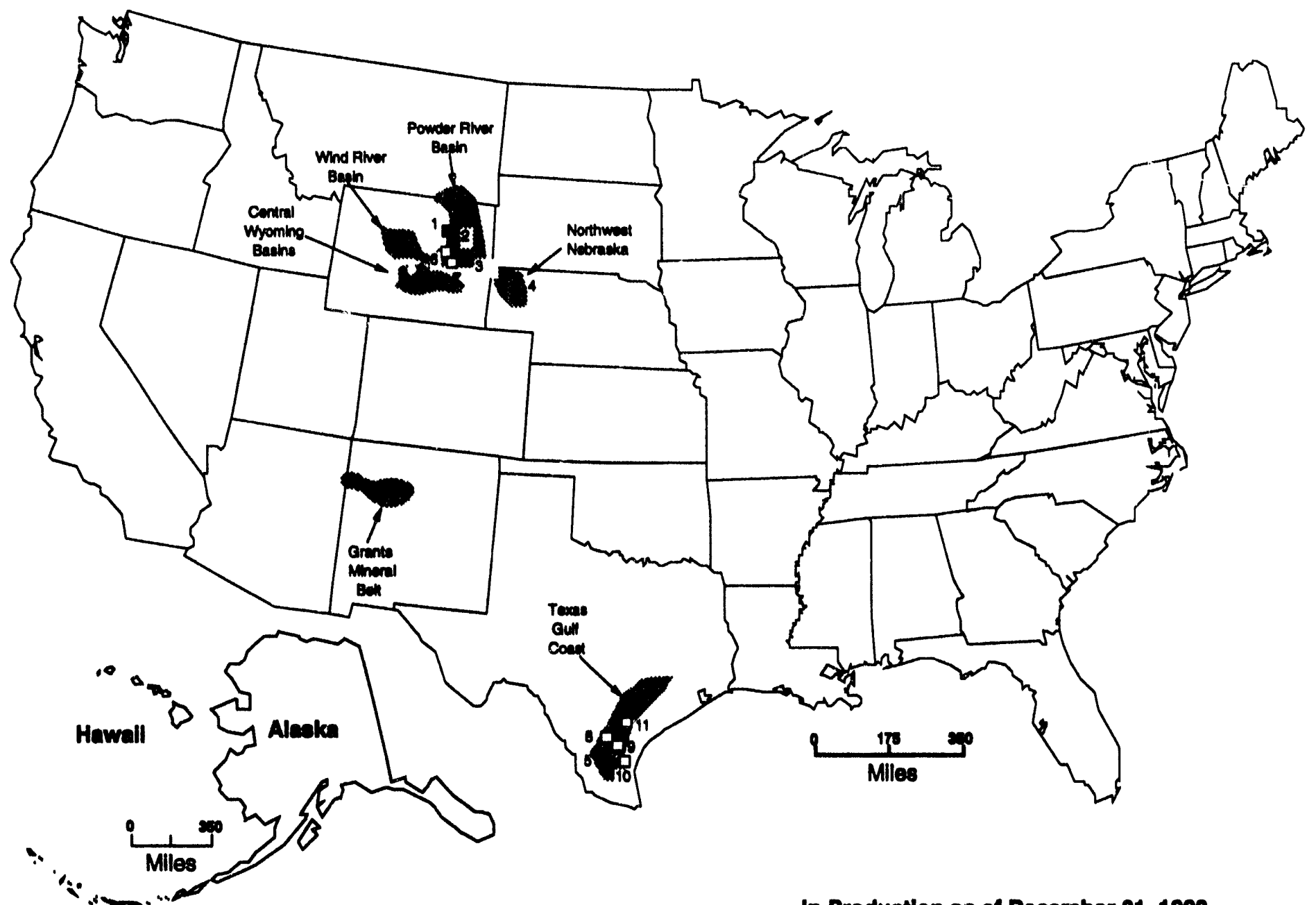

In Production en of Deanmber 31. 1993

1. Malapal Resources, Iingaray

2. Malapal Resources, Chrlstensen Ranch

3. Convarse County Mining Venture, Highiand

4. Ferret Exploration of Nebraska, Crow Butte

5. Malapal Resources, Hollday - El Mesqulte

\begin{tabular}{|c|c|}
\hline Commerclally Llcon & In Sttu Leach I \\
\hline In Production & Not Produping" \\
\hline D & $\square$ \\
\hline
\end{tabular}

Not Pr fueing as of Dacembar 31.1908

6. Pathi... Jer Mines, North Butte - Ruth

7. Rlo Algom Mining, Smlth Ranch

8. COGEMA Mining, West Colo

9. Uranlum Resources, Roslta

10. Uranlum Resources, KIngoville Dome

11. Everest Exploration, Hobson

\footnotetext{
- Projects on standby or commercial ctart-up pending.

bMajor areas containing reserves that are amenablo to in sltu leaching at fonward costs of $\$ 30$ per pound $u_{3} O_{3}$ (\$80 per kilogram U) or loces.

Sources: Based on U.S. Department of Energy, Grand Junction Project Otfice (GJPO), National Uranium Rosource Evaluation, Interm Report (June 1979) Figure 3.2; GJPO data files; Energy Information Administration, Form ElA-858, "Uranium Industry Annual Survey" (1993); and site vialta by staff of the Analyals and Systems Division, Office of Coal, Nuclear, Electilc and Altemate Fuels.
} 
increased partnerships and joint ventures. The companies currently active in the United States have one or more of the following strengths: low cost reserves, exploration and mining expertise, favorable long-term sales contracts or market share, and overall financial strength.

\section{Figure FE2. Historical Uranium and Oll Spot Market Prices, 1970-1993}

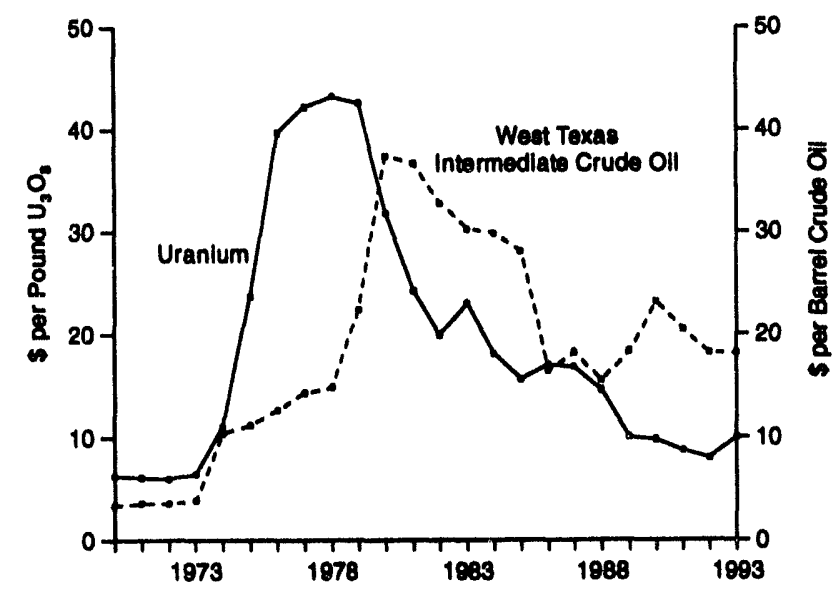

Note: Prices are in nominal dollars.

Sources: Uranium-Annual average exchange values: NUEXCO Roviow, January 1984, p. 30; Oll-Annual average Weat Texas Intermedlate Crude OIl, Oll and Cas Joumal Database, 1894.

The consolidation in ownership of the U.S. uranium industry arose as oil, metal mining, and nuclear service companies headquartered in the United States left the industry to concentrate on their core businesses. Companies that divested uranium ISL holdings included Conoco, Exxon, Kerr-McGee, Mobil, Phelps Dodge, Tenneco, and Westinghouse. The exit of oil companies was hastened by a collapse in petroleum market prices that followed a trend similar to that of uranium prices (Figure FE2). At the end of 1988, almost 90 percent of the commercially licensed ISL production capacity in the United States was owned by two independent uranium mining companies and one wholly owned subsidiary of a domestic electric power utility (Figure FE3).

Domestic ownership of the U.S. uranium industry has decreased over the past 5 years. As uranium spotmarket prices declined and more favorable long-term supply contracts expired, domestic uranium firms were less able to rely on funds from operations to finance capital expenditures or pay interest on loans. New loans became difficult to secure as potential lenders viewed uranium as an increasingly risky business. As a result, joint ventures and partnerships became the principal means of financing ISL projects in the United States. Everest Exploration, for example, sold in two stages all but a token share of its interest in Highland (Converse County Mining Venture) to foreign-owned utilities. ${ }^{6}$ Aided by declining uranium prices and abundant sources of reliable supply, U.S. nuclear power plant operators became less concerned with supply risks. As a consequence, domestic electric utility ownership of ISL production capacity in the United States ended when Malapai Resources was purchased in 1990 by Electricite de France, a foreign government-owned electric power utility.

As of March 31, 1994, 40 percent of the commercially licensed ISL production capacity in the United States was owned by three domestic firms (Figure FE3). A detailed listing of company ownership is presented in Table FE2. Everest Exploration is the last wholly independent domestic uranium mining company with interests in ISL production facilities in the United States. In addition to a small share in Highland, Everest owns the Hobson plant. Uranium Resources, Inc. (URI), an independent domestic uranium mining company, concluded a partnership agreement with Concord in early 1994 whereby Concord acquired 52 percent of URI. Concord is a domestic-based firm with uranium production (Energy Fuels) and international trading (Nuexco) subsidiaries. The Concord/URI partnership includes the Kingsvilie Dome and Rosita ISL plants, formerly wholly owned by URI. Ferret Partners, comprised of Ferret Exploration, Inc. and First Holding Co., has a small share in Ferret Exploration Company of Nebraska, the operator of Crow Butte.

Foreign entry into U.S. ISL mining began in the 1980's with investments primarily in less risky advanced-stage projects. At the end of 1988, for example, foreign firms, through investments in Highland and West Cole, owned 11 percent of the commercially licensed ISL production capacity in the United States (Figure FE3). Investments in both properties were made in 1987 after successful pilot tests were completed by domestic firms. Foreign-owned subsidiaries later became more involved

COGEMA, Inc., a foreign government-owned integrated nuclear fuel cycle company, has subsequently acquired 25 percent of Highland. 
Figure FE3. Ownership of Uranium In Situ Leach Production Capacity in the United States, December 31, 1988 and March 31, 1994

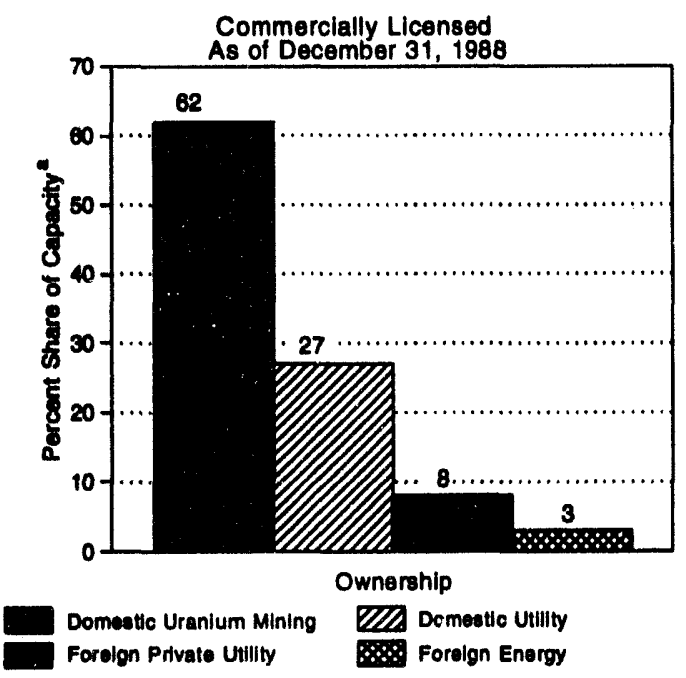

Share of total rated (nameplate) capacity for all operating and inactlve (on standby) plants on the spectifed date.

bovernment companies are those companies that are more than 50 -percent government owned.

Sources: Energy Information Administration, Form EIA-858, "Uranium Industry Arnual Survey" (1983); and uranium industry files. in exploration and development activities after acquiring expertise in operating ISL projects.

As of March 31, 1994, the remaining 60 percent of the commercially licensed ISL production capacity was owned by the U.S. subsidiaries of foreign firms (Figure FE3). Three foreign mining companies, Cameco, Rio Algom, and Uranerz, own about 13 percent of ISL capacity. Cameco and Uranerz are among the world's largest uranium producers with most of their production coming from outside the United States. In 1993, Uranerz extended its ownership in Crow Butte to a majority share. Cameco, a government-affiliated company in the process of full privatization, entered the U.S. uranium industry in early 1994 when it purchased a significant minority share in Crow Butte held by Imperial Metals. Rio Algom, a diversified mining company with historical uranium production, acquired the Smith Ranch ISL project along with the rest of KerrMcGee's uranium assets in 1989.

Foreign government-owned firms, ${ }^{8}$ consisting of four electric power utilities and COGEMA, own 47 percent of U.S. ISL production capacity. The electric power utilities are located in France (Electricite de France), Korea (Korean Electric Power Company), and the United Kingdom (Nuclear Electric and Scottish Nuclear). Electricite de France (EDF) wholly owns the title to Malapai Resources, including the Christensen Ranch, Irigaray, and Holiday-El Mesquite ISL properties. EDF and COGEMA, however, are joint partners in the Malapai properties for which COGEMA earns a 71percent interest as operator. Korea Electric Power Company owns a share of Crow Butte as a participant in Ferret Exploration Company of Nebraska. Power Resources, a wholly owned subsidiary of Nuclear Electric and Scottish Nuclear, is the operator of Highland through its majority interest in the Converse County Mining Venture. COGEMA is one of the world's largest uranium producers, as well as a provider of integrated nuclear fuel cycle services. Besides its joint venture with EDF, COGEMA owns all of West Cole and North Butte-Ruth and a minority interest in Highland through the Converse County Mining Venture with Power Resources.

The U.S. uranium industry has continued to receive investments despite having been declared non-viable by

\footnotetext{
'Cameco is considered to be government-affiliated since the Saskatchewan Provincial and Canadian Pederal governments hold minority interests in the company. The public currently owns just over 50 percent of Cameco. The schedule of privatization has been delayed due to the depressed uranium market.

"Government-owned" is applied to those companies in which the share of government ownership exceeds 50 percent.
} 
Table FE2. Ownership in Uranium In Situ Leach Projects Commerclally Llceneed in the United States, as of March 31, 9994

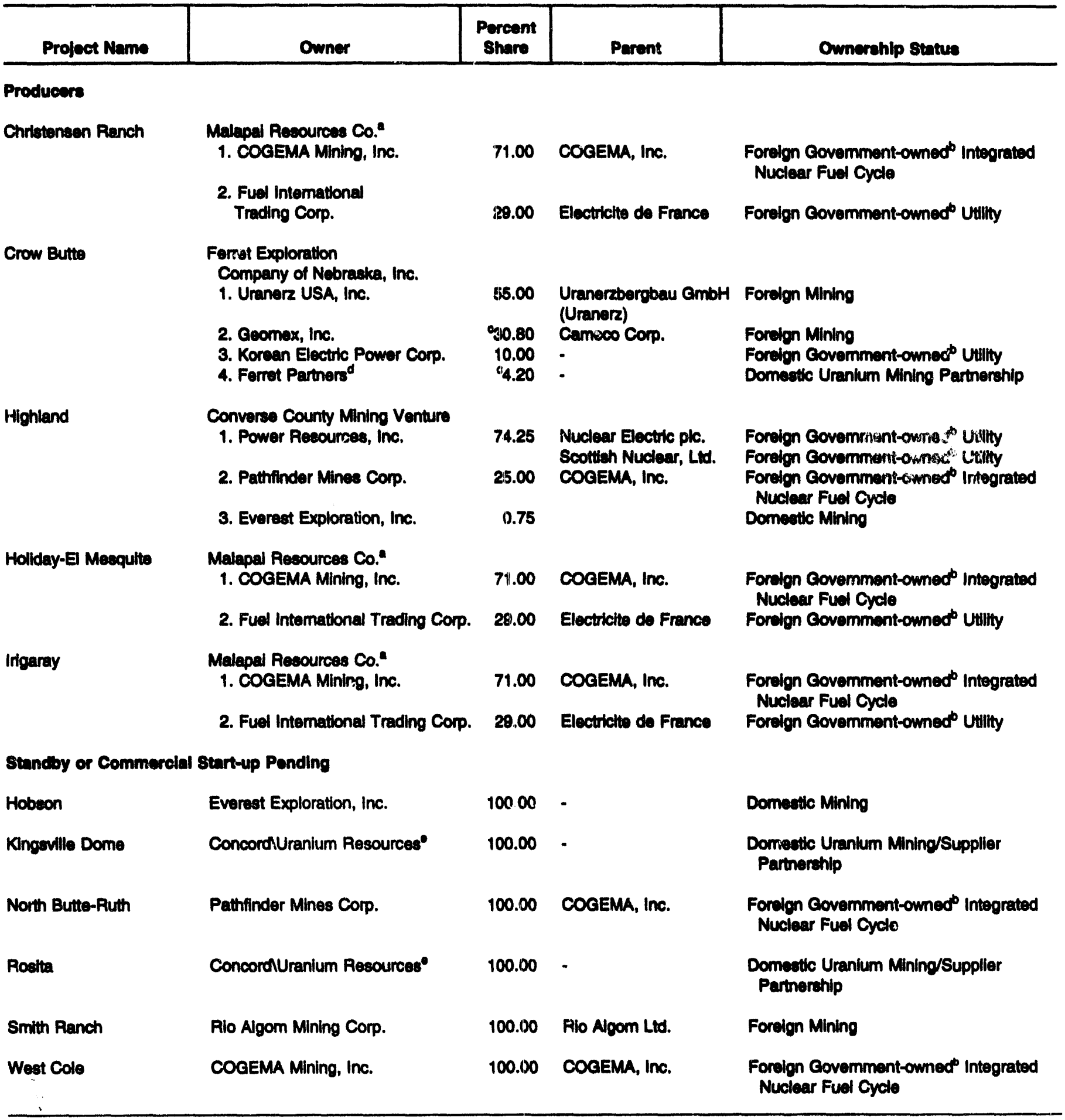

\footnotetext{
Malapal Resources is 100 percent owned by Electrictio de France (EDF). CCIOEMA Mining operates the Malapal properties under a joint partichation agreement whin EDF whereby COCEMA recolves a 71-percent share of uranlum concentrale production.

bevermment-owned" th applled to those companles in which the share of gorrernment owmerchip exceceds 80 percent.

"Share of ownership is rounded to two decimal places.

Ferrot Partners b comprised of Ferret Exploration, Inc. and Firat Holding Co. Wikch is in tum afilliated with Geomex, Inc. This arrangement efliectively gives Geomex, Inc. a 35-percent controllerehto in Crow Butte.

Urantum Resources, Inc. (UPI) concluded a partnorehip agreement with Concord in earty 1894 whereby Concord acquired 52 percent of URI.

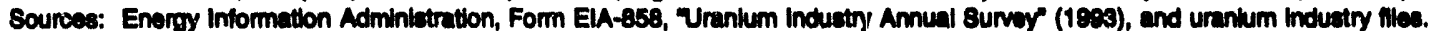


the Secretary of the U.S. Department of Energy every year since 1984. These investments made during a depressed uranium market suggest that the participants have a long-term commitment to the domestic uranium business. Foreign investment during the 1980's and early 1590's was based on (1) securing diversified sources of reliable supply, (2) acquiring existing projects at costs lower than the cost to find and develop similar production capacity, and (3) avoiding the risk of restrictions on uranium imports into the United States.

More recent decisions by both domestic and foreign firms to invest in U.S. ISL projects were based on new criteria. Cameco, for example, weighed its decision to purchase a share of Crow Butte in 1994 on a desire to broaden its exposure to ISL mining technology for worldwide application, especially in the Commonwealth of Independent States (CIS) which has significant deposits suitable for ISL mining. ${ }^{10}$

In March 1994, the Amendment to the Agreement Suspending the Antidumping Investigation on Uranium was signed between the U.S. Department of Commerce and the Russian Federation's Ministry Atomic Energy. This agreement allows Russia to export specified quantities of newly produced uranium to the United States as long as it is matched by similar levels of new U.S. production." Cameco, COGEMA Concord, and Uranerz are participating in various uranium ventures with CIS countries and presumably could benefit by positioning themselves in both the United States and the CIS.

\section{Geology of ISL Deposits}

Uranium deposits amenable to ISL mining occur in sandstones with sufficient permeability' to allow the flow of groundwater. These deposits are often described as "sandstone-hosted." The sandstone-hosted category includes uranium deposits in unconsolidated sands. Uranium is also found in other sedimentary rocks interbedded with sandstones such as mudstones and conglomerates. The host sediments were deposited in both river (Nebraska, New Mexico, Texas, and Wyoming) and mixed river and shallow marine (Texas) paleoenvironments.

Sandstone-hosted uranium deposits occur as two principal forms: (1) "roll fronts" and (2) "tabular bodies." While both forms may occur together, most deposits are characterized by a single dominant form. Roll fronts are typically found in northwest Nebraska, the Powder River and other basins of Wyoming, the Texas Gulf Coast, and to a lesser degree in the Grants mineral belt of Now Mexico. In cross section, roll fronts appear as C-shaped folds cutting across sedimentary layers with limbs that are generally parallel to layers. Higher grade uranium ore typically occurs in the folded portion of the roll fronts. The tabular form is more characteristic of uranium mineralization in the Grants mineral belt of New Mexico. Tabular ore bodies lie parallel to sedimentary bedding.

Sandstone-hosted uranium deposits lie along roughly linear trends. Some of the larger trends exceed 5 miles (8 kllometers) in length and 2,000 feet (610 meters) in width. The extent of ore-grade mineralization, however, can be irregular and discontinuous given the sinuous and braided nature of the host river sediments. Individual roll fronts and tabular bodies are usually 3 to 15 feet (1 to 5 meters) thick. Roll fronts often occur in multiple horizons, commonly referred to as vertically stacked ore bodies.

In general, sandstone-hosted uranium deposits were formed as uranium was precipitated from oxidizing groundwater where a reducing environment was encountered in the host sediments. ${ }^{2}$ Concentrations of organic materials, such as woody fragments, provided the reducing environment. Impermeable shales within the sedimentary sequence served an important role in confining and concentrating ore-bearing solutions.

'Permeablity is a measure of the sediment's capablity to trankmit fluid.

'An oxddation-reduction reaction takes place as electrons are tranaterned between molecules in a reduced state (negattve electrical charge) and molecules in an oxdized etate (positive electrical charge). This chemical reaction results in the precipltation of uranium compounds that are insolubte in the reducing envionment.

'NuclearFuel, Fobruary 28, 1994. p. 16, published by McGraw-Hill, Inc., New York, NY.

Bnery Information Administration, "The Uranium Industry of the Commonwedth of Independent States," in Uranium Industry Annual 1991, DOB/BIA0478(91) (Wathington, DC, October 1992), p. 10. The Commonwealth of Independent States is an aseociation of 12 former Soviet republics.

"The suppenaion agreement prior to amendment prohibited imports of uranium from Ruala until a certain martet-based price threshold was reached as devermined by the U.S. Department of Commerce. 


\section{Reserves}

The Energy Information Administration estimated U.S. uranium reserves ${ }^{12}$ amenable to ISL mining as of December 31,1993 , at 122 million pounds $\mathrm{U}_{3} \mathrm{O}_{8}(47$ thousand metric tons $U$ ) at forward costs of up to $\$ 30$ per pound $\mathrm{U}_{3} \mathrm{O}_{8}(\$ 80$ per kilogram $\mathrm{U}) .^{13}$ These reserves are found primarily in Nebraska, New Mexico, Texas, and Wyoming (Figure FE1). Additional ISL reserves of 179 million pounds $\mathrm{U}_{3} \mathrm{O}_{8}$ are estimated at forward costs between $\$ 30$ and $\$ 100$ per pound $\mathrm{U}_{3} \mathrm{O}_{8}$. Forward costs are based on the operating and capital costs (in current dollars) yet to be incurred in producing uranium from known deposits. Income tax, profit, interest, and previously incurred (sunk) costs are not considered in determining forward costs. The EIA considers current mining and processing technology and regulations in its economic assessments.

ISL reserves comprise 42 percent of total U.S. reserves in the \$30-per-pound $\mathrm{U}_{3} \mathrm{O}_{8}$ cost category. The average grade of ISL reserves is 0.13 percent $\mathrm{U}_{3} \mathrm{O}_{8}$, compared with 0.14 and 0.27 percent $\mathrm{U}_{3} \mathrm{O}_{8}$, respectively, for open pit and underground reserves. ${ }^{14}$ The lower average grade of ISL reserves reflects the feasibility of using ISL mining to produce from certain lower grade ores that could not be economically recovered by conventional inethods.

\section{ISL Mining Process}

ISL mining consists of the extraction of uranium from the host sandstone by chemical solutions and the recovery of uranium at the surface (Figure FE4). It is then processed into a marketable concentrate. The typical ISL mining facility consists of a number of wellfields and a central processing plant. Certain larger projects operate more efficiently by recoverirg uranium at one or more satellite plants and trucking the resulting uranium-rich slurry to a central plant for final processing. The production site also contains evaporation ponds used to treat waste water. Other than in

\section{Characteristics of Uranium Ore Zones Amenable to ISL Mining}

ISL mining involves the movement of groundwater to carry both the leaching agents and the liberated uranium. Therefore, the feasibility of such a process critically depends on the certain characteristics of the uranium ore zone. Many of the same characteristics that were important in ore deposition also aid in the ISL mining processes. For uranium to be economically recoverable with present technology, the ore must occur in permeable sandstones that lie below the water table. These sandstones are called aquifers because they conduct groundwater and can produce economically significant quantities of groundwater through wells and springs. A high degree of permeability allows for solutions to efficiently pass through the ore zone. Permeability declines as unconsolidated sediments are compacted in the rock-forming process and pore spaces become filled with intergranular cements or silt and clay.

The intersection of the aquifer by a well acts as a point of least resistance, inducing groundwater to flow toward the well. Wells are arranged to maximize groundwater flow in the vicinity of the orebody. Besides aiding in the recovery of uranium, high flow rates promote efficient removal of contaminated groundwater from the aquifer during restoration.

Water in the equifer is under hydrostatic pressure' due to the weight of the overlying column of water. Pressure is increased wherever the flow of groundwater moving down dipping sandstone beds is confined by impermeable shale beds. The ISL process is further aided if the aquifer is under enough pressure to produce water on the surface through a well or spring. This type of flow is called artesian and reduces the effort it takes to mechanically pump water to the surface. Impermeable beds also serve to confine the leaching solution in the ore zone. Optimal flow cannot be achieved if groundwater is allowed to migrate vertically or horizontally outside the production zone. Groundwater migration, also known as excursions, can be induced through springs, faults, unplugged or poorly cased wells, underground mine workings, or neighboring pumping activities.

'Hydrostatic pressure is the pressure exerted by the water at any given point in a bocty of water.

\footnotetext{
12Reserves are generally equivalent to two other widely used rewource categories: (1) "Ressonably Assured Resources" used by the Organization for Economic Cooperation and Development's Nuclear Bnergy Agency and the Internatioaal Atomic Energy Agency, and (2) "Measured and Indicated Reserves" used by the U.S. Bureau of Mines and the U.S. Geological Survey.

${ }^{13}$ Bnergy Information Administration, Uranium Industry Annual 1993, DOE/EIA-0478(93) (Washington, DC, September 1994), Table 11.

14 Ibid.
} 
constructing roads and evaporation ponds, little of the ground surface is disturbed during ISL mining.

ISL wellfields are constructed after the ore deposit has been delineated and the hydrological characteristics of the aquifer are determined. The pattern of each wellfield is arranged to optimize the recovery of uranium. A five-spot pattern is commonly used in the United States. This pattern resembles a grid with an injection well at each comer and a production well in the center. The spacing between the injection wells and production wells usually ranges between 50 and 100 feet (15 and 30 meters) (Figure FE5). After the completion of drilling, wells are cased with PVC pipe ${ }^{15}$ and the space between the casing and formation is sealed with cement. This arrangement prevents vertical migration of contaminated groundwater from the producing zone into adjacent aquifers. A reaming tool is used to remove the casing and cement at the production horizon to allow flow between the well and the ore zone. Current ISL production comes from wells drilled between 300 and 850 feet (90 and 260 meters) deep. Monitor wells are sited peripheral to the wellfield to ensure that contaminated water does not move outside the mining area.

Dissolved oxygen is injected into the ore zone to oxidize the uranium minerals, thereby changing them into a form that can be extracted through leaching and pumped in solution to the surface. Uranium is leached by introducing chemicals known as "lixiviants." The choice of lixiviants is influenced by the composition of the urarium minerals, including coatings by other minerals. Alkaline lixiviants, ${ }^{16}$ such as the combination of sodium bicarbonate and carbon dioxide, are used exclusively in the United States. Earlier research projects experimented with other types of lixiviants including sulfuric acid. While more effective in certain situations, sulfuric acid is no longer used because it rendered the aquifers more difficult to restore after mining.

The production life of an individual ISL wellfield is usually less than 3 years. Most of the uranium is recovered during the first 6 months of the wellfield's operation. Production efficiencies are expressed as the recovery rate or the percent of uranium recovered from

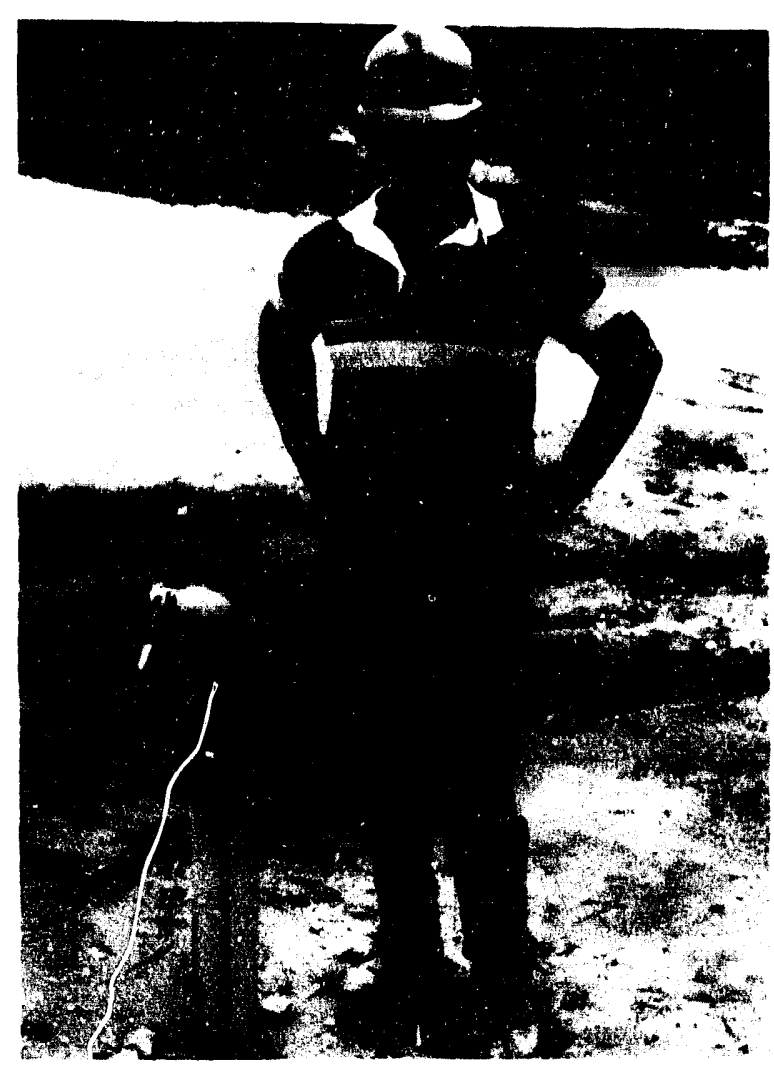

Abovi-ground portion of a typical uranium in situ leach production woll. The well is approximately 3 feet (1 metel) high. To protect against severe winter weather, wells are covered with boxes like the one shown above the arm of the engineer at the upper right hand corner of the photograph.

the estimated geologic resource ${ }^{17}$ over the life of production. Recovery rates vary among ISL mining projects. The most successful projects have achieved overall recovery of around 80 percent. Within successful projects, however, some individual wellfields may experience lower recovery due to localized groundwater migration.

Over time, production flows decrease as clay and silt become trapped in the permeable sediments in the vicinity of the well. Enhancement techniques, such as "workovers" and "well reversals," are used to temporarily increase the flow of groundwater. Workovers

\footnotetext{
${ }^{15}$ PVC denotes polyvinyl chloride, a form of plastic.

${ }^{16}$ Alicaline lixivients have $\mathrm{pH}$ values greater than 7.0 compared to acidic lixiviants with pH values less than 7.0 . A chemical solution with a pH of 7.0 is considered neutral (the pH of pure water).

${ }^{17}$ Geologic resource differs from reserve in that mining and processing losses are not considered.
} 


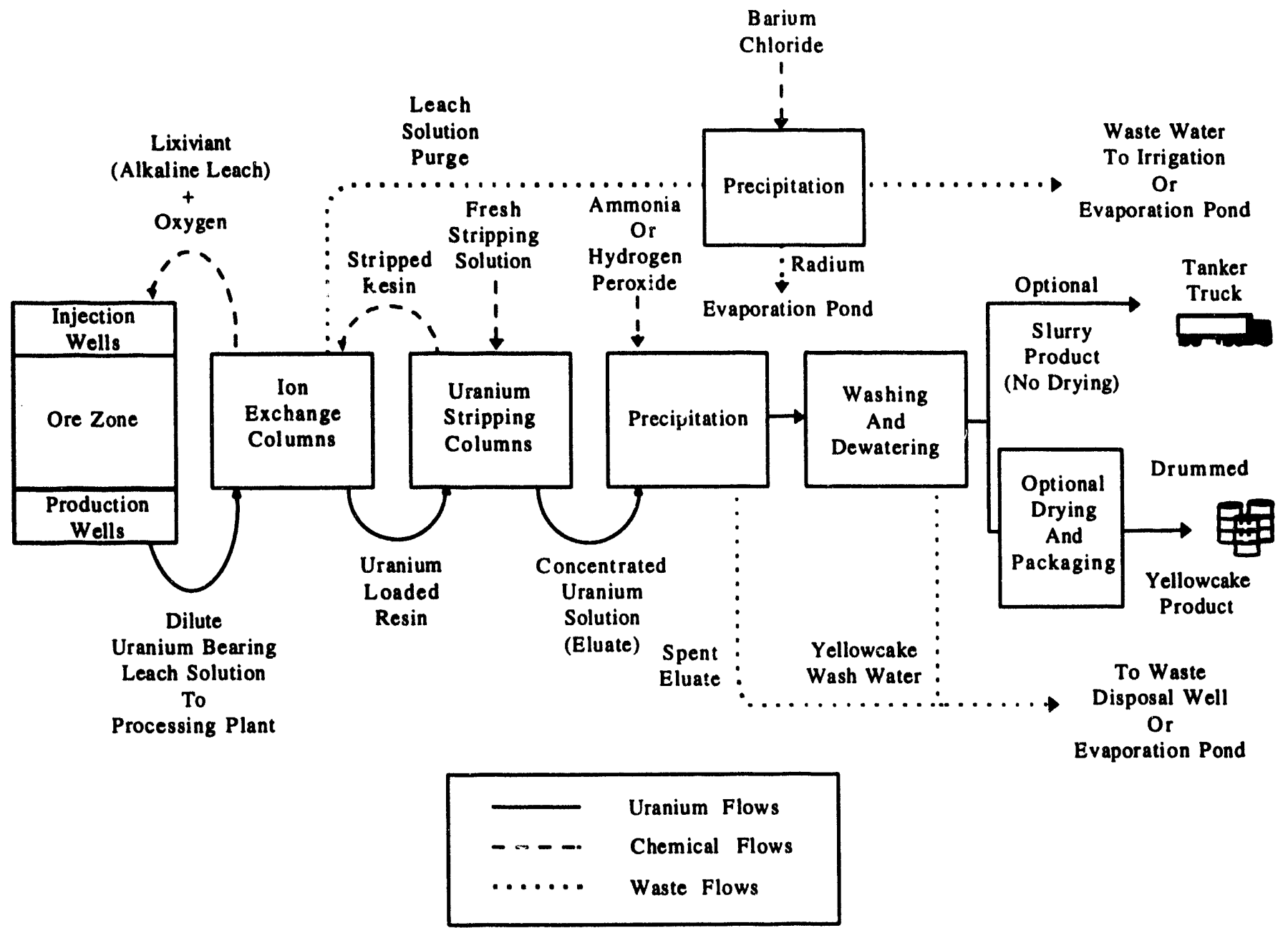

Source: Modified from Power Resources, Inc., 1991, company brochure.

employ a jet nozzle at the end of a drill pipe to inject solution under high pressure. The ore zone is swabbed by moving the jet nozzle up and down the intersecting well. Reversals employ the temporary switching of injection and production wells to induce changes in groundwater flow patterns.

Groundwater is circulated between the ore zone and the uranium processing plant in a closed system (Figure FE4). To maintain efficient flow of fluids between the ore zone and the surface, about 1 to 3 percent of the leach solution by volume is purged from circulation prior to reinjection into the aquifer. The flows from a series of wellfield patterns are controlled by valves and manifolds. The output from each production well flows in PVC pipes to the manifolds where it is combined with the output from other wells. From the manifolds, uranium-charged leach solution is sent through a larger diameter pipe to the ion exchange columns at the processing facility. The return flow of solution, depleted of uranium, is diverted through the manifolds to the injection wells.

Uranium is recovered from the uranium-charged leach solution at the processing facility in ion exchange columns. In this process, uranium is adsorbed by resin 
Figure FE5. Generalized Cross Section of a Portion of a Typical Uranium In Situ Leach Wellfield

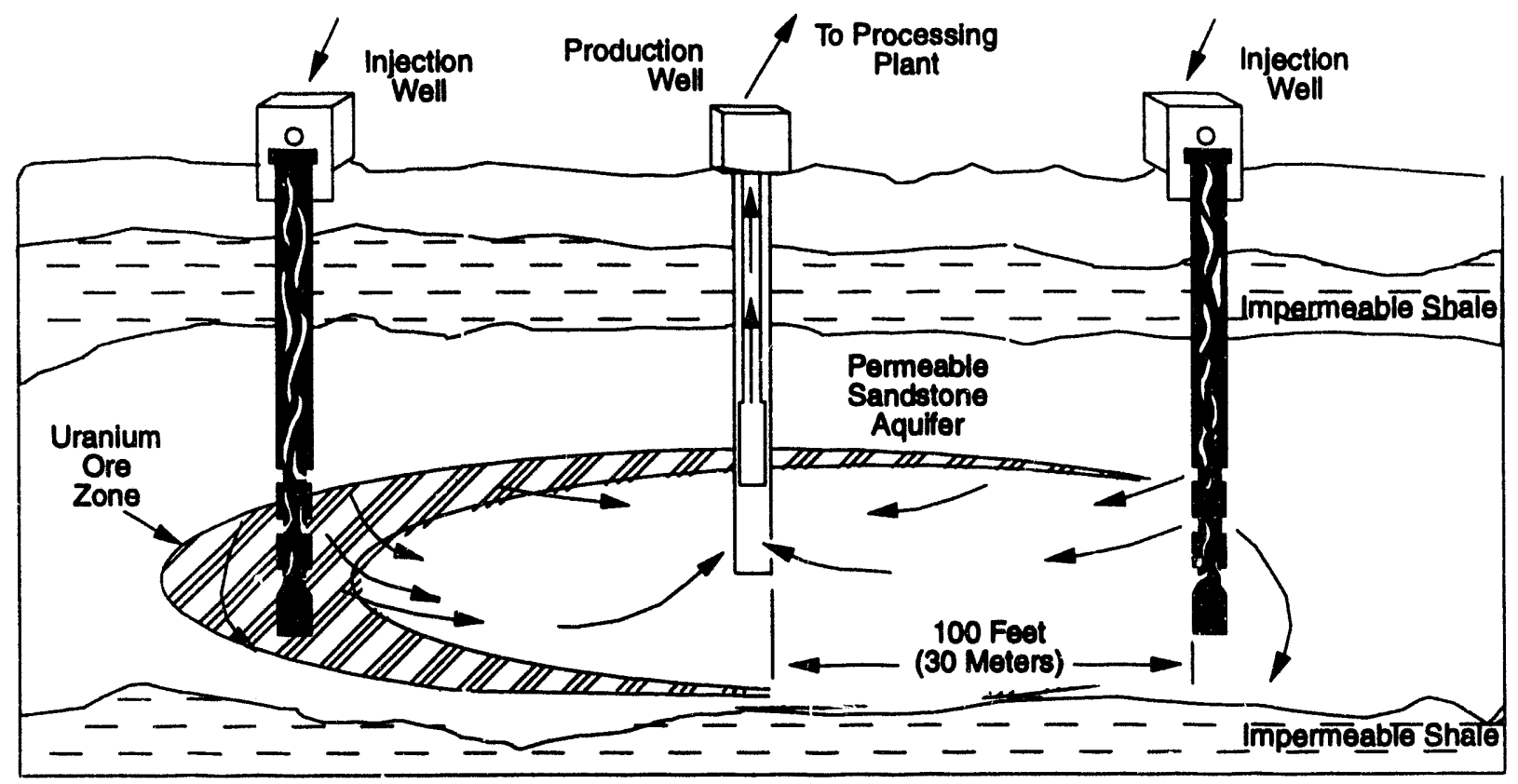

Note: Not drawn to scale.

Source: Energy Information Administration, Otices of Coal, Nuclear, Electric and Attemato Fuels.

made up of small plastic beads. The ion exchange recovery can be carried out in the central processing plant or separately in a satellite facility from which the loaded resin is trucked to the central plant for stripping and further processing. The stripping process, or elution, yields a uranium-rich eluate from the loaded resin, usually by adding sodium chloride and sodium bicarbonate. Once stripped of uranium, the resin can be reused in the ion exchange columns. Uranium is precipitated from the eluate by adding either ammonia or hydrogen peroxide and changing the $\mathrm{pH}$ of the solution. Depending on the chemical treatment, the precipitate is either ammonium diuranate or uranyl peroxide, both called "yellowcake."

The yellowcake is washed and dewatered to form a slurry. At some plants, the slurry is shipped by tanker truck either to another processing plant for drying and packaging or directly to a uranium conversion facility. ${ }^{18}$ Other plants have their own drying and pack- aging circuit. With increased heating, the final color of yellowcake changes from yellow to dark brown or black. The heating drives off most of the volatile impurities, leaving a uranium concentrate product composed of various oxides of uranium popularly called $\mathrm{U}_{3} \mathrm{O}_{8}$. The product is shipped in sealed metal drums to customers.

\section{Waste Water Treatment}

Prior to disposal, the waste water from purging the leach solution (Figure FE4) must be treated to remove radium $\left(\mathrm{Ra}^{226}\right)$ and other contaminants such as arsenic, iron, molybdenum, selenium, and vanadium. These contaminants are mobilized along with uranium during the leaching of the ore zone. Barium chloride is added to the waste water to precipitate radium. The ensuing sludge is disposed of in plastic-lined evaporation ponds. Heavy metals are also settled out in evaporation ponds.

\footnotetext{
${ }^{18}$ Conversion is the process of changing natural uranium oxide $\left(\mathrm{U}_{3} \mathrm{O}_{4}\right)$ into uranium hexafluoride $\left(\mathrm{UF}_{6}\right)$, a feedstock required for enriching uranium into fuel for nuclear power plants.
} 


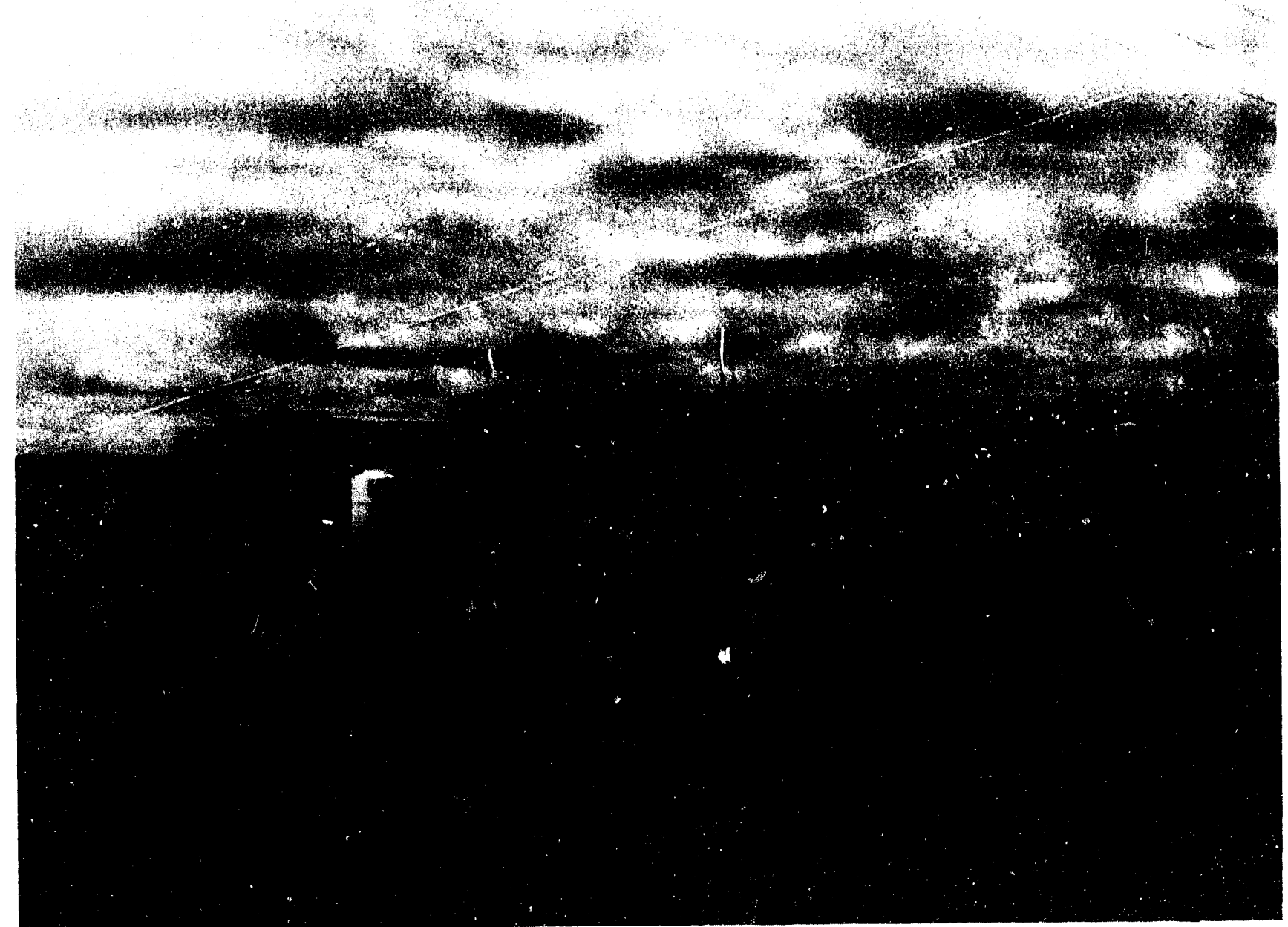

A central processing plant for recovering uranium and producing marketable concentrate from uranium-bearing solutions obtained through in situ leach mining.

After mining has been completed, the sludge and the plastic liners are removed and transported to sites licensed for disposal of low-level radioactive waste. Some ISL operators have found it cost effective to dispose through irrigation treated waste water that meets environmental quality standards.

The spent eluate and waste from the washing circuit are disposed in evaporation ponds or deep aquifers (Figure FE4). To qualify for waste disposal, an aquifer must be permitted for such use. Such aquifers naturally contain water of insufficient quality for agricultural or residential uses and are sufficiently confined to prevent migration of contaminated water into neighboring aquifers.

\section{Groundwater Restoration}

After ISL mining is completed, the quality of the remaining groundwater must be restored to a baseline standard determined before the start of operation. Wellfield restoration often takes place concurrent with mining as additional wellfield sites are put into production. Restoration of the aquifer is accomplished by using a number of methods including groundwater sweep and the reinjection of treated mine water. The process generally takes several years to gradually flush dissolved contaminants out of the aquifer.

A groundwater sweep draws uncontaminated native groundwater into the mined area as contaminated water 
is pumped out of the aquifer. The contaminated water is disposed of in evaporating ponds, deep wells, or is transferred for use in new mining areas. After being treated to remove contaminants, water can be used for irrigating crops. Since large volumes of groundwater must be pumped from the aquifer during restoration, groundwater sweeps are usually augmented by the reinjection of treated water.

The restoration process requires that water be treated for all contaminants before it can be reinjected into the aquifer. The uranium prosessing plant is used to recover uranium during restoration, although the groundwater contains much less uranium than during the production phase. Radium is removed from the solution as described in the treatment of purged leach solutions. Other contaminants are left to settle in evaporation pond i or are extracted through reverse osmosis. Reverse osmiusis is a process in which solutions under pressure: are forced through membranes. Brines containing the contaminants are trapped on the high-pressure side of the membrane while clean water passes through the membrane. The brines are disposed of in evaporating ponds or in deep disposal wells.

\section{Radlation Safeguards}

ISL mining facilities are required to have an on-site radiation officer. The radiation officer is responsible for training employees and performing radiation checks at the facility. Safety inspections for individual employees include (1) monitoring employees for alpha radiation each time they leave the processing plant and (2) quarterly evaluation of personal dosimeters to evaluate exposure to gamma rays. Routine safety checks are made in and around facilities for radon, radon daughters, airborne uranium particles, and alpha and gamma radiation. ${ }^{19}$

\section{Regulatory Approval Process}

Uranium production is highly regulated in the United States. Permits and approvals for constructing and operating uranium ISL facilities are required by Federal, State, and local governments. For example, the necessary approvals required in Wyoming are summarized in Table FE3.
The U.S. Nuclear Regulatory Commission (NRC) is the principal Federal agency involved in regulating ISL uranium production. The U.S. Mine Safety and Health Administration requires operators to register mines and submit their safety training plans for approval. Where ISL projects are planned for lands administered by the Bureau of Land Management or the Forest Service, approval for their development and operation must be secured from the appropriate Federal agency. Regulations for Indian Lands are administered by the individual tribal governments and the U.S. Bureau of Indian Affairs.

The U.S. Congress empowered the NRC to administer regulations issued under the Atomic Energy Act of 1954, as amended, and Titles I and II of the Uranium Mill Tailings Radiation Control Act of 1978. The environmental standards for these regulations, established by the U.S. Environmental Protection Agency (EPA), are contained in the Code of Federal Regulations, 40 CFR Part 192, "Health and Environmental Standards for Uranium and Uranium Mill Tailings." With the exception of Texas, the NRC has regulatory authority in all States with major ISL mining projects. Through an agreement between the State and Federal governments, Texas administers its own regulatory programs with standards at least equal to those established by the EPA.

The NRC grants approval to operate an ISL uranium project through the issuance of a source material license. Approval requires the applicant to demonstrate the ability to comply with environmental protection and radiological safety standards. The NRC evaluates technical information provided by the applicant including local and regional environmental impact assessments, demographic studies, operational procedures, radiological safety program, environmental monitoring, and site restoration program. The operator is also required to post a surety bond to assure that sufficient funds will be available for site decommissioning. ${ }^{20}$ If no serious problems are encountered, approval is usually granted in about 24 months.

In addition to the NRC (the exception for Texas was previously noted), the prospective operator is regulated

\footnotetext{
${ }^{19} \mathrm{Rad}$ ( $\left.\mathrm{(Ra} \mathrm{R}^{223}\right)$ is formed during the radioactive decay of the naturally occurring isotope of uranium, $\mathrm{U}^{238}$. In turn, radon decays into its "daughters," unstable isotopes of polonium, bismuth, and lead. Radon and its daughters can be carried by air and water. During the decay process, energy is released in the form of alpha and betu particles and gamma rays.

${ }^{20}$ Decommissioning is a general term applied to the process of closing a nuclear facility. The decommissioning of ISL facilities involves dismantling wellfields and processing facilities, removing materials contaminated by radiation, reclaiming evaporation ponds, and restoring groundwater.
} 
Table FE3. Regulatory Approvals Required for Commercial Licensing of in Situ Leach Mining Projects in Wyoming, as of March 31, 1994

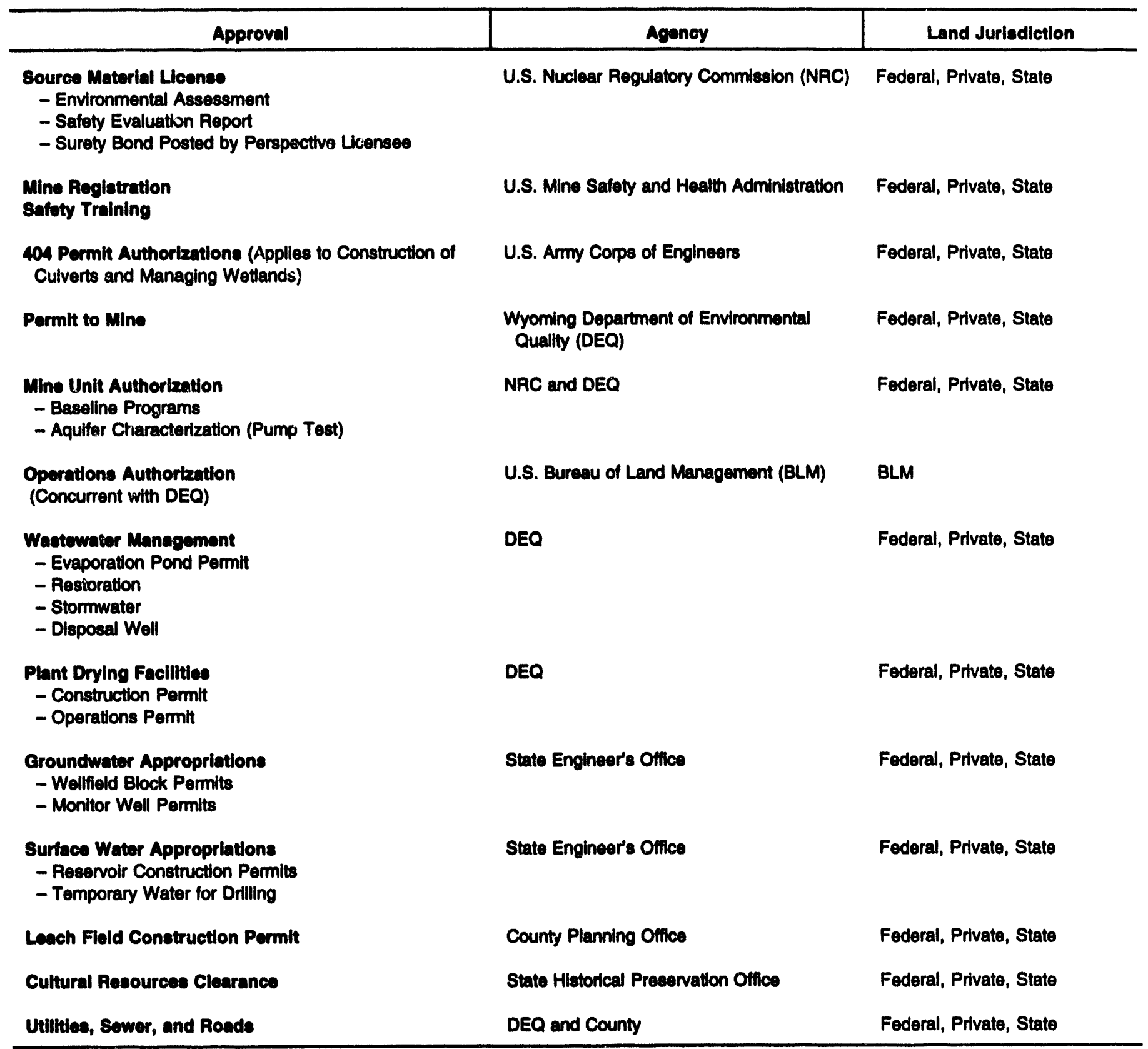

Source: Whchers, Donna, Pathfinder Mines Corporation, 1894, Wyoming ISL Projects: Summary of Approvals Necessary for Inltiation of Commerclal Operations," unpubllshed tables.

by State and local governments. Environmental agencies, such as the Wyoming Department of Environmental Quality and the Texas Natural Resources Conservation Commission, issue mining permits and regulate waste water management. Approval to appropriate groundwater for industrial use typically comes from the State Engineer's Office. County governments are involved in granting wellfield construction permits in some States.

Certain State permit applications are similar to those required by the NRC. This duplication adds to the cost of regulation and may delay the start of operation. Streamlining of regulations has been implemented by 


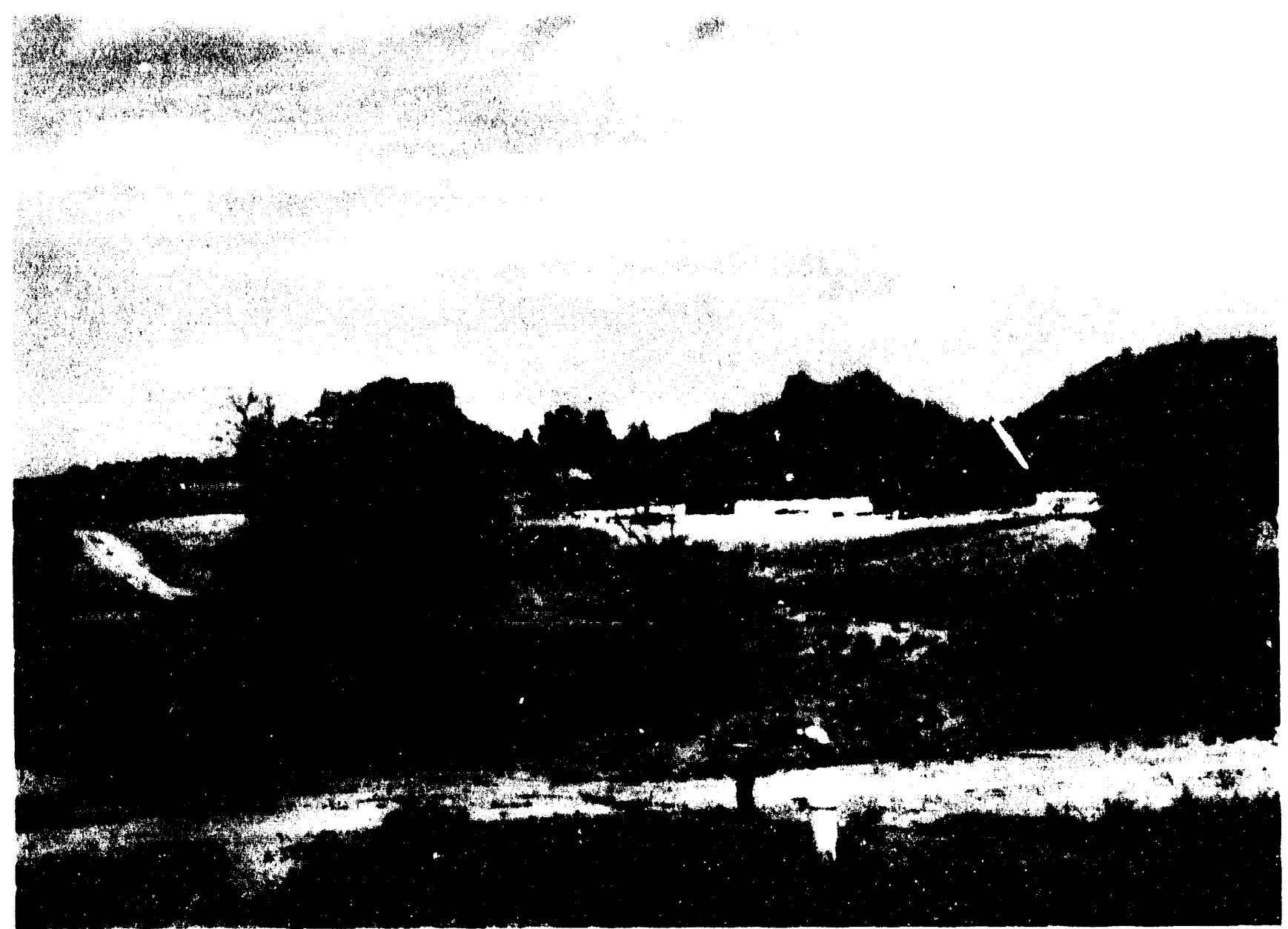

This uranlum in situ leach wellfleld in northwestem Nebraska has little impact on the agrarian landscape. Well in the foreground is approximately 3 feet (1 meter) high.

some States. Wyoming, for example, no longer requires on-site pilot demonstrations if prospective projects are shown to have characteristics similar to successful operations.

\section{Economic Considerations of ISL Mining}

ISL mining of selected ore deposits is currently the lowest cost method for producing uranium in the United States. The recent level of spot-market prices of around $\$ 10.00$ per pound $\mathrm{U}_{3} \mathrm{O}_{8}(\$ 26.00$ per kilogram $U){ }^{21}$ however, is below the forward costs to produce uranium for all but a few ISL projects. As a consequence, pro- duction has been suspended at some facilities, and the start of new operations has been delayed. All projects would be benefitted by favorable long-term contracts with electric power utilities in which the prices exceed the current spot-market level.

A project's economic feasibility is determined through the evaluation of technical, financial, marketing, and regulatory factors. The following discussion is limited to technical factors, the physical characteristics of the uranium orebody, host aquifer, and the mining facilities. The characterization of these factors forms the basis for all subsequent determinations of whether a project can

\footnotetext{
${ }^{21}$ Spot market refers to the buying and selling of uranium that typically involves transactions for delivery within a year of contract execution. The quoted price is an approximation of monthly uranium exchange values during 1993 relative to the U.S. market in nominal dollars per pound of uranium concentrate $\left(\mathrm{U}_{3} \mathrm{O}_{1}\right.$ ). Source: NUEXCO Review, January 1994 (conversion factor: 1 pound $\mathrm{U}_{3} \mathrm{O}_{\mathrm{a}}=0.384647$ kilogram $U$ ).
} 
be economically operated and conform to regulatory standards. Some of the more important technical factors and their impact on the economic feasibility of ISL uranium mining projects are presented in Table FE4. Because technical factors are not constant for every project, the success of a particular project depends on strengths offsetting weaknesses. For example, the higher cost to complete deeper wells could be offset by the lower cost to pump groundwater under artesian flow.

Capital costs are expended on preparing the ISL site for prodv tion. Such costs include development drilling, pumping equipment, construction of wellfield and processing facilities, preparation of environmental studies, and pilot demonstrations. In contrast, operating expenses are incurred for the day-to-day operation of the mine. Mining, processing, restoration, and environmental monitoring are considered operating activities. Labor, chemicals, electricity, engineering, management, and maintenance are typical ISL operating costs.

Large continuous orebodies with higher-than-average ore grades are particularly suitable to low-cost mining.
This situation offers greater economies of scale, because all costs are spread over larger volumes of production. A substantial reduction in capital outlay may be achieved through the utilization of existing processing facilities. Uranium can be extracted at satellite facilities and the loaded resin trucked to an existing plant for final processing. When total on-site integration of processing is required, some companies have reduced plant construction costs by purchasing existing facilities at salvage value. Mining and restoration costs are strongly dependent on the geological and hydrological characteristics of the ore zone described in previous sections.

Deep orebodies require additional development drilling and well casing. While successfully demonstrated in a technical sense, ISL mining of deep orebodies is economically constrained by the operating efficiency of low-cost PVC well casing. The structural integrity of PVC casing diminishes at depths greater thin 1,000 feet (305 meters), necessitating the use of much more costly replacement materials.

Table FE4. The Impact of Technical Factors on the Economic Feasibility of Uranium In Situ Leach Mining Projects

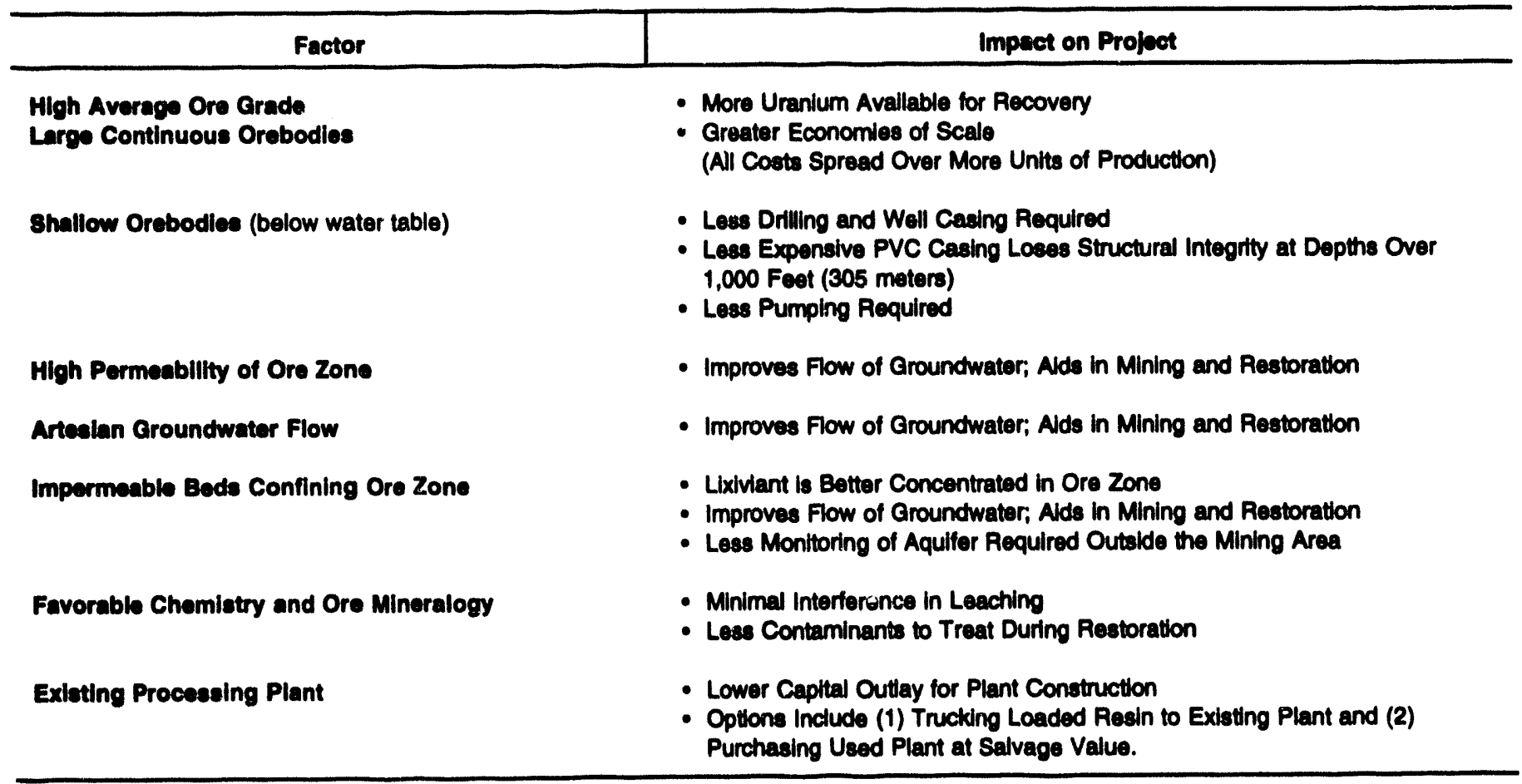

Source: Uranium Industry Flles of the Energy Information Administration, Omice of Coal, Nuclear, Electito and Artemate Fuels. 


\section{Comparison With Conventlonal Mining and Milling}

The application of the ISL technique in selected projects offers many important cost advantages over conventional mining and milling. The advantages are significant enough to offset the higher uranium recovery typically achieved by conventional methods. ISL mining does not require blasting, mechanical hauling of ore and waste rock, or crushing and grinding of ore. This translates into lower capital requirements and reduced operating and maintenance costs. The simplification of production requires fewer employees to operate and maintain ISL mining facilities.

The U.S. uranium industry realized substantial gains in labor productivity as a result of ISL mining's increased share of production. As a consequence, the annual uranium output per employee has increased from about 1.3 tons of $\mathrm{U}_{3} \mathrm{O}_{8}$ (1 metric ton $\mathrm{U}$ ) in 1980 to over 4 tons of $\mathrm{U}_{3} \mathrm{O}_{8}$ ( 3 metric tons $U$ ) in recent years. ${ }^{22}$ For comparable annual production rates, fewer people are required to operate an ISL project than are required for a conventional mining and milling project. Uranerz, for example, reports that Crow Butte produces about 500,000 pounds $\mathrm{U}_{3} \mathrm{O}_{8}$ (192 metric tons $U$ ) annually with 25 on-site employees. ${ }^{23}$ The annual production rate of Crow Butte could be increased to the nominal plant capacity of 1 million pounds $\mathrm{U}_{3} \mathrm{O}_{8}$ (385 metric tons $U$ ) with little expected increase in employees. In contrast, Pathfinder Mines employed 190 people at the now-closed Shirley Basin conventional open-pit mine and mill to produce at an annual rate of about 740,000 pounds $\mathrm{U}_{3} \mathrm{O}_{8}$ (285 metric tons $\left.\mathrm{U}\right){ }^{24}$ Expressed as annual uranium output per employee, Crow Butte's productivity rate is 10 tons of $\mathrm{U}_{3} \mathrm{O}_{8}(7.7$ metric tons $U$ ) compared to about 2 tons $\mathrm{U}_{3} \mathrm{O}_{8}$ (1.5 metric tons $U$ ) for Shirley Basin.

ISL mining has much less impact on the environment than conventional operations. Since no mill tailings or rock waste are produced, ISL operations incur lower reclamation and environmental monitoring costs. ISL mining also poses less radiation and dust exposure to employees. If enacted, proposed reductions ${ }^{25}$ in the limits of radiation exposure would significantly add to the cost of underground mining. Because of its reduced environmental impact, ISL uranium mining is expected to be more widely accepted by the public than conventional mining and milling.

\section{Summary}

In a little over 20 years, ISL mining has evolved from an experimental technology to the dominant producer of uranium in the United States. ISL mining applied to selected sandstone-hosted deposits is currently the lowest cost source of uranium production. Cost advantages are realized by larger projects that utilize existing processing facilities. Unfavorable uranium market conditions, however, have resulted in excess capacity and delays in starting new projects.

Investment continues to flow into ISL uranium mining projects, despite the U.S. uranium industry having been declared non-viable since 1984 . Currently, 60 percent of commercially licensed ISL production capacity is owned by foreign companies or their wholly owned subsidiaries. Recent acquisitions are seen as efforts by large international uranium companies to increase their exposure to ISL technology and ensure participation in regulated markets.

Uranium reserves amenable to ISL recovery are found in Nebraska, New Mexico, Texas, and Wyoming. Pending improved market conditions, any future additions to existing uranium production capacity in the United States are expected to be met through lower cost and more environmentally acceptable ISL facilities, rather than through conventional operations.

\footnotetext{
${ }^{2}$ Bnerzy Information Administradion, Uranium Industry Annual 1993, DOE/BIA-0478(93) (Wachington, DC, September 1994), derived from Tables 16 and 21.

${ }^{25}$ Catchpole, G., and Kirchner, G., "The Crow Butte ISL Project-A Case History," in Uranium In Situ Leaching, Proceedinge of a Technical Committee Meeting beld by the International Atomic Bnergy Agency in Vienna, October 5-8, 1992, IAEA-TBCDOC-720, (Vienna, September 1993 ), p. 81.

2Pathfinder Mines Corporation, 1990, Shirley Basin Mine (Company Brochuro).

${ }^{25}$ The International Commission on Radiological Protection recommenda that average annual occupational exposure limit be reduced by 60 percent.
} 
Expenditures for surface dril percent over the level for decreased both for land aco other exploration expenditure

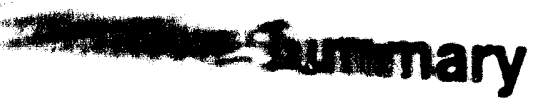

Rearves. As of the end of recoverabs a d cost of $330 \mathrm{pet}$

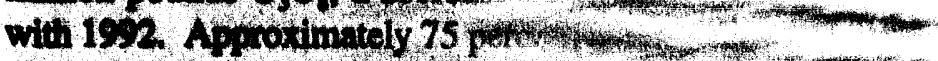
woro locited in doposits in Newhets Wyoming. The domense refledtwsty

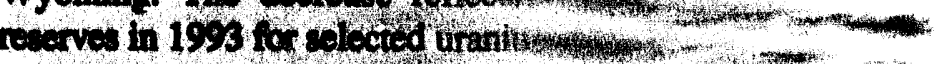
recovery costs, doplotion, and the of 1993 dodived to $932 \mathrm{~W}$. percent decline comparded witif or

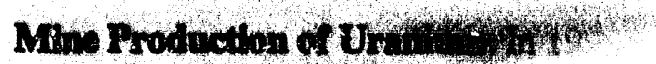

of uranium from mh s was $2.0 \mathrm{mil}$.

increace of 105 perent from the 108 .

total includes poditiotion from in w operations, aquifer rotoratios ond 1 . excludes uranium reooverted of 6 WJ mining of phosphate.

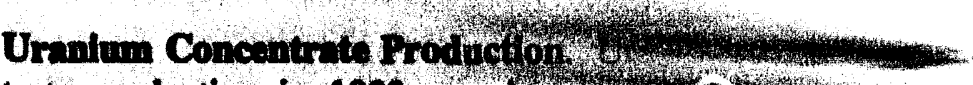
trate production in 1993 was just in w pounds $\mathrm{U}_{3} \mathrm{O}_{4}$. Of this amount, $3.0 \mathrm{H}$. percent) were produced by process iff 3 it solutiors from in sitn leachins byprot, operations, and reclamation activitus. braska, New Mexico, Texa, and Wyoming. all of the 1993 concentrate production.

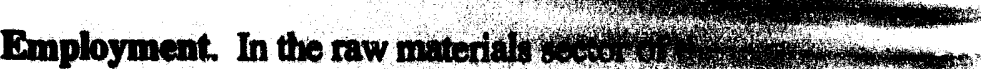
uranium indugtry, total emolojm

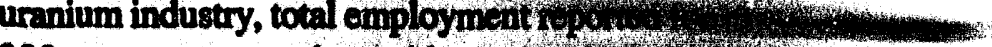

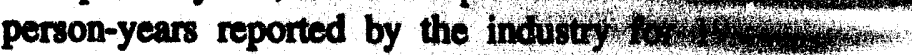
additional 491 person-years were expended in res.

work in the raw materials sector.

\section{(3) Uranium Markoting Aotivitios}

Domestic Purchase Commitments by 1993, U.S. electric utilities signed 23 unnin contracts with suppliers ${ }^{1}$ for $\mathbf{5 . 0}$ million porminta.t.

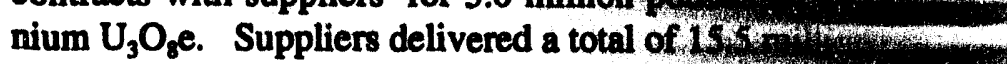

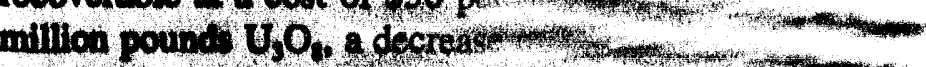
frellitis The \$50 por-pound U, O , t 380 person-years, about 44 porow 1 .

\begin{abstract}
duties were imposed on imports of mom Tajikistan or highly enriched uranium HE: Som the Ukraine. The agreements specify inces on imports of uranium that are tied to a mice of uranium in the United States. The price was determined by the Department - inmere, to be below the minimum threshold anding imports from Kazakhstan, KyrRossian Federation, and Uzbekistan into - Inued Stres.
\end{abstract}

1. - In 1993 20 million pounds $\mathrm{U}_{3} \mathrm{O}_{8} \mathrm{e}$ (equivalent), the record-high level in 1990 . Imports sypes of transactions are not included. mon prices in 1993 dropped 7 percent ane 92 level to a record-low level of $\$ 10.53$ 1 Tof. The greater portion of 1993 import wande under contracts signed prior to whe quantity-weighted average price maner. $\mathrm{X} 3$ per pound.

andes held by U.S. utilities continued 1993 reaching 80.7 million pounds of the year. This represented a drop 1 the level of stocks at the end of - Ex 50 percent below the record-high and by utilities at the end of 1984 atritine poends $\mathrm{U}_{3} \mathrm{O}_{8} \mathrm{e}$ ).

\section{naterials Activities}

Thement. Total surface drilling in 2593, consisting of exploration and 1.1 million feet in 2,020 holes. 15 meent greater than the 1992 total an 98 percent less than in 1978, Eryon drilling accounted for 20 and development drilling acThe amount of land held by acres at the

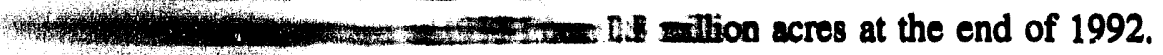
the thelopment expenditures in 1993

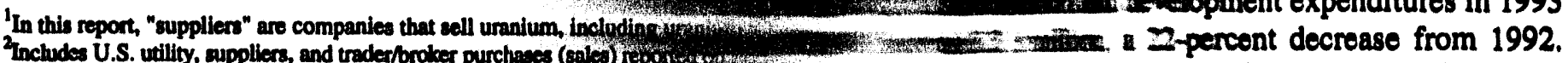
Uranium materialo reported as imports and exports under loan, exe.

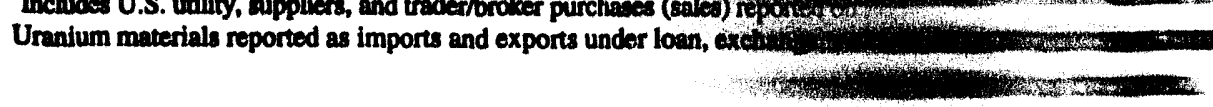


On October 30,1992, the DOC determined the first semiannual market price for uranium to be $\$ 7.95$ per pound $\mathrm{U}_{3} \mathrm{O}_{8} \mathrm{e}$ as specified under the suspension agreements. Deliveries of imported uranium from the CIS Republics were prohibited for the period October 1, 1992, through March 31, 1993. On April 1, 1993, the DOC determined a uranium market price of $\$ 11.72$ per pound $\mathrm{U}_{3} \mathrm{O}_{8}$ e. The prohibition on all imports from the six CIS Republics into the United States was continued through September 30,1993, since the DOC market price determination was below the minimum threshold price of $\$ 13.00$ per pound.

The DOC's April 1, 1993, uranium market price of $\$ 11.72$ per pound $\mathrm{U}_{3} \mathrm{O}_{8}$ was derived from an average spot price of $\$ 10.14$ per pound $\mathrm{U}_{3} \mathrm{O}_{8}$, weighted at 30.05 percent, and an average long-term price of $\$ 12.40$ per pound $\mathrm{U}_{3} \mathrm{O}_{3}$, weighted at 69.95 percent. The spot-to-long-term market volume ratio is based on a 4-year average of U.S. utility purchases during 1988 through 1991, as reported by Energy Information Administration in the Uranium Industry Annual report series.

The Ukraine on April 12, 1993, and Tajikistan on May 11,1993 , terminated their suspension agreements with the DOC. With these actions, U.S. trade law required the DOC to resume its antidumping investigation and to issue an interim determination on a dumping margin for the Ukraine and for Tajikistan. The DOC's final determination on June 29, 1993, affirmed the dumping charge for Tajikistan and the Ukraine, and the import duty for each was raised from the preliminary duty level of 115.82 percent to 129.29 percent. Based on the DOC action, the International Trade Commission (ITC) resumed its antidumping investigation. The ITC's final determination on the cases was delivered to the DOC on August 16, 1993. The findings were that no new antidumping duties would be imposed on imports of uranium from Tajikistan or HEU from the Ukraine. The ITC made an affirmative final injury determination, however, regarding imports of uranium other than HEU from the Ukraine. This final determination meant that the DOC would order the U.S. Customs Service to impose a final antidumping duty on imports of uranium other than HEU from the Ukraine.

On October 4,1993, the DOC announced that its semiannual market price determination for uranium was $\$ 11.12$ per pound. Uranium imports into the United States from the CIS Republics of Kazakhstan, Kyrgyzstan, the Russian Federation, and Uzbekistan were prohibited for the period October 1, 1993, to March 31, 1994.

On October 26, 1993, the petitioners in the uranium antidumping case, charging that the suspension agreements have been ineffective, requested that the DOC terminate the agreements with Kazakhstan, Kyrgyzstan, the Russian Federation, and Uzbekistan and resume investigations leading to a final determination. The DOC and the Russian Ministry of Atomic Energy (MINATOM) initialed an amendment to the Russian uranium-import suspension agreement in Décember 1993 in Moscow under which Russia would be allowed to sell 3,000 metric tons of natural uranium and 2 million separative work units annually, if 50 percent (minimum) of all sales are from new U.S. production. The amendment would, in effect, replace the original suspension agreement's \$13per-pound $\mathrm{U}_{3} \mathrm{O}_{8}$ threshold price, but prevent antidumping circumvention. 


\section{Uranium Raw Materials Activities}

\section{Introduction}

The development of a uranium-producing industry in the United States began in the late 1940 's, following World War II. In the years from 1947 through 1970, the domestic industry was fostered through the Govemment's uranium raw materials and procurement programs administered by the Atomic Energy Commission (AEC).

A large quantity of information about uranium as a producible commodity has been compiled by the DOE and its predecessor agencies since the AEC was established in 1946. Information from this data base has been used where appropriate in the presentation of time series data that show trends in the industry's raw materials sector. The activities that comprise the uranium raw materials sector are summarized below.

In the United States, exploration for new uranium deposits is conducted solely by the private sector. Companies decide to conduct exploration on a particular uranium property based on information from many sources, including private studies and government reports. Exploration involves the identification of prospective areas with geologically favorable characteristics; development of data on surface and subsuriace conditions using mapping, sampling, drilling, and logging; and thorough analysis and reporting of all data developed. If results are favorable, followup drilling is conducted. The aim of these efforts is to develop uranium reserves.

All information developed in a detailed exploration yrogram contributes to determining the feasibility of mining a discovered uranium deposit. The important perameters include accurate data about the deposit's depth and configuration, the distribution of uranium mineralization in the deposit, costs and the determination of cutoff grades, and the metallurgical characteristics of the deposit. If the ore is sufficiently rich in uranium to be recovered profitably, a mining operation might be established at the deposit site.
Conventional mining includes openpit and underground methods. Openpit methods can be used to produce ore from deposits located near the surface or at shallow depths. Underground mining methods are used for deposits that are deeper and that usually contain ore of a higher grade. Ore mined by conventional methods is hauled to mills for processing or to buying stations or stockpiles for future processing.

Milling of conventionally mined ore involves crushing and grinding to reduce the ore to a nearly uniform grain size, leaching with acid or alkaline reagents to extract the uranium, concentration of uranium from the leach slurry, and precipitation and drying of the uranium concentrate. In 1993, no conventional uranium mills were operated in the United States. Uranium can also be "mined" using in situ leaching methods, which involve leaching uranium from the ore "in place" without removing the ore from the ground. A leaching solution is circulated through the inplace ore, the uranium-bearing leaching solution is then pumped to the surface, and the uranium is recovered. Leaching solutions commonly employed in solution mining consist of water containing small quantities of oxygen and carbon dioxide or sodium bicarbonate. Uranium is also recovered as a byproduct from the processing of uraniferous phosphate ore. Most of the uranium concentrate produced by the U.S. industry in 1993 was from in situ leach plants and from the manufacture of wetprocess phosphoric acid.

A diagram of the major stages in the production of uranium concentrate in the domestic industry is shown in Figure 1. Delineation of exploration targets, exploration and development drilling, evaluation of discovered mineral deposits to determine reserves quantities, and mine and mill development are the major early stages. Mining and milling of uranium ore or processing of uraniferous solutions (including in situ leaching) to recover uranium concentrate complete the uranium concentrate production process. 


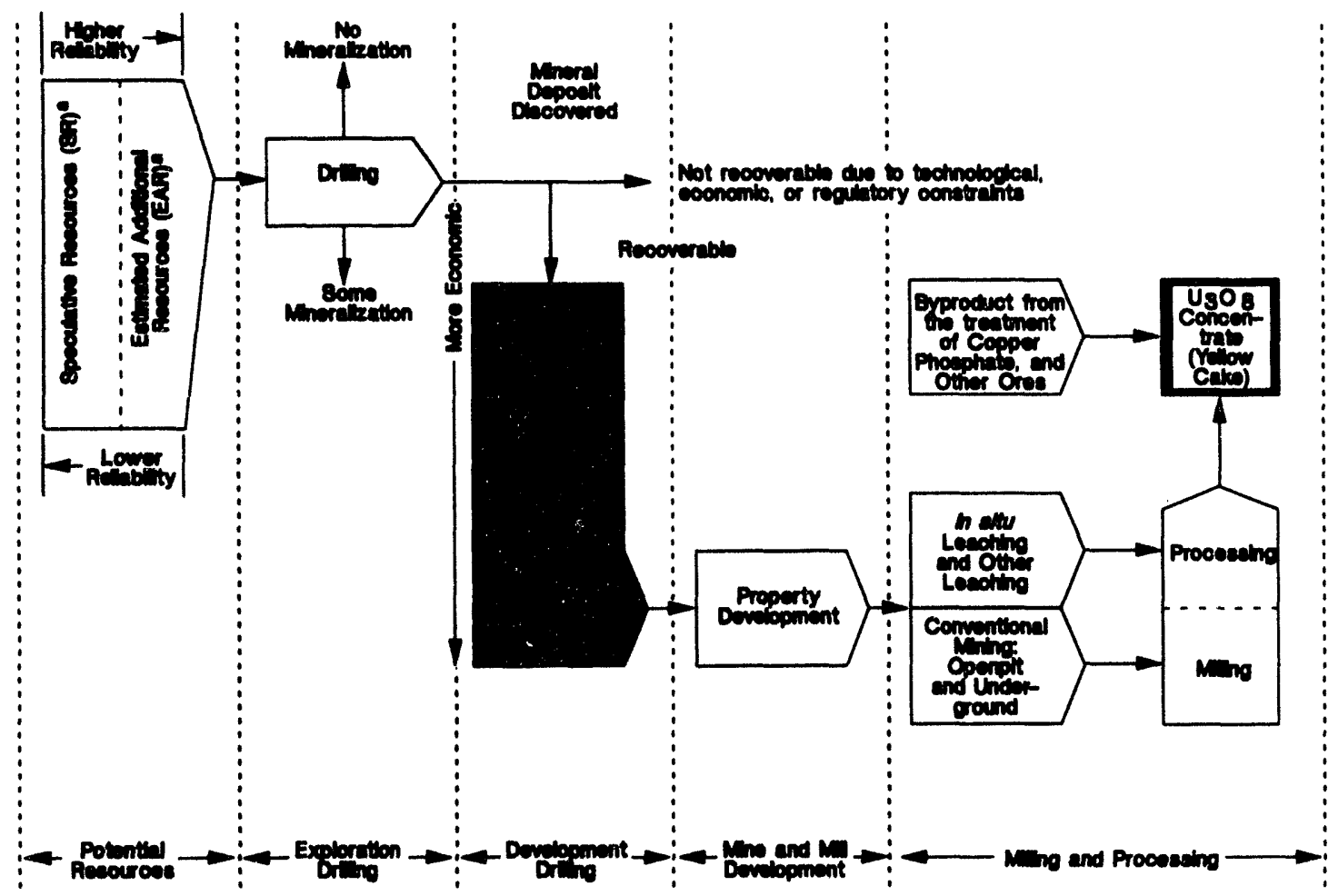

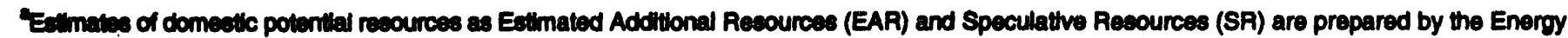

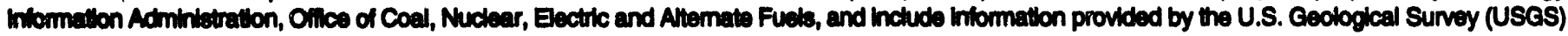
of the U.S. Department of the Intertor under a memorandum of underetanding between the USCS and the Energy Information Administration. betimates of domestic reserves are made the Energy Information Adininistration, Ofilice of Coal, Nuclear, Electric and Altemate Fuels. Source: Energy information Administration, Ofice of Coal, Nuclear, Electric and Altemate Fuels.

Estimates of minable U.S. uranium reserves at specific forwand costs are made by the Analysis and Systems Division, Energy Information Administration (EIA), through annual analysis of current and historical information on known uranium deposits. This information includes gamma ray drill hole logs, mining and geologic factors, mine production, and mining and processing practice and costs. Reserves reported in this publication are equivalent to the Reasonably Assured Resources category reported in international publications. Estimates of uranium in both the reserves and potential resources categories are made for selected forward-cost categories that are independent of the market price of uranium.
The Analysis and Systems Division also prepares estimates of potential (or undiscovered) uranium resources for various localities, some of which may lack production histories. The esti- mates incorporate current information provided by the U.S. Geological Survey (USGS), U.S. Department of the Interior, under a memorandum of understanding between the USGS and the EIA. These estimates of potential resources are reported in the international classifications of Estimated Additional Resources and Speculative Resources. The methodology for estimating reserves and potential resources is described in Appendix B. 


\section{Exploration Activities}

\section{Land Holdings and Acquisitions for Uranium Exploration}

At the end of 1993, about 0.5 million acres were held by 25 companies involved in domestic uranium exploration. This was 42 percent less than the 0.8 million acres held by 32 companies at the end of 1992 (Table 1). The amount of land held for exploration has declined each year since 1978, the peak year when 6.39 million acres were acquired. Total acreage held at the end of 1993 represents approximately 2 percent of the 19 million acres held for exploration at the end of 1978.

The amount of land acquired during 1993 was 0.07 million acres, compared with 0.09 million acres acquired in 1992 (Table 1). The amount of land acquired each year in the period 1982 through 1993 has ranged between 0.48 million acres and 0.03 million acres.

Types of land held and land acquired each year can include fee land, mineral fee, leases, patented and unpatented claims, and options to purchase mineral fee land.

Table 1. U.S. Land Held and Acquired for Uranlum Exploration, 1966-1993

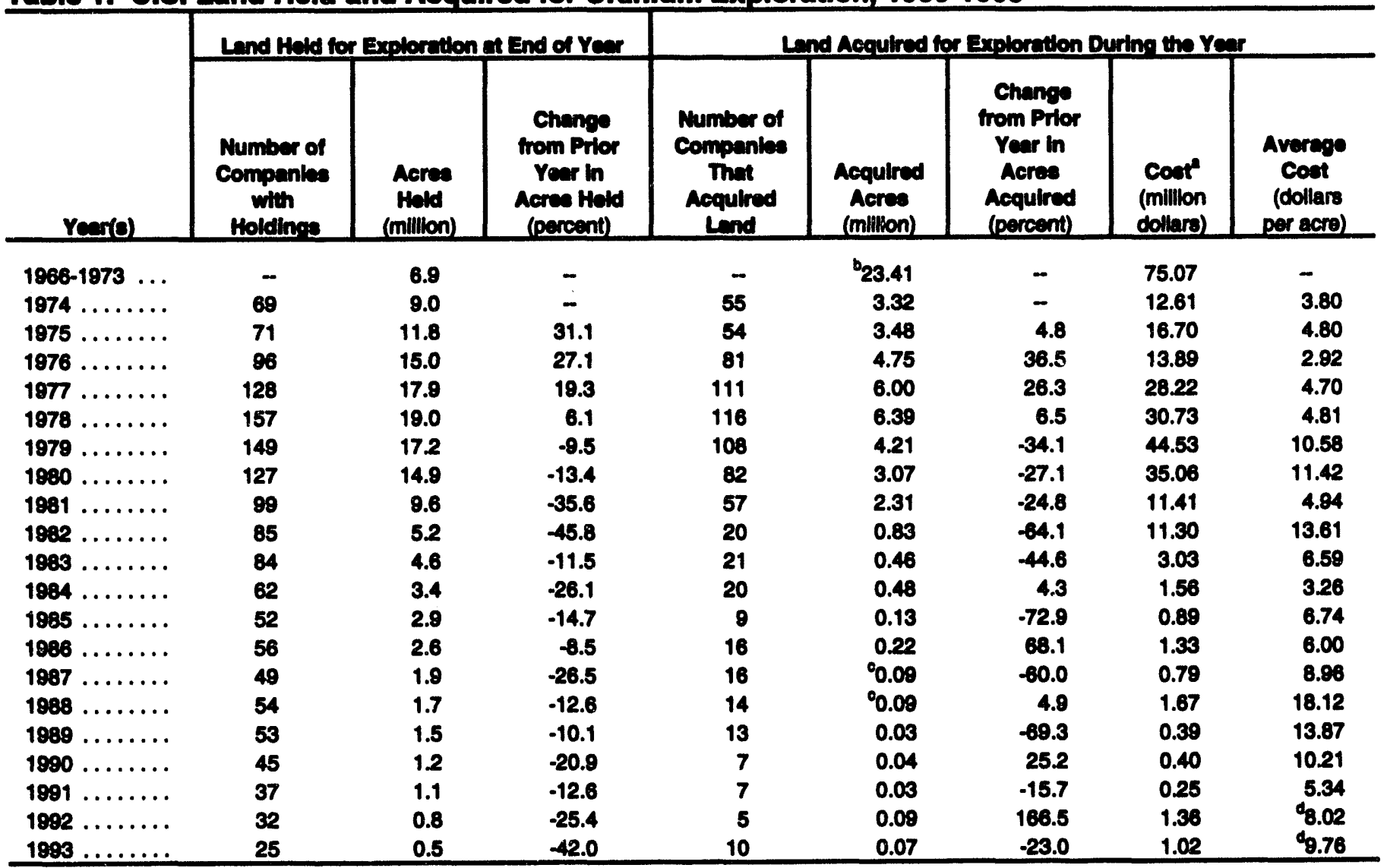

Inctudes coets for land ecquisitions and rentals in nominal dollare.

Does not inctude approximately 0.61 million ecres ecquired in the pertod $1898-1973$ for which no coet data wore reported.

Gand ecquired in 1887 was 0.088 million scres and in 1808 was 0.002 million ecres.

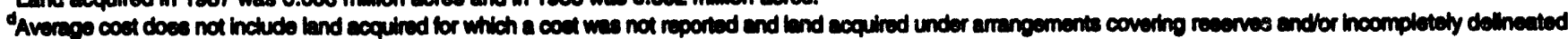
urantum depoests.

$-=$ Not applicablo.

Note: Average coet per acre shown here may not equal quotionts obtained with independently rounded numerator and denominator.

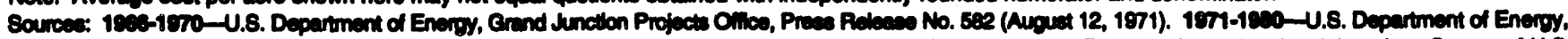

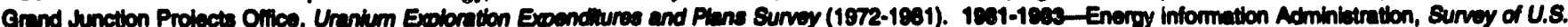

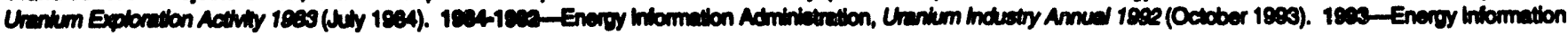
Adminiatration, Form ELA-658 Uranium Induatry Annual Surver (1809). 


\section{Land Acquisition Costs}

The total cost of land acquired during 1993 was $\$ 1.02$ million, 25 percent less than the reported total cost in 1992 (Table 1). Since 1982, annual expenditures for land acquisition have ranged between $\$ 0.25$ million and \$3.03 million. Annual expenditures for land acquisition peaked in 1979 when 4.2 million acres were acquired for $\$ 44.5$ million. Expenditures for land acquired for exploration in 1993 ranged from just over $\$ 1.00$ to about $\$ 50$ per acre. The average cost of $\$ 9.76$ per acre in 1993 was 22 percent higher than in 1992. Note that this average cost does not include the costs for land acquired under arrangements covering purchases of properties with reserves and/or partially delineated uranium deposits. From 1976 through 1993, the annual average cost (in nominal dollars) per acre of acquired land ranged from $\$ 2.92$ to $\$ 18.12$. Ten companies acquired land in 1993, compared with five in 1992.

\section{Surface Drilling}

Total surface drilling in the United States in 1993 including exploration and development drilling was 1.11 million feet in 2,020 holes (Table 2). This total footage was 4 percent greater than the 1.06 million feet reported by the industry for 1992. During 1993, eight companies conducted uranium surface drilling programs, 50 percent fewer than in 1992. The peak year for U.S. surface drilling was 1978 when total surface drilling was 48.1 million feet (Table 2). The total annual surface drilling since 1976 and drilling planned for 1994 are shown in Figure 2.

Costs incurred for surface drilling activities include those for ground surveys, road construction and site preparation, drilling, downhole geophysical surveys, sample collection, and geological and other technical support. In 1993,

Table 2. U.S. Uranium Surface Drilling Activities, 1966-1993

\begin{tabular}{|c|c|c|c|c|c|c|c|c|c|}
\hline Yendel & $\begin{array}{l}\text { Number of } \\
\text { Companles } \\
\text { Thet Dilled }\end{array}$ & $\begin{array}{l}\text { Number } \\
\text { of Holes } \\
\text { Dilled }\end{array}$ & $\begin{array}{l}\text { Chanes } \\
\text { from Prior } \\
\text { Yew In } \\
\text { Holes } \\
\text { (percent) }\end{array}$ & $\begin{array}{l}\text { Drlling } \\
\text { Footing } \\
\text { (miltion } \\
\text { foes) }\end{array}$ & $\begin{array}{l}\text { Change } \\
\text { from Pritor } \\
\text { Year in } \\
\text { Feet } \\
\text { (percent) }\end{array}$ & $\begin{array}{l}\text { Coot } \\
\text { (million } \\
\text { dollare) }\end{array}$ & $\begin{array}{l}\text { Chanes } \\
\text { from Prior } \\
\text { Your in } \\
\text { Coet } \\
\text { (porcent) }\end{array}$ & $\begin{array}{l}\text { Averige } \\
\text { Coet } \\
\text { (dollars } \\
\text { per foot) }\end{array}$ & $\begin{array}{l}\text { Change } \\
\text { from Prior } \\
\text { Year in } \\
\text { Averese } \\
\text { Coot } \\
\text { (pereent) }\end{array}$ \\
\hline $1898-1973 \ldots$ & - & 351,114 & - & 117.53 & - & 164.87 & - & 1.29 & - \\
\hline $1874 \ldots \ldots \ldots$ & 62 & 39,700 & - & 21.58 & - & 44.76 & - & 2.08 & - \\
\hline $1975 \ldots \ldots \ldots$ & 88 & 55,888 & 40.8 & 25.42 & 17.9 & 73.81 & 84.9 & 2.90 & 39.4 \\
\hline $1978 \ldots \ldots \ldots$ & 97 & 67,640 & 21.0 & 34.80 & 36.8 & 108.97 & 47.6 & 3.13 & 7.9 \\
\hline $1977 \ldots \ldots \ldots$ & 125 & 93,452 & 38.2 & 45.58 & 31.0 & 155.03 & 42.3 & 3.40 & 8.6 \\
\hline $1978 \ldots \ldots \ldots$ & 152 & 104,353 & 11.7 & 48.10 & $\mathbf{5 . 5}$ & 169.68 & 9.4 & 3.53 & 3.8 \\
\hline $1979 \ldots \ldots \ldots$ & 154 & 90,648 & -13.1 & 41.08 & -14.6 & 162.88 & -3.9 & 3.97 & 12.5 \\
\hline $1880 \ldots \ldots \ldots$ & 127 & 59,795 & -34.0 & 28.19 & -31.4 & 125.70 & -22.9 & 4.48 & 12.3 \\
\hline $1881 \ldots \ldots \ldots$ & 88 & 28,424 & -55.8 & 14.22 & 49.8 & 67.80 & -48.0 & 4.77 & 7.0 \\
\hline $1892 \ldots \ldots \ldots$ & 69 & 9,967 & -82.3 & 5.86 & -62.4 & 27.85 & -59.0 & 5.20 & 9.0 \\
\hline $1883 \ldots \ldots \ldots$ & 80 & 7,298 & -28.8 & 3.17 & -40.8 & 14.42 & -48.2 & 4.55 & -12.5 \\
\hline $1984 \ldots \ldots \ldots$ & 43 & 5,521 & -24.3 & 2.55 & -19.6 & 11.85 & -17.8 & 4.65 & 2.3 \\
\hline $18 a 5 \ldots \ldots \ldots$ & 30 & 3,649 & -33.9 & 1.76 & -80.9 & 5.58 & -53.3 & 3.14 & -32.4 \\
\hline $1888 \ldots \ldots \ldots$ & 35 & 3,831 & 5.0 & 2.07 & 17.6 & 7.74 & 39.9 & 3.74 & 19.0 \\
\hline $1897 \ldots \ldots \ldots$ & 29 & 3,814 & -0.4 & 1.86 & -5.2 & 6.98 & -10.1 & 3.55 & -5.1 \\
\hline $1888 \ldots \ldots \ldots$ & 32 & 5,205 & 36.5 & 3.01 & 53.5 & 9.70 & 39.3 & 3.22 & -9.3 \\
\hline $1989 \ldots \ldots \ldots$ & 27 & 3,840 & -28.2 & 2.22 & -26.2 & 8.94 & -7.8 & 4.00 & 25.0 \\
\hline $1890 \ldots \ldots \ldots$ & 28 & 3,415 & -11.1 & 1.68 & -24.5 & 9.15 & 2.3 & 5.45 & 35.4 \\
\hline $1891 \ldots \ldots \ldots$ & 24 & 3,187 & 6.4 & 1.84 & 9.7 & 10.95 & 19.6 & 5.84 & 9.0 \\
\hline $1892 \ldots \ldots \ldots$ & 18 & 1,768 & -44.7 & 1.08 & -42.2 & 2.43 & -77.8 & 2.28 & -81.6 \\
\hline 19:9 & 8 & 2.090 & 14.3 & 1.11 & 4.1 & 5.74 & 168.2 & 5.18 & 178.9 \\
\hline
\end{tabular}

Includes coests for exploration and development difiling in nominal dollars.

- = Not epplicablo.

Nolve: Percent chenge may not equal quotients obtained with independently rounded numerator and denominator. Average cost per foot shown here may not equal quotents with independently rounded numerator and donominator.

Eources: 1eca-1070 U.S. Energy Research and Dovelopment Administration, Grand Junction Projects Otice, Press Rolease No. 582 (August 12, 1971). 1971-

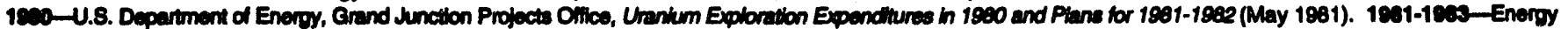

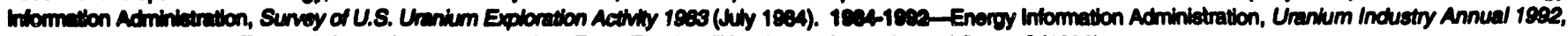
(Ocidber 1903). 19es_-Energy information Adminiatration, Form EA-6sa Unanlum industry Annual Survoy" (1993). 


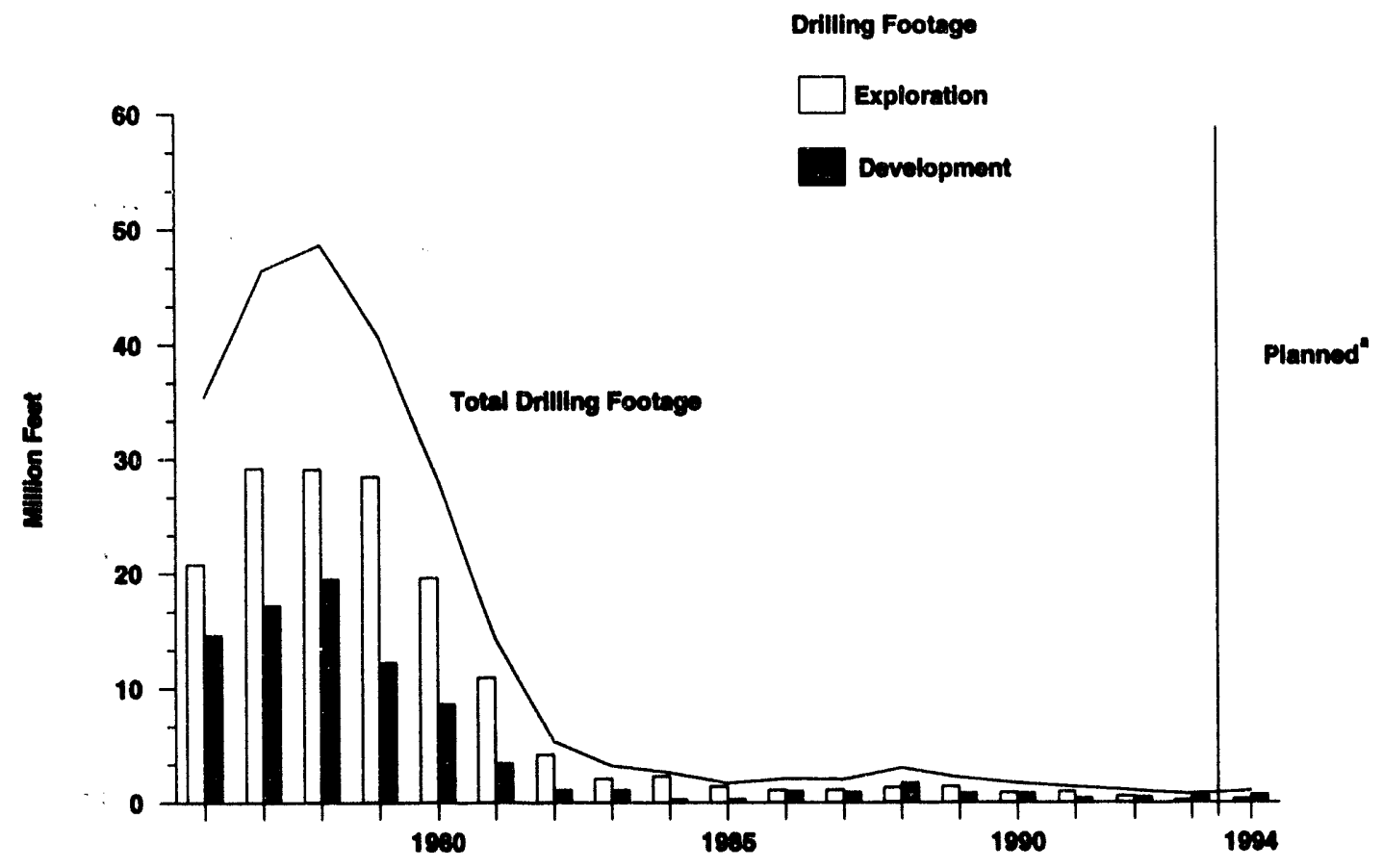

Planned as of the end of 1993.

Sourses: 1978-1980-U.S. Department of Energy, Grand Junction Projects Olice, Uranium Exploration Expenditures in 1980 and Plans for 1981-1982 (May 1981). 1981 -

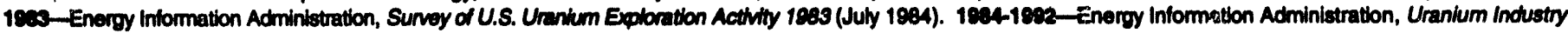
Annual 1992 (October 1993). 1993-1904-Energy Information Adminietration, Form ElA-858 "Urantum Industry Annual Surver" (1993).

the costs for surface drilling ranged from about $\$ 2.00$ to nearly $\$ 51.00$ per foot drilled. The average cost of surface drilling was $\$ 5.18$ per foot, an increase of 127 percent above the average cost per foot drilled in 1992 (Table 2).

Surface drilling for uranium consists of both exploration and development drilling (Table 3). Exploration drilling is done in search of new ore deposits or extensions of known deposits. Seven firms reported completing exploration drilling projects in 1993. The 0.22 million feet of exploration drilling during 1993 was 60 percent less than the footage reported for 1992 . A total of 355 exploration holes were drilled in 1993, a decline of 62 percent from the 935 holes completed in 1992. The average cost per foot of ex-ploration drilling in 1993 was $\$ 4.41$, nearly twice the average cost per foot of $\$ 2.25$ reported in 1992. Exploration drilling reported on Form EIA-858 includes assessment drilling completed to meet requirements for holding land under certain lease agreements. 
Table 3. U.S. Uranium Drilling by Type of Drilling, 1966-1993

\begin{tabular}{|c|c|c|c|c|c|c|c|c|}
\hline \multirow[b]{2}{*}{ Yearel } & \multicolumn{4}{|c|}{ Explortion" } & \multicolumn{4}{|c|}{ Dovelopment } \\
\hline & $\begin{array}{l}\text { Number of } \\
\text { Holes } \\
\text { Orilled }\end{array}$ & $\begin{array}{l}\text { Drilling } \\
\text { Footinge } \\
\text { (million } \\
\text { feet) }\end{array}$ & $\begin{array}{l}\text { Coetc d } \\
\text { (million } \\
\text { dollers) }\end{array}$ & $\begin{array}{l}\text { Averege } \\
\text { Cost } \\
\text { (dollars } \\
\text { per toot) }\end{array}$ & $\begin{array}{c}\text { Number of } \\
\text { Holes } \\
\text { Drillede }\end{array}$ & $\begin{array}{l}\text { Drilling } \\
\text { Footage } \\
\text { (million } \\
\text { (eet) }\end{array}$ & $\begin{array}{l}\text { Cost } \\
\text { (million } \\
\text { dollars) }\end{array}$ & $\begin{array}{l}\text { Averege } \\
\text { Cost } \\
\text { (dollars } \\
\text { per foot) }\end{array}$ \\
\hline $1966-1973 \ldots$ & 228,721 & 89.78 & 124.52 & - & 124,393 & 27.75 & 28.68 & - \\
\hline $1976 \ldots \ldots \ldots$ & 40,409 & 20.36 & 70.70 & 3.47 & 27,231 & 14.44 & 38.30 & 2.65 \\
\hline $1977 \ldots \ldots$. & 62,597 & 27.86 & 89.40 & 3.56 & 30,855 & 17.62 & 55.60 & 3.16 \\
\hline $1978 \ldots \ldots \ldots$ & 75,068 & 28.95 & 113.30 & 3.81 & 29,285 & 19.15 & 56.40 & 2.85 \\
\hline $1979 \ldots \ldots \ldots$ & 60,457 & 28.07 & 119.60 & 4.26 & 30,191 & 13.01 & 43.40 & 3.34 \\
\hline $1980 \ldots \ldots \ldots$ & 39,607 & 19.60 & 94.80 & 4.84 & 20,188 & 8.59 & 30.80 & 3.60 \\
\hline $1981 \ldots \ldots \ldots$ & 17,751 & 10.87 & 56.43 & 5.19 & 8,673 & 3.35 & 11.47 & 3.42 \\
\hline $1886 \ldots \ldots \ldots$ & 1,885 & 1.10 & 6.40 & 5.83 & 1,846 & 0.97 & 1.35 & 1.38 \\
\hline $1987 \ldots \ldots \ldots$ & 1,820 & 1.11 & 5.90 & 5.34 & 1,984 & 0.86 & 1.06 & 1.24 \\
\hline $1888 \ldots \ldots \ldots$ & 2,029 & 1.28 & 6.44 & 5.03 & 3,176 & 1.73 & 3.26 & 1.88 \\
\hline $1989 \ldots \ldots \ldots$ & 2,087 & 1.43 & 5.82 & 4.09 & 1,753 & 0.80 & 3.12 & 3.82 \\
\hline $1890 \ldots \ldots$ & 1,507 & 0.87 & 3.21 & 3.68 & 1,808 & 0.81 & 5.95 & 7.37 \\
\hline $1891 \ldots \ldots \ldots$ & 1,624 & 0.97 & 2.83 & 2.91 & 1,573 & 0.87 & 8.11 & 9.33 \\
\hline $1892 \ldots \ldots \ldots$ & 935 & 0.56 & 1.27 & 2.25 & 833 & 0.50 & 1.16 & 2.31 \\
\hline عسشس_ 1993 & 355 & 0.02 & 0.98 & 4.41 & 1.665 & 0.88 & 4.75 & 5,37 \\
\hline
\end{tabular}

Tnctudes aceseament drilling and drilling in search of new ore depoelts or extensions of known depoelts and dilling at the location of a decovery up to the time the company decides sulficient ore reserves are present to fuettly commercial explottation.

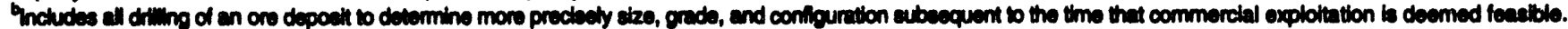

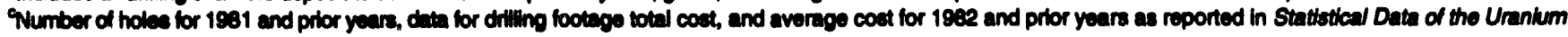
Industry, GNO-100/(83) (January 1, 1983). Coets shown are in nominal dollars.

boes not include the costs for 2.074 million foet of exploration dilling and 0.53 million feet of dovelopment drilling for 1986-1971 for which drilling coets were reported

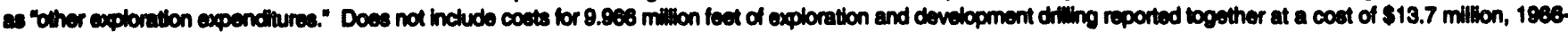
1972.

"This high value is attributuble primarly to the large percentage of the total expenditures for development dilling in 1892 contributed by one company.

$-=$ Not applicable

Note: Average coet per foot shown here may not equal quotients obtained with independently rounded numerator and denominator.

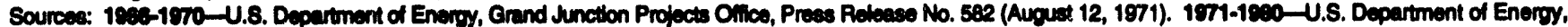

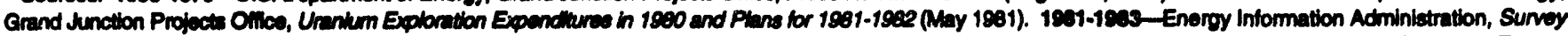

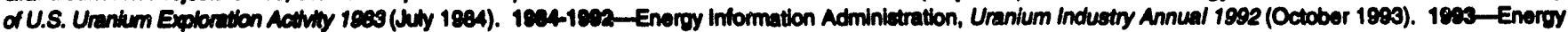
Information Adminiatration, Form ElA-6s8 Uranlum Induetry Annual Burvey" (1993).

Development drilling is done to define the size, shape, and grade of known deposits and to provide data needed for mine planning. In 1993, 0.88 million feet of development drilling was completed in 1,665 holes (Table 3 ). Development drilling was reported by six companies for 1993, compared with nine in 1992. During the period 1989 through 1993, annual development drilling has been less than 1 million feet each year. The average cost per foot of development drilling in 1993 was \$5.37, more than 130 percent higher than in 1992.

For most individual drilling programs in 1993, the reported average cost-per-foot drilled ranged between $\$ 1.00$ to near $\$ 9.00$ for exploration drilling and between
$\$ 1.00$ to near $\$ 8.00$ for development drilling. Of the seven exploration drilling programs reported for 1993, a majority drilled between 10,000 and 100,000 feet. Of the six development drilling programs reported for 1993, a majority drilled less than 100,000 feet.

\section{Uranium Surface Drilling Footage by State}

Surface drilling in 1993 was conducted in Arizona, Colorado, Nebraska, Texas, and Wyoming. Compared with 1992, total surface drilling footage in 1993 increased 
in Texas and Wyoming and decreased in Arizona, Colorado, and Nebraska. Wyoming accounted for about 71 percent of the total surface drilling footage reported in 1993 (Table 4). Surface drilling was reported for New Mexico and Utah in 1992, but none was reported for 1993. Exploration drilling footages increased in Arizona but decreased in Colorado, Nebraska, Texas, and Wyoming. Development drilling in 1993 decreased in Arizona but increased in Colorado, Nebraska, Texas, and Wyoming. Drilling data for Arizona, Colorado, Nebraska, and Texas are combined in Table 4 and Figure 3 into the "Other" category to avoid disclosure of company-specific data.

Table 4. Uranlum Surface Drilling by State and Type of Drilling, 1993

\begin{tabular}{|c|c|c|c|c|c|c|c|c|}
\hline \multirow[b]{2}{*}{ 8tate } & \multicolumn{2}{|c|}{ Exploration } & \multicolumn{2}{|c|}{ Dovelosment } & \multicolumn{2}{|c|}{ Total } & \multicolumn{2}{|c|}{$\begin{array}{c}\text { Total as a } \\
\text { Percent of U.8. Total } \\
\end{array}$} \\
\hline & $\begin{array}{c}\text { Number of } \\
\text { Holes }\end{array}$ & $\begin{array}{c}\text { Thousand } \\
\text { Feet }\end{array}$ & $\begin{array}{c}\text { Number of } \\
\text { Holes }\end{array}$ & $\begin{array}{c}\text { Thousand } \\
\text { Feet }\end{array}$ & $\begin{array}{c}\text { Number of } \\
\text { Holes }\end{array}$ & $\begin{array}{c}\text { Thousand } \\
\text { Foot }\end{array}$ & $\begin{array}{c}\text { Number of } \\
\text { Holes }\end{array}$ & $\begin{array}{l}\text { Drilling } \\
\text { Footage }\end{array}$ \\
\hline Wyoming .... & 215 & 135 & 1,288 & 656 & 1,503 & 791 & 74.4 & 71.4 \\
\hline Other ....... & 140 & 88 & 377 & 229 & 517 & 317 & 25.6 & 28.6 \\
\hline$T+1$ & 355 & $29 x$ & $18 \times 5$ & 89.5 & 2.090 & 1.102 & $10,0.0$ & 10.0 .0 \\
\hline
\end{tabular}

includes Aizona, Colorado, Nebraska, and Texas.

Notes: Totals may not equal sum of components because of independent rounding. Percentages were calculated using unrounded data.

Sourca: Enorgy Information Administration, Form EIA-858, Uranium Induatry Annual Survey" (1898).

\section{Figure 3. Total Surface Drilling Footage by State, 1991-1993}

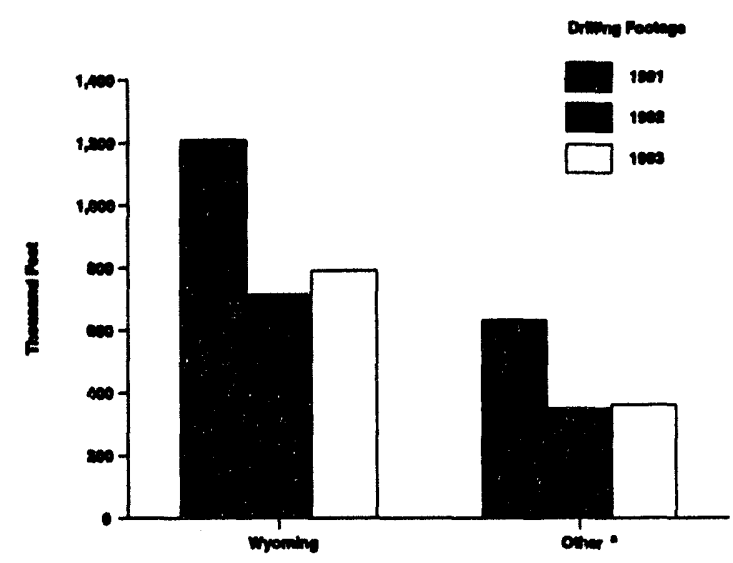

Other: 1901-1ern_Artzina, Colorado, Nebraska, New Moxico, Toxas, and Utah. 1eas-Arizona, Colorado, Nebracka, and Texas.

Sources: 1822: Eneroy Information Adminiatration, Uranium Industry Annual 1992 (October 1993). 19:3: Energy Information Administration, Form ElA-858 "Uranium incustry Annual Survor" (1893)

\section{Total Domestic Uranium Exploration Expenditures}

The total expenditures for uranium exploration shown in Table 5 include all expenditures for land acquired and held, surface exploration and development drilling costs, and other exploration expenditures. Total exploration expenditures in 1993 were $\$ 11.27$ million, approximately 22 percent less than the total expenditures in 1992. The 1993 total consisted of $\$ 1.02$ million for land acquisition, $\$ 5.74$ million for surface drilling, and \$4.51 million for other exploration activities. $^{1}$

For 1993, 15 companies incurred costs for exploration activities in the other exploration expenditures category. This expenditures category decreased by 22 percent compared with the 1992 level. Costs for land acquisition, drilling, or work in foreign countries are not included in other exploration expenditures. Expenditures by U.S. companies for exploration in foreign countries were reported as zero during 1993, and like expenditures planned for 1994 were also reported as zero on the 1993 survey.

\footnotetext{
'The category "other exploration expenditures" includes costs for geologic and geophysical investigations and research costs incurred by field personnel during exploration, assessment work other than drilling, and overhead and administrative charges specifically associated with supervising and supporting exploration activities.
} 
Table 5. U.S. Uranium Exploration and Development Expenditures, 1966-1993

\begin{tabular}{|c|c|c|c|c|c|c|c|c|c|}
\hline \multirow[b]{2}{*}{ Yearol } & \multicolumn{2}{|c|}{ suriese Dillin. } & \multicolumn{2}{|c|}{ Lend Acouldition } & \multicolumn{2}{|c|}{$\begin{array}{c}\text { Other Explorition } \\
\text { Expencthume }\end{array}$} & \multicolumn{3}{|c|}{ Total Expendituree } \\
\hline & $\begin{array}{l}\text { Number of } \\
\text { Compenias" }\end{array}$ & $\begin{array}{c}\text { Coot } \\
\text { (million } \\
\text { dollars) }\end{array}$ & $\begin{array}{l}\text { Number of } \\
\text { Companise }\end{array}$ & $\begin{array}{l}\text { Coot } \\
\text { (million } \\
\text { dollans) }\end{array}$ & $\begin{array}{l}\text { Number of } \\
\text { Compenlese }\end{array}$ & $\begin{array}{l}\text { Cost } \\
\text { (million } \\
\text { dollars)' }\end{array}$ & $\begin{array}{l}\text { Number of } \\
\text { Companies }\end{array}$ & $\begin{array}{c}\text { Coot } \\
\text { (million } \\
\text { dollars) }\end{array}$ & $\begin{array}{l}\text { Percent } \\
\text { Change } \\
\text { from Prlor } \\
\text { Year }\end{array}$ \\
\hline $1989-1973 \ldots$ & - & 164.87 & - & 75.07 & - & 94.43 & - & 334.37 & - \\
\hline $1974 \ldots \ldots \ldots$ & 62 & 44.76 & 55 & 12.61 & NA & 21.71 & 83 & 79.08 & - \\
\hline $1975 \ldots \ldots \ldots$ & 66 & 73.81 & 54 & 18.70 & NA & 31.62 & 86 & 122.03 & 54.3 \\
\hline $1978 \ldots \ldots \ldots$ & 97 & 108.97 & 81 & 13.89 & NA & 47.79 & 108 & 170.65 & 39.8 \\
\hline $1977 \ldots \ldots \ldots$ & 125 & 155.03 & 111 & 28.22 & NA & 74.83 & 146 & 258.08 & 51.2 \\
\hline $1978 \ldots \ldots \ldots$ & 152 & 169.68 & 116 & 30.73 & NA & 113.86 & 174 & 314.26 & 21.8 \\
\hline $1979 \ldots \ldots \ldots$ & 154 & 182.88 & 108 & 44.53 & NA & 108.40 & 164 & 315.91 & 0.5 \\
\hline $1980 \ldots \ldots \ldots$ & 127 & 125.70 & 82 & 35.08 & NA & 108.20 & 147 & 268.96 & -15.5 \\
\hline $1981 \ldots \ldots \ldots$ & 96 & 67.90 & 57 & 11.41 & NA & 65.45 & 107 & 144.76 & -45.8 \\
\hline $1982 \ldots \ldots \ldots$ & 69 & 27.85 & 20 & 11.30 & 64 & 34.47 & 85 & 73.61 & -49.2 \\
\hline $1983 \ldots \ldots \ldots$ & 60 & 14.42 & 21 & 3.03 & 68 & 19.41 & $\pi$ & 36.86 & -49.9 \\
\hline $1984 \ldots \ldots \ldots$ & 42 & 11.85 & 20 & 1.58 & 32 & 13.07 & 53 & 26.48 & -28.2 \\
\hline $1885 \ldots \ldots \ldots$ & 30 & 6.53 & 9 & 0.89 & 34 & 13.67 & 40 & 20.10 & -24.1 \\
\hline $1888 \ldots \ldots \ldots$ & 35 & 7.74 & 16 & 1.33 & 34 & 12.99 & 60 & 22.06 & 9.8 \\
\hline $1887 \ldots \ldots \ldots$ & 29 & 6.88 & 16 & 0.79 & 34 & 11.92 & 42 & 19.67 & -10.8 \\
\hline $1888 \ldots \ldots \ldots$ & 32 & 9.70 & 14 & 1.67 & 31 & 8.73 & 44 & 20.10 & 2.2 \\
\hline $1989 \ldots \ldots \ldots$ & 27 & 8.84 & 13 & 0.39 & 24 & 5.49 & 39 & 14.77 & -28.5 \\
\hline $1890 \ldots \ldots \ldots$ & 26 & 9.15 & 7 & 0.40 & 31 & 7.58 & 40 & 17.12 & 15.9 \\
\hline $1891 \ldots \ldots \ldots$ & 24 & 10.95 & 7 & 0.25 & 19 & 6.65 & 30 & 17.84 & 4.2 \\
\hline $1892 \ldots \ldots \ldots$ & 16 & 2.43 & 5 & 1.38 & 21 & 10.72 & 28 & 14.51 & -18.7 \\
\hline 1989 & 8 & 5.74 & 7 & $10 \%$ & 15 & 4.61 & 18 & 11.27 & $-22,3$ \\
\hline
\end{tabular}

Companies reporting surface drlling, which includes exploration and development drliting.

includes costs for exploration and development in nominal dollars.

companies reporting land acquistions and rentals.

Inctudes costs for tand acquisitions and rentals in nominal dollars.

'Companies reporting other exploration expenditures.

includes costs, in nominal dollars, for geologic and geophysical inveatigations and rescarch coats incurred by field personnel during exploration, and overhead and adminietrattve charges specifically aseociated with supervising and supporting exploration activities.

- = Not applicable.

NA = Not avallable.

Note: Totals may not equal sum of components because of independent rounding.

Sources: 1ce3-1974-U.S. Energy Research and Development Admintetration, Grand Junction Projects Otilce, Uranlum Exploration Exponditures in 1974 and Plans for 1975-1978 (Aprit 1975). 1978-19e3-Energy Information Adminiatration, Survoy of U.S. Urantum Exploration Activity 1983 (July 1894). 1984-1992-Energy Iniomation Adrinistration, Uranium Industry Anmual 1992 (October 1993). 1998-Eneroy Information Adminietration, Form EIA-858, "Uranium Industry Annual Survoy" (1898).

\section{Foreign Participation in Domestic Uranium Exploration}

Expenditures from foreign sources in U.S. exploration activities during 1993 were $\$ 8.5$ million, a 6-percent increase above the total of $\$ 8$ million from foreign sources in 1992 (Table 6). "Foreign" means majorityowned by non-U.S. entities. Foreign participation in 1993 accounted for about 76 percent, a record level, of the total domestic industry exploration expenditures, up from 55 percent in 1992. In terms of total dollars spent, foreign participation in 1993 at $\$ 8.5$ million was at the.highest level since 1988 when $\$ 8.9$ million were expended by foreign companies in exploration in the U.S. industry. Seven companies reported participation in 1993 from foreign sources, one more than in
1992. The dollar amounts contributed from foreign sources are included in all exploration expenditures totals shown in this report.

\section{Planned and Actual U.S. Uranium Exploration and Development Activities, 1980 Through 1992}

A total of eight companies reported actual exploration and development drilling activities for 1993. In comparison, 10 companies reported on the 1992 survey that they had planned exploration and development drilling programs for 1993 . The actual total surface drilling reported for 1993 was 1.1 million feet, 45 percent more that the projected (planned for 1993) amount reported on the 1992 survey. Statistics for act- 
Table 6. Forelgn Participation In U.S. Uranlum Exploration, 1976-1993

\begin{tabular}{|c|c|c|c|}
\hline \multirow[b]{2}{*}{ Year } & \multirow[b]{2}{*}{$\begin{array}{c}\text { Number of Companies } \\
\text { Reporting }\end{array}$} & \multicolumn{2}{|c|}{ Expendituree } \\
\hline & & Million Dollars & $\begin{array}{c}\text { Percent of } \\
\text { Total U.S. Expenditures } \\
\end{array}$ \\
\hline $1976 \ldots \ldots \ldots \ldots \ldots \ldots \ldots$ & 15 & 13.2 & 8 \\
\hline $1977 \ldots \ldots \ldots \ldots \ldots \ldots \ldots \ldots$ & 17 & 21.7 & 8 \\
\hline $1978 \ldots \ldots \ldots \ldots \ldots \ldots \ldots \ldots$ & 31 & 39.3 & 13 \\
\hline $1979 \ldots \ldots \ldots \ldots \ldots \ldots \ldots \ldots$ & 28 & 34.1 & 11 \\
\hline $1980 \ldots \ldots \ldots \ldots \ldots \ldots \ldots$ & 28 & 37.6 & 14 \\
\hline $1981 \ldots \ldots \ldots \ldots \ldots \ldots \ldots$ & 25 & 24.6 & 17 \\
\hline $1982 \ldots \ldots \ldots \ldots \ldots \ldots \ldots \ldots$ & 14 & 14.6 & 20 \\
\hline $1983 \ldots \ldots \ldots \ldots \ldots \ldots \ldots$ & 9 & 4.8 & 13 \\
\hline $1984 \ldots \ldots \ldots \ldots \ldots \ldots \ldots$ & 9 & 6.6 & 25 \\
\hline $1985 \ldots \ldots \ldots \ldots \ldots \ldots \ldots$ & 6 & 5.6 & 28 \\
\hline $1986 \ldots \ldots \ldots \ldots \ldots \ldots \ldots$ & 8 & 12.0 & 55 \\
\hline $1987 \ldots \ldots \ldots \ldots \ldots \ldots \ldots$ & 11 & 11.9 & 60 \\
\hline $1988 \ldots \ldots \ldots \ldots \ldots \ldots \ldots$ & 11 & 8.9 & 44 \\
\hline $1989 \ldots \ldots \ldots \ldots \ldots \ldots \ldots \ldots$ & 7 & 6.1 & 42 \\
\hline $1990 \ldots \ldots \ldots \ldots \ldots \ldots \ldots$ & 9 & 2.5 & 15 \\
\hline $1991 \ldots \ldots \ldots \ldots \ldots \ldots \ldots \ldots$ & 6 & 3.5 & 19 \\
\hline $1992 \ldots \ldots \ldots \ldots \ldots \ldots \ldots \ldots$ & 6 & 8.0 & 55 \\
\hline $1993 \ldots \ldots \ldots$ & 7 & 8.5 & 76 \\
\hline
\end{tabular}

Note: Expenctures are in nominal dollars and inctude expencitures for land scquired and held, surtace dritling, and "other exploration expenditures," which inctudes geologic and geophyeical investigations and research coets hourred by field personnel during exploration, and overhead and administrative charges spectically aseociated with supervieing and supporting exploration activities.

Sources: 1976-19e0-U.S. Department of Energy, Grand Junction Projects Olice, Uranium Exploration Expenditures and Plans Survey (1976-1980). 160119es-Energy Information Administration, Survoy of U.S. Urantum Exploration Activly 1833 (July 1984). 1994-1892-Energy Information Adminlatration, Uranium Inctustry Anmual 1992 (October 1993). 1903-Energy Information Adminiatration, Form ElA-658 Uranium Industry Annual Survor" (1993).

ual and planned exploration activities for 1980 through 1993 and planned activities for 1994 are shown in Table 7. Total surface drilling footage planned for 1994 is projected to be 8 percent less than the actual amount of drilling reported for 1993 . The total planned drilling expenditures for 1994 are 24 percent greater than like expenditures reported as planned for 1993.

\section{U.S. Uranium Resources and Reserves}

\section{Potential Uranium Resources}

Estimates of potential (undiscovered) uranium resources for the classes of Estimated Additional Resources (EAR) and Speculative Resources (SR) at forward-cost categories of $\$ 30$-, $\$ 50$-, and $\$ 100$-perpound $\mathrm{U}_{3} \mathrm{O}_{8}$ are made annually by the EIA. Within each forward-cost category, the estimates of resources at each cost level are cumulative and include all lower cost resources within that category. Because of limited direct-sample data, the estimation of potential uranium resources is not precise, and the reliability of the estimates is subject to some uncertainty.

Assistance provided by the U.S. Geological Survey (USGS) to the EIA in support of the estimation of potential resources and the methodology used are described in Appendix B along with an explanation of the potential uranium resources estimates for 1993 and historical estimates.

For 1993, the mean values of EAR and SR for the $\$ 30-, \$ 50-$, and $\$ 100$-per-pound $\mathrm{U}_{3} \mathrm{O}_{8}$ forward-cost categories declined slightly when compared with the 1992 values (Table 8). 
Table 7. Planned and .1otual U.8. Surtece Drilling by Drllling Type and Expendituree, 1981-1904

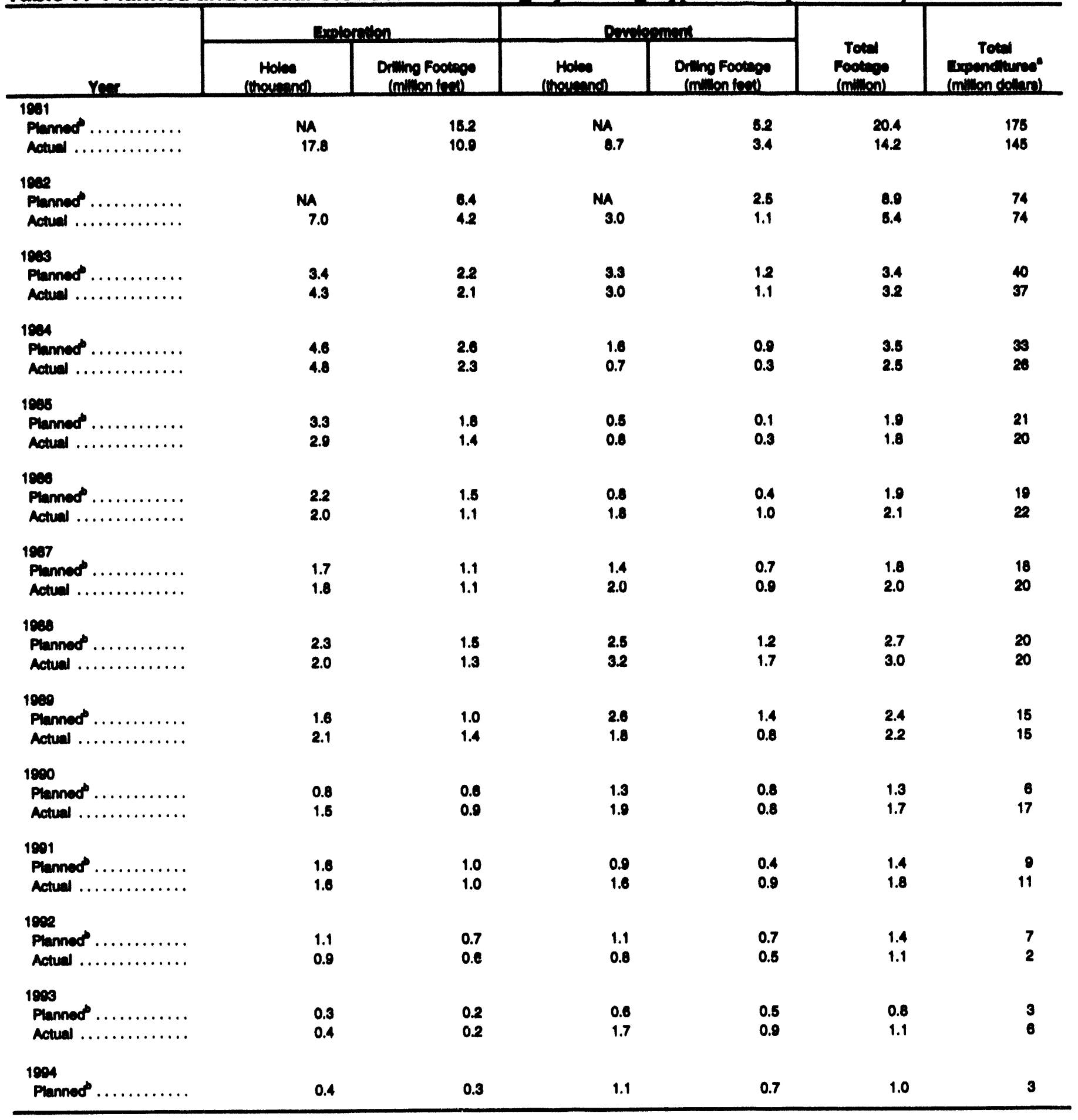

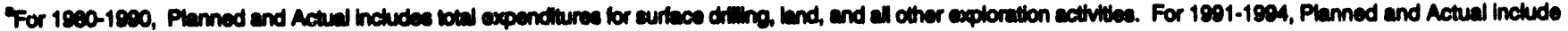
tofed expenditures for eurtace drilling only. Expenditures thown are in nominal dollare.

Battivy for the year indicated, planned at the end of the provious year.

NA = Not avaliablo.

Note: Totals may not equal sum of components because of independent rounding.

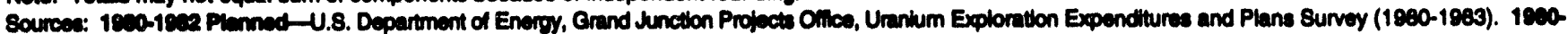

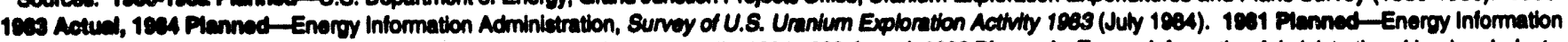

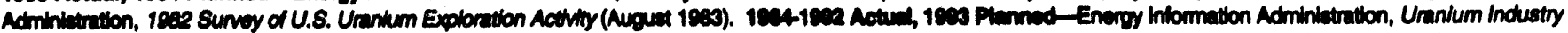

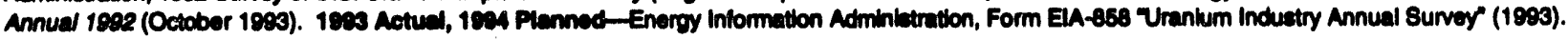


Tablo 8. U.8. Potentlal Uranlum Resources by Forward-Cost Catogory, 1992, 1993 (Million Pounds $\left.U_{3}, 0_{1}\right)$

\begin{tabular}{|c|c|c|c|c|c|c|}
\hline \multirow[b]{3}{*}{ Year } & \multicolumn{6}{|c|}{ Fonwend-Cont Coterony } \\
\hline & \multicolumn{2}{|c|}{ seper pound } & \multicolumn{2}{|c|}{ seo perpound } & \multicolumn{2}{|c|}{1100 pex pound } \\
\hline & EAR* & $8 R^{0}$ & EAR' & $98^{b}$ & EAR" & $S A^{b}$ \\
\hline $1892 \ldots \ldots \ldots$ & 2,200 & 1,300 & 3,400 & 2,300 & 4,800 & 3,500 \\
\hline $1003 \ldots \ldots \ldots$ & 2,200 & 1,336 & 3,340 & 2,280 & 4,880 & 3,510 \\
\hline
\end{tabular}

EAP = Eettmated Additional Recources.

BA = Epeculative Reecources.

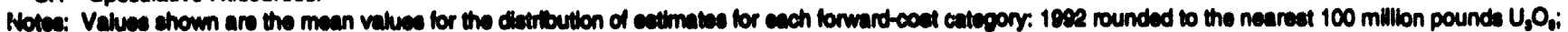

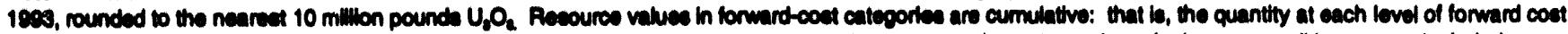

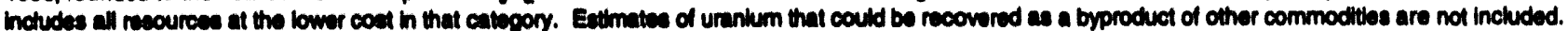

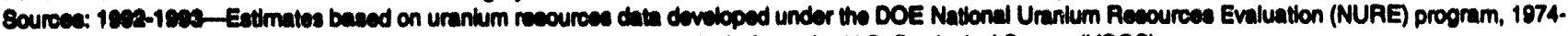

16es, and updated as new new data on unnium recources become avalleble from the U.8. Ceobogkal Eurvey (USGS).

\section{U.S. Uranium Reserves}

Uranium reserves consist of the estimated quantities of uranium (as $\mathrm{U}_{3} \mathrm{O}_{8}$ ) occurring in known deposits of such grade, quantity, configuration of mineralized rock, anddepth, that, based on mining analyses and engineering calculations, portions of the mineralized deposits can be recovered at specified costs under current regulations using state-of-the art mining and processing. The specified costs, which comprise the forward-cost categories, are not the same as market prices. The EIA category of "uranium reserves" is equivalent to the internationally reported category of Reasonably Assured Resources (RAR). Using historical data, industry information, and the reserves data and estimating parameters for individual properties reported on the 1993 Form EIA-858, the EIA prepared the national estimates of uranium reserves presented in this section. Reserves totals are presented for selected forward-cost categories that cover a broad range of costs for both short-term and long-term planning for the supply and procurement of uranium as well as for planning the development of energy programs by Government and industry. Costs used in deriving the 1993 reserves estimates include capital and operating costs associated with mining, transporting, and processing of the uranium ores. Uranium recovery factors normally encountered in actual mining and milling operations were used in the estimations.

Estimates of uranium reserves for 1992 and 1993 are shown in Table 9. As of the end of 1993, the estimate of reserves in the \$30-per-pound category located in 243 properties was 292 million pounds $\mathrm{U}_{3} \mathrm{O}_{8}, 1$ percent less than in 1992. Similarly, the estimates for 1993 of 952 million pounds $\mathrm{U}_{3} \mathrm{O}_{8}$ reserves in the $\$ 50$-per-pound cate-

Table 9. Changes in U.S. Uranium Reserves by Forward-Cost Category, 1992 to 1993 (Million Pounds $\mathrm{U}_{3} \mathrm{O}_{9}$ )

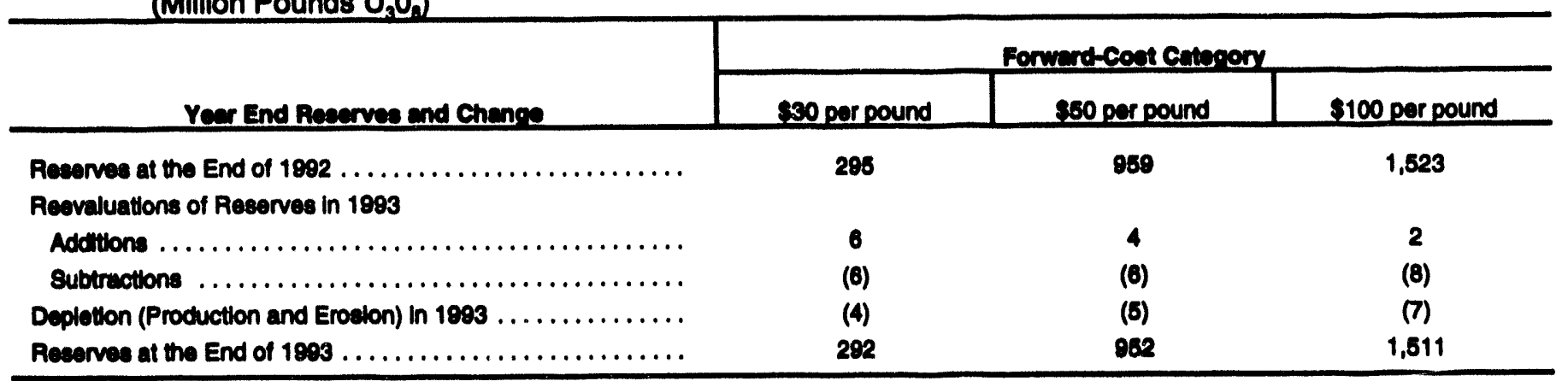

Nove: Toule may not equal sum of componente because of independent rounding. No recerves evaluations for new urantum propertiea are included in the eatimates of U.8. neerves made duing 18e3. Uranium resenves that could be recovered es a byproduct of phosphate and copper mining are not included in this table. Reserves values in formard-coet categorles are cumulative: that is, the quanthy at esch level of fonmard coet includes all reserves at the lower coste.

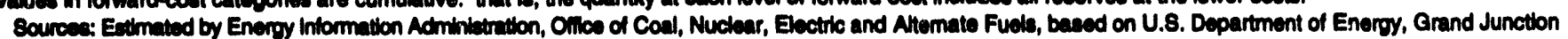
Projects Oilice data filos and Fom EIA-868, Uranlum Induetry Annual Survey" (1893). 
gory and 1,511 million pounds in the \$100-per-pound category are each 1 percent below the corresponding estimate at the end of 1992. Most of the decrease in reserves was the result of the reevaluation of selected uranium property reserves based on new data and on costs, depletion, and availability of milling facilities within reasonable haulage distance. Estimates of reserves by State are shown in Table 10 and Figure 4 . Three
States, New Mexico, Texas, and Wyoming, contain about 75 percent of $\$ 30$-per-pound $\mathrm{U}_{3} \mathrm{O}_{8}$ reserves.

Based on the reserve data reported on Form EIA-858 and on evaluation of ELA-held historical uranium-property data, an assessment was made of the distribution of reserves most likely to be extracted by underground, openpit, in situ leaching, or other methods of mining.

Table 10. Uranlum Reserves by 8tate and Forward-Cost Category, 1993

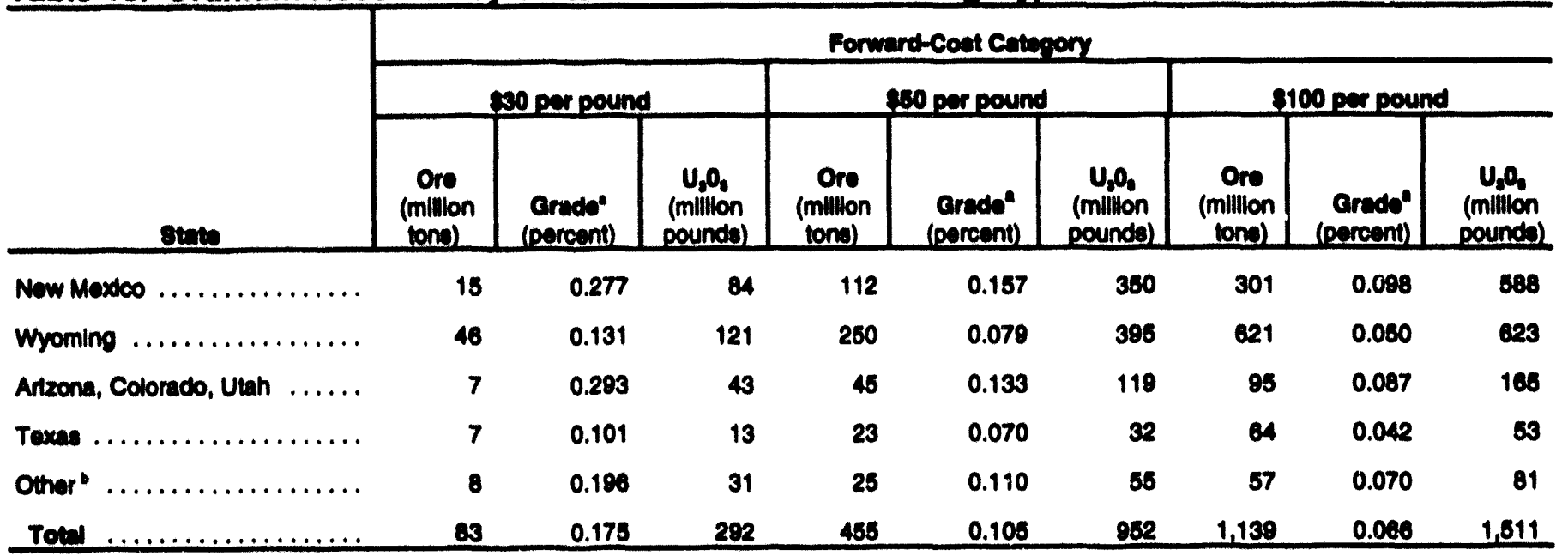

- Welinted average.

- Incudes Calliomin, Idaho, Nobreske, Novada, North Dakota, Oregon, Eouth Dakota, and Wachingion.

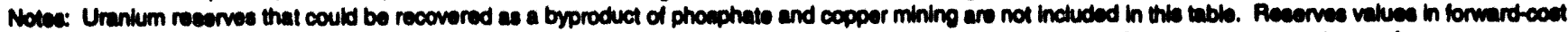
categores are cumulativ: that is, the quantity at each level of lonward-cost includes all reserves at the lower coete. Totals may not equal eum of components becuses of independent rounding.

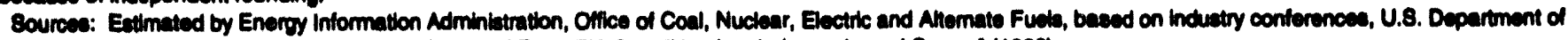
Energy, Grand Junction Projects Oillce data fies, and Form ElA-858, Uranium Induetry Annual Burver" (1893).

\section{Figure 4. Uranlum Recerves by State, 1993}

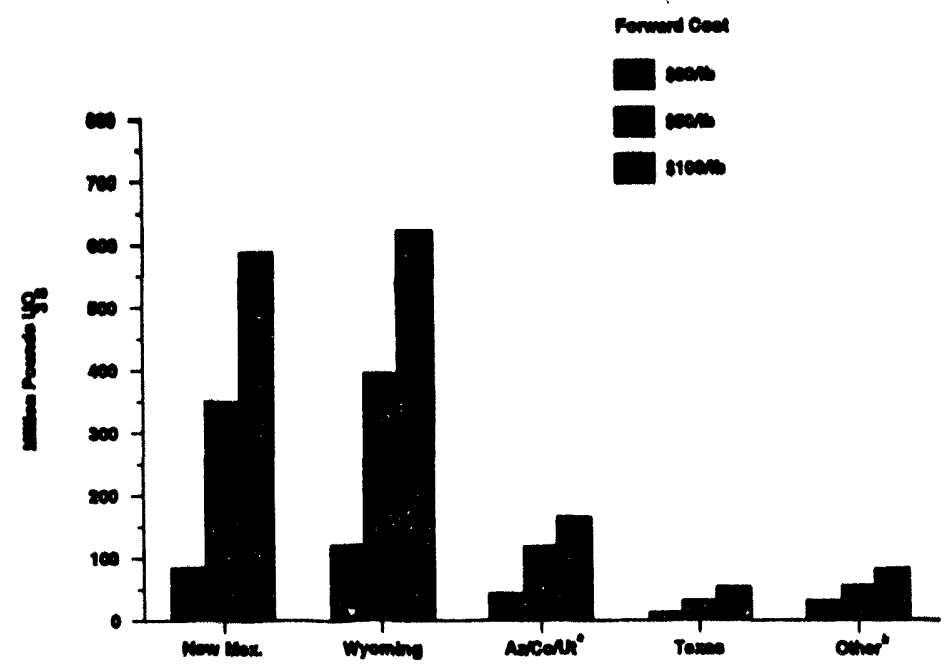

Arizon, Colorado, and Utah.

Hnciudes Callomia, Idaho, Nebraska, Nevada, North Dakota, Oregen, South Dakota, and Wachington.

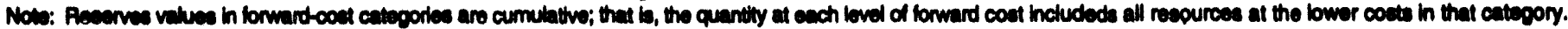

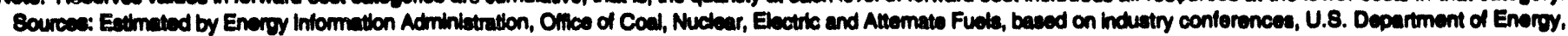
Crand Junction Projects Omices dati flies and Energy Information Adminiatration, Form ElA-6s8 "Uranlum Industry Annual 8urvor" (1098). 
This distribution of reserves by expected mining method is presented in Table 11 and Figure 5. Conventional underground mining continues to be the dominant method, accounting for about one-half of the total reserves in each cost category. In the \$30-per-pound cost category, in situ leaching is the second largest mining method, and in the $\$ 50$ and $\$ 100$-per-pound categories, openpit mining is the second largest method.

\section{U.S. Mine Production of Uranium}

Production from in situ leach mines and other sources during 1993 totaled 2.0 million pounds $\mathrm{U}_{3} \mathrm{O}_{8}$, an increase of 105 percent above the 1.0 million pounds produced during 1992 (Table 12). Commercial-scale in situ leach mining operations located in Nebraska (one), Texas (one), and Wyoming (three) accounted for about 98 percent of total U.S. mine production in 1993 (Table 13). Other sources, such as recovery of uranium from mine water and restoration of mined-out in situ leach well fields accounted for about 3 percent. Figure 6 shows historical mine production of uranium for the years 1968 through 1993. The number of sources for mine production of uranium that were operating each year from 1982 through 1993 are shown on Table 14.

\section{Table 11. U.8. Uranium Recervee by Mining Mothod and Forward-Coot Caterory, 1998}

\begin{tabular}{|c|c|c|c|c|c|c|c|c|c|}
\hline \multirow[b]{3}{*}{ 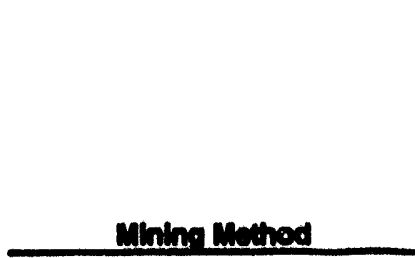 } & \multicolumn{9}{|c|}{ Fonward-Coot } \\
\hline & \multicolumn{3}{|c|}{ sop per pound } & \multicolumn{3}{|c|}{200 pes pound } & \multicolumn{3}{|c|}{100 ber peund } \\
\hline & $\begin{array}{c}\text { Onfo } \\
\text { (mintion } \\
\text { (tom })\end{array}$ & (Precent) & 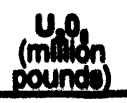 & $\underset{\text { (mition }}{\text { onition }}$ & (Precenent) & $\operatorname{liming}_{\text {pounding }}$ & $\underset{\text { (milition }}{\text { ond }}$ & (precoent) & 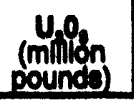 \\
\hline Underground ....... & 28 & 0.274 & 140 & 143 & 0.168 & 400 & 300 & 0.000 & 772 \\
\hline Openph...$\ldots \ldots \ldots \ldots \ldots$ & 10 & 0.130 & 29 & 168 & 0.080 & 208 & 488 & 0.046 & 417 \\
\hline In stau Leaching & 47 & 0.130 & 122 & 131 & 0.078 & 208 & 288 & 0.062 & 301 \\
\hline Onor" ........ & $<1$ & 0.264 & $<1$ & 16 & 0.080 & 18 & 29 & 0.044 & 20 \\
\hline Tow $\ldots \ldots \ldots \ldots \ldots \ldots$ & 83 & 0.178 & 202 & 465 & 0.106 & 082 & 1,130 & 0.068 & 1,611 \\
\hline
\end{tabular}

\section{Wolotied avernos.}

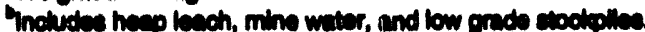

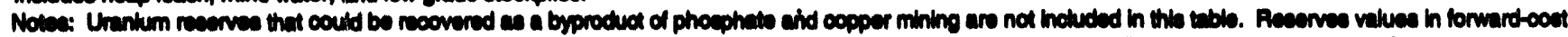

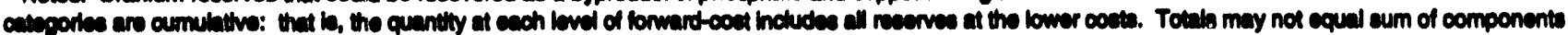
becures of independent rounding.

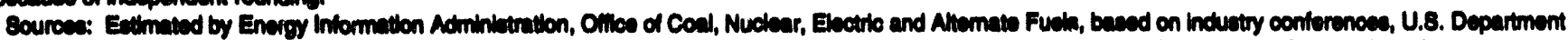

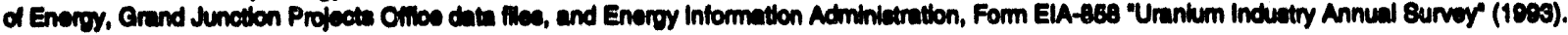

Figure 5. U.8. Reeervee by Mining Mothod at the End of 1993

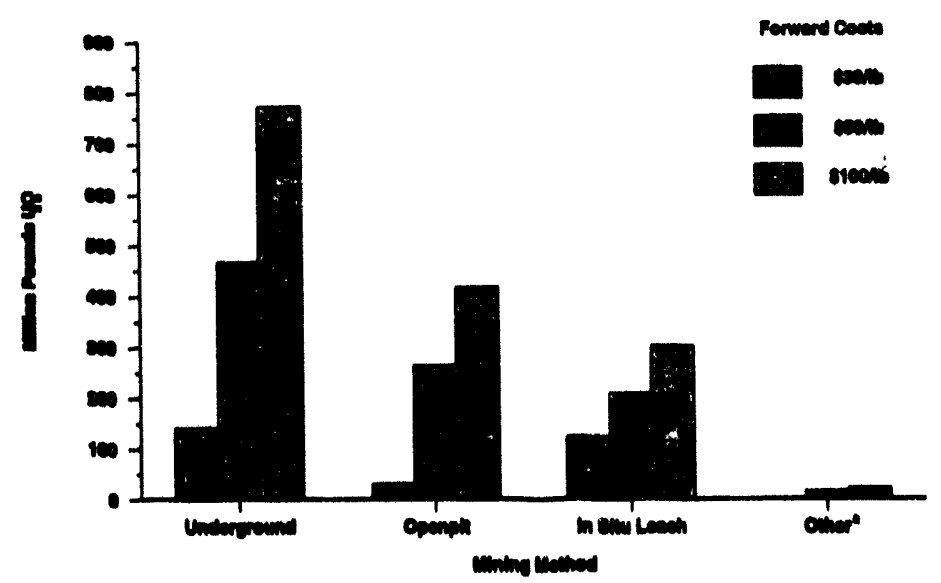

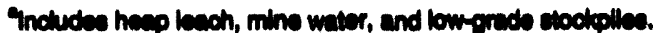

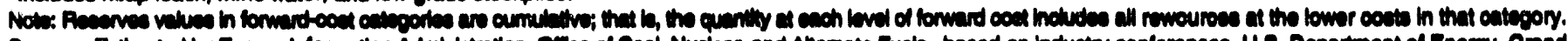

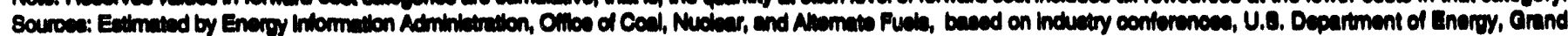

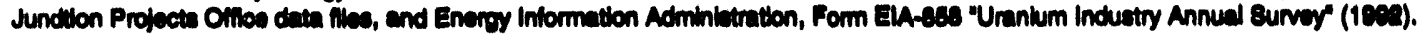


Table 12. U.8. Uranium Mine Production by Mining Method, 1981-1993 (Million pounds $\mathrm{U}_{3} \mathrm{O}_{\text {) }}$ )

\begin{tabular}{|c|c|c|c|c|c|c|c|c|c|c|c|c|c|}
\hline 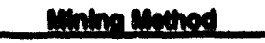 & $1 \mathrm{x}$ & II. & $1 \%:$ & 19 & $1 \mathrm{es}$ & 190 & $19 \pi$ & 100 & 1890 & 1900 & 1001 & 102 & 190 \\
\hline Undereround ........ & 17.0 & 12.6 & (a) & 4.9 & 4.6 & 6.4 & 4.9 & 6.4 & 5.3 & $w$ & $w$ & $w$ & 0 \\
\hline Poreent of Toial .... & 40.4 & $\mathbf{8 5 . 4}$ & - & 49.0 & 52.3 & 77.8 & 81.7 & 56.8 & 54.4 & $w$ & $w$ & $w$ & - \\
\hline Openpin .......... & 14.0 & 7.6 & (a) & 2.8 & 2.0 & $w$ & $w$ & $w$ & $w$ & 1.9 & 2.5 & $w$ & 0 \\
\hline Poreont of Tosd .... & 89.8 & 32.2 & - & 20.0 & 23.3 & $w$ & $w$ & $w$ & $\mathbf{w}$ & 32.0 & 48.8 & $w$ & - \\
\hline Ound .. & 8.6 & 3.4 & 4.9 & 2.2 & 2.1 & 1.8 & 1.1 & 4.1 & 4.4 & 4.0 & 2.7 & 1.0 & 2.0 \\
\hline Porcent of Total .... & 16.3 & 14.4 & 20.0 & 22.0 & 24.4 & 22.2 & 18.3 & 43.2 & 45.6 & 68.0 & 51.2 & 100.0 & 100.0 \\
\hline$\ldots \ldots \ldots \ldots$ & 30.0 & 28.6 & 28.8 & 10.0 & 8.6 & 8.3 & 6.0 & 9.5 & 9.7 & 5.8 & 5.2 & 1.0 & 2.0 \\
\hline Pereent Changs from & & & & & & & & & & & & & \\
\hline Pitry & - & 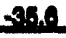 & -0.4 & .074 & -14.0 & 3.5 & $\$ 27.7$ & 5.3 .3 & 2.1 & -392 & -11.8 & +90.7 & 10.5 .1 \\
\hline
\end{tabular}

For 19as, cpenpll plus underground mine production was 18.6 million pounde $U_{3}, O_{1}$, or 79.1 percent.

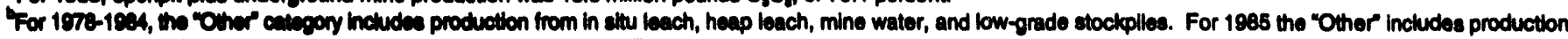
from in elu lach, mine water, and water-treatment plant colitions. For 1983 through 1989, the "Other" includes production from openpit, in situ leach, heap leach, mine

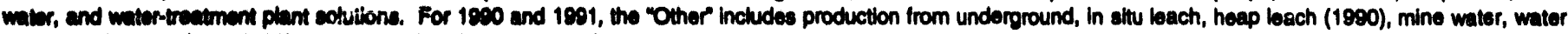

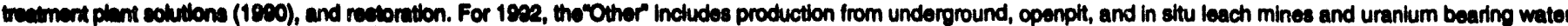

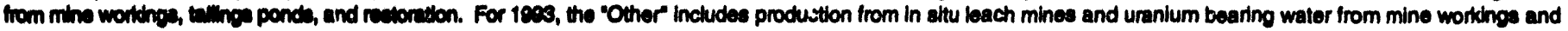
retionition.

- Not eqpilloblo.

$W=$ Whithid to avold declocure of company-epecillo dath. The data are Inchuded in the total for "Other."

Notes: Tocab may not cqual sum of components because of independent rounding. Percentages were calculated using unrounded dath.

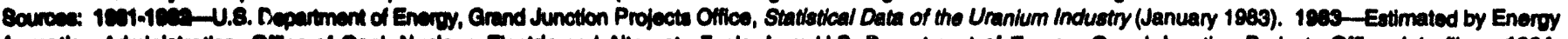

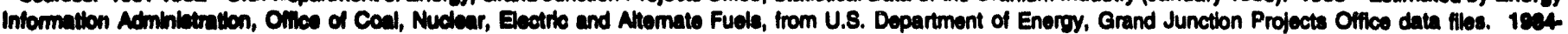

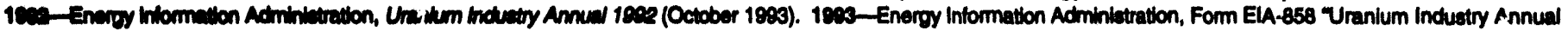
Eurver (1903).

Table 13. Mine Production of Uranium by State, 1968-1993 (Million Pounds $U_{3} O_{\text {) }}$

\begin{tabular}{|c|c|c|c|c|c|c|c|}
\hline Yes & 2010rids & مoxlm Man & Toxe & Uhn & Eromins. & other & Totel \\
\hline $1998-1978 \ldots \ldots \ldots \ldots$ & 16.6 & 138.5 & 1.2 & 10.1 & 92.9 & 51.4 & 310.1 \\
\hline $1970 \ldots \ldots \ldots \ldots \ldots \ldots$ & (D) & 16.4 & (b) & (b) & 11.2 & 13.8 & 41.4 \\
\hline $1980 \ldots \ldots \ldots \ldots \ldots$ & (b) & 16.4 & 7.0 & (b) & 12.8 & 8.2 & 44.4 \\
\hline $1981 \ldots \ldots \ldots \ldots \ldots$ & (b) & 13.2 & 6.4 & (b) & 8.8 & 8.2 & 38.6 \\
\hline $19 a 2 \ldots \ldots \ldots \ldots \ldots$ & (b) & 7.6 & 4.4 & (b) & 5.4 & 6.2 & 23.6 \\
\hline $1093 \ldots \ldots \ldots \ldots \ldots$ & (b) & 6.9 & 3.9 & (b) & 7.4 & 6.3 & 23.5 \\
\hline $1094 \ldots \ldots \ldots \ldots \ldots$ & $w$ & 3.0 & 2.7 & $w$ & 1.9 & 2.4 & 10.0 \\
\hline $1898 \ldots \ldots \ldots \ldots \ldots$ & $w$ & 1.3 & 2.1 & $w$ & 1.6 & 3.5 & 8.6 \\
\hline $1928 \ldots \ldots \ldots \ldots \ldots$ & $w$ & 1.6 & 1.6 & $w$ & $w$ & 5.2 & 8.3 \\
\hline $1997 \ldots \ldots \ldots \ldots \ldots$ & $w$ & 2.0 & 0.9 & $w$ & $w$ & 3.1 & 8.0 \\
\hline $19 a 8 \ldots \ldots \ldots \ldots \ldots$ & $w$ & $w$ & 2.2 & $w$ & 2.0 & 5.3 & 9.5 \\
\hline $1000 \ldots \ldots \ldots \ldots \ldots$ & $w$ & $w$ & 2.8 & $\mathbf{w}$ & 1.4 & 5.4 & 9.7 \\
\hline $1000 \ldots \ldots \ldots \ldots \ldots$ & $w$ & $w$ & 2.0 & w & 1.3 & 2.5 & 5.8 \\
\hline $1001 \ldots \ldots \ldots \ldots \ldots$ & $w$ & $w$ & 2.6 & $w$ & 1.9 & 0.7 & 5.2 \\
\hline $19 m \ldots \ldots \ldots \ldots \ldots$ & $w$ & $w$ & 0.3 & $w$ & 0.2 & 0.5 & 1.0 \\
\hline $199 \%$ & (A) & $(\theta)$ & 0.3 & 0 & 11 & 0.6 & 2,0 \\
\hline
\end{tabular}

Include, for varbus yeam, Alacka, Arizona, Colorado, Now Moxico, Nebraska, North Dakota, South Dakota, Texas, Utah, Washington, and Wyoming.

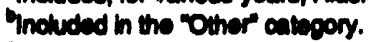

Leev than 0.1 milion pounde $U_{2} O_{3}$

W - Whited to avold duclocure of company-epecilic data. The data are included in the total for "Others."

Nove: Total may not cqual um of components because of independent rounding.

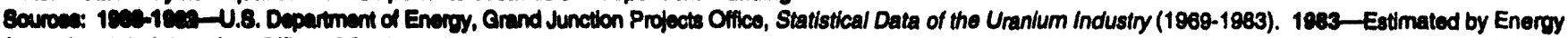

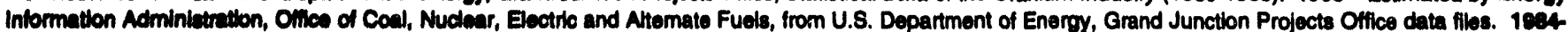
icui_Eney Intormaten Adninietrution, Uranium Industry Annual 1992 (October 1993). 1993-Energy Information Administration, Form ElA-858 Uranlum Industry Annual surver" (1003). 
Figuns 6. Total U.S. Uranium Mine Production, 1968-1993

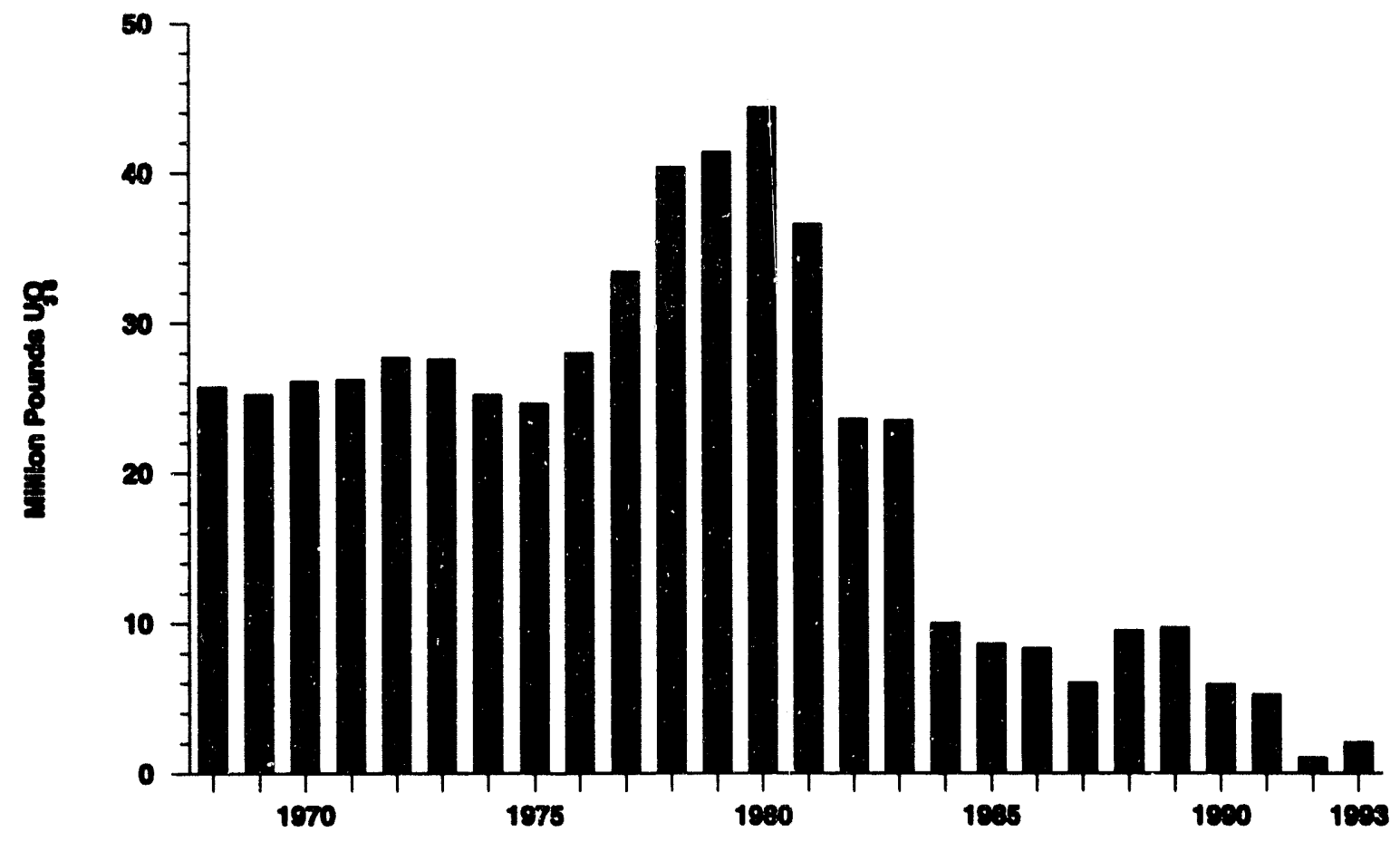

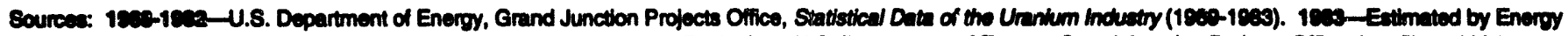

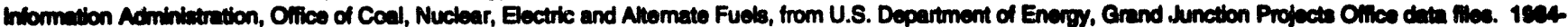

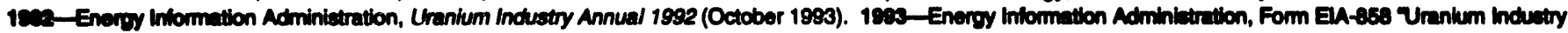
Amuel Surver (1803).

Table 14. Number of U.S. Uranium Mine Operations, 1982-1993

\begin{tabular}{|c|c|c|c|c|c|c|c|c|c|c|c|c|}
\hline Mno Tres & 1892 & 1983 & 1894 & 1985 & 1896 & 1897 & 1890 & 1600 & 1000 & 1001 & $1 e 02$ & 190 \\
\hline Undergound & 139 & 84 & 19 & 13 & 13 & 19 & 17 & 18 & 27 & 6 & 4 & 0 \\
\hline Openpt ......... & 24 & 16 & 8 & 6 & 4 & 2 & 4 & 2 & 2 & 2 & 1 & 0 \\
\hline In Stu Leaching ............ & 18 & 10 & 14 & 10 & 12 & 15 & 11 & 8 & 7 & 6 & 4 & 5 \\
\hline Other...$\ldots \ldots \ldots \ldots \ldots \ldots$ & 10 & 7 & 1 & 5 & 2 & 1 & 0 & 2 & 3 & 1 & 8 & 7 \\
\hline Teer & 191 & 127 & 42 & 34 & 31 & 37 & 32 & 82 & 80 & 18 & 17 & 12 \\
\hline
\end{tabular}

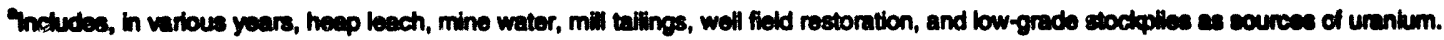
Now: Teble does noi hatudo byproduct sources.

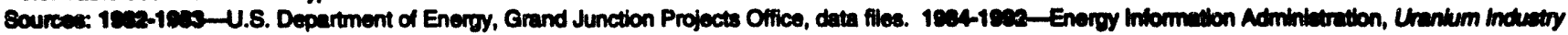
Amud 1802 (October 1993). 1903-Energy Information Administration, Form ElA-658 "Uranlum Industry Annual Surver" (1900).

The quantities of uranium ore produced from openpit and underground mines and received at mills for 1948 through 1992 are shown in Table 15. There were no shipments of uranium ore from mines to uranium mills during 1993. Uranium ore was mined from U.S. deposits every year from $1947^{2}$ through 1992, with 1980 recording the peak year for production, 40 million pounds $\mathrm{U}_{3} \mathrm{O}_{8}$. Data for in situ leach production or miscellaneous production from mine water, heap-leach solution, byproduct recovery, in situ leach well field restoration, or from low grade ore on old mine dumps are not included in Table 15. 
Table 15. Uranlum Ore Produced at U.S. Mines and Recelved at U.S. Mills, 1948-1993

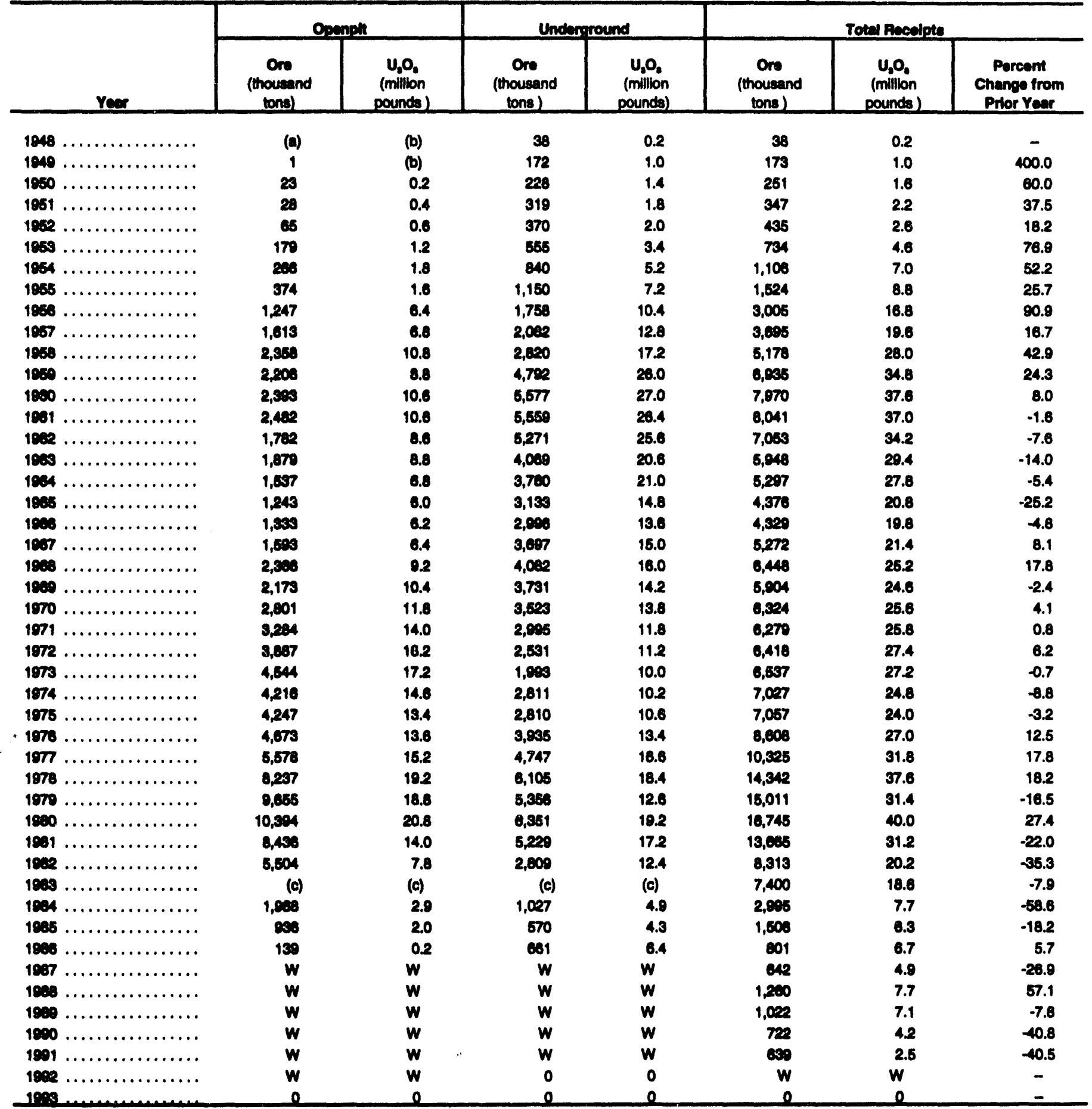

Vulwe to lese than 1,000 bons.

Velus is leas then 0.2 million pounds.

"For 10e9, only loted mine production deta were reported.

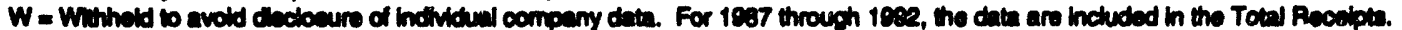

- = Not epplicablo.

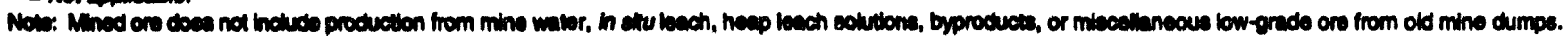

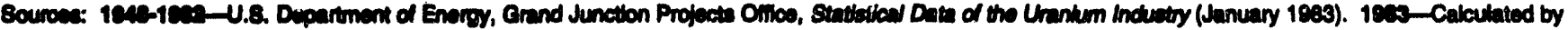

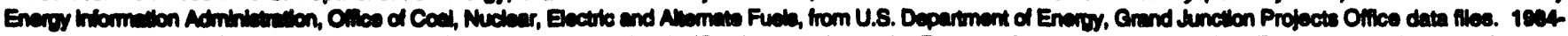

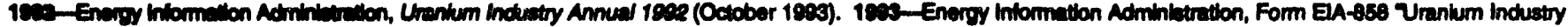
Annuel Burver (1900). 


\section{U.S. Uranium Concentrate Production}

Total U.S. uranium concentrate $\left(\mathrm{U}_{3} \mathrm{O}_{8}\right)$ production in 1993 declined by 46 percent from the 1992 level, primarily because conventional production facilities in Colorado, New Mexico, Utah, and Wyoming remained inactive throughout 1993 and production from the processing of phosphate declined in conjunction with industry realignments. Wyoming was the leading State in uranium concentrate production in 1993 (Table 16). Louisiana, Nebraska, and Texas also were significant States in uranium concentrate production. Compared with
1992, concentrate production in 1993 decreased in Texas by 74 percent, in Wyoming by 25 percent, and in other States by 48 percent.

Concentrate production in Texas and Wyoming in 1993 was from in situ leaching operations and restoration of well-field aquifers. In Nebraska it was from in situ leaching. In New Mexico, production was from processing of mine water. In Louisiana, uranium was recovered as a byproduct of phosphoric acid production. Florida phosphate rock is the raw material used in the production of phosphoric acid.

Table 16. Uranium Concentrate Production by State, 1947-1993 (Million Pounds $\mathrm{U}_{3} \mathrm{O}_{\mathrm{B}}$ )

\begin{tabular}{|c|c|c|c|c|c|c|c|c|}
\hline \multirow[b]{2}{*}{ Yenclol } & \multicolumn{6}{|c|}{ Stote } & \multirow[b]{2}{*}{ Total } & \multirow{2}{*}{$\begin{array}{c}\text { Cumulative } \\
\text { Toth }\end{array}$} \\
\hline & Colorado & Moxico & Texas & Utah & Wyoming & Other & & \\
\hline 1847-1889 . . . & 71.414 & 154.890 & (b) & 57.848 & 58.600 & 28.298 & 371.050 & $1,621.980$ \\
\hline $1970 \ldots \ldots$ & (c) & 11.542 & (b) & (c) & 7.308 & 6.960 & 25.810 & 396.860 \\
\hline $1971 \ldots \ldots \ldots$ & (c) & 10.610 & (b) & (c) & 6.974 & 6.962 & 25.546 & 421.406 \\
\hline $1872 \ldots \ldots \ldots$ & (c) & 10.928 & (b) & (c) & 8.432 & 6.440 & 25.800 & 447.206 \\
\hline $1973 \ldots \ldots \ldots$ & (c) & 9.268 & (b) & (c) & 10.318 & 6.884 & 26.470 & 473.676 \\
\hline $1874 \ldots \ldots \ldots$ & (c) & 9.902 & (b) & (c) & 7.534 & 5.620 & 23.056 & 486.732 \\
\hline $1875 \ldots \ldots \ldots \ldots$ & (c) & 10.382 & (c) & (c) & 6.894 & 5.924 & 23.200 & 518.932 \\
\hline $1976 \ldots \ldots \ldots$ & (c) & 12.118 & (c) & (c) & 8.092 & 5.284 & 25.494 & 545.426 \\
\hline $1977 \ldots \ldots \ldots$ & (c) & 13.558 & (c) & (c) & 9.980 & 6.340 & 29.878 & 575.304 \\
\hline $1978 \ldots \ldots \ldots$ & (c) & 17.078 & (c) & (c) & 10.658 & 9.236 & 36.972 & 612.276 \\
\hline $1879 \ldots \ldots \ldots$ & (c) & 14.846 & 5.302 & (c) & 10.804 & 6.420 & 37.472 & 649.748 \\
\hline $1880 \ldots \ldots \ldots$ & (c) & 15.502 & 6.816 & (c) & 12.072 & 9.314 & 43.704 & 693.452 \\
\hline $1881 \ldots \ldots \ldots$ & (c) & 12.412 & 6.282 & (c) & 8.170 & 11.070 & 38.474 & 731.826 \\
\hline $1882 \ldots \ldots \ldots$ & (c) & 7.812 & 4.262 & (c) & 5.042 & 9.752 & 26.868 & 758.794 \\
\hline $1880 \ldots \ldots$ & $w$ & 5.660 & 3.200 & $\mathbf{W}$ & 5.260 & 7.038 & 21.158 & 779.852 \\
\hline $1884 \ldots \ldots \ldots$ & $\mathbf{W}$ & 2.916 & 2.620 & $\mathbf{W}$ & 3.120 & 6.226 & ${ }_{14.882}$ & 794.834 \\
\hline $1805 \ldots \ldots \ldots$ & $\mathbf{W}$ & 1.387 & 2.167 & $\mathbf{W}$ & 2.427 & 5.333 & $d_{11.314}$ & 808.148 \\
\hline $1888 \ldots \ldots \ldots$ & $\mathbf{W}$ & 0.751 & 2.586 & $\mathbf{W}$ & 0.633 & 9.536 & $d_{13.506}$ & 819.654 \\
\hline $1987 \ldots \ldots \ldots$ & $\mathbf{W}$ & 0.700 & 2.716 & $\mathbf{w}$ & 0.567 & 9.008 & ${ }^{d} 12.991$ & 832.645 \\
\hline $1888 \ldots \ldots \ldots$ & $\mathbf{W}$ & $\mathbf{W}$ & 2.805 & $\mathbf{W}$ & 2.007 & 8.318 & 13.130 & 845.775 \\
\hline $1889 \ldots \ldots \ldots$ & 0 & $\mathbf{W}$ & 2.939 & $\mathbf{W}$ & 1.607 & 9.291 & 13.837 & 859.612 \\
\hline $1880 \ldots \ldots \ldots$ & 0 & $\mathbf{W}$ & 1.832 & $\mathbf{W}$ & 1.368 & 5.685 & $\mathbf{8 . 8 8 5}$ & 868.497 \\
\hline $1891 \ldots \ldots \ldots$ & 0 & $\mathbf{W}$ & 2.343 & 0 & 2.035 & 3.574 & 7.952 & 876.449 \\
\hline $1892 \ldots \ldots \ldots$ & 0 & $\mathbf{W}$ & 1.032 & 0 & 1.589 & 3.024 & 5.645 & 882.094 \\
\hline 1990 & 0 & $w$ & 0.2699 & 0 & 1.190 & 1,603 & 3.063 & 88.5 .157 \\
\hline
\end{tabular}

Inchudes, for various yoars, Arizone, Colorado, Florida, Loulalana, Nebracke, Now Maxico, South Dakota, Toxas, Utah, and Washington.

Dontin mere not collected.

Inchuded in the "Other category.

Total does not include uranium concentrate production from pilot projects or other reacarch project ecurces.

$W$ = Whitheld to avoid diecloaure of inclidiual company data. The data are inctuded in "Other."

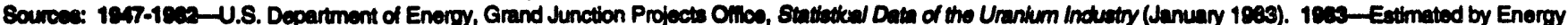
Information Adininistration, Oriice of Coal, Nuclear, Electric and Aternate Fuels, from U.8. Depaiment of Energy, Crand Junction Projects Oilice data files. 19e4

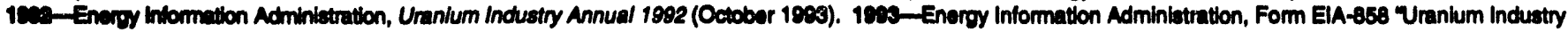
Amual Eunver (1023). 
Statistics on total U.S. uranium processing operations for uranium concentrate production for 1983 through 1993 are shown in Table 17. Between 1989 and 1993, production has ranged from 13.8 million pounds to 3.1 million pounds $\mathrm{U}_{3} \mathrm{O}_{8}$. There was no uranium concentrate production from conventional milling of uranium ore in 1993, however, a small amount of uranium was recovered from mine water processing. Production from "Other" sources (other than from mined ore) was 3.0 million pounds, about 1.3 million pounds less than in 1992, and it represented 99 percent of total production in 1993. Since 1987, production from "Other" sources has accounted for a steadily increasing share of total domestic production, as the number of operating conventional mills

Table 17. U.S. Uranlum Processing Operations, 1983-1993

\begin{tabular}{|c|c|c|c|c|c|c|c|c|c|c|c|}
\hline Provecaln. Operrition & 10.3 & 1094 & 1895 & $1 \mathrm{eas}$ & 1897 & 189 & 1990 & 1900 & 1801 & 1892 & 1893 \\
\hline \multicolumn{12}{|l|}{ Oro Fod to Process" } \\
\hline (thousand tons ore) ... & 5,825 & 4,316 & 1,785 & 1,308 & 1,441 & 1,214 & 1,235 & 722 & 639 & 258 & 0 \\
\hline$(\operatorname{grad})^{b}, \ldots \ldots \ldots \ldots$ & 0.128 & 0.112 & 0.161 & 0.388 & 0.284 & 0.288 & 0.328 & 0.298 & 0.188 & 0.229 & - \\
\hline (milion pounds $U_{2} O_{0}$ ) .. & 15.180 & 9.681 & 5.785 & 8.783 & 8.181 & 6.898 & 7.977 & 4.227 & 2.529 & 1.171 & 0 \\
\hline \multicolumn{12}{|l|}{ Other MIM Feed" } \\
\hline (milion pounds $U_{9} O_{j}$ ) .. & 0.573 & 0.588 & 0.750 & 0.280 & 0.474 & 0.507 & 0.429 & 0.485 & 0.179 & 0.181 & 0.042 \\
\hline \multicolumn{12}{|l|}{ Total Mill Food } \\
\hline (million pounds $U_{3} O_{1}$ ) & 15.752 & 10.168 & 6.585 & 8.043 & 8.684 & 7.505 & 8.408 & 4.712 & 2.708 & 1.353 & 0.042 \\
\hline \multicolumn{12}{|l|}{ In-Process Inventory Change } \\
\hline (million pounds $U_{2}, O_{2}$ ) .. & -0.280 & 0.048 & 0.208 & -0.004 & -0.210 & 0.138 & -0.234 & -0.244 & -0.122 & -0.025 & 0.010 \\
\hline \multicolumn{12}{|l|}{$\begin{array}{c}\text { Concentrate Production } \\
\text { (milition pounds } \mathrm{U}_{2} \mathrm{O}_{\downarrow} \text { ) }\end{array}$} \\
\hline Theoretical Production ${ }^{d}$ & 16.082 & 10.119 & 6.329 & 9.107 & 8.874 & 7.839 & 8.640 & 4.958 & 2.880 & 1.377 & 0.031 \\
\hline \multicolumn{12}{|l|}{ Tallnge Leas } \\
\hline Uneccountables ..... & 0.514 & 0.493 & 0.245 & 0.254 & 0.388 & 0.385 & 0.465 & 0.309 & 0.222 & 0.018 & 0.001 \\
\hline \multicolumn{12}{|l|}{ Recovery From Mill Feed } \\
\hline (percent) $\ldots \ldots \ldots \ldots$ & 98.8 & 95.1 & 88.1 & 97.2 & 86.2 & 95.5 & 94.6 & 99.8 & 92.2 & 98.7 & - \\
\hline Other Processing .... & 5.689 & 5.268 & 5.250 & 4.658 & 4.465 & 6.088 & 5.662 & 4.237 & 5.344 & 4.288 & 3.083 \\
\hline Total Production ...... & 21.158 & $t_{14.882}$ & '11.314 & $t_{13.508}$ & $1 / 2.891$ & 13.130 & 13.837 & 8.885 & 7.952 & 5.645 & 3.083 \\
\hline \multicolumn{12}{|l|}{ Concentrate Shipments } \\
\hline (miliron pounds $U_{2} O_{\alpha}$ ) . . & 18.755 & 16.485 & 11.760 & 10.841 & 11.558 & 12.791 & 14.808 & 12.857 & 8.437 & 6.853 & 3.374 \\
\hline
\end{tabular}

Umanium ore fed to procese" in any yoar can includs: ore mined and shipped to a mill during the same year, ore that was mined during a prior year and later shipped from mine-elte stockplles, and/or ore obtained from draudowns of stockplies maintained at a mill site.

Woighted average percent $\mathrm{U}_{2} \mathrm{O}_{\mathrm{s}}$.

Includes uranium from low-grade ore, mine water, thilinges water, and heap leaching, except as footnoted below.

At 100-percent recovery.

$\mathrm{U}, \mathrm{O}$, concentrate production from in stu leaching and as a byproduct of other proceseing. The totals for 1896 and following years include $\mathrm{U}, \mathrm{O}$, recovered from rectamation and mine water at some mills that did not report procesaing of uranium ore for those yoars.

'Total does not Include uranium concentrate production from pllot projects or other research project eources.

- = Not applleable

Note: Totals may not equal sum of components because of independent rounding.

Sources: 1900-1ese-Calculated by Eneroy Information Adminiatution, Olice of Coal, Nuctear, Electric and Altemate Fuels, from U.S. Department of Enorgy, Grand Junction Projects Ofilice data files. 1es4-18es_Energy Information Adminictration, Uranium Industry Annual 1892 (October 1993). 1893 -Energy Information Administration, Form ELA-868, Urankum Industry Annual Burver" (1893). 
has steadily declined. The "Other" sources for 1993 include in situ leaching, byproduct, and mine water. Annual uranium concentrate production for 1955 through 1993 is shown in Figure 7.

The byproduct uranium recovery industry began in the United States in 1977, and the annual share of domestic uranium concentrate derived from wet-process phosphoric acid production has been significant. Byproduct uranium concentrate production is not shown separately in Table 16 to avoid disclosure of proprietary data.

Shipments of U308 concentrate from domestic production facilities was 3.4 million pounds in 1993 com-

Figure 7. U.S. Production of Uranium Concentrate, 1955-1993

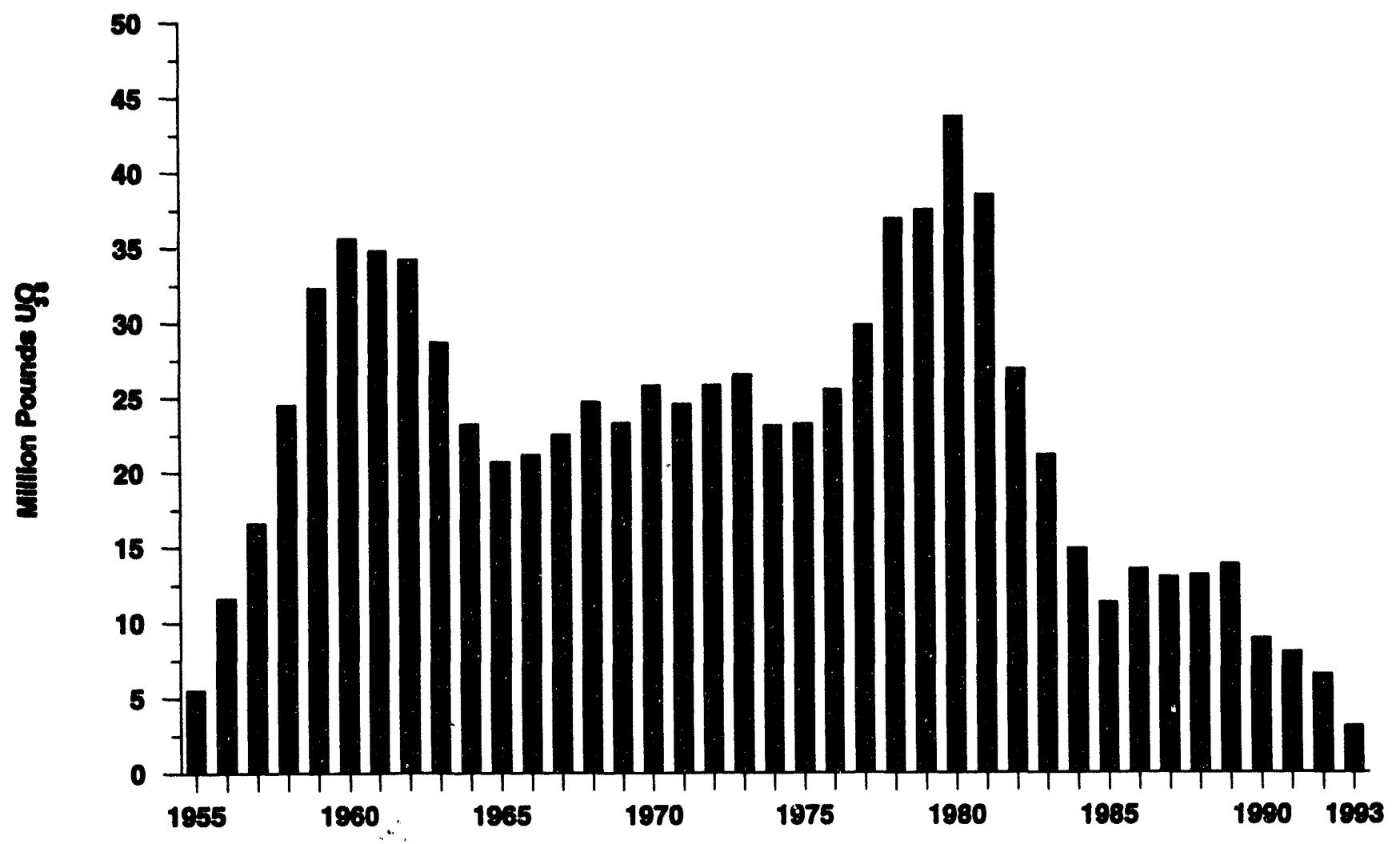

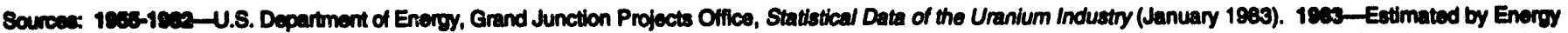
Information Adninietration, Ofice of Coal, Nuctear, Electric and Attemate Fuels, from U.S. Department of Energy, Grand Junction Projects Oifice data files. 1Ca4

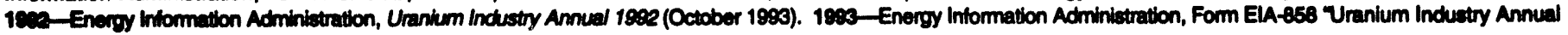
Eunuy (18:3).

pared with 6.9 million pounds in 1992 (Table 17). Concentrate shipments reported in 1993 by producers were approximately 0.3 million pounds above the total domestic $\mathrm{U}_{3} \mathrm{O}_{8}$ production for the year. This resulted in an overall decrease in concentrate inventories held at production facilities at the end of 1993. Annual shipments of concentrate from processing plants in 1989 through 1993 exceeded annual concentrate production in those years. 
At the end of 1993, two phosphate byproduct and five in situ leaching plants were in operation (Table 18), with acombined rated capacity of 10.9 million pounds $\mathrm{U}_{3} \mathrm{O}_{8}$ per year. At the end of 1993, there were six inactive U.S. conventional uranium mills with a combined rated capacity of 14,650 tons of ore per day, (Tables 19).

Table 18. Operating Status of U.S. Nonconventional Uranium Plants, 1993

\begin{tabular}{|c|c|c|c|c|}
\hline Plent Oumer & $\begin{array}{l}\text { Name } \\
\text { and State }\end{array}$ & Plant Type & $\begin{array}{c}\text { Rated Capaclty } \\
\text { (thousand pounds } \\
U_{3}, 0 \text {, per year) }\end{array}$ & $\begin{array}{l}\text { Operating status } \\
\text { at the End } \\
\text { of the Year }\end{array}$ \\
\hline Converse County Mining Venture ..... & Highland (WY) & In Situ Leach & 2,000 & 0 \\
\hline COCEMA Mining, Inc. . . . . . . . . . & West Cole (TX) & In Situ Leach & 200 & 1 \\
\hline Everest Minerals .............. & Hobson (TX) & In Situ Leach & 1,000 & $\mathbf{I}$ \\
\hline Ferrot Exploration of Nebraska ....... & Crow Butte (NE) & In Situ Leach & 1,000 & 0 \\
\hline IMC-Agrico Company $\ldots \ldots \ldots \ldots$ & Sunshine Bridge (LA) & Phosphate Byproduct & 420 & 0 \\
\hline IMC-Agrico Company $\ldots \ldots \ldots \ldots \ldots$ & Uncle Sam (LA) & Phosphate Byproduct & 750 & 0 \\
\hline IMC-Agrico Company $\ldots \ldots \ldots \ldots \ldots$ & Plant Clty (FL) & Phosphate Byproduct & 608 & 1 \\
\hline IMC-Agrico Company $\ldots \ldots \ldots \ldots$ & Now Wales (FL) & Phosphate Byproduct & 750 & 1 \\
\hline Malapel Resources $\ldots \ldots \ldots \ldots$ & Christensen Ranch (WY) & In Situ Leach & 650 & 0 \\
\hline Malapal Resources $\ldots \ldots \ldots \ldots \ldots$ & Hollday-El Mesquite (TX) & In Situ Leach & 634 & $\mathbf{0}$ \\
\hline Malapal Resources $\ldots \ldots \ldots \ldots \ldots$. & Irgaray (WY) & In Situ Leach & 350 & 0 \\
\hline Rlo Algom Mining Company . . . . . . . & Smith Ranch (WY) & In Situ Leach & 250 & 1 \\
\hline Uranlum Resources, Inc. . . . . . . . . & Kingoville Dome (TX) & In Situ Leach & 1,300 & 1 \\
\hline Uranium Resources, Inc. . . . . . . . . . & Rosita (TX) & In Situ Leach & 1,000 & $\mathbf{I}$ \\
\hline
\end{tabular}

$O=$ Operating at the end of the year, $I=$ inactive at the end of the year.

Note: Pathinder Mines, Inc. has been granted a commercial license for its North Butte-Ruth in situ leach project in Campbell County, Wyoming. Sources: Energy Information Administration, Form EiA-858 Uranium Industry Annual Survey" (1993). Energy Information Administration, "Uranium In Situ Leach Mining in the United States," in Uranium Industry Annual 1993, DOE/EIA-0478(93) (September 1994) (Washington, DC) pP vill-xxlv. 
Table 19. Operating Status of U.S. Conventional Uranium Mills, 1987-1993

\begin{tabular}{|c|c|c|c|c|c|c|c|c|c|}
\hline \multirow[b]{2}{*}{ Mill Owner } & \multirow{2}{*}{$\begin{array}{l}\text { Name and } \\
\text { State }\end{array}$} & \multirow{2}{*}{$\begin{array}{l}\text { Milling } \\
\text { Capacity } \\
\text { (short tons of } \\
\text { ore per day) }\end{array}$} & \multicolumn{7}{|c|}{ Operating Status at the End of the Year } \\
\hline & & & 1987 & 1988 & 1989 & 1990 & 1991 & 1992 & 1993 \\
\hline American Nuclear $\ldots \ldots \ldots \ldots$ & Gas Hills(WY) & $(950)$ & 1 & D & D & D & D & D & D \\
\hline Atlas Minerals $\ldots \ldots \ldots \ldots \ldots$ & Moab (UT) & $(1,400)$ & $\mathbf{I}$ & D & D & D & D & D & D \\
\hline Cotter $\ldots \ldots \ldots \ldots \ldots \ldots \ldots$ & Canon City (CO) & 1,200 & 9 & 1 & 1 & 1 & 1 & 1 & 1 \\
\hline Dawn Mining $\ldots \ldots \ldots \ldots \ldots$ & Ford (WA) & 450 & 1 & 1 & 1 & 1 & 1 & 1 & 1 \\
\hline $\begin{array}{l}\text { Homestake Mining } \ldots \ldots \ldots \ldots \\
\text { Green Mountaln Mining }\end{array}$ & Grants (NM) & $(3,400)$ & 0 & 0 & 0 & 1 & D & D & D \\
\hline Venture $\ldots \ldots \ldots \ldots \ldots \ldots$ & Sweetwater $(W Y)^{d}$ & 3,000 & 1 & 1 & 1 & 1 & 1 & 1 & 1 \\
\hline Pathfinder Mines . . . . . . . . . . & Lucky Mc (WY $)^{d}$ & $(2,800)$ & 0 & 1 & 1 & 1 & $\mathbf{P}$ & D & D \\
\hline Pathifinder Mines ............ & Shirtey Basin (WY) & $(1,800)$ & 0 & 9 & 9 & 0 & 0 & D & D \\
\hline Plateau Resources $\ldots \ldots \ldots \ldots$ & Shootering (UT) & 1,000 & 1 & 1 & 1 & 1 & 1 & 1 & 1 \\
\hline Rilo Algom Mining . . . . . . . . . . & Ambrosia Lake (NM) & 7,000 & 1 & 1 & 1 & 1 & 1 & 1 & 1 \\
\hline Rlo Algom Mining $\ldots \ldots \ldots \ldots$ & Llabon $(U T)^{d}$ & (750) & 0 & 9 & 1 & 1 & 1 & $\mathbf{P}$ & $\mathbf{P}$ \\
\hline $\begin{array}{l}\text { Rlo Grande Resources } . . . . \ldots \\
\text { Umetco Mineral\& Energy }\end{array}$ & Panna Maria (TX) & $(3,000)$ & 0 & 0 & 0 & 0 & 0 & D & D \\
\hline Fuels Nuclear . . . . . . . . . . . & White Mesa (UT) ${ }^{d}$ & 2,000 & 0 & 0 & 0 & 9 & 1 & 1 & 1 \\
\hline Umetco Minerals $\ldots \ldots \ldots \ldots$ & Gas Hills $(W Y)^{d}$ & $(1,300)$ & 1 & 1 & 1 & 1 & D & D & D \\
\hline Umetco Minerals . .......... & Uravan (co) & $(1,400)$ & 1 & 1 & 1 & 1 & $\mathbf{P}$ & $\mathbf{P}$ & $\mathbf{P}$ \\
\hline Western Nuclear $\ldots \ldots \ldots \ldots$. & Split Rock( $W \eta^{d}$ & $(1,700)$ & 1 & D & D & D & D & D & D \\
\hline Western Nuclear $\ldots \ldots \ldots \ldots$. & Sherwood (WA) & $(2,000)$ & 1 & 1 & 1 & 1 & $\mathbf{P}$ & $\mathbf{P}$ & $\mathbf{P}$ \\
\hline
\end{tabular}

Miling capacity based on historical data and data reported on Form ElA-858 for 1992 . Parentheses indicate mills that have been decommissioned of that were permanently closed as of the end of 1993.

bo, Operating throughout the year, I, Inactive at the end of the year, P, Permanently closed as of the end of the year, D, Decommisaloning: Restoration begun or completed.

Inactive at the end of the year but produced during one or more months of the period.

The following mills were isentified in previously published verilons of this thble by location (within the parentheses): Sweetwater (Red Desert, WM);

Lucky Mc (Gas Hills, WM); Shootering (Ticaboo, UT); Ambroeda Lako (Grunts, NM); Llebon (LaSal, UT); White Mosa (Blanding, UT); Gas Hills (Netrona, WM; Split Rock (Jeffrey Cly, WM; and Shenwood (Wolplint, WA).

"Capacty for yoars 1987-1890 was reported as 2,500 tons per day.

Sources: 1987-1992-Energy Information Administration, Uranium Induatry Annual 1892 (October 1993). 19es_-Energy Information Administration, Form EIA-658 Uranlum Industry Annuel Survey' (1893). 
None of the six mills were processing ore at the end of 1993, and no ore was fed-to-process during the year (Table 20). At one mill, uranium was recovered from mine water processing. The year-end status (active or inactive) of nonconventional plants and conventional mills as of December 31, 1993 and their locations are shown in Figure 8.

Table 20. Status of U.S. Conventional Uranlum Milla, 1987-1993

\begin{tabular}{|c|c|c|c|c|c|c|c|}
\hline tem & 1097 & 199 & 1890 & 1000 & 1901 & 1092 & 1803 \\
\hline \multicolumn{8}{|l|}{ Number of Milles } \\
\hline Operating $\ldots \ldots \ldots \ldots \ldots \ldots \ldots \ldots$ & 6 & 3 & 3 & 2 & 2 & 0 & 0 \\
\hline 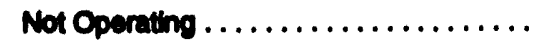 & 11 & 11 & 11 & 12 & 7 & 6 & 6 \\
\hline Total $\ldots \ldots \ldots \ldots \ldots \ldots \ldots \ldots$ & 17 & 14 & 14 & 14 & 9 & 6 & 6 \\
\hline \multicolumn{8}{|l|}{$\begin{array}{l}\text { Mming Capactly } \\
\text { (tone of ore per day) }\end{array}$} \\
\hline Openattng...$\ldots \ldots \ldots \ldots \ldots \ldots \ldots$ & 13,250 & 7,800 & 7,800 & 4,300 & 4,600 & $\mathbf{0}$ & 0 \\
\hline 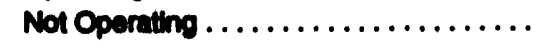 & 21,400 & 22,700 & 22,700 & 28,300 & 15,400 & 14,650 & 14,650 \\
\hline Total $\ldots \ldots \ldots \ldots \ldots \ldots \ldots \ldots \ldots$ & 34,650 & 30,600 & 30,600 & 30,600 & 20,200 & 14,650 & 14,650 \\
\hline $\begin{array}{l}\text { Average Dally Mum Feed } \\
\text { (tone of ore per day) } \ldots \ldots \ldots \ldots \ldots \ldots\end{array}$ & 4,120 & 3,470 & 3,530 & 2,060 & 1,830 & 730 & 0 \\
\hline $\begin{array}{l}\text { Operating Level As Percent } \\
\text { of Total numing Cepacthy ............ }\end{array}$ & 12 & 11 & 12 & 7 & 10 & 5 & 0 \\
\hline
\end{tabular}

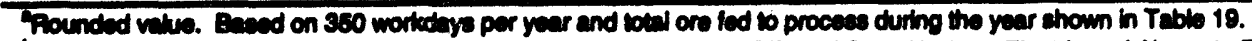

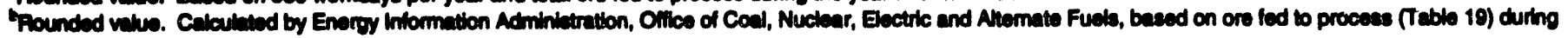
300 wortedaye per year.

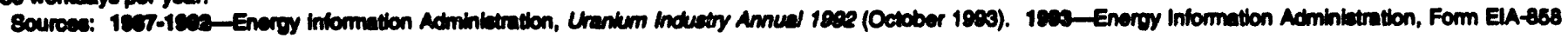
Urentum induetry Annual Burver' (1003). 
Figure 8. Major U.8. Uranlum Reserve Areas and Statue of Mille and Plante, 1993

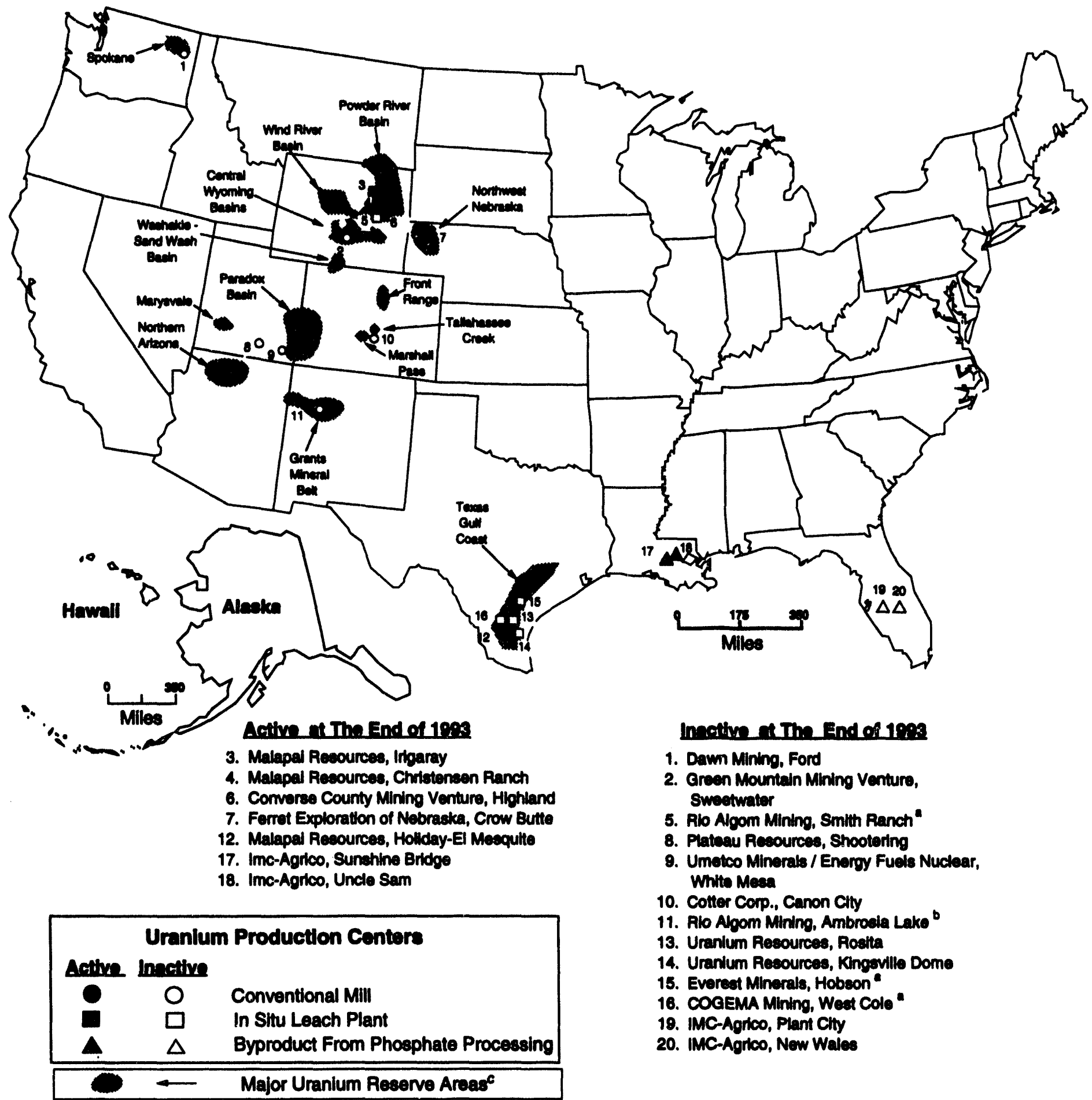

\footnotetext{
Precovered urankum by proceseing water from in stu bech mine reatoration during 1898.

Becovered uranium by proceseling mine water from conventional mines during 1903.

"Mator areas containing reasonably aceured resources at 850-per-pound $\mathrm{U}_{3} \mathrm{O}_{8}$ or leses.

8ources: Based on U.8. Department of Energy, Grand Junction Project Olitice (QJPO), National Uranium Rescurce Eveluation, Intorim Report (June 1979)

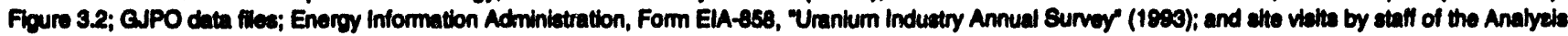
and Syateme Division, Ofice of Coal, Nuctoar, Electric and Alemate Fuels.
} 


\section{Employment in the Uranium Raw Materials Industry}

Employment in the U.S. uranium raw materials industry in 1993 was reported as 380 person-years, a decrease 44 of percent from the 1992 total (Table 21 and Figure 9). Employment levels for exploration declined by 30 per- cent, for mining by 39 percent, for milling by 49 percent, and for processing by 49 percent. Except for 1988, employment in the raw materials sector has declined each year since 1979 when the industry employment was reported as 21,521 person years. The 1993 employment level in the raw materials sector is the lowest since before 1967.

Table 21. Employment in the U.S. Uranium Induetry by Category, 1967-1993 (Person-Yoars)

\begin{tabular}{|c|c|c|c|c|c|c|}
\hline \multirow[b]{2}{*}{ Year } & \multicolumn{4}{|c|}{ Emplorment Coterorles } & \multirow[b]{2}{*}{ Total } & \multirow{2}{*}{$\begin{array}{c}\text { Percent } \\
\text { Change from } \\
\text { Prlor Year }\end{array}$} \\
\hline & Explorition & Mlning & Mulling & Proceneln & & \\
\hline $1997 \ldots \ldots \ldots \ldots \ldots \ldots \ldots \ldots \ldots$ & 1,291 & 3,798 & 1,682 & NA & 6,751 & -- \\
\hline $1988 \ldots \ldots \ldots \ldots \ldots \ldots \ldots \ldots$ & 2,188 & 4,440 & 1,717 & NA & 8,355 & 23.8 \\
\hline $1969 \ldots \ldots \ldots \ldots \ldots \ldots \ldots \ldots$ & 2,632 & 4,702 & 1,725 & NA & 9,059 & 8.4 \\
\hline $1971 \ldots \ldots \ldots \ldots \ldots \ldots \ldots \ldots$ & 1,508 & 4,218 & 1,649 & NA & 7,373 & -9.7 \\
\hline $1972 \ldots \ldots \ldots \ldots \ldots \ldots \ldots \ldots$ & 1,152 & 3,721 & 1,530 & NA & 6,403 & -13.2 \\
\hline $1973 \ldots \ldots \ldots \ldots \ldots \ldots \ldots \ldots$ & 1,657 & 3,516 & 1,522 & NA & 6,595 & 3.0 \\
\hline $1974 \ldots \ldots \ldots \ldots \ldots \ldots \ldots \ldots$ & 1,697 & 3,928 & 1,688 & NA & 7,283 & 10.6 \\
\hline $1975 \ldots \ldots \ldots \ldots \ldots \ldots \ldots \ldots$ & 2,049 & 5,386 & 2,237 & NA & 9,672 & 32.6 \\
\hline $1976 \ldots \ldots \ldots \ldots \ldots \ldots \ldots$ & 2,793 & 7,092 & 2,727 & 511 & 13,123 & 36.7 \\
\hline $1980 \ldots \ldots \ldots \ldots \ldots \ldots \ldots \ldots$ & 3,370 & 11,768 & 3,251 & 1,530 & 19,919 & -7.4 \\
\hline $1881 \ldots \ldots \ldots \ldots \ldots \ldots \ldots \ldots$ & 2,300 & 7,473 & 2,367 & 1,636 & 13,676 & -31.3 \\
\hline $1882 \ldots \ldots \ldots \ldots \ldots \ldots \ldots \ldots$ & 769 & 5,057 & 1,856 & 1,185 & 8,867 & -34.4 \\
\hline $1983 \ldots \ldots \ldots \ldots \ldots \ldots \ldots \ldots$ & 374 & 2,784 & 1,518 & 829 & 5,615 & -37.4 \\
\hline $1884 \ldots \ldots \ldots \ldots \ldots \ldots \ldots \ldots$ & 235 & 1,675 & 987 & 700 & 3,597 & -35.9 \\
\hline $1985 \ldots \ldots \ldots \ldots \ldots \ldots \ldots$ & 163 & 1,212 & 514 & 657 & 2,446 & -32.0 \\
\hline $1886 \ldots \ldots \ldots \ldots \ldots \ldots \ldots \ldots$ & 162 & 954 & 513 & 490 & 2,120 & -13.3 \\
\hline $1987 \ldots \ldots \ldots \ldots \ldots \ldots \ldots \ldots$ & 183 & 819 & 432 & 568 & 2,002 & -5.6 \\
\hline $1988 \ldots \ldots \ldots \ldots \ldots \ldots \ldots \ldots$ & 144 & 849 & 572 & 576 & 2,141 & 6.9 \\
\hline $1989 \ldots \ldots \ldots \ldots \ldots \ldots \ldots \ldots$ & 86 & 659 & 367 & 471 & 1,583 & -26.1 \\
\hline $1990 \ldots \ldots \ldots \ldots \ldots \ldots \ldots$ & 73 & 664 & 304 & 293 & 1,335 & -15.7 \\
\hline
\end{tabular}

Does not inctude 491 person years in 1993 for employment in rectamation work relating to exploration, mining, milling, and proceselng. The collection of employment dath for the rectamation category was initated on the 1980 "Uranium Induetry Annual 8urvey" (Form ElA-858).

$-=$ Not applicable.

NA = Not avilable.

Note: Totala may not equal sum of components because of independent rounding.

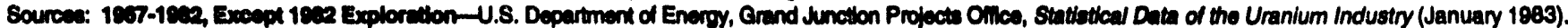

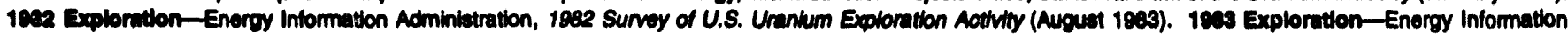

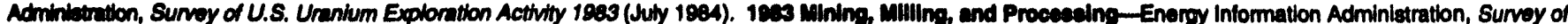

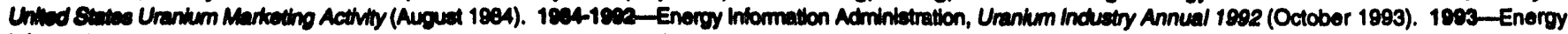
Intormation Adriniatrition, Form ELA-858 "Uranium Industry Annual Survor" (1890). 
Figure 9. Employment in the Uranium Industry, 1967-1993

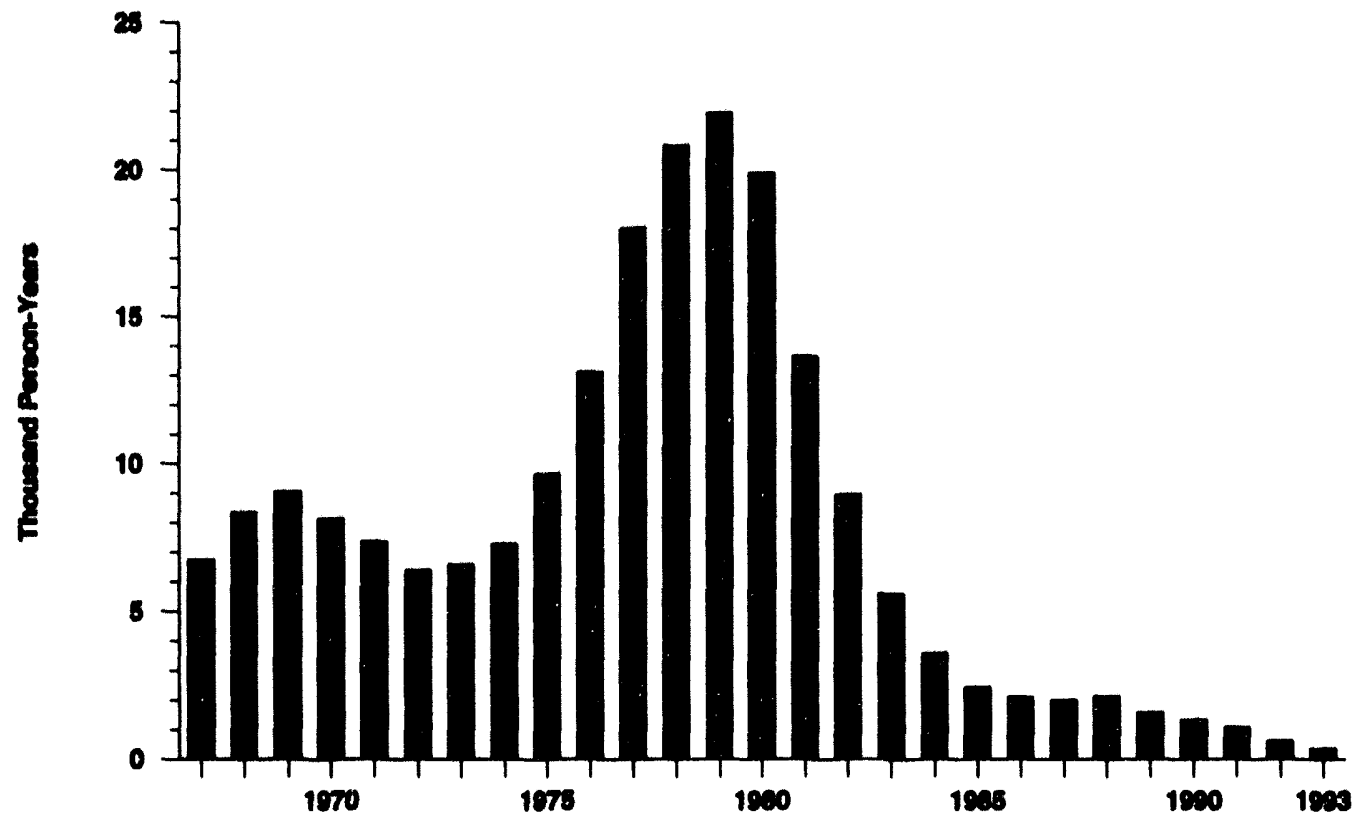

Note: For 1983, does not include 491 person years for employment in rectamation work relating to exploration, mining, miming, and procesaing. The collection of employment datin for the rectamation category was initiated on the 1982 "Unanium Inctustry Annual Surver" (Form EIA-868).

Sources: 1897-1es_-U.S. Department of Energy, Grand Junction Projects Ofilice, Statiatical Datu of the Uranim Industry (January 18es). Energy Intomation

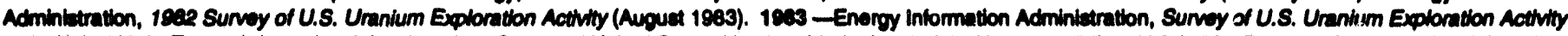

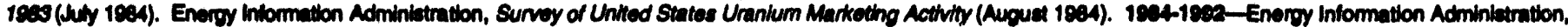
Uhanium industry Annual 1992 (October 1993). 19es-Energy Intormation Administration, Form ElA-858 Uranium Induetry Annual Surver (1893).

Wyoming, Colorado, and Texas accounted for 62 percent of employment in the raw materials sector (Table 22, Figure 10). Florida, Louisiana, and Nebraska, which are included in the category "Other" in Table 22, accounted for significant levels of employment in rawmaterials-sector activities in 1993. Employment in the "Other" category declined by 57 percent in 1993 from the level in 1992.
Employment data for the category of reclamation work in the raw-materials sector was collected for the first time in 1993 on the Form EIA-858. In 1993, the total amount of employment reported bt the industry as expended in reclamation projects was 491 person years. This was 23 percent higher than the combined person years expended in exploration, mining, milling, and processing in 1993.

Table 22. Employment In the U.S. Uranium Industry by State, 1993 (Person-Years)

\begin{tabular}{|c|c|c|}
\hline Etate & Totel & Pereent of Tosed \\
\hline 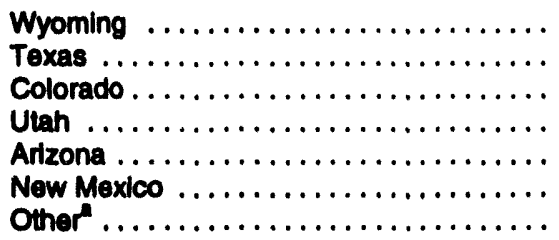 & $\begin{array}{r}118 \\
51 \\
65 \\
31 \\
14 \\
13 \\
88\end{array}$ & $\begin{array}{r}31.1 \\
13.4 \\
17.2 \\
8.0 \\
3.7 \\
3.4 \\
23.1\end{array}$ \\
\hline Total ${ }^{6}$ & 380 & 100.0 \\
\hline
\end{tabular}

Includes Florida, Louislana, Nebraska, Nevada, Washington.

'Does not include 491 person yoars in 1993 for employment in reclamation work relating to exploration, mining, miling, and processing. The collection of employment data for the reclamation category was initiated on the 1993 "Uranium Industry Annual Survey" (Form EIA-658).

Note: Totals may not equal sum of components because of independent rounding.

Source: Energy Information Adminlstration, Form ElA-858, "Uranlum Industry Annual Surver" (1893). 
Figure 10. Employment in the Uranlum Induatry by 8tate, 1989-1993

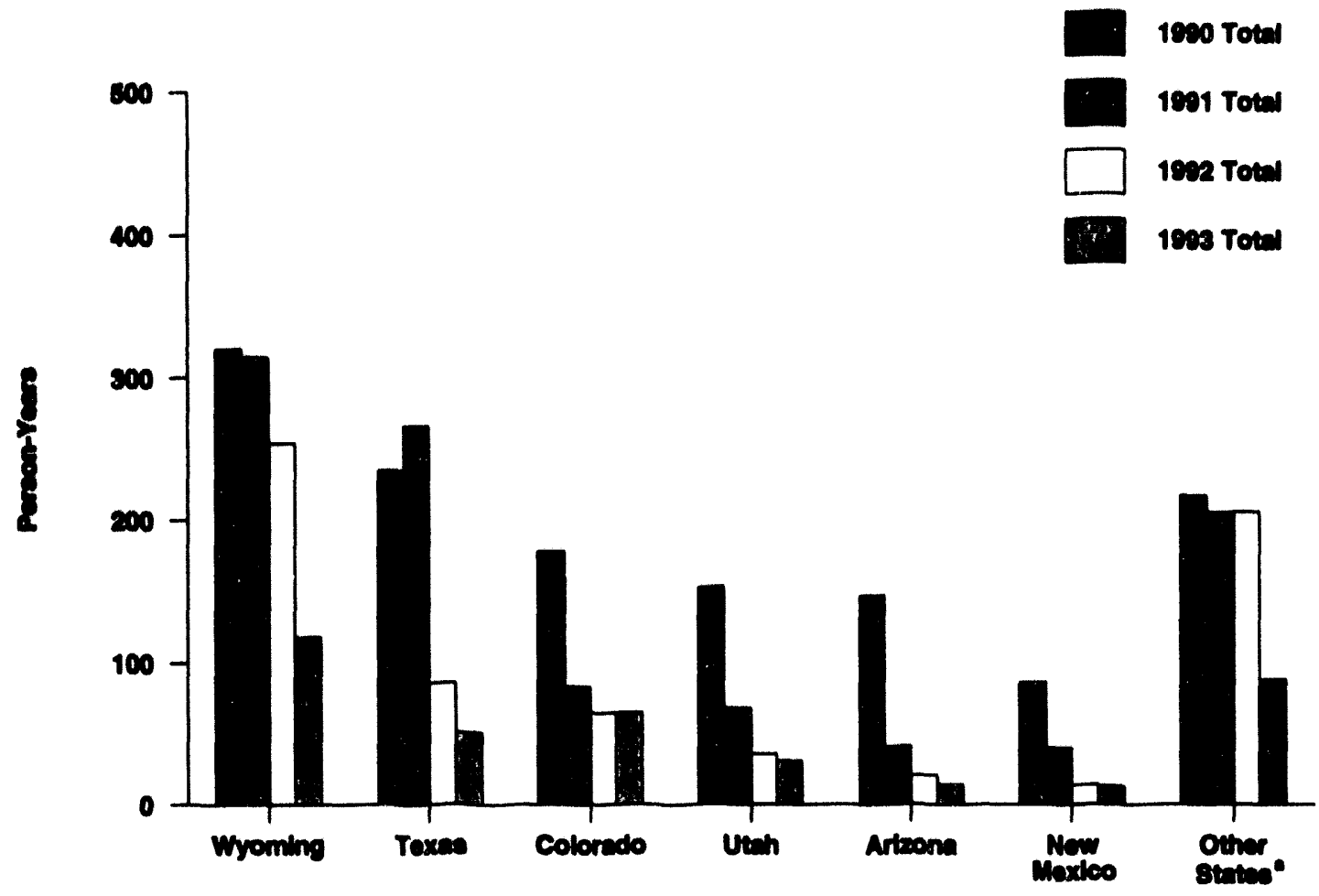

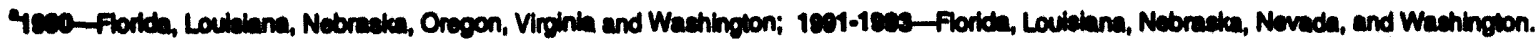

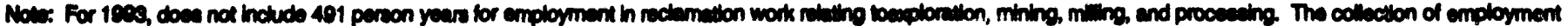

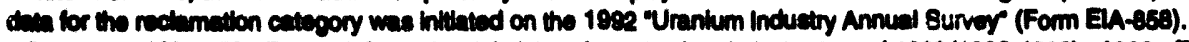

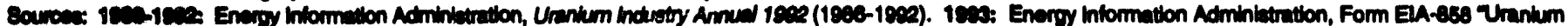
movity Amuel Burver (1900). 


\section{Uranlum Marketing Actlvities}

\section{Introduction}

This chapter contains information on uranium marketing activities, including the quantity of uranium delivered under purchase contracts in 1993 and expected to be delivered in 1994 and beyond, uranium prices, feed deliveries to domestic and foreign enrichment suppliers, uranium inventories, and secondary market transactions. Movement of both natural and enriched uranium materials in the primary and secondary markets illustrates for 1993 the normal market mechanisms used by U.S. utilities and suppliers to procure and dispose of uranium
(Figure 11). The uranium quantities throughout this chapter that are expressed as $\mathrm{U}_{3} \mathrm{O}_{8}$ equivalent (or $\mathrm{U}_{3} \mathrm{O}_{8} \mathrm{e}$ ) combine natural and enriched uranium. "Suppliers" are U.S. firms or foreign firms that exchange, loan, purchase, or sell uranium and are not U.S. electric utilities. This includes uranium brokers, converters, enrichers, fabricators, producers, and traders. Most of the uranium delivered to U.S. utilities in 1993 from suppliers involved deliveries of foreign-origin uranium. Some of these deliveries involved importation during 1993, and the remaining uranium was already in the United States and not imported in 1993.

\section{Figure 11. Uranlum Marketing Activity During 1993}

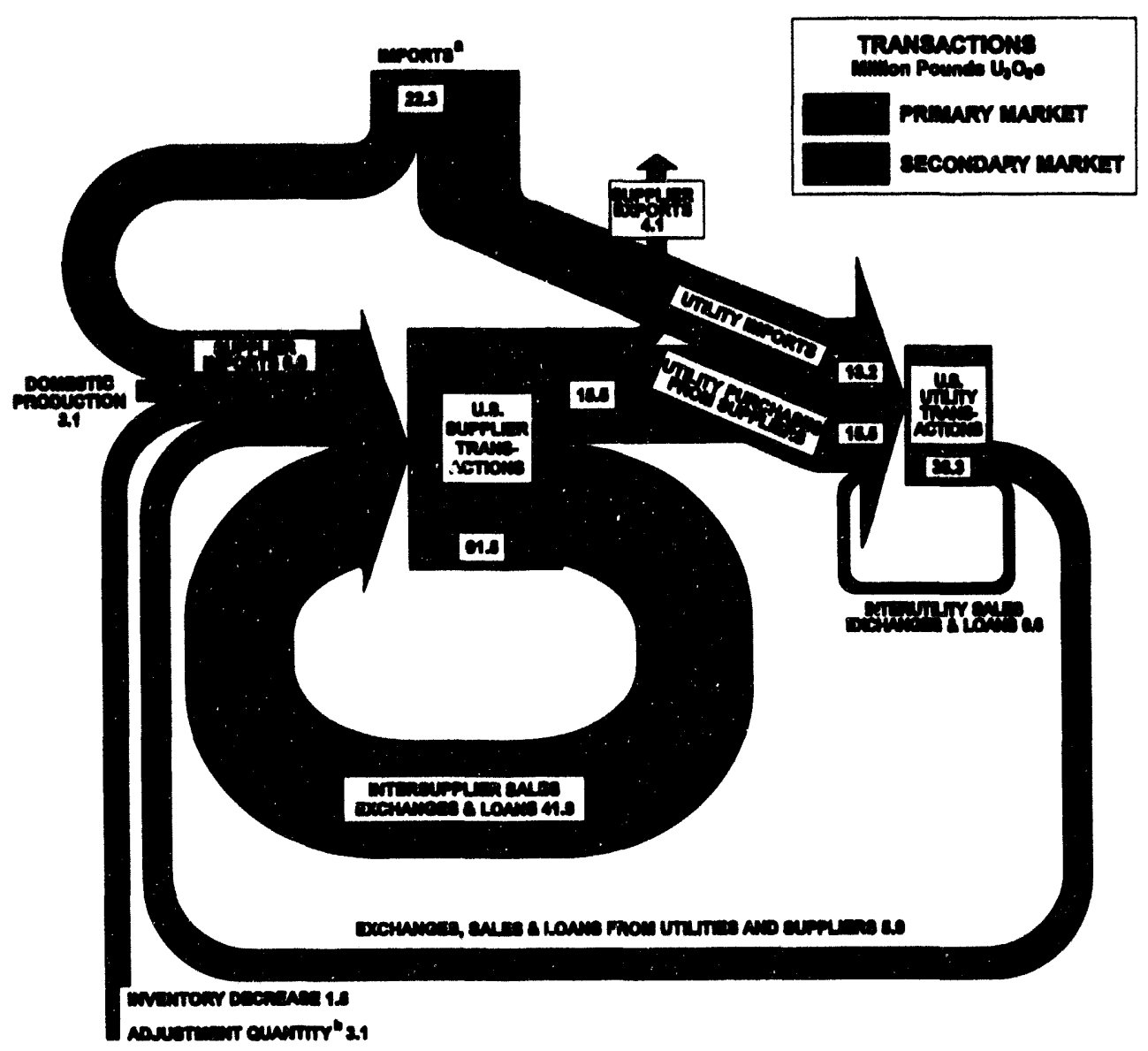

\footnotetext{
Thotudes imported uranium from purchaces and net inflows from axchanges and loan transactions.

The ecpuatment quanthy repreaents an amount of uranium needed to make the inputs and outputs equal.

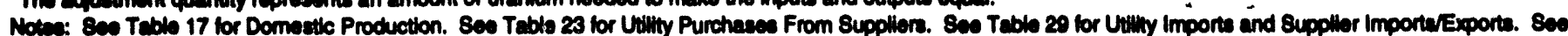

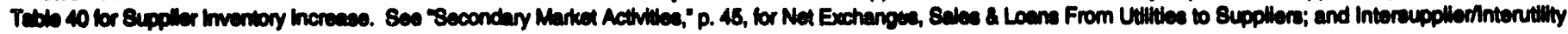
Bale, Exchenges \& Loans. $U_{2} \mathrm{O}_{2} 0=U_{3} \mathrm{O}_{1}$ equivelont.

8ources: Prepared by the Enorgy Information Adminietration, Office of Coal, Nuclear, Electric and Alemate Fuela, based on data reported on Form ElA-868 for 1983.
} 


\section{Domestic Purchase Commitments by Utilitles}

Deliveries of uranium from suppliers to U.S. utilities in 1993 totaled 15.5 million pounds $\mathrm{U}_{3} \mathrm{O}_{8} \mathrm{e}, 2.4$ million pounds less than the expected deliveries for contracts in place at the beginning of 1993 (Table 23). Projected cumulative deliveries reported for the forward 5-year period 1994 through 1998 decreased by 5.8 million pounds $\mathrm{U}_{3} \mathrm{O}_{8}$ e from year-end 1992 to year-end 1993, an 11-percent decline. This is attributable largely to the de- cline in the optional deliveries category, which decreased by 4.6 million pounds $\mathrm{U}_{3} \mathrm{O}_{2} \mathrm{e}$ ( 36 percent) for the 5-year period. Uranium delivery of firm and optional commitments to utilities for 1993 through 2000 and later are displayed in Figure 12.

Utilities signed 23 uranium purchase contracts with suppliers in 1993; 21 short-term contracts and 2 longterm contracts (Table 24). The total amount of uranium represented by these new contracts was 5.0 million pounds $\mathrm{U}_{3} \mathrm{O}_{8} \mathrm{e}$.

Table 23. Commitmente for Dellvery of Uranium from Suppliers to U.S. Utilities, 1993-2000 and Later (Million Pounds U. 0 , Equivalent)

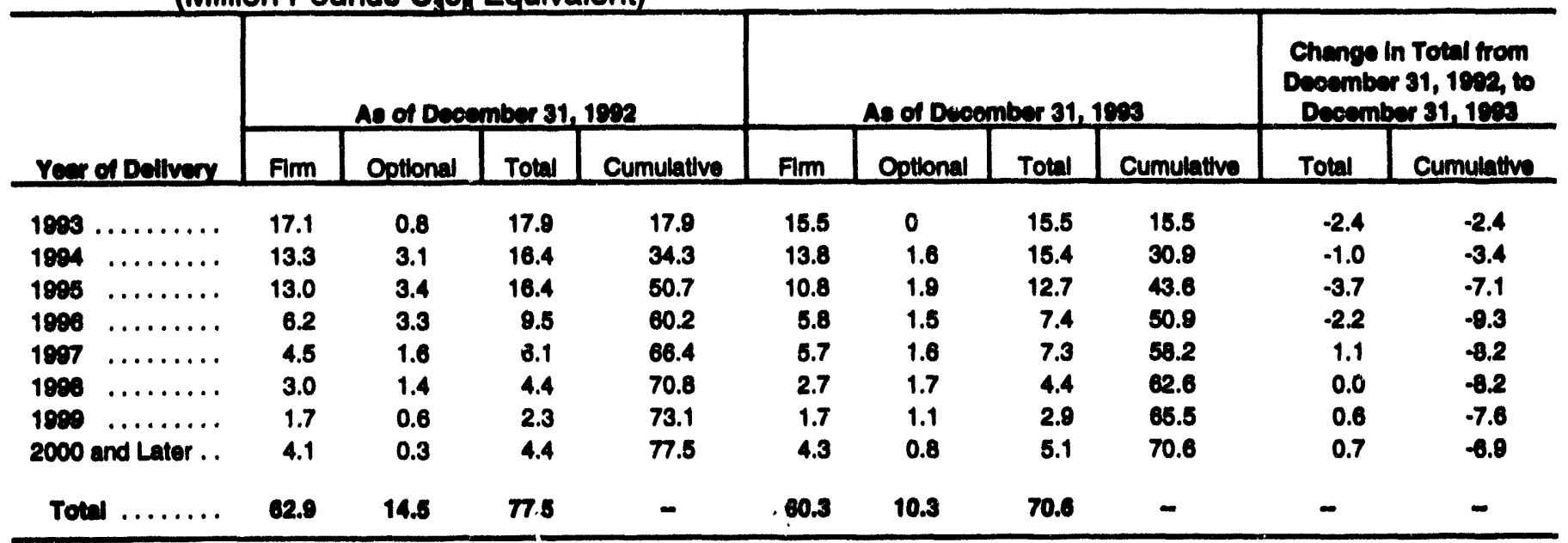

- a Not copilomblo.

Nowi Tein't miny not equal cum of components because of independent rounding.

Caurea: Ineroy Intormetion Administration, Form ElA-858, Uranlum Induatry Annual Surver" (1903).

Floure 12. Uranium Dellvery Commitments to U.S. Utilities from Suppliars, 1993-2000 and Later, as of Decomber 31, 1993

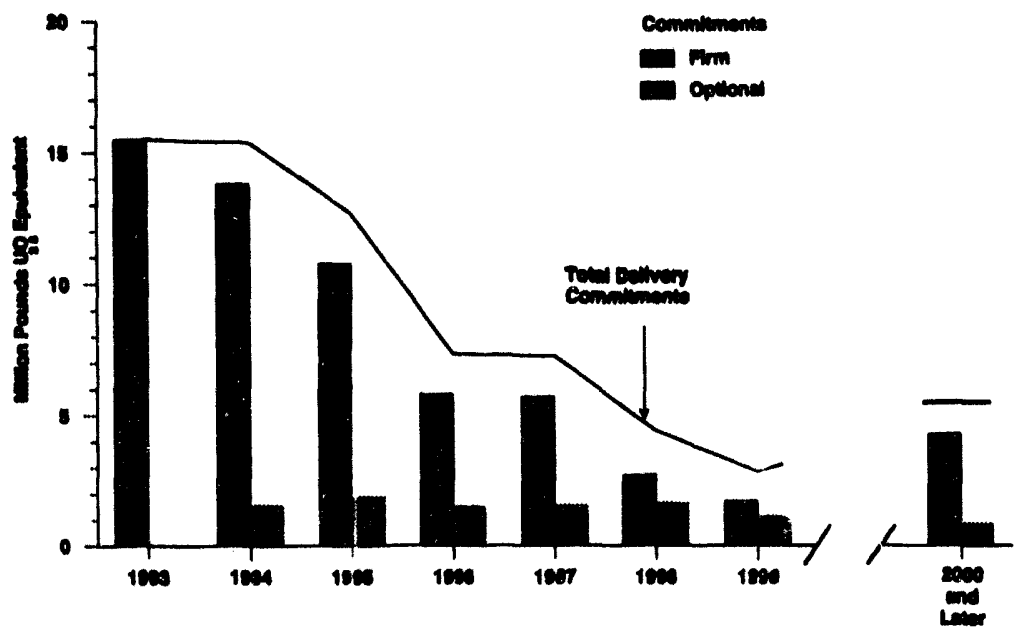

Now: The datu plotted for "2000 and Later" include more than 1 year.

Bouros: Energy Information Adminiatration, Form EIA-868 "Uranium Induatry Annuai Survor" (1983). 
Three categories of market-price-related contracts are: (1) contracts with a specific floor price, (2) contracts in which the floor price is related to production cost, and (3) contracts with no flcor price provision. For 1993 deliveries under market-price-related contracts, 1.2 million pounds $\mathrm{U}_{3} \mathrm{O}_{5}$ e (17 percent) had a price floor, 5.7 million pounds (79 percent) had no floor as associated with the market price; and 0.3 million pounds $\mathrm{U}_{3} \mathrm{O}_{4} e$ (4 percent) had a cost floor (Table 27). For all market-price contracts in place as of December 31, 1993, 27 percent of the total quantity to be delivered in all years had a price floor, 2 percent had a cost floor, and the remainder had no floor.

Table 26. Contract Arrangemonts Spectiled In Contract-Price Contracts for Dellvery of Uranlum from Suppllare to U.S. Utillee, $1092-2000$ and Leter, es of December 31, 1093

\begin{tabular}{|c|c|c|c|c|c|}
\hline \multirow[b]{2}{*}{ Yectol ochers? } & \multicolumn{2}{|c|}{ Find Puin } & \multicolumn{2}{|c|}{ 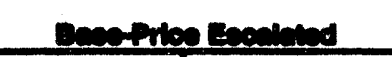 } & \multirow[b]{2}{*}{$\begin{array}{l}\text { Annual Toud } \\
\text { (million } \\
\text { pounds } \\
\text { U.0.0) }\end{array}$} \\
\hline & $\begin{array}{l}\text { Minon } \\
\text { Pound } \\
\text { Yoe. }\end{array}$ & $\begin{array}{l}\text { Percent of } \\
\text { Armud } \\
\text { Towal }\end{array}$ & $\begin{array}{l}\text { Mavion } \\
\text { Pound } \\
\text { U.0. }\end{array}$ & $\begin{array}{l}\text { Percemt of } \\
\text { Armual } \\
\text { Toled }\end{array}$ & \\
\hline $1803^{\circ}$ & 40 & $\infty 0.3$ & 3.4 & 40.7 & 8.3 \\
\hline $1804 \ldots$ & 32 & 62.8 & 2.0 & 47.2 & 6.1 \\
\hline $1006 \ldots \ldots \ldots \ldots$ & 44 & 60.1 & 2.1 & 31.0 & 6.5 \\
\hline $1800 \ldots \ldots \ldots$ & 0.8 & 18.8 & 2.3 & 81.2 & 2.8 \\
\hline $1897 \quad \ldots \ldots \ldots \ldots \ldots \ldots \ldots \ldots \ldots$ & 0.3 & 8.7 & 32 & 81.3 & 3.5 \\
\hline $1808 \quad \ldots \ldots \ldots \ldots \ldots \ldots \ldots \ldots \ldots$ & 0.1 & 6.6 & 1.6 & 83.4 & 1.8 \\
\hline $1000 \quad \ldots \ldots \ldots \ldots \ldots \ldots \ldots \ldots \ldots \ldots$ & 0.1 & 20.3 & 0.3 & 74.7 & 0.4 \\
\hline 2000 and Later $\ldots \ldots \ldots \ldots \ldots \ldots$ & 0.1 & 8.5 & 1.1 & 81.5 & 12 \\
\hline 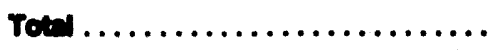 & 127 & 8s.1 & 16.7 & 840 & 30.4 \\
\hline
\end{tabular}

Actual dellivedion.

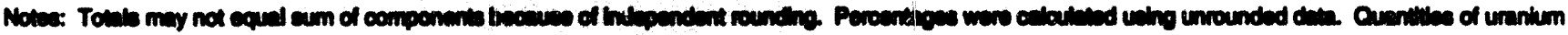

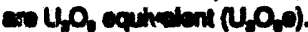

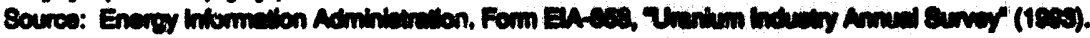

Table 27. Floor Price Arrangements Epecillad in Martet-Piles Contrects for Dellvery of Uranlum from

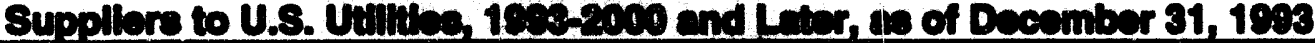

\begin{tabular}{|c|c|c|c|c|c|c|c|}
\hline \multirow[b]{2}{*}{ Yecr of octivest } & \multicolumn{2}{|c|}{ 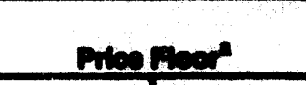 } & \multicolumn{2}{|c|}{$\operatorname{coshost}$} & \multicolumn{2}{|c|}{ Noper } & \multirow[b]{2}{*}{ 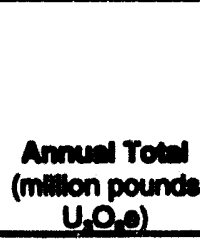 } \\
\hline & $\begin{array}{l}\text { Mmion } \\
\text { Pound } \\
\text { uea }\end{array}$ & 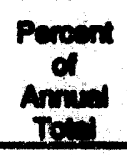 & $\begin{array}{l}\text { Mmon } \\
\text { Pound } \\
\text { Uoe }\end{array}$ & $\begin{array}{l}\text { Percent } \\
\text { of } \\
\text { Anvivel } \\
\text { Toted }\end{array}$ & $\begin{array}{c}\text { Muman } \\
\text { Pound } \\
\text { uoe }\end{array}$ & $\begin{array}{l}\text { Porcent of } \\
\text { Ansud Tot }\end{array}$ & \\
\hline 1803 & 12 & 16.5 & 0.3 & 4.2 & 6.7 & 79.3 & 7.2 \\
\hline $1804 \ldots \ldots \ldots \ldots \ldots \ldots$ & 1.1 & 122 & 0.3 & 3.2 & 7.9 & 84.6 & 9.3 \\
\hline$i 295 \ldots \ldots \ldots \ldots \ldots \ldots . . . . . . .6$ & 1.8 & 20.4 & 0 & 0 & 4.4 & 71.6 & 6.2 \\
\hline $1896 \ldots \ldots \ldots \ldots$ & 1.7 & 30.8 & 0 & 0 & 2.8 & 61.2 & 4.5 \\
\hline 1997 & 1.2 & 30.8 & 0 & 0 & 2.6 & 69.2 & 3.8 \\
\hline 1898 & 1.1 & 38.4 & 0 & 0 & 1.7 & 61.6 & 2.8 \\
\hline $1990 \ldots \ldots \ldots \ldots$ & 0.0 & 36.0 & 0 & 0 & 1.6 & 65.0 & 2.4 \\
\hline 2000 and Leter ........... & 1.8 & 48.8 & 0 & 0 & 2.0 & 51.2 & 3.9 \\
\hline Totel. & 100 & 270 & 00 & 1.5 & 20.7 & 71.6 & 60.1 \\
\hline
\end{tabular}

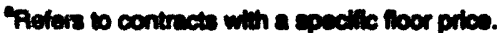

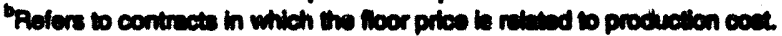

PRefers to contrincte with no flocer pitce provition.

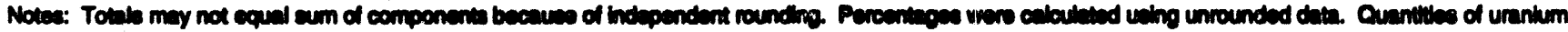

aro $U_{3}, O_{1}$ equivalent $(U, 0,0)$.

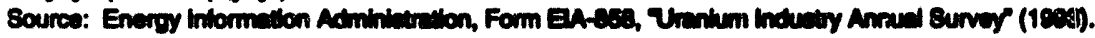




\section{Prices of Domestic Purchases by Utilities}

The first section of Table 28 is the weighted average of reported prices for deliveries under purchases with contract-specified prices. The average price for this type of delivery in 1993 was $\$ 14.96$ per pound $\mathrm{U}_{3} \mathrm{O}_{8}$, up 14 percent from the average of $\$ 13.16$ reported for 1992.

The second section is the weighted ayerage of reported prices for deliveries under market-price-related contracts. The average price for this type of delivery declined 21 percent from $\$ 13.89$ in 1992 to $\$ 11.03$ in 1993. Prices for market-price-related contracts with a floor price declined 19 percent from $\$ 18.35$ in 1992 to $\$ 14.87$ in 1993, while the aggregate average for all other market-price-related contracts rose 11 percent from $\$ 8.65$ in 1992 to $\$ 9.57$ in 1993.

The final section is deliveries and prices for contractspecified price and market-price-related procurements combined. This provides a comprehensive average price for all deliveries made by suppliers to U.S. utilities, except those made under litigation settlements and "other" pricing mechanisms. The reported prices for 1993 averaged $\$ 13.14$ per pound $\mathrm{U}_{3} \mathrm{O}_{8}$ equivalent, a 2-percent decrease compared with the 1992 average of reported prices of $\$ 13.45$ per pound (Table 28 ).

Table 28. Average of Prices Pald for Purchases by U.S. Utilities from Suppliers, 1982-1993

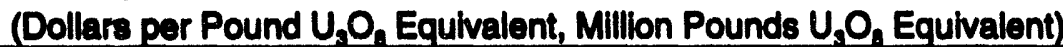

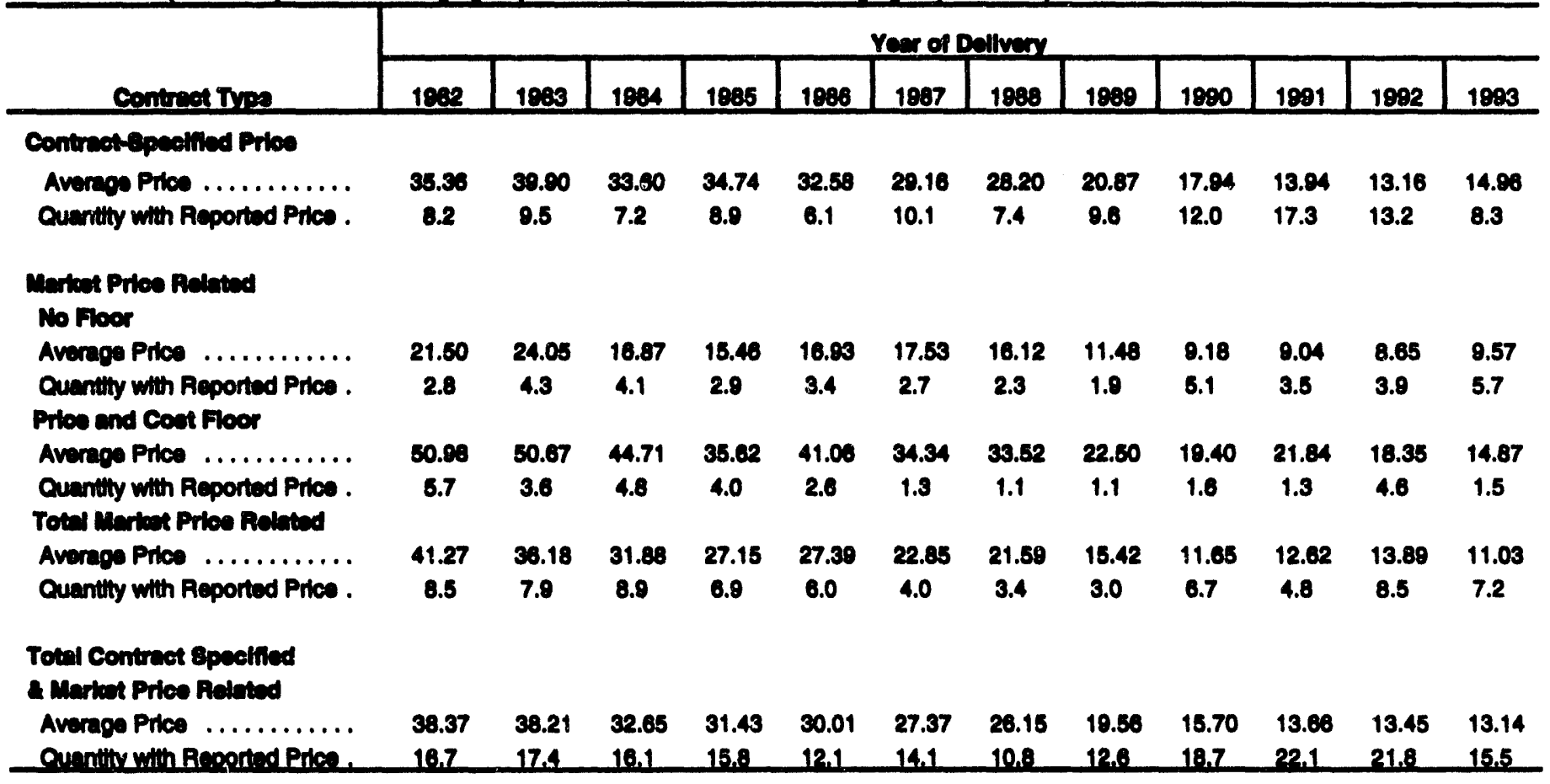

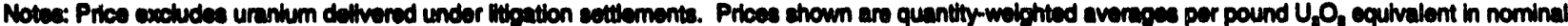
U.8. dollan.

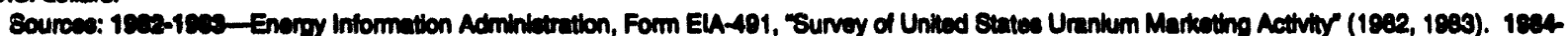

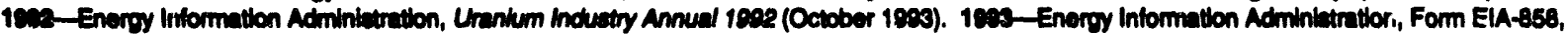
Urenium induatry Annual Eurvor (180s). 


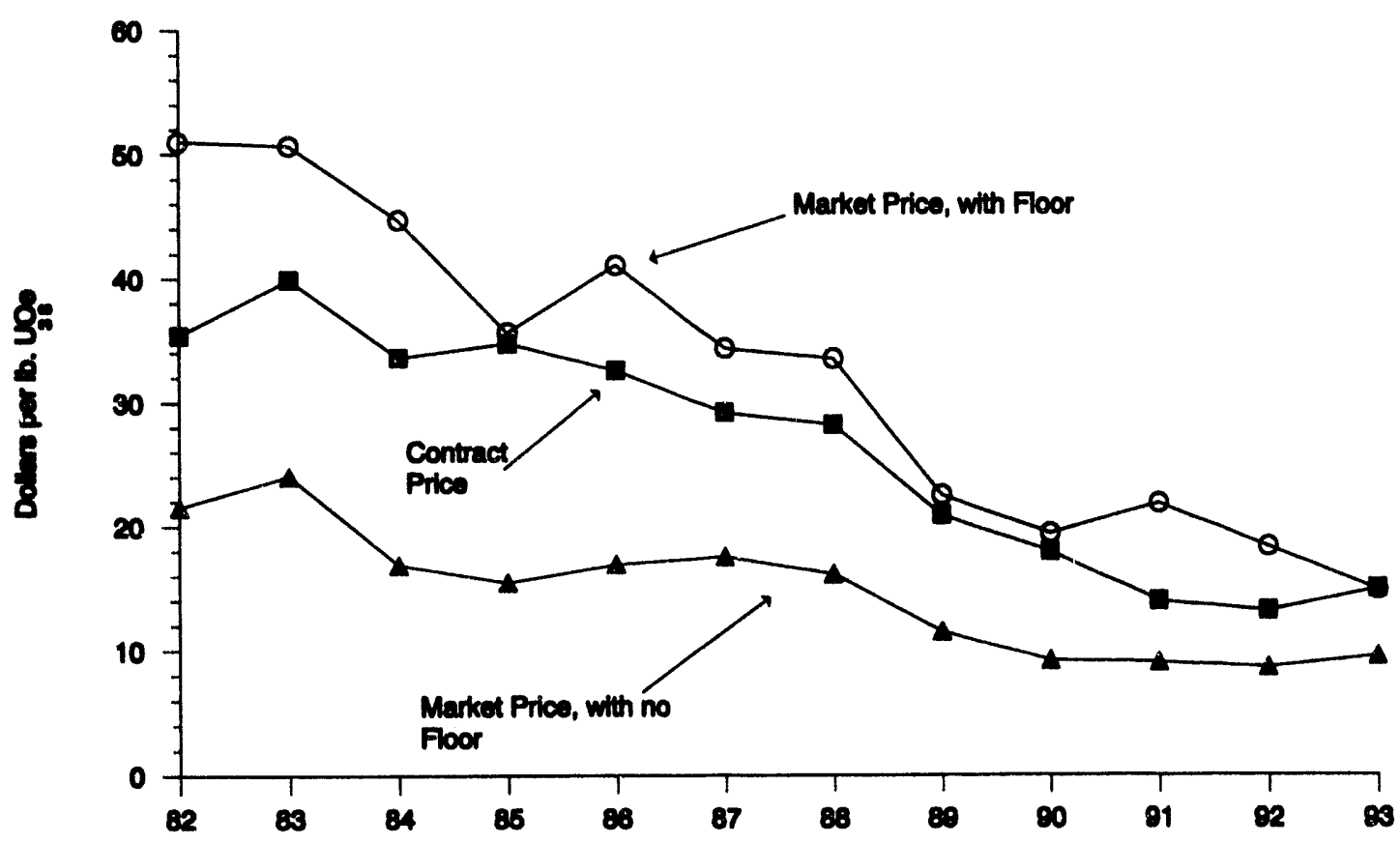

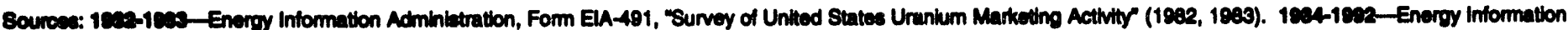

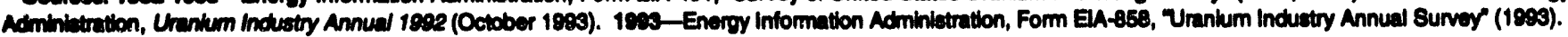

\section{Uranium Imports and Exports}

Imports include utility, supplier, and trader/broker purchases reported as imports of foreign-origin uranium materials into the United States. Uranium materials reported as imports under loan and exchange transactions, custody/storage arrangements, and the delivery of foreign material for enrichment that is subsequently exported are also included in the "Other" category. U.S. utilities and suppliers imported 21.0 million pounds of uranium under purchase contracts in 1993,10 percent less than the 23.3 million pounds of like imports in 1992 (Table 29). Almost all of this imported material came from Australia, Canada, China, Gabon, Germany, Kazakhstan, Kyrgyzstan, Mongolia, Namibia, Russia, United Kingdom, and Uzbekistan in 1993. From 1967 through 1993, U.S. companies imported a cumulative total of 220.3 million pounds $\mathrm{U}_{3} \mathrm{O}_{8} \mathrm{e}$ under purchase contracts. As of December 31,1993 , import-purchase contracts were in place for an aditional 111.3 million pounds from 1994 through 2000 and later.

\begin{tabular}{cc}
$\begin{array}{c}\text { Top Five } \\
\text { Origin Countries }\end{array}$ & $\begin{array}{c}\mathrm{U}_{3} \mathrm{O}_{3} \Theta \\
\text { (million pounds) }\end{array}$ \\
\hline Canada & 10.8 \\
China & 3.2 \\
Australia & 1.5 \\
Russia & 1.4 \\
Namibia & 0.7
\end{tabular}

Export sales of uranium by suppliers in 1993 totaled 3.0 million pounds, up from the 2.8 million pounds reported for 1992. Since 1967, U.S. companies have exported a cumulative total of 78.7 million pounds $\mathrm{U}_{3} \mathrm{O}_{8}$ equivalent under sales contracts. As of December 31, 1993, exportsales contracts were in place for an additional 19.4 million pounds from 1994 through 2000 and later. 
Table 29. Dellverles and Commitments of Uranlum Imports and Exports by Transaction Type, 1967 to 2000 and Later (Million Pounds $\mathrm{U}_{3} \mathrm{O}_{8}$ Equivalent)

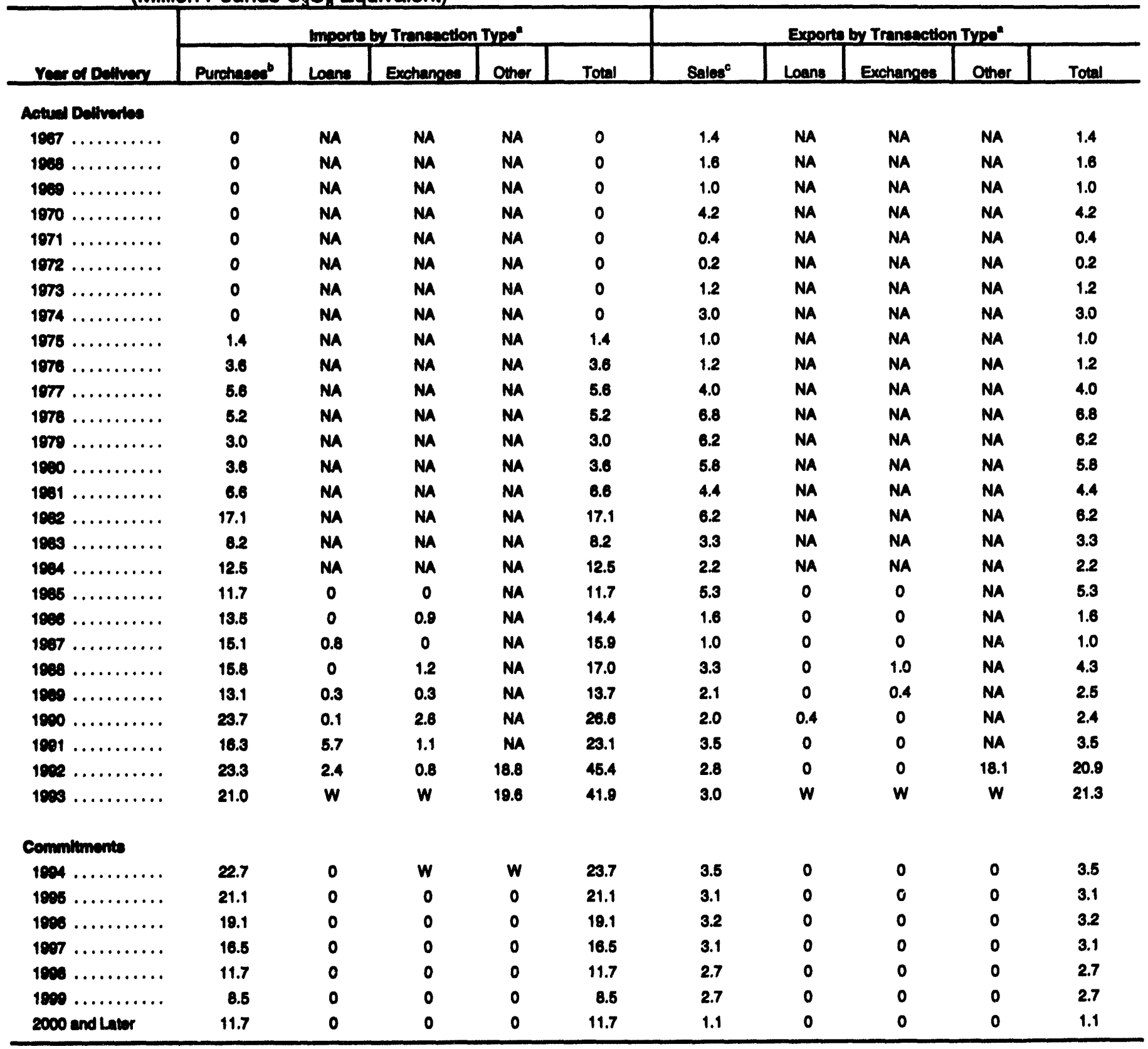

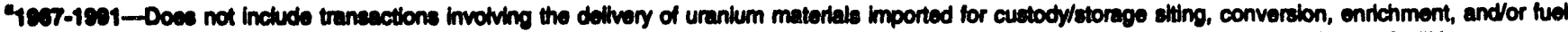

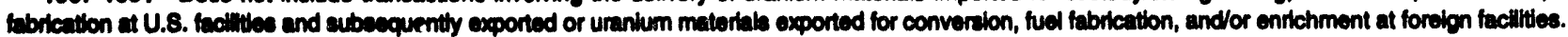

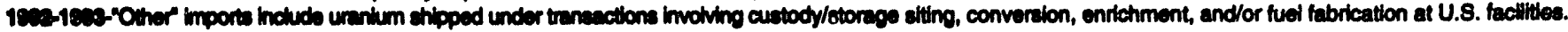
Other exports inctude unanium chipped from converion, enrichment, and/or fuel fabrication factilties in the United States.

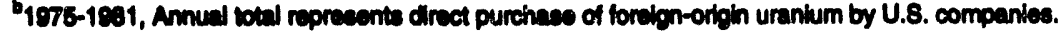

1907-1831, Annual botel represents exports by U.8. unanium producure only.

$W=$ Witheld to avoid dicoloeure of individual company data.

Ma = Not avallable.

Note: Totale may not equal sum of componente becaues of independent rounding.

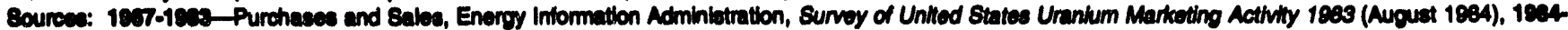

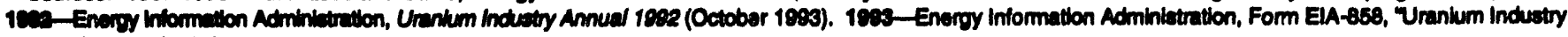
Annuel Sunver (1800). 
igure 15. Actual and Committed Imports and Exports of Uranlum for Commerclal Uses, 1967-2000 and Later
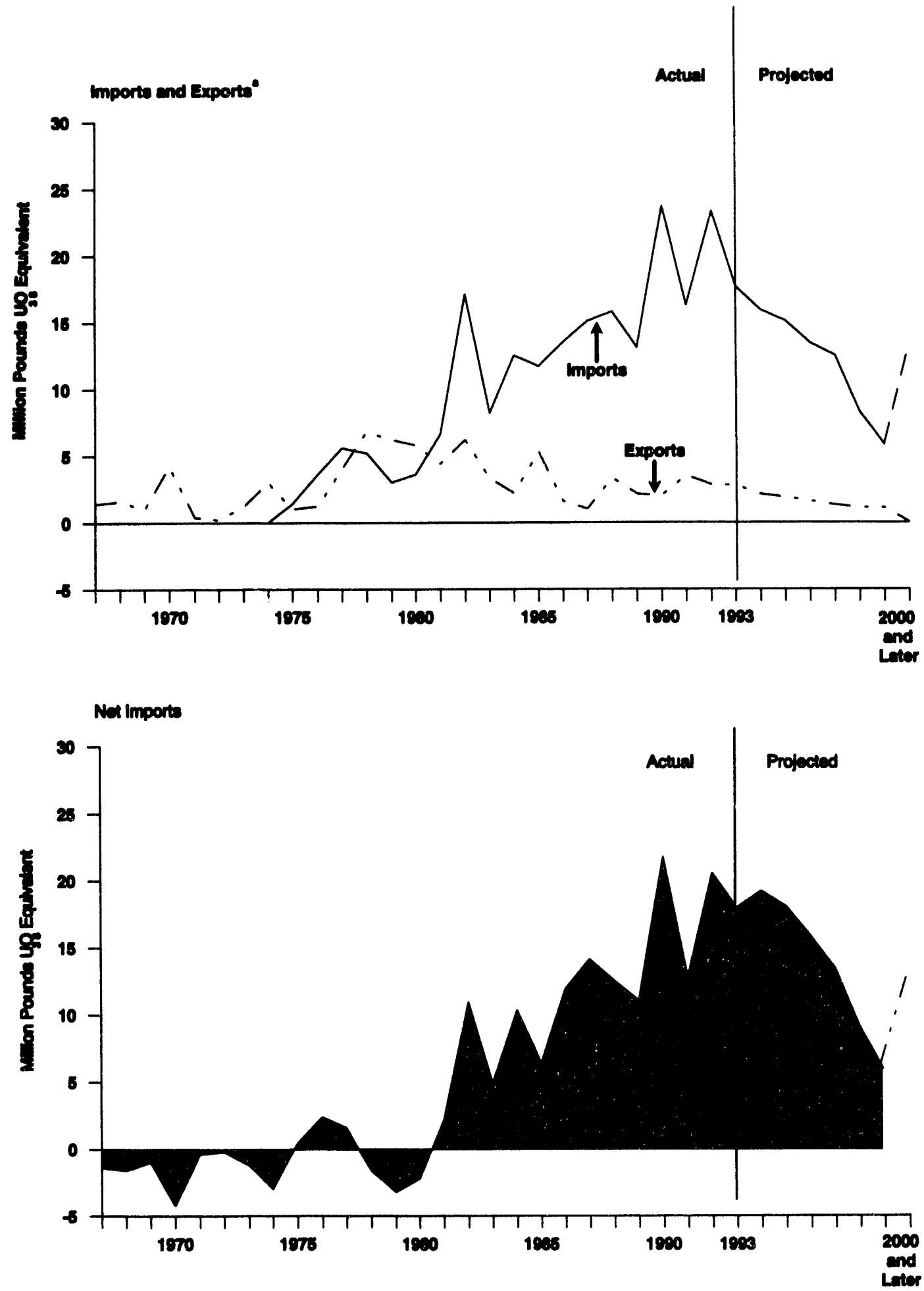

- Annual boteds for imports are for purchase contracts only and for exports are for eales contrects only.

Nota: Datu plotted for years 1907 through 1993 are for ectud deltwerles; data plotted for 1894 and later are commitments. The data point plotted for "2000 and Later includes

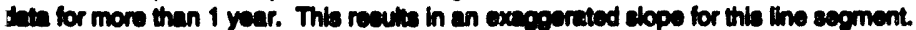

Eources: 1697-16es-Punchases and Ealos, Energy Information Adminietration, Survoy of Unhed States Uranium Marketing Activity 1983 (August 1884), 1894-1802-Energy

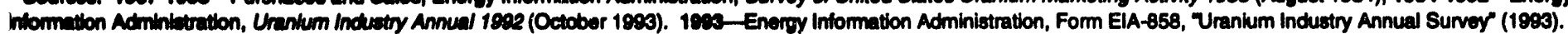


U.S. utilities accounted for roughly 75 percent of the 1993 purchase-contract imports. For years beyond 1993, utility commitments represent 90 percent of the total quantity under import-purchase contracts from suppliers (Table 30). Of the 1993 uranium import deliveries under contract-specified-price contracts, 65 percent had a fixed price and the remaining 35 percent had base price with escalation (Table 31). By comparison, contract-price contracts accounted for 59 percent of the uranium delivered to U.S. utilities by suppliers, and 41 percent were fixed-price (Table 26). Eighty-one percent of the uranium imported by U.S. utilities in 1993 was delivered under market-price-related contracts, and 39 percent of these contracts included a cost or price floor (Table 32). By comparison, of the uranium delivered to U.S. utilities by suppliers, market-price-related contracts accounted for $\mathbf{4 6}$ percent of the total and 21 percent of the contracts included a cost or price floor (Table 27).

For years beyond 1993, most of the uranium for which U.S. utilities have current import commitments will be delivered under market-price-related contracts, and roughly one-half of the total committed quantity under this type of contract is attributable to contracts which specify a floor price.

Similar data on contracts for imports by suppliers are not presented because the number of contracts is insufficient to avoid disclosure of individual company data.

Table 30. Commitments for Delivery of Uranium Imports to U.S. Utilities and Suppliers Under Purchase-Contract Imports, $1993-2000$ and Later, as of December 31, 1993 (Million Pounds $\mathrm{U}_{3} \mathrm{O}_{8}$ Equivalent)

\begin{tabular}{|c|c|c|c|c|c|c|c|c|c|c|c|c|}
\hline \multirow{2}{*}{$\begin{array}{c}\text { Year of Dellh- } \\
\text { ens }\end{array}$} & \multicolumn{4}{|c|}{ Imports by velutese } & \multicolumn{4}{|c|}{ Insorte by supplene" } & \multicolumn{4}{|c|}{ Comblned lnoexte } \\
\hline & Firm & Optional & Total & Cumulative & Firm & Optional & Total & Cumulatti- & Firm & Optional & Total & Curnulative \\
\hline $1993 \ldots \ldots \ldots$ & 15.7 & 0 & 15.7 & 15.7 & 5.3 & 0 & 5.3 & 5.3 & 21.0 & 0 & 21.0 & 21.0 \\
\hline $1984 \ldots$ & 16.3 & 2.8 & 19.1 & 34.8 & 3.5 & 0 & 3.5 & 8.8 & 19.9 & 2.8 & 22.7 & 49.7 \\
\hline 1995 & 14.1 & 5.3 & 19.4 & 54.2 & 1.7 & 0 & 1.7 & 10.6 & 15.8 & 5.3 & 21.1 & 64.8 \\
\hline 1898 & 11.0 & 6.3 & 17.3 & 71.5 & 1.8 & 0 & 1.8 & 12.4 & 12.8 & 6.3 & 19.1 & 83.8 \\
\hline 1897 & 8.9 & 4.8 & 14.7 & 86.2 & 1.7 & 0 & 1.7 & 14.1 & 11.6 & 4.8 & 16.5 & 100.3 \\
\hline $1998 \ldots \ldots \ldots$ & 6.3 & 4.2 & 10.5 & 96.7 & 1.0 & 0.2 & 1.2 & 15.3 & 7.3 & 4.4 & 11.7 & 112.1 \\
\hline 1999 & 4.7 & 2.7 & 7.4 & 104.1 & 1.0 & 0.1 & 1.1 & 16.5 & 5.7 & 2.8 & 8.5 & 120.6 \\
\hline 2000 and Later & 6.4 & 5.3 & 11.7 & 115.8 & 0 & 0.1 & 0.1 & 16.5 & 6.4 & 5.3 & 11.7 & 132.3 \\
\hline Total ......... & 84.4 & 31.4 & 115.8 & - & 16.1 & 0.4 & 16.5 & - & 100.5 & 31.8 & 132.3 & - \\
\hline
\end{tabular}

"For 1893, Includes U.S. utllity, supplier, and trader/broker purchases reported as imports of foreign-origin uranium materials into the United States. Uranium materials reported as imports under loan and exchange transactions are excluded. For "1833-2000 and Later," the figure shown equals the amount of import commitrnents in each year under purchase contracts by utillites, suppliers, and tradere/brokers.

- = Not applicable.

Note: Totals may not equal sum of components because of independent rounding.

Source: Energy Information Administration, Form ElA-858, "Uranium Industry Annual Survey" (1893). 
Table 31. Contract Arrangements Speclfied in Contract-Price Contracts for Delivery of Uranium Imports to U.S. Utillities, 1993-2000 and Later, as of December 31, 1993

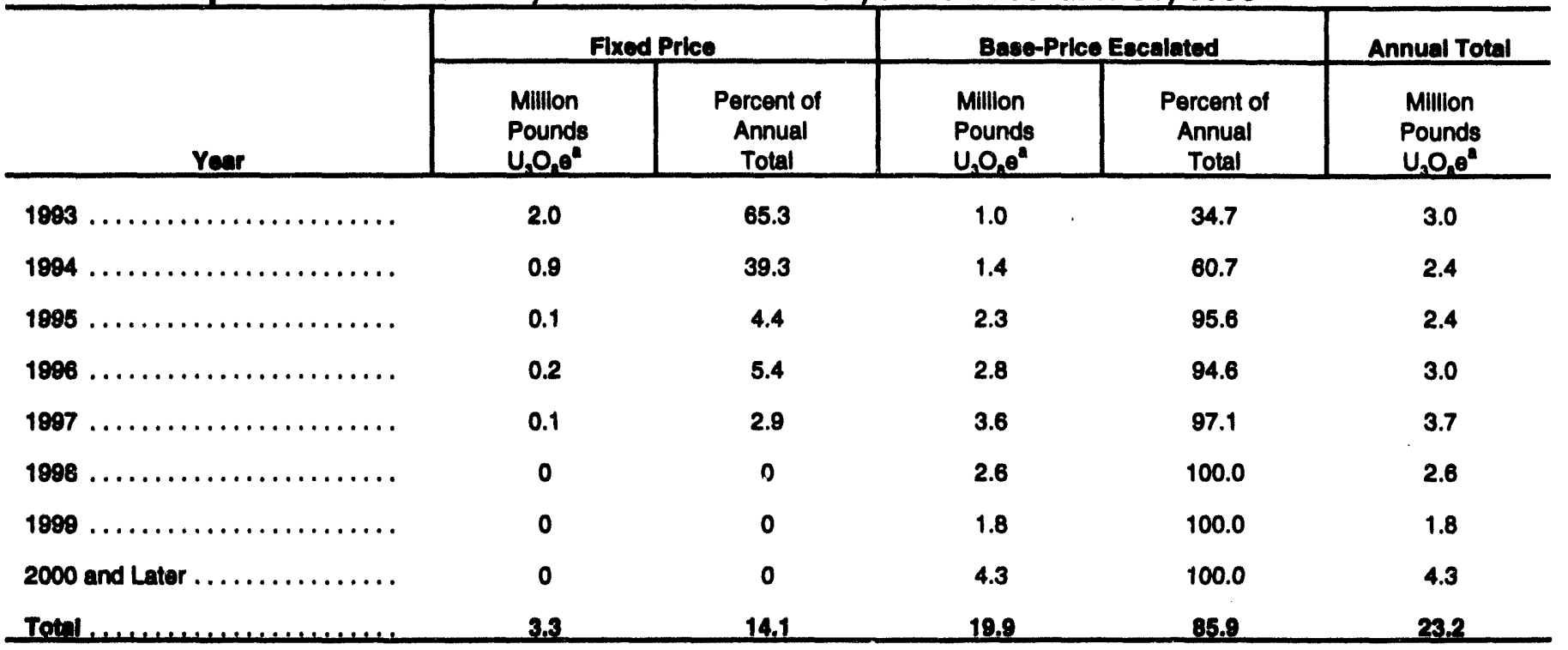

"For 1893, includes U.8. utility, suppller, and tradorforoker purchases reported as imports of forelgn-origin uranium materials, U,O, equivalont, into the United States. Uranlum materials reported as imports under loan and exchange transactions are excluded. For "1994-2000 and Later", the figure shown equals the amount of import commitments in each year under purchase contracts by uttllities, suppliers, and tradorabrokers.

Note: Totals may not equal sum of components because of independent rounding.

Source: Energy information Administration, Form ElA-658, "Uranium Industry Annual Survey" (1893).

Table 32. Floor Price Arrangements Specifled In Market-Price Contracts for Dellvery of Uranlum Imports to U.S. Utilities, 1993-2000 and Later, as of December 31, 1993

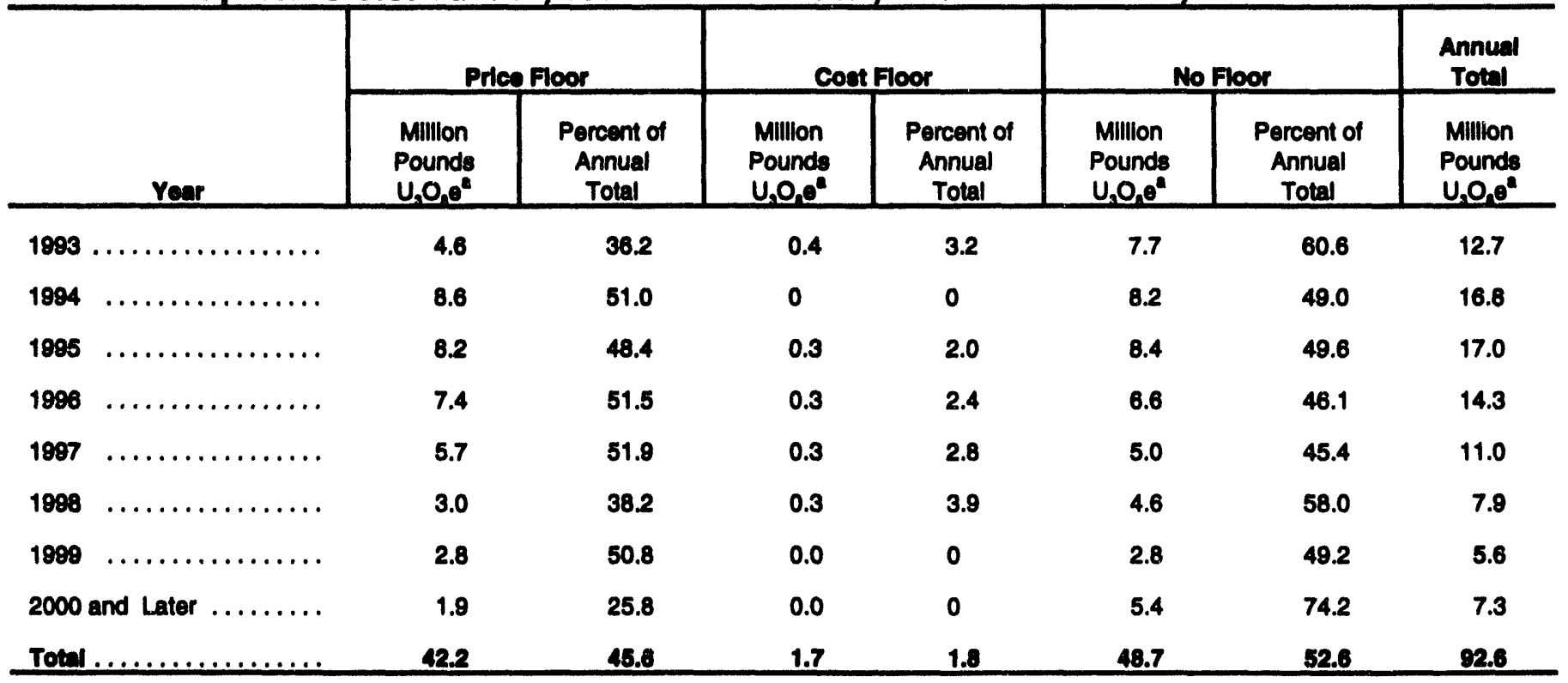

For 1893, includes U.8. Uthy, euppler, and traderforoker purchases reported as imports of forelon-origin uranium materials, U,O, equivalent, into the United States. Uranium matertals reported as imports under ban and exchange traneactions are excluded. For "1984-2000 and Later", the figure shown equals the amount of import commitments in each year under purchase contrects by utillites, suppliers, and tradore/orokers.

Note: Totals may not equal sum of components because of independent rounding.

8ource: Energy Information Administration, Form EIA-858, Uranium Industry Annual Survey" (1993). 
Since 1970, 261 import contracts have been signed for purchase of 341.2 million pounds $\mathrm{U}_{3} \mathrm{O}_{8} \mathrm{e}$ (Table 33 ). Because of litigation, cancellations, and contract morifications, however, many of the originally scheduled commitments were not delivered to U.S. customers. The actual deliveries for 1970 through 1993 have amounted to 220.3 million pounds.

\section{New Import Commitments}

Suppliers and utilities signed 25 new purchase contracts in 1993 for imports totaling 16.0 million pounds of uranium. Short-term transactions signed by U.S. utilities (for delivery from 1993 through 1994) totaled 0.8 million pounds of uranium. New long-term import-purchase contracts by utilities totaled 10.2 million pounds $\mathrm{U}_{3} \mathrm{O}_{8} \mathrm{e}$ (for delivery scheduled after 1994).

Table 33. Historical Commitments and Actual Dollveries of Forelgn-Origin Uranium, 1970-1993

\begin{tabular}{|c|c|c|c|}
\hline \multirow[b]{2}{*}{ Year of Contreot Binniner } & \multicolumn{2}{|c|}{ Now Contrects end Commituments } & \multirow{2}{*}{$\begin{array}{l}\text { Actual Delliveries" } \\
\text { (million pounds U,O,O) }\end{array}$} \\
\hline & Number & Million Pounds U,O. & \\
\hline $1970-1880$ & 18 & 63.4 & 22.4 \\
\hline $1981 \ldots \ldots \ldots$ & 4 & 9.8 & 6.6 \\
\hline (n..., & 17 & 28.4 & 17.1 \\
\hline 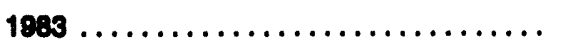 & 8 & 6.2 & 8.2 \\
\hline $1984 \ldots \ldots \ldots \ldots \ldots \ldots \ldots \ldots \ldots$ & 15 & 11.1 & 12.5 \\
\hline $1985 \ldots \ldots \ldots \ldots \ldots \ldots \ldots \ldots \ldots \ldots$ & 10 & 14.9 & 11.7 \\
\hline $1986 \ldots \ldots \ldots \ldots \ldots \ldots \ldots \ldots \ldots \ldots$ & 15 & 22.1 & 13.5 \\
\hline $1987 \ldots \ldots \ldots \ldots \ldots \ldots \ldots \ldots \ldots \ldots$ & 30 & 26.6 & 15.1 \\
\hline $1988 \ldots$ & 23 & 28.6 & 15.8 \\
\hline $1989 \ldots \ldots \ldots \ldots \ldots \ldots \ldots \ldots \ldots \ldots$ & 19 & 19.7 & 13.1 \\
\hline $1990 \ldots \ldots \ldots \ldots \ldots \ldots \ldots \ldots \ldots$ & 22 & 38.9 & 23.7 \\
\hline $1991 \ldots \ldots \ldots \ldots \ldots \ldots \ldots \ldots \ldots \ldots$, & 18 & 26.0 & 16.3 \\
\hline $1992, \ldots \ldots \ldots \ldots \ldots \ldots$ & 37 & 29.5 & 23.3 \\
\hline $1983 \ldots \ldots \ldots \ldots \ldots \ldots \ldots \ldots \ldots \ldots$ & 25 & 16.0 & 21.0 \\
\hline (n............. & 261 & 341.2 & 220.3 \\
\hline
\end{tabular}

Total new contrectual commitmente, $U_{3}, O_{1}$ equivalent, as of the year shown for dellvery in the year of contract signing and/or tuture yoars.

For 1985-1993, the figure shown inctudes U.8. utuly, eupplier, and traderftroker purchases reported as imports of uranium materials, U,O, equivalent, into the United States. Uranlum materials reported es imports under loan and exchange transactions are excluded. Actual deliveries began in 1975.

Sources: 1970-1603-Energy Informettion Adminictration, Survoy of United States Uranium Marketing Activity 1983 (Auguet 1963). 1994-1602-Energy Information Administration, Urantum Induetry Annual 1992 (October 1993). 1909-Energy Information Adminietration, Form EIA-858, Uranium Industry Annual Survor" (1993).

\section{Prices of Uranium Imports}

The quantity-weighted averages of prices paid by all suppliers and U.S. utilities for deliveries of uranium under purchase contract imports in 1993 was $\$ 10.53$ per pound $\mathrm{U}_{3} \mathrm{O}_{8}$ e, down 7 percent from the $\$ 11.34$ for deliveries in
1992 (Table 34). New short-term (deliveries in 1993 through 1994) import-purchase contracts signed by U.S. utilities in 1993 totaled 0.8 million pounds, and the quantity-weighted average of the prices paid under these contracts was $\$ 8.44$ per pound $\mathrm{U}_{3} \mathrm{O}_{8} e$. 
Table 34. Average of Prices Pald for Imported Uranlum Dellvered to U.S. Utilities and 8uppllers, 1983-1993

(Dollars per Pound $\mathrm{U}, \mathrm{O}$, Equivalent, Million Pounds $\mathrm{U}, \mathrm{O}$, Equivalent)

\begin{tabular}{|c|c|c|c|c|c|c|c|c|c|c|c|}
\hline mem & 1003 & 1094 & 1806 & 1900 & 1897 & 1900 & 1000 & 1000 & 1001 & 1902 & 1003 \\
\hline Average Price & 26.16 & 21.86 & 20.08 & 20.07 & 19.14 & 19.03 & 16.75 & 12.55 & 15.55 & 11.34 & 10.53 \\
\hline Quantity with Reported Price ... & 8.2 & 11.1 & 10.7 & 12.8 & 12.9 & 15.2 & 13.1 & 23.5 & 15.9 & 22.4 & 21.0 \\
\hline Total Quanttly Dellwered" & 8.2 & 12.5 & 11.7 & 13.5 & 15.1 & 15.8 & 13.1 & 23.7 & 16.3 & 23.3 & 21.0 \\
\hline Percentage of Imports Dellvered & & & & & & & & & & & \\
\hline h Ropor & 100 & 89 & 91 & 95 & 85 & 96 & 100 & 99 & 98 & 96 & 100 \\
\hline
\end{tabular}

The figure shown includes U.S. Utilly, supplier, and traderforoker purchases reported as imports of uranium matertals into the United 8tates. Umanium mutertals reported es imports under loan and exchango transections are excluded.

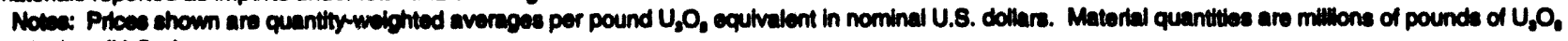
cquivalont $(\mathrm{U}, 0,0)$

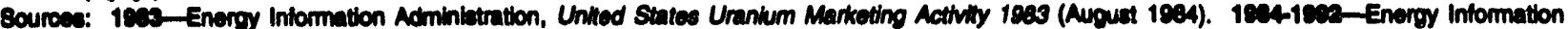

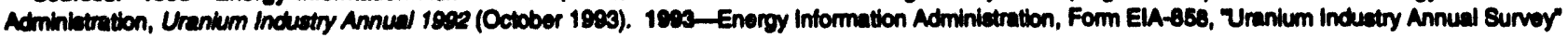
(1903).

Fgure 16. U.S. Uranium Imports and Prices, 1983-1993

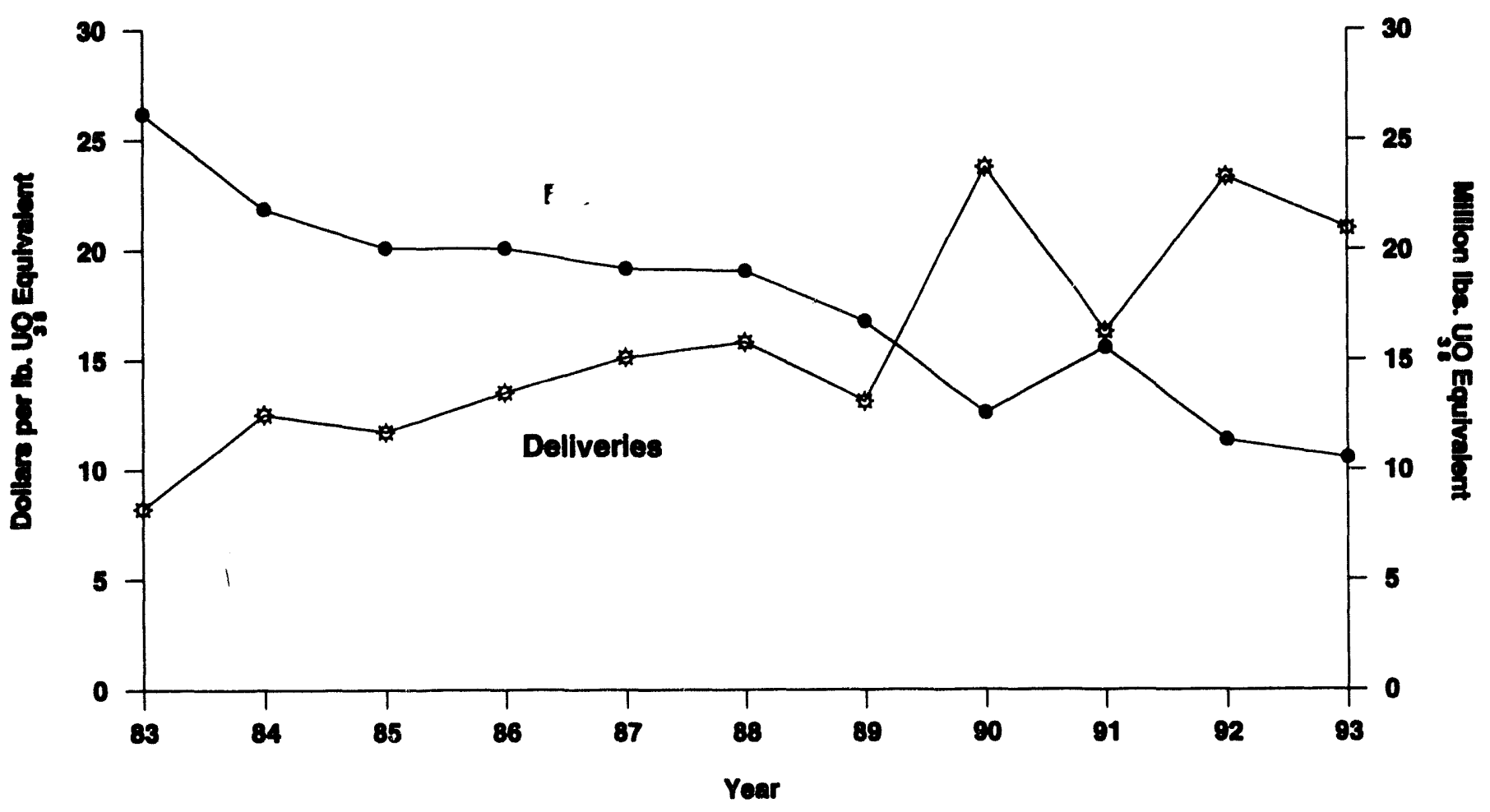

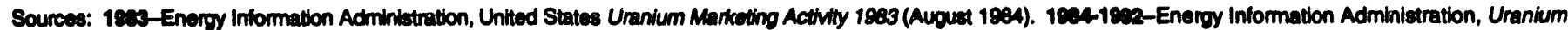
Inctustry Annual 1892 (October 1993). 1903-Energy Intormation Administration, Form ElA-858, "Uranium Industry Annual Sunvey" (1993). 


\section{Uranium Purchases by U.S. Utilities}

There were 37 U.S. utilities that received 31.2 million pounds of $\mathrm{U}_{3} \mathrm{O}_{8} \mathrm{e}$ at a price of $\$ 11.97$ per pound under purchase contracts in 1993. During the previous year, 40 utilities received 32.7 million pounds for $\$ 13.87$ a pound. Two distinct price distributions for 1989 through 1993 are presented in Table 35. Of the 31.2 million pounds $\mathrm{U}_{3} \mathrm{O}_{8}$ e delivered to U.S. utilities in 1993 at a price of $\$ 11.97$ per pound, 3.9 million pounds (12 percent) were of U.S. origin at a price of $\$ 15.53$ per pound. Non-U.S. origin uranium accounted for 27.3 million pounds ( 88 percent) of the deliveries (Table 36 ). Some of this material was in the United States and not imported in 1993.

Table 35. Price Distributions of Uranium Purchases by U.S. Utillitles, 1989-1993

\begin{tabular}{|c|c|c|c|c|c|c|c|c|c|c|}
\hline \multirow[b]{2}{*}{$\begin{array}{l}\text { Dlotir- } \\
\text { bertione }\end{array}$} & \multicolumn{2}{|c|}{1989} & \multicolumn{2}{|c|}{1900} & \multicolumn{2}{|c|}{1901} & \multicolumn{2}{|c|}{1992} & \multicolumn{2}{|c|}{1008} \\
\hline & $\begin{array}{l}\text { Quantity } \\
\text { (million } \\
\text { pounds } \\
U_{0}(0, \theta)\end{array}$ & $\begin{array}{l}\text { Average } \\
\text { Price } \\
\text { ( } \mathbf{p} \text { per } \\
\text { pound } \\
\left.U_{3} O_{0}\right)\end{array}$ & $\begin{array}{l}\text { Quantity } \\
\text { (million } \\
\text { pounds } \\
U, 0, \theta)\end{array}$ & $\begin{array}{l}\text { Average } \\
\text { Price } \\
\text { (\$ per } \\
\text { pound } \\
U_{2} 0 . \theta \text { ) }\end{array}$ & $\begin{array}{l}\text { Quantity } \\
\text { (million } \\
\text { pounds } \\
U, 0, \theta \text { ) }\end{array}$ & $\begin{array}{c}\text { Average } \\
\text { Price } \\
\text { (S per } \\
\text { pound } \\
U, 0,0)\end{array}$ & $\begin{array}{l}\text { Quantty } \\
\text { (million } \\
\text { pounds } \\
U, 0,0)\end{array}$ & $\begin{array}{l}\text { Average } \\
\text { Price } \\
\text { (5 per } \\
\text { pound } \\
\text { U,Oe) }\end{array}$ & $\begin{array}{l}\text { Quantly } \\
\text { (million } \\
\text { pounds } \\
U_{2} \theta_{0} \theta \\
\end{array}$ & $\begin{array}{c}\text { Average } \\
\text { Prlce } \\
\text { (\$ per } \\
\text { pound } \\
\text { U. } 0 \text { - })\end{array}$ \\
\hline \multicolumn{11}{|l|}{ Oetile: } \\
\hline Frst $\ldots .$. & 2.9 & 9.29 & 3.9 & 7.70 & 4.7 & 7.45 & 4.1 & 7.11 & 3.8 & 7.80 \\
\hline Second... & 2.9 & 9.80 & 3.9 & 8.91 & 4.7 & 8.52 & 4.1 & 7.75 & 3.9 & 9.21 \\
\hline Third ..... & 2.8 & 10.57 & 3.9 & 9.13 & 4.7 & 8.83 & 4.1 & 7.98 & 3.8 & 8.67 \\
\hline Fourth .... & 2.9 & 11.77 & 3.9 & 8.59 & 4.7 & 9.31 & 4.1 & 8.56 & 3.0 & 9.80 \\
\hline Fith $\ldots \ldots$ & 2.9 & 15.19 & 3.9 & 10.21 & 4.7 & 10.12 & 4.1 & 9.75 & 3.9 & 8.98 \\
\hline Sixth ..... & 2.9 & 17.33 & 3.8 & 14.09 & 4.7 & 12.67 & 4.1 & 13.64 & 3.9 & 10.09 \\
\hline Seventh .. & 2.9 & 30.21 & 3.9 & 20.72 & 4.7 & 18.66 & 4.1 & 18.80 & 3.8 & 13.81 \\
\hline Elghth .... & 2.8 & 48.18 & 3.9 & 44.60 & 4.7 & 39.10 & 4.1 & 37.37 & 3.8 & 25.32 \\
\hline Total ..... & 23.5 & 19.04 & 31.5 & 15.62 & 37.4 & 14.35 & 32.7 & 13.87 & 31.2 & 11.97 \\
\hline \multicolumn{11}{|l|}{ Quartib": } \\
\hline First $\ldots \ldots$ & 2.2 & 9.87 & 7.1 & 8.66 & 5.7 & 8.27 & 7.3 & 7.58 & 11.5 & 8.29 \\
\hline Second ... & 3.6 & 12.24 & 7.6 & 10.09 & 7.3 & 9.25 & 6.5 & 8.94 & 6.4 & 9.85 \\
\hline Third ..... & 8.4 & 15.33 & 9.3 & 13.17 & 14.7 & 11.83 & 11.1 & 13.03 & 5.5 & 10.86 \\
\hline Fourth .... & 9.4 & 27.10 & 7.5 & 30.87 & 9.8 & 25.43 & 7.8 & 25.05 & 7.8 & 18.41 \\
\hline Total' .... & 23.5 & 18.04 & 31.5 & 15.62 & 37.4 & 14.35 & 32.7 & 13.87 & 31.2 & 11.87 \\
\hline
\end{tabular}

- Octile distribution divides total pounds of uranium dellvered (with a price) into octlles by price and provides the quantily-weighted average price for each octile.

- Quartile distribution divides total pounds of uranium delivered (with a price) into quartiles by each uttilty's aggregate weighted-average price and provides the quantity and average price for each quartile.

Total quantity with a reported price.

Notes: Quantities of uranium are $U, O$, equivalent $(U, O, 0)$ that had a reported price. Prices are quantity-weighted averages per pound $U, O$, equivalent in nominal $U . S$. dollars.

Source: Energy Information Administration, Form ElA-858, Uranium Industry Annual Survey" (1809-1893). 
Table 36. U.S. Utility Purchases of Uranium and Enrichment Servlces by Origin, 1993

\begin{tabular}{|c|c|c|c|}
\hline \multirow[b]{2}{*}{ Origin Country } & \multicolumn{3}{|c|}{ Delliverles } \\
\hline & $\begin{array}{c}\text { Uranium } \\
\text { (million pounds } \\
\cup_{3} \mathrm{O} \text { equivalent) }\end{array}$ & $\begin{array}{l}\text { Enrichment Foed } \\
\text { (million pounds } \\
\mathrm{U}_{3} \mathrm{O}_{2} \text { equivalent) }\end{array}$ & $\begin{array}{r}\text { Separative } \\
\text { Work Units } \\
\text { (million SWU) }\end{array}$ \\
\hline Australla & 1.8 & 1.6 &.- \\
\hline Canada & 14.0 & 11.5 & -. \\
\hline China & 2.9 & 3.5 & $w^{a}$ \\
\hline France & 0 & $w$ & $w^{b}$ \\
\hline Gabon & $w$ & 0.6 & -. \\
\hline Germany & $w$ & $w$ & $w^{c}$ \\
\hline Mongolla & $w$ & 0 & -- \\
\hline Namibia & 0.4 & 0.7 & -. \\
\hline Netherlands & -- & -. & $w^{d}$ \\
\hline Niger & 0 & (ө) & -- \\
\hline NIS' Total & 6.2 & 7.3 & -- \\
\hline Kazakhstan & 1.6 & 1.1 & .- \\
\hline Kyrgyzstan & $w$ & $\mathbf{w}$ & -- \\
\hline Russia & 3.7 & 5.4 & $0.2^{\circ}$ \\
\hline Uzbekistan & $w$ & $\mathbf{w}$ & -- \\
\hline South Africa & $w$ & 1.1 & $0^{h}$ \\
\hline Spain & 0 & $w$ & -- \\
\hline United Kingdom & $w$ & $w$ & $w^{\prime}$ \\
\hline United States & 3.9 & 7.8 & $8.1^{\prime}$ \\
\hline Total $\ldots \ldots \ldots \ldots \ldots \ldots$ & 31.2 & 35.1 & 8.8 \\
\hline
\end{tabular}

- China Nuclear Energy Induetry Corp. enriohment plant, Lanzhou Provinco, Peoples Republic of China.

- Eurod enrichmont plant, Georges Beses, France.

- Unenco entechmome plant, Gronau, Germany.

- Urenco enrichmont plant, Amelo, Nothortands.

Lees than 0.05 million pounds $\mathrm{U}_{3} \mathrm{O}_{6}$ equivalont.

' NIS = Newly Independent States

- Techenabexport (Tenex) enrichment plants located in Angarak, Ruseia; Ekaterinburg, Russia; Kraenoyarek, Rusala; and Tomsk, Rusela.

" Alomic Eneroy Cosporation of South Arrica, Lid. enrichment plant, Valindaba, South Airica.

'Urenco enrichment plant, Capenhuret, United Kingdom.

' DOENSEC enrichment plants, Paducah, Kentucky and Portamouth, Ohlo.

$W=$ Witheld to avoid disclosure of individual company data.

- = Not applicablo.

Noto: Totals may not equal sum of components because of independent rounding.

Source: Energy Information Adminiatration, Form ElA-ses, Unanlum Induatry Amulal Burver"(1893).

\section{Deliveries to Enrichment Suppliers by}

\section{U.S. Utilities}

In 1993, U.S. utilities delivered 35.1 million pounds of uranium feed to enrichment suppliers (Tables 36 and 37). Of the 35.1 million pounds of uranium feed, 32.4 million pounds were delivered to DOE/USEC enrichment plants (7.7 million pounds of U.S. origin material and 24.6 million pounds of foreign-origin material). A total of 2.7 million pounds of uranium feed was deliv- ered to foreign enrichment plants in 1993. Enrichment feed deliveries for U.S. enrichment as a percentage of total deliveries was 92 percent in 1993. In 1993, 8.8 million separative work units (SWU) were purchased by U.S. utilities under enrichment service contracts $(91$ percent from U.S. enrichment and 9 percent from foreign enrichment) (Table 36). Projected feed deliveries for 1994 through 2002 decreased by 25.2 million pounds from those reported in the 1992 survey (Table 38). 
Table 37. Dellverles of Uranlum Feed by U.8. Utilitioe to Enrichment Suppllere, 1993 (Million Pounds $\mathrm{U}_{2} \mathrm{O}$, Equivalent)

\begin{tabular}{|c|c|c|c|}
\hline Enrionment supplles & $\begin{array}{l}\text { Domeatio } \\
\text { Urenlum }\end{array}$ & $\begin{array}{l}\text { Forcien } \\
\text { Urenlum }\end{array}$ & Total \\
\hline Domectic (DOENSEC) Enrichment Plants . . . . . . . . . . & 7.7 & 24.6 & 32.4 \\
\hline Forigen Enrichment Plants $\ldots . .$. & 0.1 & 2.7 & 2.7 \\
\hline Toth $\ldots \ldots \ldots \ldots \ldots \ldots \ldots \ldots \ldots \ldots \ldots \ldots \ldots \ldots$ & 7.8 & 27.3 & 38.1 \\
\hline
\end{tabular}

Note: Totals may not equal eum of components because of independent rounding.

Sounco: Energy Information Adininiatration, Form EIA-858, Uranium Induatry Annual Buner' (1893).

Table 38. Projected Shlpments of Uranlum by Utilities to Domestic and Forelgn Enrlchmont Suppliers, 1904-2003 (Million Pounds $\mathrm{U}_{3} \mathrm{O}$, Equivalent)

\begin{tabular}{|c|c|c|c|c|}
\hline \multirow[b]{2}{*}{ Yeer of Bhioment } & \multicolumn{2}{|c|}{ Amount to be shlpoed } & \multicolumn{2}{|c|}{ 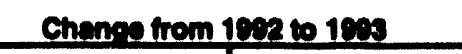 } \\
\hline & $\begin{array}{c}\text { As of } \\
\text { December 31, } 1992 \\
\end{array}$ & $\begin{array}{c}\text { As of } \\
\text { December 31, } 1903\end{array}$ & Anneual & Cumulattue \\
\hline $1804 \ldots$. & 43.4 & 42.7 & -0.6 & -0.6 \\
\hline 1895 & 42.0 & 44.6 & 2.7 & 2.0 \\
\hline $1890 \ldots$ & 48.3 & 44.5 & -3.8 & -1.8 \\
\hline 1897. & 46.9 & 44.7 & -2.1 & -3.9 \\
\hline 1998 . & 48.5 & 45.2 & -3.3 & -7.2 \\
\hline 1800 & 45.8 & 46.4 & -0.4 & -7.6 \\
\hline 2000 & 49.5 & 40.8 & -8.6 & -16.2 \\
\hline $2001 \ldots \ldots \ldots \ldots \ldots \ldots \ldots$ & 46.0 & 49.3 & -2.7 & -18.0 \\
\hline $2002 \ldots \ldots \ldots \ldots \ldots \ldots \ldots \ldots$ & 46.8 & 40.7 & -6.2 & -25.2 \\
\hline $2009, \ldots \ldots+\ldots \ldots$ & NR & 4.4 & $=$ & - \\
\hline
\end{tabular}

NA = Not reported.

$\rightarrow$ Not copillablolo.

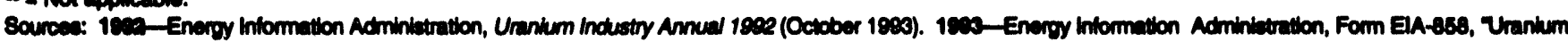
Inctuatry Annud Burver (1093).

\section{Uranium Inventories}

Total commercial inventories decreased by 12.8 million pounds, from 117.3 million pounds $\mathrm{U}_{3} \mathrm{O}_{8} e$ as of December 31; 1992, to 104.4 million pounds as of December 31, 1993 (Table 39). Utility inventories decreased by 11.3 million pounds from 92.1 million pounds as of December 31,1992 , to 80.7 million pounds as of December 31,1993 . The commercial inventories of natural uranium at the end of 1993 are equivalent to less than 2 years of supply for utility enrichment feed deliveries (Figure 17). The Department of Energy (DOE) and United States Enrichment Corporation (USEC) inventories of natural uranium increased from 45.8 million pounds $\mathrm{U}_{3} \mathrm{O}_{8} \mathrm{e}$ in 1992 to 46.7 million pounds in 1993 (Table 40). The amount of enriched uranium held in inventory by the DOE and USEC increased from 23.1 million pounds to 26.9 million pounds. 
Table 39. Commerclal Uranlum Inventoriee at End of Year, 1900-1993 (Million Pounds U,O, Equivalont)

\begin{tabular}{|c|c|c|c|c|c|c|c|c|}
\hline \multirow[b]{2}{*}{ Dres ci Unalum linement } & \multicolumn{4}{|c|}{ vallites } & \multicolumn{4}{|c|}{ All compentes } \\
\hline & 1890 & 1901 & 1802 & 1909 & 1800 & 1001 & 1892 & 1003 \\
\hline \multicolumn{9}{|l|}{$U_{2} \mathbf{O}_{\mathbf{z}}$} \\
\hline Domeatic...$\ldots \ldots \ldots \ldots \ldots$ & 17.0 & 13.8 & 12.6 & 10.0 & 33.6 & 27.7 & R24.4 & 21.7 \\
\hline Foralon $\ldots \ldots \ldots \ldots \ldots \ldots \ldots$ & 8.8 & 11.0 & 13.4 & 16.3 & 12.1 & 13.4 & R19.8 & 20.6 \\
\hline Tow $\ldots . . . \ldots \ldots \ldots . . . \ldots$ & 28.8 & 24.8 & 28.0 & 20.3 & 46.7 & 41.1 & PMA.3 & 422 \\
\hline \multicolumn{9}{|l|}{ Nemural UF:" } \\
\hline Domectlo .. & 6.1 & 1.8 & 1.6 & 1.6 & 6.4 & 2.2 & 2.0 & 2.2 \\
\hline Fordign $\ldots \ldots \ldots \ldots \ldots \ldots$ & 2.2 & 1.8 & 4.0 & 3.4 & 2.4 & 2.0 & 4.2 & 4.0 \\
\hline Tot $\ldots . . . \ldots \ldots \ldots \ldots . . . .$. & 8.3 & 3.7 & 8.8 & 4.0 & 8.8 & 4.2 & 8.2 & 8.2 \\
\hline \multicolumn{9}{|l|}{ Natural UF, Under Ueces } \\
\hline \multicolumn{9}{|l|}{ Acresmente } \\
\hline Domeatlc .................. & 22.6 & 28.2 & 18.0 & 11.7 & 23.8 & 25.5 & 18.1 & 12.0 \\
\hline Forelon $\ldots \ldots \ldots \ldots \ldots \ldots$ & 4.7 & 7.9 & 8.9 & 9.3 & 6.1 & 7.9 & 8.8 & 0.5 \\
\hline Total .................... & 27.3 & 39.2 & 29.0 & 21.1 & 20.0 & 33.6 & 27.0 & 21.5 \\
\hline \multicolumn{9}{|l|}{ Netural UF, at Enrlehero" } \\
\hline Domeetic ................. & 7.4 & 3.3 & R1.9 & 1.0 & 7.4 & 5.0 & R1.9 & 1.5 \\
\hline Forelon...$\ldots \ldots \ldots \ldots \ldots$ & 3.3 & 5.8 & $\mathbf{R 6 . 3}$ & 4.4 & 3.3 & 5.8 & A6.3 & 5.0 \\
\hline Total $\ldots \ldots \ldots \ldots \ldots \ldots \ldots$ & 10.7 & 0.1 & 8.2 & 8.4 & 10.7 & 10.7 & 82 & 6.8 \\
\hline \multicolumn{9}{|l|}{ Enrlehed UF, at Enrichers } \\
\hline Domectic ......... & NR & 1.3 & 1.6 & 1.6 & NR & 1.3 & 1.8 & 1.6 \\
\hline Forelon $\ldots \ldots \ldots \ldots \ldots \ldots \ldots$ & NA & 1.0 & 0.8 & 0.7 & NR & 1.0 & 0.0 & 0.8 \\
\hline Total $\ldots \ldots \ldots \ldots \ldots \ldots \ldots$ & - & 2.3 & 2.8 & 2.3 & - & 2.3 & 2.5 & 2.4 \\
\hline \multicolumn{9}{|l|}{ Enriched UF, . . . . . . . . . . . . . } \\
\hline Domestic ................ & 6.4 & 4.2 & 3.2 & 1.6 & 7.5 & 5.0 & 4.4 & 3.0 \\
\hline Fordglon $\ldots \ldots \ldots \ldots \ldots \ldots$ & 4.0 & 4.6 & R5.8 & 7.8 & 7.3 & 5.8 & R10.7 & 11.5 \\
\hline Total $\ldots \ldots \ldots \ldots \ldots \ldots \ldots$ & 10.4 & 8.8 & ค9.0 & 9.6 & 14.8 & 10.8 & A18.1 & 14.4 \\
\hline \multicolumn{9}{|l|}{ Fabrlented Fuel (Enriched UFd) } \\
\hline Domestic ................. & 12.3 & 7.6 & R8.4 & 6.2 & 12.3 & 7.6 & R8.4 & 6.2 \\
\hline Forelgn...$\ldots \ldots \ldots \ldots \ldots$ & 7.7 & 8.4 & A5.6 & 5.1 & 7.7 & 8.4 & R5.6 & 6.1 \\
\hline Total .................... & 20.0 & 16.0 & A14.0 & 11.3 & 20.0 & 16.0 & A14.0 & 11.3 \\
\hline \multicolumn{9}{|l|}{ Total Inventorise } \\
\hline 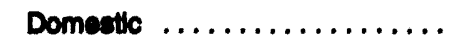 & 71.8 & 57.3 & R47.1 & 33.7 & 81.1 & 74.4 & $\mathbf{R} 60.7$ & 48.1 \\
\hline Forelon .................. & 30.8 & 40.6 & P45.0 & 47.1 & 38.0 & 44.3 & R68.6 & 66.3 \\
\hline 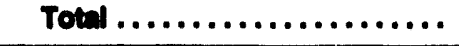 & 102.7 & $\boldsymbol{9 8 . 0}$ & R92.1 & 80.7 & 120.1 & 118.7 & A117.3 & 104.4 \\
\hline
\end{tabular}

$U F_{0}=$ Uranlum hexalluoride.

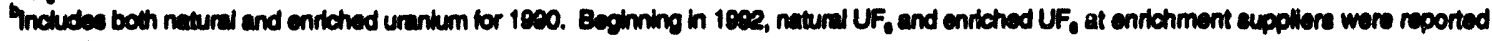
expanately.

$R=$ Revised data. NR $=$ Nol Reportad.

Note: Totws may not equal sum of components because of independent rounding.

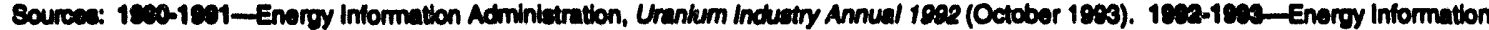
Adminietration, Form EAA-868, Uranlum Inctuetry Annual Survoy" (1803). 
Table 40. Commerclal and U.S. Government Inventories of Natural and Enrlched Uranlum as of End of Year, 1990-1993

(Million Pounds $\mathrm{U}_{3} \mathrm{O}_{2}$ Equivalent)

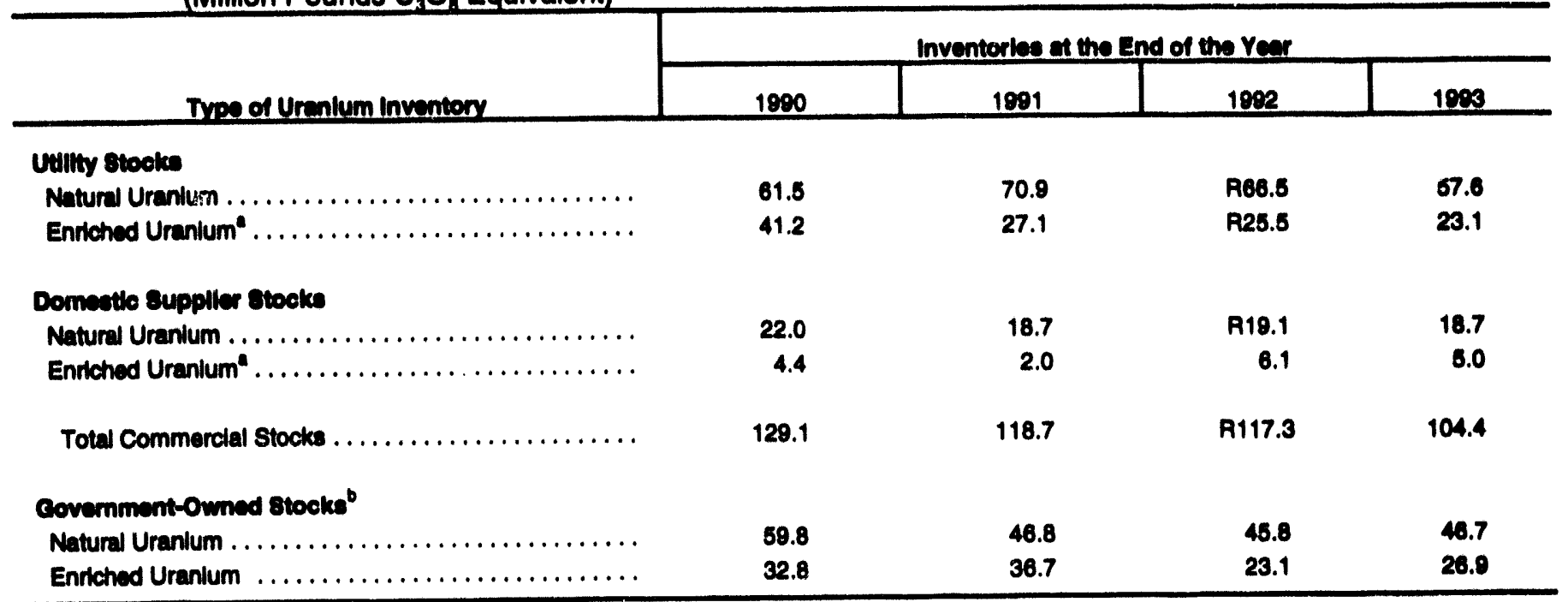

Tnciudas amounts reported as inventories of UF, at Enitichment 8uppliers.

incudies emounts reported as inventories oy DOE and the United States Enrichment Corporation (USEC) for 1893.

R = Rovieed data.

Note: Total may not equal sum of components because of independent rounding.

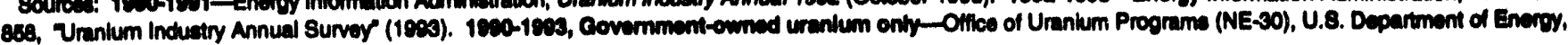
and the United States Enrichment Corporation (USEC).

Figure 17. Commercial Inventories of Uranium for 1993 and Utility Enrichment Feed Dellveriee for 1994-1995 as of December 31, 1993

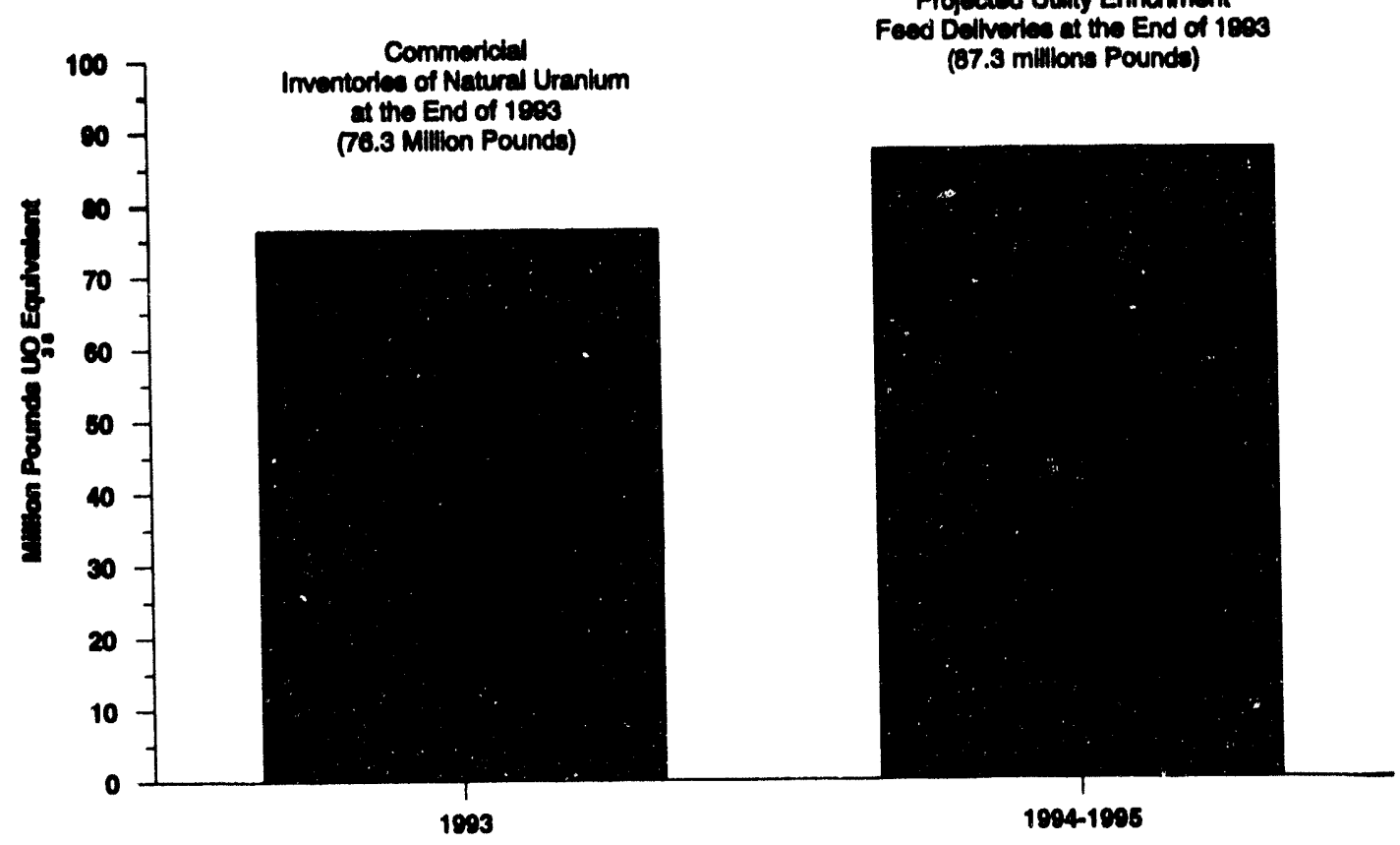

Note: Values for Projected Utility Enriohment Feed Deliveries for the years Indicated equal the amounts to be shipped in Table 38 8ouroo: Energy Information Administration, Form ElA-858, "Uranlum Induatry Annual Burvey" (1983). 


\section{Uranium Used in Fuel Assemblies}

The total amount of new uranium fuel loaded into U.S. nuclear reactors during 1993 was 45.1 million pounds $\mathrm{U}_{3} \mathrm{O}_{2}$, as reported by utilities and reactor operators. This was 2.2 million pounds $\mathrm{U}_{3} \mathrm{O}_{6}$ e more than in 1992. These quantities do not include any fuel rods removed from reactors and later reloaded into the reactor.

\section{Secondary Market Activities}

Secondary market transactions include sales, exchanges, and loans of uranium other than direct sales by suppliers to U.S. utilities or direct imports by U.S. utilities. For 1993, utility exchanges and net loans of uranium with suppliers totaled 3.8 million pounds $\mathrm{U}_{3} \mathrm{O}_{8} \mathrm{e}$. Utility sales to suppliers totaled 2.1 million pounds. Intersupplier transactions totaled 41.9 million pounds $\mathrm{U}_{3} \mathrm{O}_{8} \mathrm{e}$ in 1993. Intersupplier sales were 15.3 million pounds; exchanges were 12.2 million pounds; and loans were 14.4 million pounds. Interutility transactions totaled 0.6 million pounds $\mathrm{U}_{3} \mathrm{O}_{5} e$ in 1993.

\section{Anticipated Uranlum Market Require- ments of U.S. Utilities}

\section{Unfilled Uranlum Requirements}

Unfilled requirements are the additional natural uranium that utilities need to purchase after considering their total future enrichment feed delivery requirements, less inventory drawdowns and deliveries under existing procurement contracts. Unfilled requirements also include purchases necessary to maintain a desired level of inventory coverage.

Annual unfilled uranium requirements for reactors in operation or under construction for 1994 through 2003 are reported, as of the end of 1993, to be 264.3 million pounds $\mathrm{U}_{3} \mathrm{O}_{8} \mathrm{e}$ (Table 41). Unfilled requirements for the period 1994 through 2002 show a decrease, from 234.9 million pounds reported at the end of 1992 , to 217.8 million pounds reported at the end of 1993.

Table 41. Unfilled Uranlum Requirements of Utilitios, 1994-2003 (Million Pounds U,O, Equivalent)

\begin{tabular}{|c|c|c|c|c|c|c|}
\hline \multirow[b]{2}{*}{ Yeer } & \multicolumn{2}{|c|}{ As of December 31,1901} & \multicolumn{2}{|c|}{ As of Docember a1, 160 ? } & \multicolumn{2}{|c|}{ 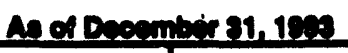 } \\
\hline & Annual & Cumulitive & Annul & Cumutettive & Annual & Cumulative \\
\hline 1804 & 9.3 & 9.3 & 6.2 & 6.2 & 2.8 & 2.6 \\
\hline $1805 \ldots$ & 17.4 & 28.6 & 8.8 & 15.0 & 6.8 & 9.1 \\
\hline $1808 \ldots \ldots$ & 22.0 & 49.5 & 16.4 & 30.4 & 12.4 & 21.6 \\
\hline $1897 \ldots \ldots \ldots$ & 27.9 & 77.4 & 22.2 & 62.6 & 20.4 & $\mathbf{4 2 . 0}$ \\
\hline $1898 \ldots \ldots$. & 39.8 & 118.0 & 29.8 & 82.4 & 25.8 & 67.8 \\
\hline $1890 \ldots \ldots .$. & 41.7 & 157.7 & 32.4 & 114.0 & 28.3 & $\infty 0.1$ \\
\hline 2000 . & 40.3 & 189.0 & 38.1 & 162.0 & 32.0 & 128.0 \\
\hline $2001 \ldots \ldots \ldots$ & 45.2 & 243.2 & 40.8 & 193.7 & 40.0 & 178.0 \\
\hline $2002 \ldots \ldots \ldots \ldots \ldots \ldots \ldots \ldots \ldots$ & - & - & 41.1 & 234.0 & 42.0 & 217.8 \\
\hline $2003 \ldots \ldots \ldots \ldots$ & - & - & - & - & 46.5 & 264.3 \\
\hline
\end{tabular}

Note: Totale may not cqual eum of componerts becaues of independent rounding.

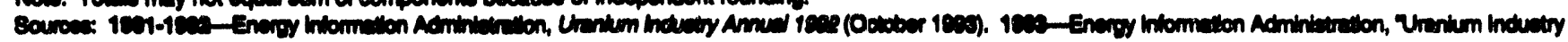
Amual Bunver (1000). 


\section{Uranium Requirements}

Data from various parts of this chapter are combined in Table 42 to produce an aggregate picture of selected aspects of U.S. uranium requirements. Anticipated market requirements are computed by summing the quantities of uranium under contract and unfilled requirements. Utility contracts for uranium include firm and optional domestic purchase commitments and imports.

The two components of anticipated market requirements are shown in Figure 18. Unfilled requirements constitute a small portion of anticipated market requirements in 1994. However, they increase to 48 percent of total anticipated requirements by 1997 and to 93 percent by
2002. Also shown in Figure 18 is the schedule reported by U.S. utilities for enrichment feed deliveries to their enrichment suppliers. For the years 1994 through 2000, utilities apparently plan to meet a portion of their enrichment feed deliveries by drawing down uranium inventories.

Potential Inventory Drawdown represents the difference between anticipated market requirements and reported enrichment feed deliveries. When reported enrichment feed deliveries in a year exceed anticipated market requirements, a potential can exist for drawdown of inventory. When feed deliveries are less than anticipated market requirements, a potential can exist for build-up of inventory.

Table 42. Anticipated Uranium Market Requirements of Utilities, 1994-2002, as of December 31, 1993 (Million Pounds $\mathrm{U}_{3} \mathrm{O}_{8}$ Equivalent)

\begin{tabular}{|c|c|c|c|c|}
\hline Yeer of Dellvery & $\begin{array}{l}\text { Quantity of } \\
\text { Uranlum } \\
\text { Under Contrect }\end{array}$ & $\begin{array}{c}\text { Unfilied } \\
\text { Requiliemente }\end{array}$ & $\begin{array}{l}\text { Anticlpeted } \\
\text { Market } \\
\text { Reguirements }\end{array}$ & $\begin{array}{l}\text { Propectied } \\
\text { Enrlehment } \\
\text { Feed Dellwerles }\end{array}$ \\
\hline $1904 \ldots$. & 34.7 & 2.6 & 37.2 & 42.7 \\
\hline $1895 \ldots$ & 34.8 & 6.5 & 41.3 & 44.6 \\
\hline $1986 \ldots \ldots \ldots \ldots \ldots \ldots \ldots$ & 30.0 & 12.4 & 42.4 & 44.5 \\
\hline $1897 \ldots$ & 22.1 & 20.4 & 42.5 & 44.7 \\
\hline $1998 \ldots \ldots \ldots \ldots \ldots \ldots \ldots$ & 17.8 & 25.8 & 43.6 & 45.2 \\
\hline $1980 \ldots$ & 11.8 & 28.3 & 40.1 & 45.4 \\
\hline $2000 \ldots \ldots \ldots \ldots \ldots \ldots$ & 7.4 & 32.9 & 40.3 & 40.8 \\
\hline$\ldots \ldots \ldots$ & 5.3 & 46.9 & 52.2 & 43.3 \\
\hline 3002 & 3.3 & 42.0 & 45.3 & 40.7 \\
\hline
\end{tabular}

Nots: Totals may not equal eum of components because of independent rounding.

Source: Enorgy Information Adminiatration, Form EIA-858, Uranium Industry Annual Surver" (1993). 
Flgure 18. Anticlpated Uranlum Market Requirements of Utilitiee, 1994-2002, as of December 31, 1993

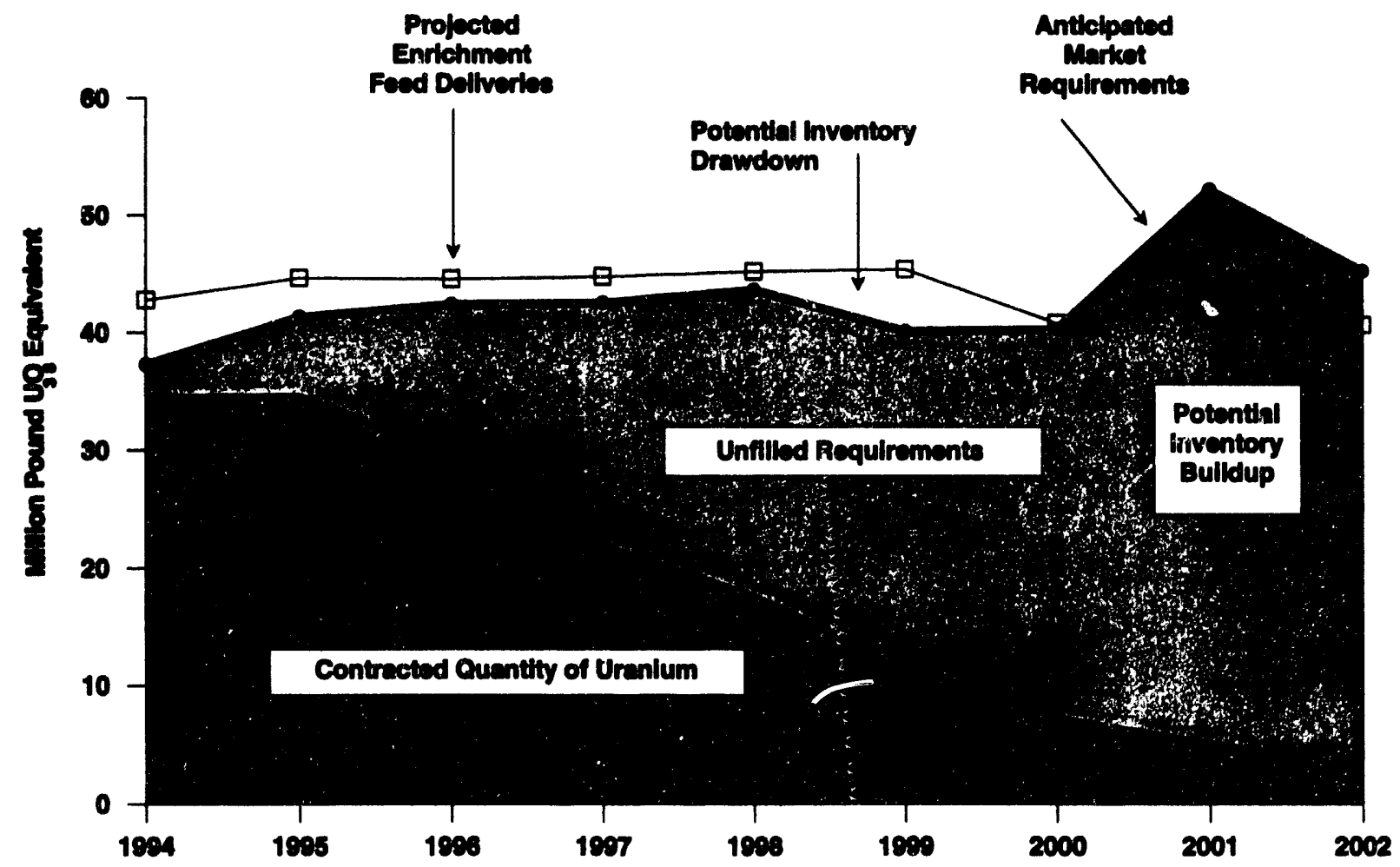

Note: Values for Projected Enrichment Feed Dellveries equal the amount to be sisilpped shown in Table 38. Values for contracted quantities and unfilled requirements are cumulative.

8ource: Enorgy Information Administration, Form EIA-858, "Uranium Industry Annual Survoy (1893). 


\title{
Appendix A
}

\author{
Survey \\ Methodology
}

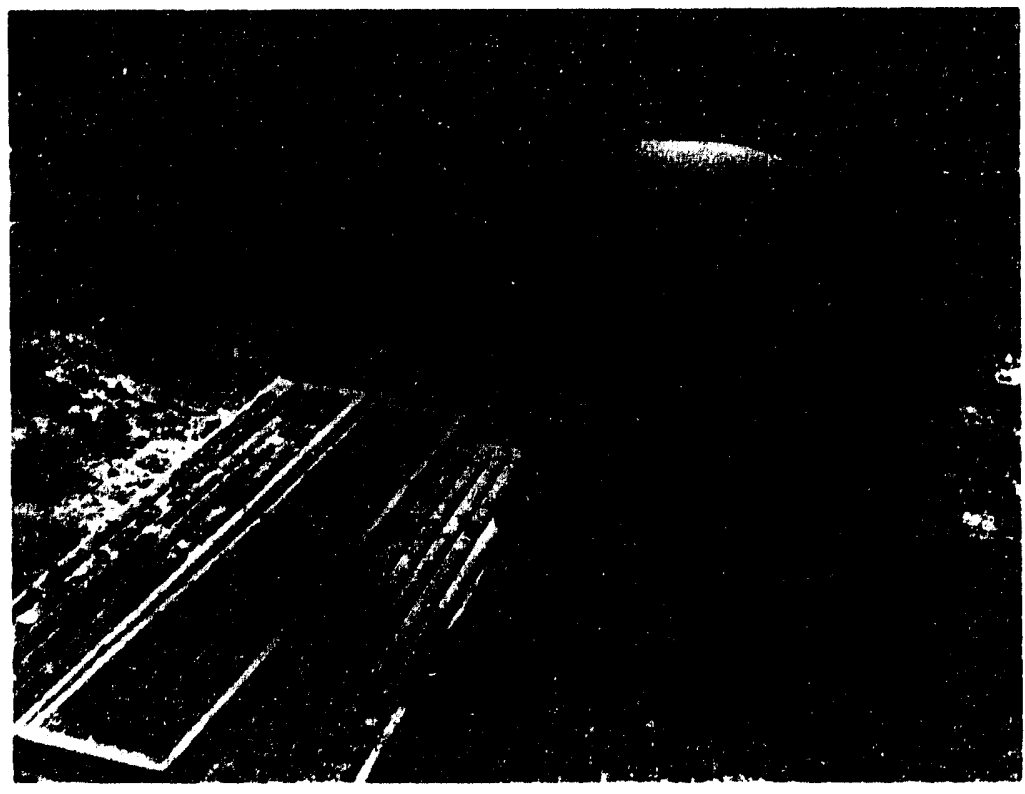

Diamond ditl con, cbialnad by dilling through a subsurtace ore horizon, can provide information about the epatid didribution of uranium mineralization and other dotalls of host-rock

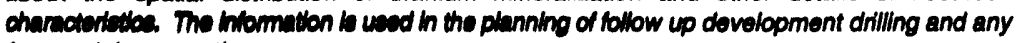
cuture mining coperations. 


\section{Appendix A}

\section{Survey Methodology}

\section{Survey Design}

The 10th comprehensive survey of the U.S. uranium industry was conducted in 1994 by the Energy Information Administration (EIA) using the "Uranium Industry Annual Survey," Form EIA-858. Data were collected from all companies involved in the U.S. uranium industry. The survey form was mailed to these firms in January 1994. The data reported in this publication were developed from the Form EIA-858 1993 survey and predecessor data bases.

Respondents to the "Uranium Industry Annual Survey" were asked to provide data current to the end of 1993 about the following: uranium raw materials activities (including land holdings, exploration and development activities, uranium-bearing properties and resources, uranium mines, uranium processing facilities, and uranium industry employment for exploration, mining, milling, processing, and reclamation); uranium marketing activities (including contracts, contract prices, delivery schedules, uranium inventories, enrichment feed deliveries, unfilled market requirements, uranium used in fuel assemblies, and purchases of enrichment services.)

The data collected on Form EIA-858 are subject to various sources of error. These sources are: (1) coverage (the list of respondents may not be complete or, on the other hand, there may be double counting); (2) nonresponse (all units that are surveyed may not respond or may not provide all the information requested); (3) respondents (respondents may commit errors in reporting the data); (4) processing (the data collection agency may omit or incorrectly transcribe a submission); (5) concept (the data collection elements may not measure the items they were intended to measure); and (6) adjustments (errors may be made in estimating values for missing data).
Because the "Uranium Industry Annual Survey" is not a sample survey, the estimates shown in this report are not subject to sampling error. ${ }^{1}$ Although it is not possible to present estimates of non-sampling error, precautionary steps were taken at each stage of the survey design to minimize the possible occurrence of these errors. The steps are described below, with the error they were designed to minimize shown in parenthesis.

\section{Survey Universe and Frame (Coverage Errors)}

The survey universe includes all companies involved in the U.S. uranium industry. The universe includes all firms meeting one or more of the following criteria: (1) are controllers or were controllers during any portion of 1993, or are identified in EIA records as the most recent controllers, of uranium properties, mines, mills, or plant; (2) involved as controllers of uranium exploration and development ventures in the United State; (3) incurred uranium exploration expenditures in 1993 or plan such expenditures in 1994; (4) hold uranium reserves; (5) control uranium mining properties; (6) control commercial uranium extraction operations; and (7) purchase, sell, held, or own domestic- or foreign-origin uranium; offered uranium enrichment services; imported or exported uranium; and (utilities only) purchased uranium enrichment services from an enrichment supplier. (See Form EIA-858 in Appendix D for an explanation of these categories.)

The respondent list used for the Form EIA-858 survey was developed from a frame of all establishments known to meet the selection criteria. The frame of potential respondents was compiled from previous surveys and from information in the public domain. The frame was in-

\footnotetext{
'Sampling error is a measure of the variation that occurs by chance because a sample rather than a complete enumeration of units is surveyed.
} 
tended to cover the following: all utilities owning nuclearfueled generating stations; uranium converters, enrichers, and fuel fabricators; uranium traders and brokers; large and small companies actively engaged in exploration, development, or extraction in the U.S. uranium industry; and companies holding all large properties with uranium reserves. Companies meeting these criteria include: those involved in exploration, development, mining, milling, and trading of uranium; landowners; fuel converters, enrichers, and fabricators; and utilities with whole or partial ownership in operating or planned uranium-fueled power plants.

\section{Survey Procedures (Nonresponse)}

The survey forms were sent via first class mail to ensure their receipt only by the proper respondent organization. If the U.S. Postal Service was unable to deliver the survey form, the corrected address was obtained where possible. In a few instances, businesses that had reported in earlier surveys were no longer operating. All known companies currently conducting business in the U.S. uranium industry were contacted during this survey.

Form EIA-858, "Uranium Industry Annual Survey," is a self-administered questionnaire requesting data about many areas of company operations. The scope of the questions is necessarily broad, and self-reporting of company-specific data is required.

Cooperation from industry on the 1993 survey was, as in previous years, excellent. A large number of respondents replied to the form within the specified deadlines. Those that had not responded by the due dates (March 1st for Schedules A and B) were telephoned to encourage submission of the forms, and those calls resulted in the submission of most of the remaining forms. In addition, a followup letter was mailed to nonrespondents requesting compliance with the survey by May 15 th. Subsequently, telephone calls were made to obtain forms not yet submitted. In a few instances, company data were collected through telephone conversations, followed by submissions of the survey forms.

In order to reduce the burden to the respondents, every effort was made to identify the properties, mines, mills, plants, and long-term contracts that form the bulk of responses to the 1992 survey. Selected data elements for these items that were reported by industry companies on the previous year's forms were preprinted on the 1993 form.

\section{Data Editing, Analysis, and Processing (Respondent and Processing Errors)}

The survey forms are logged in and reviewed by agency personnel prior to data entry into the Uranium Industry Annual System, an automated data base containing all current and historical data from each company's submissions. The data base is maintained on the EIA computer facility in Washington, DC. After entry into the data base, a copy of each section of the Form EIA-858 was distributed to the Survey Management Division analyst responsible for that section. The submissions were checked for internal consistency, and the reported data were compared with previous collections of similar data. After reviewing these submissions, the analyst consulted with the reporting company, as needed, to resolve data problems and to confirm any corrections of the data.

Data areas that were reviewed and the corrections that were made differed from company to company. Most represented different interpretations of the data item definitions. No data in the data base were changed without first consulting with the reporting company. Computer edits were also used to identify keypunch errors, out-of-range values, and unlikely data combinations. These also were either corrected to represent the data reported on the submissions or were changed only after confirming the corrected values by telephone conversations with company representatives. Data coding and entry errors were eliminated by proofing data after entry. All changes to reported data are documented.

\section{Response Rates}

Schedule A of Form EIA-858 was mailed to 76 firms, Schedule B was mailed to 134 firms. The response statistics for the 1993 survey are shown in Table A1. Overall, 92 percent of the schedules that were mailed to industry companies were returned with the data requested on the form or marked as not applicable to the company for this survey year.

\section{Missing Data}

Some omissions of data were identified during the prescreening and editing of the data. Most omitted data elements fell into two categories: withheld because of 
contractual constraints or contracts that were under litigation, or inadvertent omissions. Respondents were contacted regarding omissions to obtain the data or to verify that it could not be reported. Only confirmed company-reported data are contained in the data base and included in this report.

\section{Data Revisions}

The Office of Coal, Nuclear, Electric and Alternate Fuels, Energy Information Administration, has adopted the following policy for review and correction (revision) of

Table A1. Response Statletlce for the 1993 Uranlum Industry Annual Survey

\begin{tabular}{|c|c|c|}
\hline \multirow[b]{2}{*}{ Response Status } & \multicolumn{2}{|c|}{ Schedule } \\
\hline & A & B \\
\hline Survey Schedules Malled Out & 76 & 134 \\
\hline 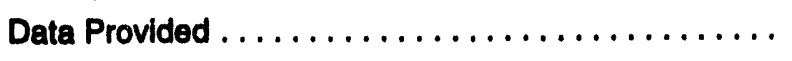 & 57 & 82 \\
\hline Reported as Not Applicable & 19 & 52 \\
\hline
\end{tabular}

ancludes elght non-respondents stating that in 1993 the company did not meet any of the criteria for inclusion in the survey.

Source: Energy Information Administration, Form ElA-658, "Uranlum Industry Annual Survey" (1993).

data it collects and publishes. The policy covers revisions to prior published data. This new policy was initially implemented with the publication of the Uranium Industry Annual 1992.

1. Annual survey data are published either as preliminary or final when they first appear in a data report. Data released as preliminary will be identified as such. When necessary, preliminary data will be revised and declared to be final at the next publication of that data.

2. Monthly and quarterly survey data are published initially as preliminary data. They will be revised only after the completion of the data collection cycle for the full 12-month survey period. Revisions will not be made to monthly or quarterly data prior to this time.

3. The magnitude of historical data revisions experienced will be included in each data report to inform the reader about the accuracy of the data presented.

4. Revisions to data published as final will be made only in the event that newly available information would result in a change to published data of greater than one percent difference at the national level. Revisions for changes of lesser magnitudes will be made at the discretion of the Office Director.
All data, except for uranium inventories data are published as final data. Data on uranium inventories for the survey year are published as preliminary data because survey respondents are requested to make changes to their prior year inventories data, if necessary, when reporting inventories data for the current survey year. These revised inventory data are indicated by an " $R$ " in front of the revised data cell.

Changes to the prior year's total uranium inventory figures based on revisions reported on Form EIA-858 have been: for $1992,0.1$ million pounds $\mathrm{U}_{3} \mathrm{O}_{8}(<0.1$ percent); 1991,1.3 million pounds $\mathrm{U}_{3} \mathrm{O}_{8}(-1.1) ; 1990,-3.1$ million pounds $\mathrm{U}_{3} \mathrm{O}_{8}(-2.3) ; 1989,1.0$ million pounds $\mathrm{U}_{3} \mathrm{O}_{8}(0.7) ; 1988$, 0.1 million pounds $\mathrm{U}_{3} \mathrm{O}_{8}(<0.1) ; 1987,0.3$ million pounds $\mathrm{U}_{3} \mathrm{O}_{8}(0.2)$; and 1986, 0.4 million pounds $\mathrm{U}_{3} \mathrm{O}_{8}(0.2$ percent).

\section{Nondisclosure of Data}

To protect the confidentiality of individual respondents' data, a policy was implemented to ensure that the reporting of survey data in this publication would not associate those data with a particular company. This is in compliance with EIA Standard No. 88-05-06, "Nondisclosure of Company Identifiable Data in Aggregate Cells." In tables where the nonzero value of a cell is composed of data from fewer than three companies or if a single company dominates a table-cell value so that the publication of the value would lead to identification of 
a company's data, then the EIA classifies the cell value as "sensitive," and the cell value is withheld ("W") from publication. Within a table with a sensitive cell value, selected values in other cells of the table are also withheld, as necessary, so that the sensitive cell value cannot be computed using the values in published cells.
A sensitive table-cell value can be reported, if permission is first obtained from each company (whose data contribute to the sensitivity) to publish the value and if the company believes that publishing the value would not harm its competitive position. This is the only exception to the application of EIA Standard No. 88-05-06 in this report. 


\title{
Appendix B
}

\author{
Technical Notes
}

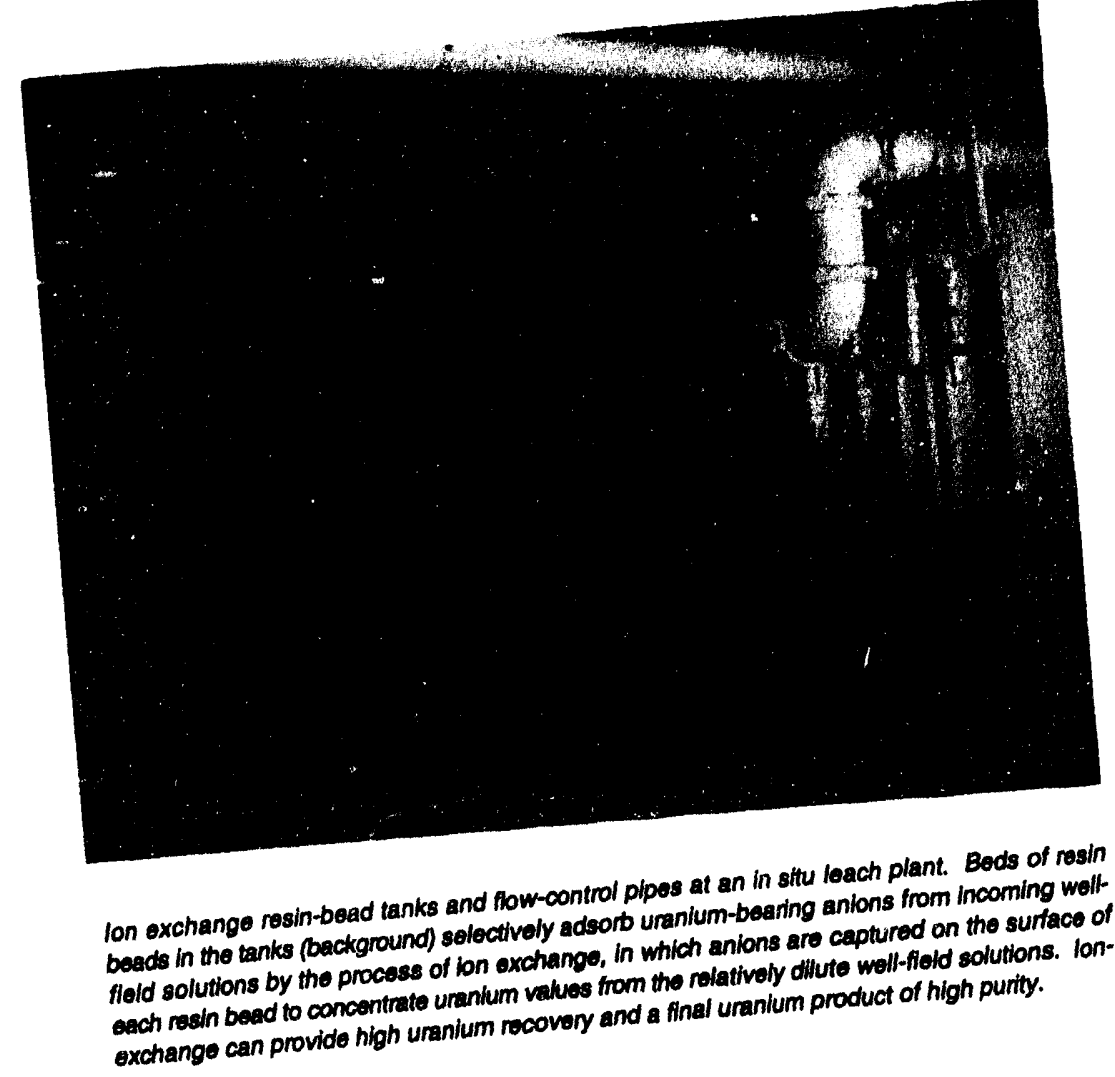




\section{Appendlx B}

\section{Technical Notes}

\section{History and Legal Authority}

From August 1942 through 1946, the Manhattan Engineer District (MED), under the U.S. Army Corps of Engineers, was responsible for development of nuclear weapons. ${ }^{1}$ In that role, MED administered U.S. uranium procurement programs along with its nuclear research and development, engineering, and production operations. ${ }^{2}$ The Atomic Energy Act, signed on August 1, 1946, resulted in the establishment of the Atomic Energy Commission (AEC). By Executive Order 9816, the Government-owned facilities and functions of MED were transferred to the AEC at midnight December 31, 1946. The following is quoted from a 1982 DOE publication. ${ }^{3}$

Procurement of uranium concentrates by the AEC spanned the period from 1947 through 1970. During those years, in definable stages, the market for uranium concentrates changed from a monopsony with the Federal Government as the only buyer, to a completely commercial market with no Government purchases. From the viewpoint of the Government as a consumer, the foreseeable supply of uranium increased from desperately short of that which was required for defense needs, to adequate, to surplus. Procurement policies and contracting practices were adopted, implemented, and modified in response to the Government's changing needs and the perceived lack or adequacy of uranium supplies with which to meet them.

The AEC procurement policies and practices were not dictated solely by its defense needs, however. The agency was also guided by provisions of the Atomic Energy Acts of 1946 and
1954, which were designed to foster development and utilization of atomic energy for peaceful purposes. Therefore, procurement policies also reflected concern for fostering and maintaining a producing uranium industry which would be able to supply the nation's expected uranium requirements for private nuclear power development.

The Atomic Energy Act of 1954 (Public Law 83-703) eased the Government's control over nonmilitary uses of atomic energy by making lawful the private development and ownership of reactors. The Act stipulated that the fuel to power privately owned reactors could be obtained only from the AEC through lease arrangements. By 1963, advances had taken place to further the commercial viability of nuclear power, and many interest groups contended that nuclear fuels should be allowed to compete with other fuels in the marketplace.

Legislation to permit private ownership of nuclear fuels was passed in 1964 in the form of the Private Ownership of Special Nuclear Materials Act (Public Law 88-489). This Act allowed the AEC to provide toll-paid enrichment services for privately owned uranium. It also authorized the AEC to limit the offering of enrichment services for foreign-origin uranium owned by domestic customers to the extent necessary to maintain a viable domestic uranium industry. The latter provision has been the authority upon which the AEC and successor agencies have monitored the status of the U.S. uranium industry.

Public Law No. 97-415, the Nuclear Regulatory Commission (NRC) Authorization Act of 1983 enacted on January 4, 1983, further strengthened the Federal Gov-

\footnotetext{
'R.G. Hewlett and O.E. Anderson, Jr., "A History of the United States Atomic Energy Commission," The New World, 1939-1946, Volume 1 (University Park, Pennsylvania: The Pennsylvania State University Press, 1962), p. 82.

${ }^{2}$ U.S. Department of Energy, Summary History of Domestic Uranium Procurement Under U.S. Atomic Energy Commission Contracts, Final Report, GJBX-220(82) (Grand Junction, Colorado, October 1982), p. 3.

U.S. Department of Energy, Summary History of Domestic Uranium Procurement Under U.S. Atomic Energy Commission Contructs, GJBX-220(82) (Grand Junction, Colorado, October 1982), pp. 3-4.
} 
ernment's role in monitoring the status of the U.S. uranium industry. This law amended the Atomic Energy Act of 1954 by adding Section 170B, which required the Secretary of Energy to determine annually, for the years 1983 through 1992, the viability of the domestic uranium industry.

Determination of the uranium industry's viability requires a continuing review of the industry's status and prospects. Reports on domestic uranium raw materials and marketing activities have been published since 1968, first under the direction of the AEC, later by the Energy Research and Development Administration, then by the Assistant Secretary for Nuclear Energy, Office of Uranium Enrichment and Assessment in the U.S. Department of Energy (DOE), and more recently by the Energy Information Administration (EIA). The legal authority for Form EIA-858, "Uranium Industry Annual Survey," is stated on the form as follows:

Data on this mandatory survey are collected under authority of Section 170B of the Atomic Energy Act of 1954 as amended (42 U.S.C. 790a) and the Federal Energy Administration Act of 1974 (15 U.S.C. 2210b).

On October 24, 1992, the Congress enacted the Energy Policy Act of 1992 (EPACT 1992), Public Law 102-486. This law provides under Subtitle B, 42 USC \& 2296b-4, Sec. 1015, that:

... the owner or operator of any civilian nuclear power reactor shall report to the Secretary (of Energy), acting through the Administrator of the Energy Information Administration, for activities of the previous fiscal year-

(1) the country of origin and the seller of any uranium or enriched uranium purchased or imported into the United States either direc:ly or indirectly by such owner or operator; and

(2) the country of origin and the seller of any enrichment services purchased by such owner or operator.

The information is required to be made available to the Congress annually.

\section{Uranium and the Uranlum Industry: A Brief Description}

Prior to 1942, uranium for domestic consumption was obtained from ores that were mined primarily for their associated radium and vanadium. "The radium was used in medical therapy; the vanadium was used primarily to improve the metallurgical properties of steel, cast iron, and other metals. The uranium was used in manufacturing glass and ceramics to produce yellow-tobrown colors; it was also used in making special alloys of steel, copper, and nickel.

Since passage of the Atomic Energy Act of 1954, uranium has been produced primarily as a fuel for nuclear reactors. Heat produced by the fissioning of $U^{235}$ in a reactor is used to generate steam, which is then used to generate electricity. One pound of natural uranium can produce as much energy as about 14,000 pounds of coal. Uranium is also used in the production of various radioactive isotopes for medical and other applications and for scientific research.

The average concentration of uranium in the earth's crust is approximately 2 parts per million. Uranium is more abundant than such "common" elements as mercury, silver, and gold. Many rocks contain minor quantities of uranium, and economically important quantities occur in naturally formed concentrations of minerals such as pitchblende, uraninite, coffinite, and carnotite. Pitchblende, which contains various uranium oxides, is the richest uranium ore mineral.

In the United States, most uranium deposits occur in sandstone host rocks. Significant deposits also occur in mineralized breccia in solution-collapse structures and as veins and fracture fillings in metamorphic and granitic rocks, and, to a lesser extent, in volcanic rocks which host lower-grade deposits. Uranium deposits in sandstones commonly consist of finely divided uranium mineral grains that fill pore spaces, and the uranium can replace some primary mineral grains and cementing materials of the host rock. Other metals associated with uranium in some deposits are vanadium, copper, selenium, molybdenum, beryllium, and chromium.

Exploration for uranium deposits can involve searching for near-surface deposits as well as deposits at depths of 
several thousand feet. A principal technique in uranium exploration involves the measurement of radioactivity in holes drilled to evaluate a prospective host rock. Systematic logging of boreholes with a variety of geophysical techniques, including gamma-ray, self-potential, resistivity, and other surveys, is a standard practice in uranium exploration. Modern exploration procedures also include detailed geological mapping, geochemical surveys, and analysis of borehole cuttings and cores in the field and laboratory. The principal States in which uraniumbearing ores have been mined, primarily for their uranium content, are Arizona, Colorado, Nebraska, New Mexico, South Dakota, Texas, Utah, Washington, and Wyoming. Both openpit and under-ground mining methods can be used to produce uranium ores from the ground; these methods are referred to as "conventional" mining. In addition, significant amounts of uranium concentrate are produced by "nonconventional" methods such as solution mining (in situ leaching), and recovery as a byproduct of phosphate, copper, and beryllium production.

At uranium mills, usually located near conventional mines, uranium is extracted from ores by chemical leaching to obtain uranium concentrate. The concentrate from mills, in situ leach plants (including slumy), and byproduct recovery is shipped to conversion facilities, where it is used in the production of uranium hexafluoride $\left(\mathrm{UF}_{6}\right)$.

Uranium hexafluoride is the feed material for the uranium enrichment process. Currently there are two types of enrichment processes used commercially: gaseous diffusion and centrifuge. In the gaseous diffusion process used in the United States, gaseous $\mathrm{UF}_{6}$ is passed through a series, or cascade, of porous membrane filters. The $\mathrm{UF}_{6}$ contains the uranium isotopes $U^{233}$ ( 0.7 percent), which is naturally fissionable, and $U^{238}$ (99.3 percent), which is not naturally fissionable. In the filtering process, $\mathrm{UF}_{6}$ molecules containing the $U^{235}$ isotope diffuse through the filters more readily than molecules containing the $U^{238}$ isotope. Repeated several times in series, the diffusion process eventually results in two product streams of $\mathrm{UF}_{6}$. Compared with the original feed material, one product stream is relatively enriched in the isotope $U^{233}$, and the other is relatively depleted in $U^{233}$.

In the enrichment process for commercial nuclear fuel, the concentration of $\mathrm{U}^{235}$ is increased from the naturally occurring 0.7 percent to about 3.5 percent. Enrichment is necessary for uranium used as fuel in light-water reactors, because the amount of fissile $\mathrm{U}^{235}$ in natural uranium is too low to sustain a nuclear chain reaction in those reactors. Uranium used as fuel for heavy-water reactors does not require enrichment.

At the fuel fabrication plant, the enriched $U_{6}$ is converted to uranium dioxide $\left(\mathrm{UO}_{2}\right)$. The uranium dioxide is compressed into solid, cylinder-shaped pellets that are placed in hollow rods made of a zirconium stainlesssteel alloy. These rods are grouped to form fuel-rod assemblies, which, in various configurations, are shipped to nuclear power plants for use as nuclear reactor fuel.

\section{Estimation of Reserves and Potential Resources}

This section discusses the methodologies used to estimate the U.S. uranium resources. Three classes of resources are estimated: Reserves, Estimated Additional Resources (EAR), and Speculative Resources (SR). EAR and SR categories have been updated using information provided by the U.S. Geological Survey.

A diagram showing a comparison of nomenclatural schemes used by the EIA and predecessor agencies for reporting estimates of U.S. uranium resources since 1974 is provided in Figure B1.

\section{Appraisal of Potential Resources}

The appraisal of the Nation's potential resources of uranium, which comprise the EAR and SR categories, is based on extensive data collected under the uranium procurement and resource appraisal programs of DOE, its predecessor agencies, and the USGS. These data include: analyses of company-supplied gamma-ray logs of drill holes; chemical assays of core samples; data from geochemical surveys of groundwater and stream water and sediment; aerial radiometric surveys; limited selective drilling to fill voids in subsurface information; and extensive geological studies of field areas throughout the United States.

An estimate of the uranium endowment is calculated for each geologically favorable setting delineated. The estimate is derived through evaluation and integration of data from field studies, as well as from mathematical and geological models of known uranium deposits (control areas). The uranium endowment, for a given geographical area under study, is an estimate of the quantity of all uranium-bearing material with a grade of at least 0.01 percent $\mathrm{U}_{3} \mathrm{O}_{8}$ postulated to occur in that setting. This estimate is made before any consideration is given to the economics of exploration and exploi- 
tation. It therefore includes undiscovered resources (EAR and SR), as well as associated additional material at or above the 0.01 percent cut-off grade within the area for which the estimate is made.

In the estimation of potential resources, economic factors for discovering, mining, and milling the undiscovered deposits in the favorable area are determined, and the costs are computed considering information about depposit location, depth, and other parameters. Computerbased models are used to determine operating costs for mining, hauling, milling, severance and ad valorem taxes, royalty, and capital costs for land acquisition, exploration, development, mining, and milling. All costs are forward costs: that is, costs that have not beenincurred. The cost factors are used to calculate average and cut-off grades that are expected to be economic for the $\$ 30-, \$ 50-$, and $\$ 100$-per-pound $\mathrm{U}_{3} \mathrm{O}_{8}$ category in each favorable area. A grade-tonnage relationship, usually derived from the selected control area, is also needed to calculate economic potential resources. The grade-tonnage relationship is used to define a probability distribution for various grades, which in turn is used to develop a probability statement about the quantity of resources likely to meet or exceed the grade criteria.

\section{Figure B1. Comparicon of Hiotorical and Current U.S. and NEAMAEA Classification Nomenclatures for Uranlum Rosources}
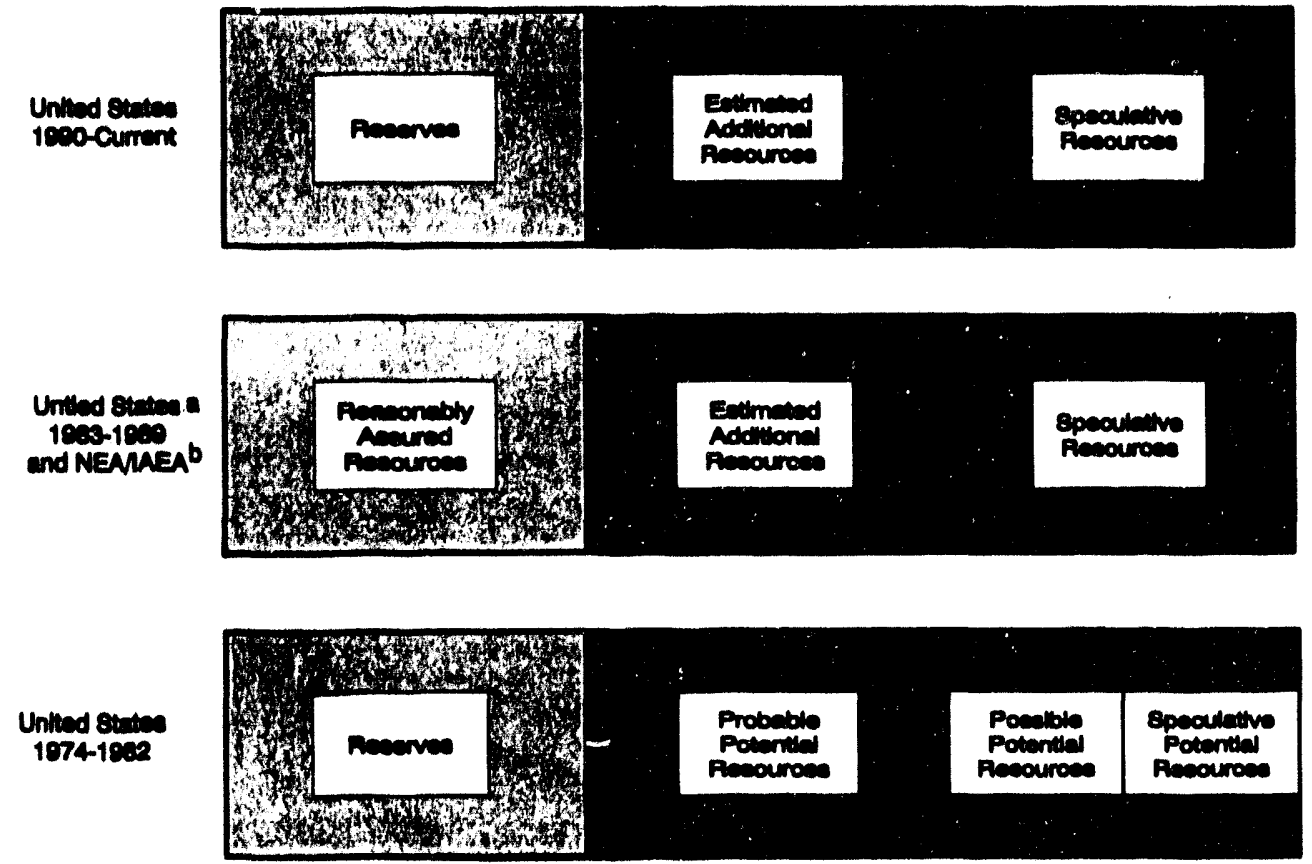

\footnotetext{
'Thls nomenclature was adopled in 1883 by the U.S. Department of Energy and was pattomed aftor the Nuclear Energy Agoncy/intemational Atomle Eneroy Agency Btandard.

The claseilications shown for the United 8 tates pritor to and aftor 1893 and the NEAMAEA are not etrictly comparable, because the criteria used in the individual uyetems are not identical. Preclee correlations are not poselblo, particularty for the less assured resources. Nonotheless, based on the princtpal crtierion of geological aseurance of exiatence, this figure presents a reasonable approximation of uranlum resources claselification comparablity.

WNEMAEA: Nuolear Energy Agency/ntemational Alomic Energy Agoncy.

Note: The NEMAEA separates the Estimated Additional Resources (EAP) into Categorles I and II based primarty on geologloul Inlerenco. Categorles I and II of EAP ine not utilized for eetimates of resources in the United States.

Source: Propared by the Enoroy Information Adminiatration, Office of Coal, Nuclear, Electrle and Ahemate Fuele.
} 
Estimates of Potontial Uranlum Resources, 1965 Through 1973

Prior to 1974, estimates of undiscovered uranium resources made by the U.S. Department of Energy (DOE) were assigned to a single resource class, potential uranium resources. The estimates were made for geologically favorable settings in the western United States, primarily in and adjacent to established uranium mining districts, by using the principles of geological analogy to compare geological characteristics favorable for the occurrence of uranium deposits between a "favorable" area and a similar area with known deposits. The methodology yielded point estimates that lacked associated probability distributions. The estimates of potential uranium resources made for 1965 through 1973 are shown in Table B1.

\section{Potentlal Uranlum Resources, 1974 - 1993}

From January 1974 through September 1983, the Atomic Energy Commission (AEC), the Energy Research and Development Administration (ERDA), and the DOE conducted the National Uranium Resource Evaluation (NURE) program to appraise the uranium resources (including uranium reserves) in favorable geological settings throughout the United States. Estimates of potential resources made during these years were reported for three resource classes to aid in describing thereliabil- ities of potential resources across the wide variety of geological environments investigated during the nationwide program. The three classes of resources used during the NURE program were Probable Potential, Possible Potential, and Speculative Potential Resources. The NURE program was terminated in 1983.

\section{Support from the U.S. Goologleal Survey}

In accordance with a Memorandum of Understanding (MOU) signed in 1984 between the EIA and the U.S. Geological Survey (USGS) of the U.S. Department of the Interior, the USGS provides support for the annual assessment of the Nation's uranium endowment and its undiscovered uranium resources. Through its ongoing geological programs, the USGS conducts studies of uranium districts and favorable geological environments in selected localities where, because of the availability of new scientific knowledge or industry-developed information relating to uranium resources, opportunities exist for updating the National uranium resource data base, the Uranium Resources Assessment Data (URAD) System, first developed under the NURE program. In this manner, the USGS is continuing the assessment of the Nation's uranium endowment and undiscovered uranium resources begun under the DOE's uranium resource appraisal program. The methodology used by

Table B1. Potentlal U.S. Uranium Resources at the End of the Year, 1985-1973 (Million Pounds $\mathrm{U}_{2} \mathrm{O}_{8}$ )

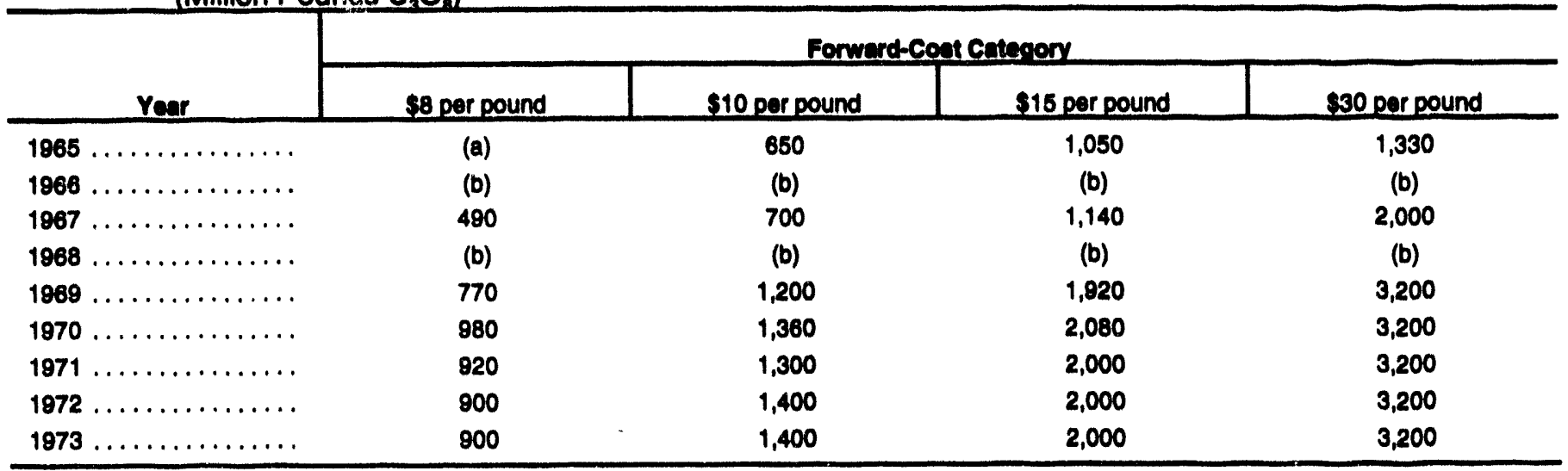

Not estimated at this fonward cost.

'No estimates were made for the end of years 1986 and 1968.

Note: Potential resources at forwand costs above $\$ 30$ per pound $U_{3} O$, were not estimated prior to 1977.

Source: U.S. Department of Energy, Grand Junction Projects Office, Statistical Datia of th- Uranlum Industry (January 1983). 
the USGS to develop the U.S. uranium endowment estimates is described in USGS Circular 994 (1987). ${ }^{5}$

In 1989, the EIA's estimate of potential resources reported for the Colorado Plateau region incorporated for the first time values for uranium endowment supplied by the USGS for deposits associated with the solution-collapse, breccia-pipe environment common in the northern Arizona area. The USGS endowment estimates were used in the EIA cost model, along with endowment estimates for other localities to develop estimates of U.S. potential resources.

\section{Uranium Endowment by Resource Region}

The distribution of mean values of uranium endowment estimates provided by the USGS for U.S. resource regions for 1993 is shown in Table B2. The distribution of endowment values for all regions are unchanged from 1992 values. These endowment values represent the aggregate totals across all favorable localities within each region of the estimated uranium at a grade of 0.01 percent $\mathrm{U}_{3} \mathrm{O}_{8}$ and higher grades. Uranium resource regions are defined by geologic and physiographic characteristics and the regions are shown in Figure B2.

\section{Potential Uranium Resources for 1993, EAR and SR}

Annual estimates of U.S. potential uranium resonrces as EAR and SR are prepared from the uranium endowment data. These estimates consist of the portions of the endowment for over 700 favorable localities that could be recoverable at selected forward costs of production based on economic evaluation of anticipated operating and cap-

Table B2. U.S. Uranium Endowment by Resource Region, 1993 (Million Pounds $\mathrm{U}_{2} \mathrm{O}_{\Omega}$ )

\begin{tabular}{|c|c|c|}
\hline Recource Reqlon & $\begin{array}{l}\text { Endowmont Assoclated with } \\
\text { Eetimated Additional Resourcesa }\end{array}$ & $\begin{array}{l}\text { Endowment Aseociated with } \\
\text { Speculative Resources" }\end{array}$ \\
\hline Colorado Plateau $\ldots \ldots \ldots \ldots \ldots \ldots \ldots \ldots \ldots \ldots$ & 3,950 & 2,430 \\
\hline Wyoming Basins $\ldots \ldots \ldots \ldots \ldots \ldots \ldots \ldots \ldots \ldots \ldots$ & 1,990 & 450 \\
\hline Coastal Plain $\ldots \ldots \ldots \ldots \ldots \ldots \ldots \ldots \ldots \ldots \ldots$ & 910 & 410 \\
\hline Northem Rockies $\ldots \ldots \ldots \ldots \ldots \ldots \ldots \ldots \ldots \ldots$ & 680 & 3,940 \\
\hline Colorado and Southem Rockles $\ldots \ldots \ldots \ldots \ldots \ldots \ldots$ & 320 & 360 \\
\hline Great Plains $\ldots \ldots \ldots \ldots \ldots \ldots \ldots \ldots \ldots \ldots \ldots \ldots \ldots \ldots \ldots \ldots \ldots \ldots$ & 310 & 950 \\
\hline Basin and Range ... & 1,420 & 1,080 \\
\hline Central Lowiands . . . . . . . . . . . . . . . . . . . . . . . & (b) & 280 \\
\hline Appalachian Highlands & 120 & 1,140 \\
\hline Other Regions ${ }^{b} \ldots \ldots \ldots \ldots \ldots \ldots \ldots \ldots \ldots \ldots \ldots$ & 50 & 120 \\
\hline Total .......... & 9,750 & 11,160 \\
\hline
\end{tabular}

Values shown are the mean values for the distribution of estimates for each forward-cost category, rounded to the nearest 10 million pounds $U_{2}, \mathrm{O}_{\mathrm{s}}$.

bNo uranlum endowment in the Eetimated Additional Resources category is estimated for this resource region.

Includes endowment associated with Estimated Addtional Resounces for Pac'sc Coast negion and Alaska and endowment associated with Speculative Resources for Columbla Platoau, Pacific Coset, and Southem Canadian Shlold regions and Alaska.

Notes: Estimates of uranlum that could be recovered as a byproduct of other commodities are not included. Totals may not equal sum of components because of independent rounding.

Sources: Estimates are besed on urantum resources data developed under the DOE Netional Uranilum Resources Evaluation (NURE) program using mothodology deecribed in An Assessment Report on Uranlum in the Unted States of America (October 1980), in U.S. Department of Energy Uranium Industry Seminar (October 1980), and under the USGS Uranium Resource Assessment project using the methodology described in Uranilum Resources Assessment by the Goological Survoy: Methodology and Plan to Update the National Resource Base, U.S. Geological Survey Circular 924 (1887).

'W.I. Finch and R.B. McCammon, "Uranium Resource Assessment by the Geological Suroey: Methodology and Plan to Update the National Resource Base," U.S. Geological Survey Circular 944 (Denver, Colorado, 1987), p. 31. 


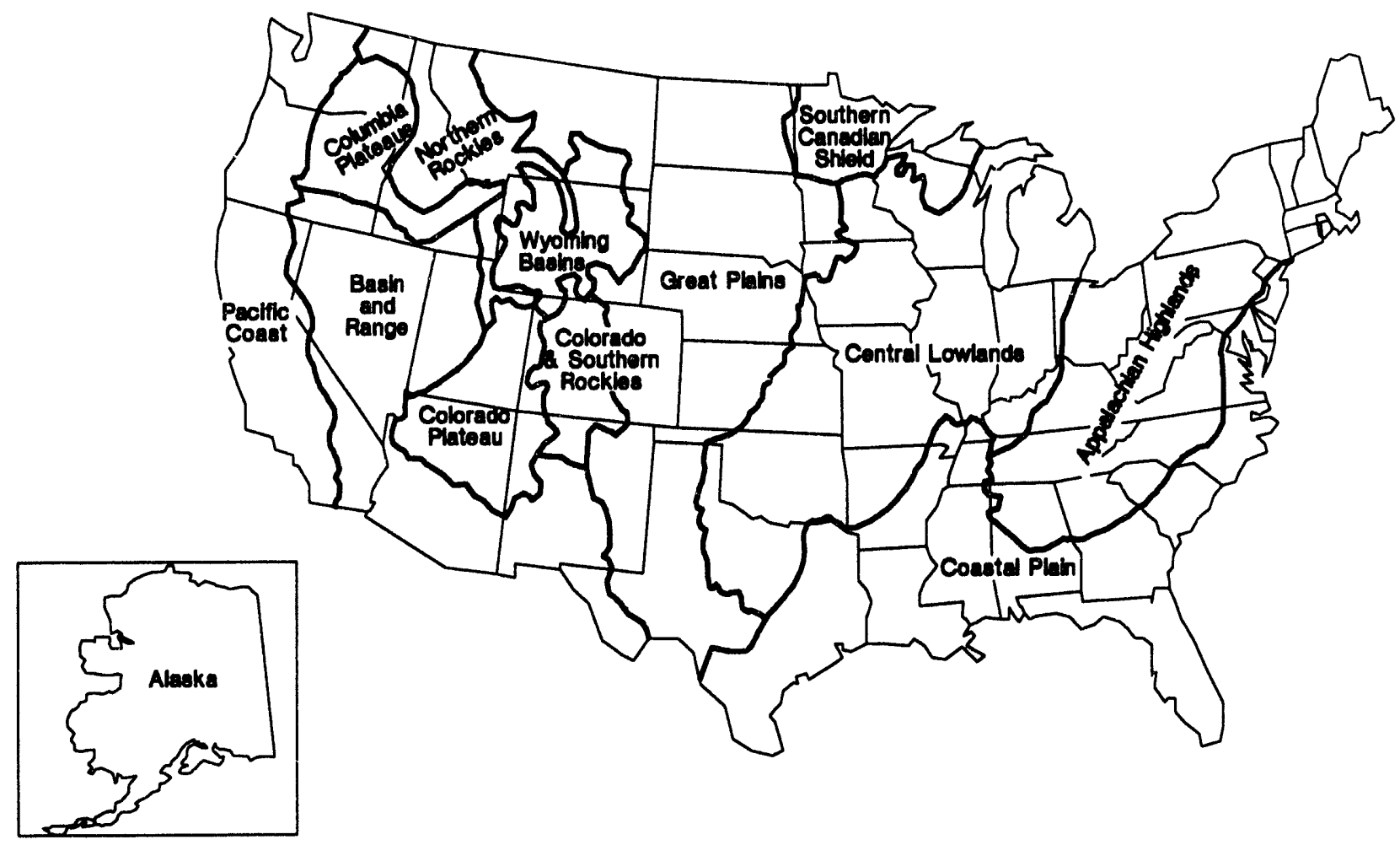

Source: U.S. Department of Enorgy, An Assessment Report on Uranium in the Untied States of America, GVO-111(80) (Grand Junction, Colorado, October 1980).

ital costs, cutoff grade, minimum mining grade, and other factors.

Estimates of U.S. EAR and SR were updated for 1993 by using revised economic index valies (current to December 1993) in the URAD System's cost model, the extensive data on potential uranium resources that were compiled during the NURE program, and subsequent data developed by the USGS. The economic indexes are the Wholesale Price Index-Industrial Commodities (WPI), the Marshall and Swift Mining-Milling Equipment Cost Index (MSI), and the Chemical Engineering Plant Cost Index (CEP). For 1990, the URAD System cost model was updated to raise the pre-set threshold value for the average-grade cutoff to reflect the higher range of average grades encountered in deposits in the breccia-pipe environment in northern Arizona. In 1991, the threshold value for the average grade cutoff was removed altogether. This was done in order to reflect more accurately the entire range in grades of the uranium inventory represented by the grade-tonnage curves across all control areas. This change resulted in overall increases in the estimates for the total EAR and SR cost categories with progressively smaller increases with each higher cost category. Estimates for years prior to 1990 would also be affected by this change; however, the changes in the values are not significant and therefore have not been made. Estimates of potential resources in the EAR and SR classes for 1974 through 1993 are shown in Table B3.

For 1993 , the mean values for the $\$ 30-, \$ 50-$, and $\$ 100$ per-pound $\mathrm{U}_{3} \mathrm{O}_{8}$ forward-cost categories of EAR and SR declined slightly when compared with the EAR and SR values for 1992. These differences are not apparent in Table B3, because the values of EAR and SR are rounded to the nearest 100 million pounds $\mathrm{U}_{3} \mathrm{O}_{8}$ in 1992.

\section{Distribution of EAR and SR by Resource Reglon}

The mean values of EAR and SR are summarized for principal resource regions and forward-cost categories 
Table B3. U.S. Potential Uranium Resources by Forward-Cost Category and Resource Class, 19741993

(Million Pounds $\mathrm{U}_{3} \mathrm{O}_{8}$ )

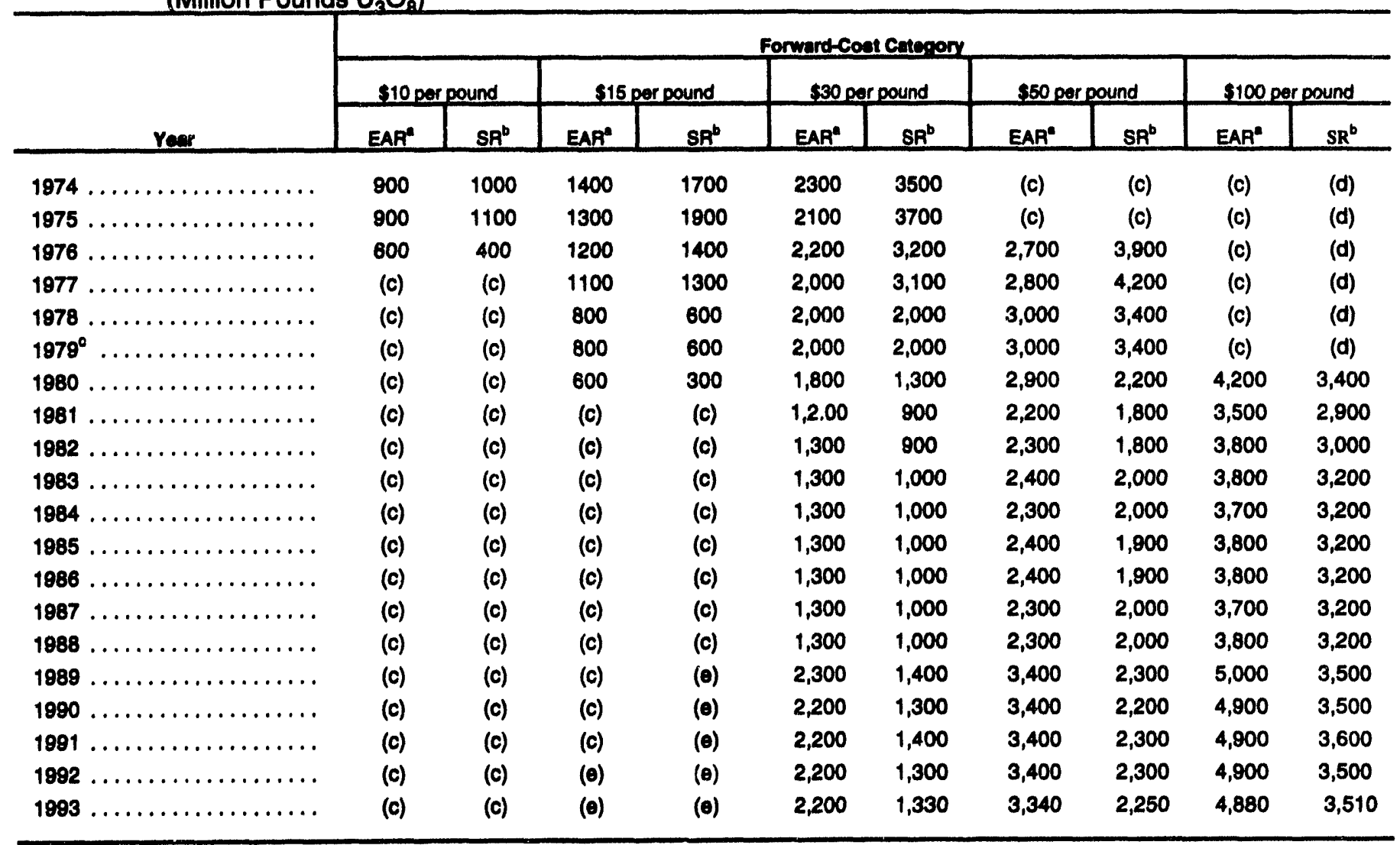

EAR = Estimated Additional Recources

'SR = Speculative Resources

"Not estimated for the indicated forward-cost category.

No new estimates were released for the end of 1979, since the NURE program was to publlah estimates of potential resources by October 1880.

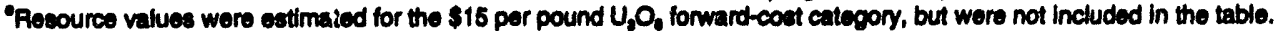

Notes: Values shown are the mean values for the dietribution of extimates for each fonward-coet category: 1974-1982- rounded to the nearest 100 million pounds $U_{3} \mathrm{O}_{\mathrm{g}}$. 1983- rounded to the nearest 10 million pounds $U_{2} O_{2}$. Estimates of urenium that could be recovered as a byproduct of other commodities are not included. Resource values in fonward-cost categories are cumulative: that is, the quantity at each level of forward cost includes all resources at the lower cost in that category.

Sources: 1974-1892-U.S. Department of Energy, Grand Junction Projects Ofilce, Statiatical Data of the Uranium Industry (January 1883). 18e3-18e8-Estimates based on uranium rescurces data developed under the DOE National Uranlum Resource Evaluation (NURE) program, 1874-1883, using mothodology described in An Assesement Report on Uranlum in the United States of Amertan (October 1890) in U.S. Department of Energy, Uranium Industry Seminar (October 1880); and under

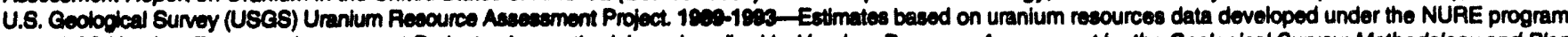
and USCS Urantum Resource Assesement Project using methodology described in Uranium Rosounce Assessment by the Geologlcal Survey: Mothodology and Plan to Update the National Resource Base, U.8. Geological Survey Circular 984 (1887).

in Table B4. Resource regions are shown on Figure B2. Declines occurred in 1993 in the \$30-per-pound $\mathrm{U}_{3} \mathrm{O}_{8}$ EAR values for the Colorado Plateau and in the SR values for the Colorado Plateau, and Other Regions. Declines also are shown for several regions at the higher forward-cost categories. The declines are a result of assumed higher economic indexes due to escalation of costs in the U.S. economy.

\section{Distribution of EAR and SR by Land Status}

The distribution by land status of mean values for $\$ 50$ per-pound EAR and SR at the end of 1993 is shown in Table B5. Estimates for the quantities of EAR show minor changes compared with 1992 . The full extent of these small changes is not apparent in the values shown on Table B5, because those values are rounded to the nearest 10 million pounds of $\mathrm{U}_{3} \mathrm{O}_{8}$. 
Table B4. U.S. Potential Uranlum Resources by Forward-Cost Category and Resource Reglon, 1993 (Million Pounds $\mathrm{U}_{3} \mathrm{O}_{8}$ )

\begin{tabular}{|c|c|c|c|c|c|c|}
\hline Resource Rerlon & \multicolumn{2}{|c|}{$\$ 30$ per pound } & \multicolumn{2}{|c|}{$\$ 50$ per pound } & \multicolumn{2}{|c|}{$\$ 100$ per pound } \\
\hline Colorado Plateau $\ldots \ldots \ldots \ldots \ldots \ldots \ldots \ldots \ldots$ & 1,350 & 480 & 1,810 & 780 & 2,550 & 1,220 \\
\hline Wyoming Basins $\ldots \ldots \ldots \ldots \ldots \ldots \ldots \ldots$ & 160 & 90 & 350 & 160 & 670 & 250 \\
\hline Colorado and Southem Rockles . ............... & 140 & 90 & 180 & 140 & 220 & 190 \\
\hline Badn and Range $\ldots \ldots \ldots \ldots \ldots \ldots \ldots \ldots \ldots$ & 50 & 100 & 160 & 170 & 400 & 320 \\
\hline Other Reglons ${ }^{\circ} \ldots \ldots \ldots \ldots \ldots \ldots \ldots \ldots \ldots \ldots$ & 110 & 330 & 180 & 620 & 270 & 1,000 \\
\hline Total ......... & 2,200 & 1,330 & 3,340 & 2,250 & 4,880 & 3,510 \\
\hline
\end{tabular}

EAR = Estimated Additional Resources

'BR = Speculativo Resources

Inctudes Appalachlan Highlands, Grout Plains, Pacific Coset and Slerra Nevada, Contral Lomlands, and Columbla Plateau reglons and Alaska.

Notes: Values shown are the mean values for the distribution of estimates for each forward-cost category, rounded to the nearest 10 million pounds U3OB. Estimates of uranium that could be recovered as a byproduct of other commodites are not included. Resource values in forward-coet categorles are cumulative: that is, the quantity at each level of forward cost includes all resources at the lower cost in that category. Totals may not equal sum of components because of independent rounding.

Sources: Prepared by the Energy Information Administration, Office of Coal, Nuclear, Electric and Attemate Fuels, based on uranium resources data developed under DOE National Urantum Resourco Evaluation (NURE) program and the USGS Urantum Resource Asesesement project, ueing methodology described in Uranlum Resource Asecesement by the Geological Survey: Methodology and Plan to Update the National Resource Base, U.S. Geological Survey Cireular 894 (1987).

Decreases in the quantities over those for 1992 are shown for EAR for Bureau of Land Management Land, Indian Lands, and Private Fee Lands and for SR for Private Fee Lands.

\section{U.S. Uranium Reserves}

Uranium reserves are the estimated quantities of uranium that occur in known deposits of such grade, quantity, configuration, and depth that they can be recovered at or below a specified cost with state-of-the-art mining and processing technology. Estimated reserves are based on direct radiometric and chemical measurements in drill holes and other types of sampling of deposits. Mineral grades and thickness, spatial relationships, depths below the surface, mining and reclamation methods, distances to milling facilities, and amenability of ores to processing are considered in the evaluation. The amounts of uranium in ore that could be exploited within specified forwardcost levels are estimated according to conventional engineering practices, using available engineering, geologic, and economic data. Uranium reserves estimated by the DOE have been adjusted for mining dilution and mill recovery.
The costs used to categorize uranium resources are forward costs (operating and capital costs) in current (year of estimate) dollars that would be incurred in producing the uranium. The costs indirectly cover power and fuel, labor, materials, royalties, payroll, severance and ad valorem taxes, insurance, and applicable general and administrative costs. Previous expenditures (before the time of the estimate) for such items as property acquisition, exploration, mine development, and mill construction are excluded. Also excluded are income taxes, profit, and the cost of money. The forward-cost categories are independent of the market price at which the uranium might be sold. In estimating reserves for developed properties, land acquisition and exploration costs commonly are past expenditures and thus are excluded from the cost estimates.

\section{Procedure for Eatimating Reserves, 1964-1983}

U.S. uranium reserves from 1964 to 1983 were estimated by the DOE using data voluntarily provided by uranium companies to DOE's Grand Junction Projects Office. Reserves were estimated for each property individually and were based on available data from samples, drill holes, 
Table B5. Estimated Additional Resources (EAR) and Speculative Resources (SR) In the \$50-perPound Forward-Cost Category by Land Status at the End of 1993

\begin{tabular}{|c|c|c|c|c|}
\hline \multirow[b]{2}{*}{ Land Status } & \multicolumn{2}{|c|}{ Eetimated Additional Recources. } & \multicolumn{2}{|c|}{ Speculative Resources } \\
\hline & Million Pounds $\mathrm{U}_{2} \mathrm{O}_{\mathrm{S}}$ & Percent of Total & Million Pounds U,O & $\begin{array}{c}\text { Percent of } \\
\text { Total }\end{array}$ \\
\hline \multicolumn{5}{|l|}{ Public Lands } \\
\hline \multicolumn{5}{|l|}{ Bureau of Land Management } \\
\hline and Forest Service Lands $\ldots \ldots \ldots \ldots \ldots$ & 880 & 28.8 & 480 & 21.2 \\
\hline National Park Service Lands $\ldots \ldots \ldots \ldots \ldots \ldots \ldots$ & 110 & 3.3 & 10 & 0.5 \\
\hline Wildifie Retuges $\ldots \ldots \ldots \ldots \ldots \ldots \ldots \ldots \ldots \ldots \ldots \ldots$ & (a) & (b) & (a) & 0.1 \\
\hline DOE-Administered $\ldots \ldots \ldots \ldots \ldots \ldots \ldots \ldots \ldots \ldots$ & 10 & 0.2 & (a) & (b) \\
\hline 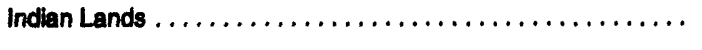 & 450 & 13.6 & 230 & 10.2 \\
\hline$\ldots \ldots+\ldots, \ldots, \ldots, \ldots, \ldots$ & 200 & 5.8 & 160 & 7.2 \\
\hline Total ...... & 3,340 & 100.0 & 2,260 & 100.0 \\
\hline
\end{tabular}

\footnotetext{
Value is less than 5 million pounds $U_{9} O_{0}$.

Value is less than 0.05 percont.

includes rallroad lands and patented claims.

Notes: Values shown are the mean values for the distribution of estlmates of EAR and SR, rounded to the nearest 10 million pounds $\mathrm{U}_{3} \mathrm{O}_{\mathrm{s}}$. Estimates of uranium that csuld be recovered as a byproduct of other commodities are not inctuded. Totals may not equal sum of components because of independent rounding.

Sources: Prepared by the Energy Information Administration, Olifice of Coal, Nuclear, Electric and Altemate Fuels, based on uranlum resources data developed under DOE National Uranium Resource Evaluation (NURE) program and tho USGS Urantum Reeourco Aseesement project, using mothodology described in Uranium Resource Assessment by the Geological Survey: Mothodology and Plan to Update the National Rosounce Base, U.S. Geological Survey Circular 994 (1987).
}

and property maps. The amounts of uranium in ore that could be produced from a property at maximum forward costs of $\$ 15-, \$ 30-, \$ 50-$, and $\$ 100$-per-pound $\mathrm{U}_{3} \mathrm{O}_{8}$ were estimated by the general procedure outlined below. This procedure was applied to the estimates of reserves to be recovered by openpit, underground, and in situ leaching operations.

1. The cut-off grade was determined to define the lowest grade (in percent $\mathrm{U}_{3} \mathrm{O}_{8}$ ) of material that could be mined from a property at a given thickness, where the total operating cost per pound of recoverable $\mathrm{U}_{3} \mathrm{O}_{8}$ in such material would be equal to the chosen cost (\$15-, \$30-, \$50-, or $\$ 100-$ ) per-pound. The cutoff grade was determined by the following formula:

$$
C G={ }^{\left(M_{n}+H+R+M_{1}\right)(100)}
$$

where:

$$
(C C)\left(M_{r}\right)(2,000)
$$

$$
\begin{aligned}
C G & =\text { cut-off grade in percent, } \\
M_{n} & =\text { cost of mining per ton of ore, } \\
H & =\text { cost of hauling per ton of ore, }
\end{aligned}
$$

$$
\begin{aligned}
R & =\text { royalty costs per ton of ore, } \\
M_{l} & =\text { cost of milling per ton of ore, } \\
C C & =\text { chosen cost per pound } \mathrm{U}_{3} \mathrm{O}_{8}, \text { and } \\
M_{r} & =\text { mill recovery rate (in percent) }
\end{aligned}
$$

2. The quantity of mineralized material in the deposit that met or exceeded the cut-off grade and thickness criteria was estimated, in tons of material and average grade adjusted for mining recovery and dilution.

3. All forward operating and capital costs not yet incurred were applied to determine the average cost for mining and processing per pound $\mathrm{U}_{3} \mathrm{O}_{8}$.

4. If the average cost per pound $\mathrm{U}_{3} \mathrm{O}_{8}$ derived in Step 3 was equal to or less than the chosen cost category, the material was assigned to that cost category.

The procedures described above applied to reserves suitable for conventional mining. The quantities of $\mathrm{U}_{3} \mathrm{O}_{8}$ estimated to $t$ recoverable from in situ leaching operations are incl. in reserves totals but were estimated by another methou. situ leaching above a selected minimum thickness were calculated for those properties on which in situ mining was in progress or was planned. The minimum grade-thickness was determined for each 
property, and the reserves were determined by multiplying the estimated amount of $\mathrm{U}_{3} \mathrm{O}_{8}$ by a mining recovery factor

\section{Procedure for Estimating Reserves for 1984 to 1989}

During 1983, the estimation procedure described above was ended. Estimates for the end of 1984 through 1989 were made by adjusting the estimates made for the end of 1983. For this period, additions to reserves were made for properties not in the NURE data base. Deletions from reserves were made during the period for properties reported as mined out. Adjustments were also made to account for production, including "erosion" of higher cost reserves caused by the mining of lower cost reserves.

Beginning in 1984, the Energy Information Administration (EIA), through the Form EIA-858, "Uranium Industry Annual Survey," requested that domestic uranium industry companies report their estimates of economic reserves of uranium. Aggregations of U.S. economic reserves quantities were published in the report series Uranium Industry Annual beginning in 1985. Domestic uranium companies also were requested, beginning in 1985, to report estimates of their subeconomic uranium reserves. The estimates of economic and subeconomic reserves were derived by the uranium companies based on analyses of all pertinent data acquired in the exploration and development of individual properties and on cost anticipated for the individual mining operations.

\section{Current Procedure for Estimating Reserves}

Estimates of reserves as of the end of 1990 through 1993 reflect the phasing in of a new approach to estimation now employed by the EIA. The previous procedure in which estimates were made by modifying earlier depositby-deposit estimates made by DOE staff, which was in use since 1984 and is described above, has been phased out. The basic deposit estimates that were being modified are now thought to be too old to serve as a suitable base for making current reserve estimates. Additional changes have taken place affecting the status of the deposits that cannot be reflected in a modification of the estimates based primarily on adjustment for annual production. These include increased knowledge of the deposits from recent exploration and mining, environmental restriction that impact on the ability of the domestic industry to economically produce uranium, the changing status of industry firms, and changes in mining and processing technology.

The new procedure develops current estimates of reserves producible at.selected cost levels using basic information provided by the mining companies. This approach relies on closer cooperation and information exchange with the uranium companies. Direct use of company estimates and information are made to the maximum extent possible. Company reserve estimates are used directly where they conform to EIA definitions and criteria. Modification to company estimates are made as needed to put them in conformity with the EIA standards or use of historical data to develop missing estimates. Where this is not possible independent deposit reserve estimates using methods similar to the 1964-1983 procedure described above are made by EIA staff.

The costs considered for each cost level includes all forward-cost estimates required to develop and produce the uranium that will be recovered in the mining and processing of ores. This includes capital and operating costs incurred from the nominal date of the estimate.

There are three main components to the new approach;

1. Gathering of Information by Questionnaire, Form EIA-858

Form EIA-858 was revised for 1990 to clearly lay out EIA objectives and criteria to encourage full reporting of essential reserve data and related information. In addition, the Form was simplified and clarified. Some items previously requested, such as company estimates of "economic" and "subeconomic" reserves, were eliminated. The responses to the Form provide the basic input from the industry on the status of the properties with uranium resources, exploration and development activities, and the company estimates of reserves under the EIA criteria or under the criteria being used by the companies, together with information on the criteria and procedures used. Review of the information received from the Form provides a basis for determining further action by EIA, in conjunction with historical information held by the EIA concerning company estimation procedures.

\section{Review of Company Procedures}

Building on information provided by companies in the Form EIA-858 provides a basis for determining whether the company's estimates meet EIA criteria without modification. If ELA criteria are not met, followup meetings are held with company staff. In these meetings a detailed discussion of the company criteria and procedures for reserve estimation is held. A clear understanding of company procedures can provide a basis for modifying company estimates to 
make them consistent with EIA criteria. Establishment of such understanding with a company can provide a simplified procedure for the EIA to use in handling data received from the company in the future.

\section{Independent EIA Estimates}

Where a review of company procedures indicates it is not feasible to accept company estimates directly or to modify them to conform to EIA criteria, independent EIA estimates of reserves are made using company-provided basic data. In some cases, independent reserve estimation and analysis are done to establish ore deposit parametric relationships that provide a means to modify company estimates to EIA criteria without complete deposit reevaluation.
Compilation of the estimates for individual uranium properties gathered at the various steps results in a national uranium reserve estimate at various cost categories. Since a complete cycle of review of industry procedures has not been completed, the currently reported estimates do not completely reflect the results of the new procedure. This will take a few more years to complete. The current reserve estimates are based on a combination of EIA-held historical data, company-reported data, and independent reserve estimates. The 1993 estimates of national uranium reserves are based on current knowledge about domestic deposits and on a consistently applied set of estimating criteria. Current and historical estimates of reserves since 1947 are shown in Table B6. The trends in estimated reserves quantities in each forward-cost category are shown in Figure B3 for the period 1964-1993. 
Table B6. U.S. Uranlum Reserves, 1947-1993 (Million Pounds $\mathrm{U}_{3} \mathrm{O}_{\mathrm{s}}$ )

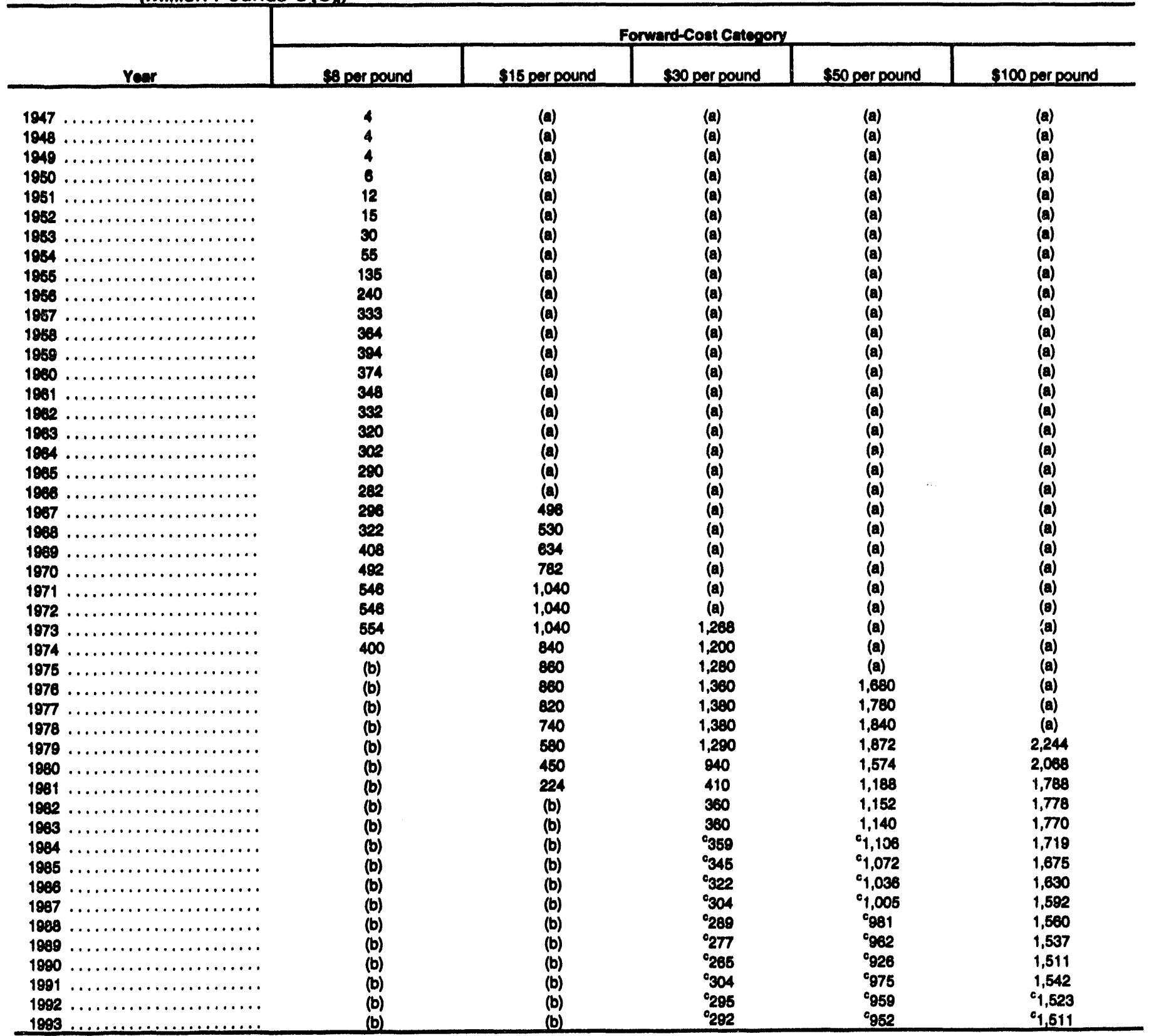

Not estimated for the indicated fonward-coet category.

${ }^{6} F$ For 1974, separate evaluatiens were made of the amounts of reserves that could be explolted at the maximum forward-costs of $\$ 8, \$ 15$, and $\$ 30$ per pound $U_{3}, O_{2}$. Fonvard-cot reserves were not ectmated for the 89 per pound cattecory in 1975, largety because sharp increase in production costs and market prices in the $1972-1975$ period focused attention on the economic availabilly of reserves at higher forward-coet categorles. After January 1, 1975, the $\$ 8$ per pound forward-cost category was

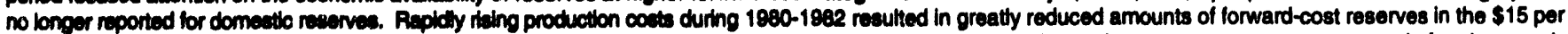
pound catepory in each of those years. The quantthy eetimated for 1981 was insignificant, and this category of forward-cost reserves was not reported after January 1 , 1982. Recerves values in fonward-coet categorles are cumulative; that is, the quanthy at each lovel of forward cost includes all reserves at the lower costs.

Granlum reserves that could be recovered as a byproduct of phoephate and copper mining are not included in these reserves.

Sources: 1947-1935-U.8. Department of Enoroy, Grand Junction Projects Oflice, Statistical Data of the Uranlum Industry (January 1978). 1894-1982-U.S. Department of Energy, Grand Junetion Projects Office, Statietical Data of the Uranium Industry (January 1983). 19e3-19e3-Estimatod by the Energy Information Administration, Office of Coal, Nuclear, Electric and Altemate Fuola, based on U.S. Department of Energy, Grand Junction Projects Office data files and Energy Intormation Adminietration, Form ElA-858, Uranlum Induatry Annual Burvoy" (1984-1993). 
Flgure B3. U.S. Reserves by Cumulative Forward-Cost Categories, 1964-1993

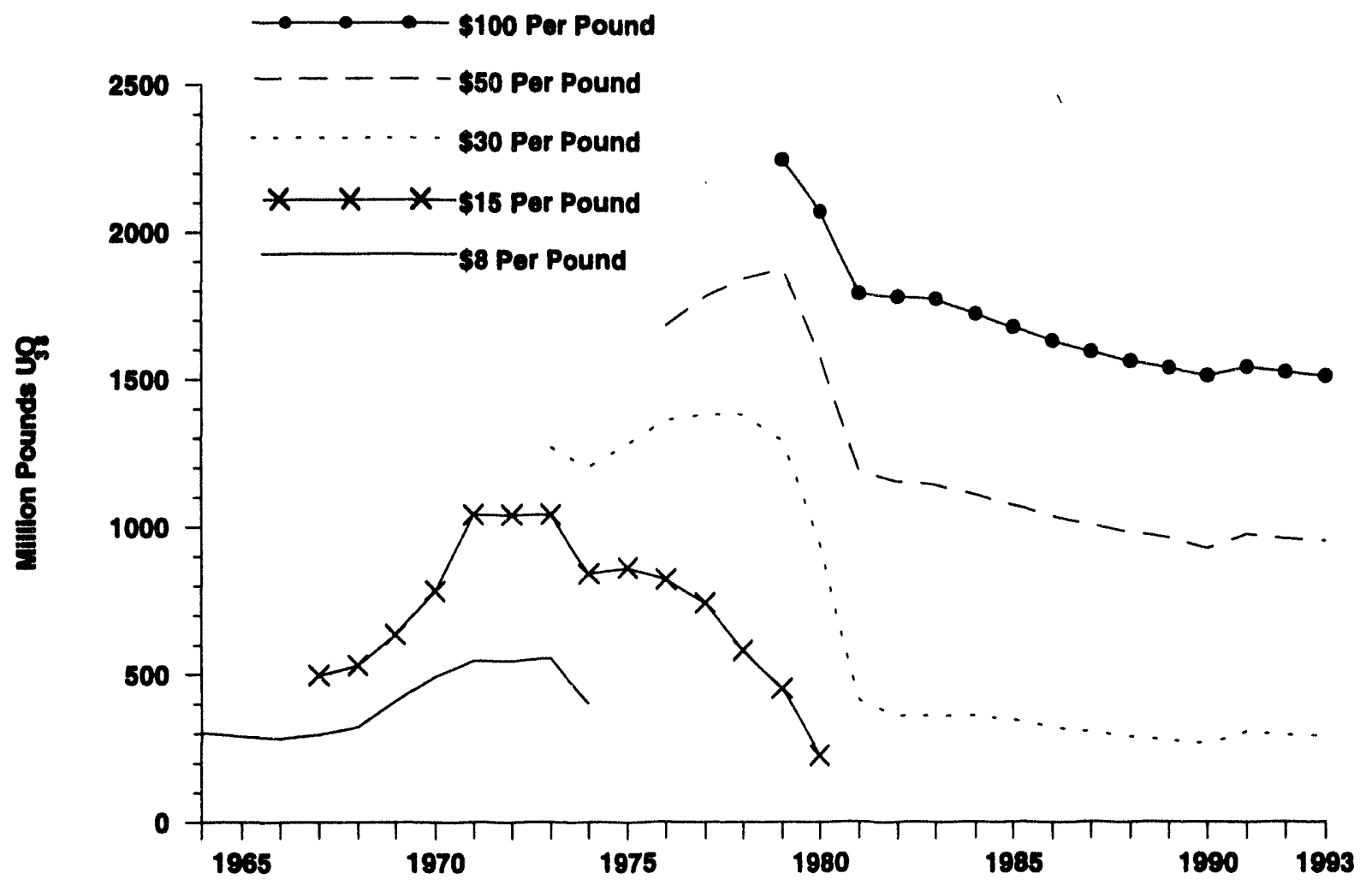

Reserves in the $\$ 8$ per pound fonward-cost category were not reported after January 1, 1976.

"Reserves in the $\$ 15$ per pound forward-cost category were not reported after January 1, 1981.

Notes: Reserves estimated at the end of the year. Estimates of uranium that could be recovered as a byproduct of other commodities are not included. Fonmard-cost catecories of reserves are cumulative within oach year, that is, the quantity at each lovel of forward cost includes all resources at the lower cost levels.

Sources: 1894-1ean-U.8. Department of Energy, Grand Junction Projects Office, Statistical Data of the Uranium Industry (January 1883). 1893-1ees-Estimated by the Energy Information Adminletration, Ofilce of Coel, Nuclear, Electric and Altemate Fuels, based on U.S. Department of Energy, Grand Junction Projects Office data files and Energy Information Adminietration, Form EiA-658, "Uranium Industry Annual Surver" (1984-1993). 


\title{
Appendix C
}

\author{
Respondents to \\ the Uranium \\ Industry Annual \\ Survey
}

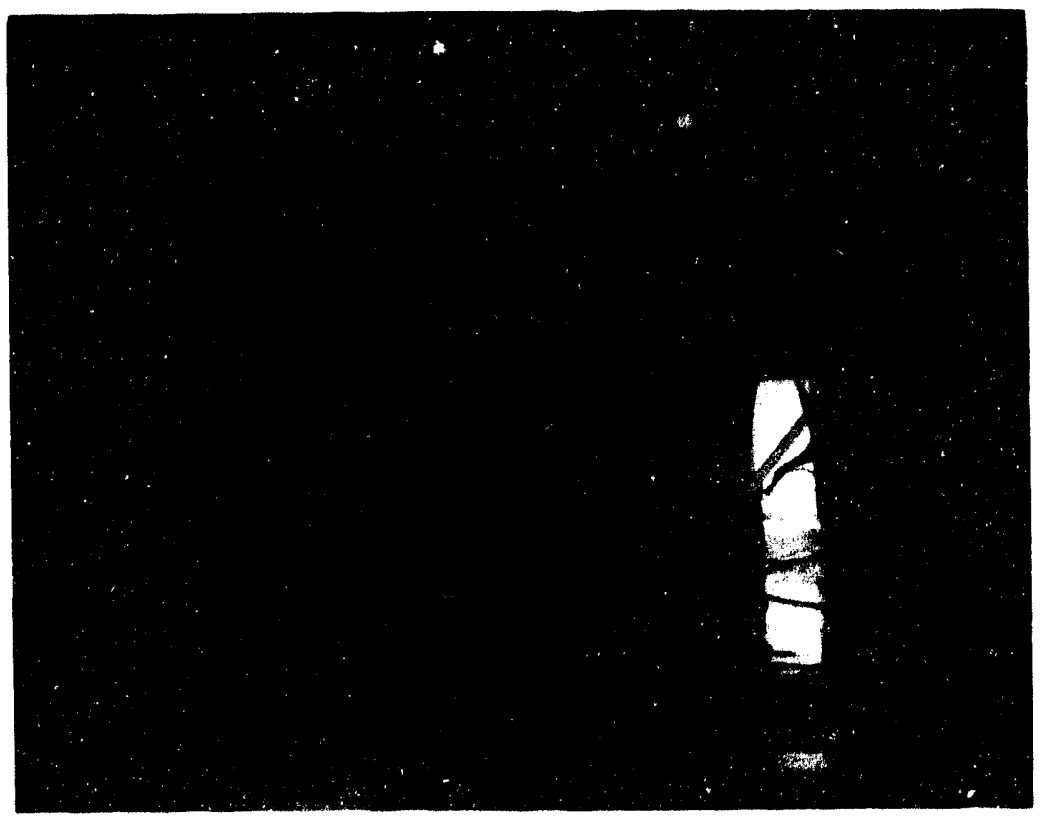

The fitter-press equipment (beckground) is used to procuce high-quality yellowcake $\left(U_{3} O_{\mathcal{J}}\right.$. After bods of resin beads in lon oxchango tanks have become saturatsod whth urantum-boaring anions, washing of the bods with a solvent yiolds a relativoly pure and concontratod uranium solution. This solution is then treated to preclpitate ths diseolved uranium. The procipitate is recovered in the filter press and is then dried and propared for shipment as yellowcake. 
Respondents to the Energy Information Administration's (EIA) 1993 Form EIA-858, "Uranium Industry Annual Survey," are listed alphabetically in Table C1. For each respondent, an industry-activity code (or codes) is shown. The activity code (codes) broadly describes the respondent's major industry activity from the Form EIA858 and from publicly available information. Not in- cluded in the listing are respondents that stated that no part of the Form EIA-858 was applicable to their operations as of the end of the survey year.

An explanation for the activity codes is provided in the notes at the end of Table $\mathrm{Cl}$.

\section{Table C1. Respondents to the 1993 Uranlum Industry Annual Survey}

\begin{tabular}{|c|c|c|c|}
\hline Company Name & Industry Activity Code & Company Name & Industry Activity Code ${ }^{\mathrm{a}}$ \\
\hline $\begin{array}{l}\text { Alabama Power Co. (Southern } \\
\text { Nuclear) }\end{array}$ & UTL & Cotter Corporation & UPH,MLG \\
\hline Albuquerque Uranium Corporation & UPH, BRO & Cycle Resources Investment Corp. & BRO \\
\hline Allied-Signal, Inc. (ConverDyn) & CON & Cyprus Mines Corporation & UPH \\
\hline American Blectric Power Svc. Corp. & UTL & Dave Blake Mining Company & UPH \\
\hline American Nuclear Corporation & UPH & Dawn Mining Company & UPH,MLG \\
\hline Andrews Mining Company & UPH & $\begin{array}{l}\text { Department of Energy, Office of Ura- } \\
\text { nium Programs }\end{array}$ & ENR \\
\hline Arizona Public Service Company & UTL & Detroit Edison & UTL \\
\hline Atlas Corporation & UPH & Duke Power Company & UTL \\
\hline B \& W Puel Company & FAB & Duquesne Light Company & UTL \\
\hline B. B. Brooks Company & UPH & Energy Fuels Corporation & UPH,TRA \\
\hline Baltimore Gas and Electric & UTL & Enserch Exploration, Inc. & UPH \\
\hline BGS Mining Company & UPH & Entergy Operations, Inc. & UTL \\
\hline Boston Edison Company & UTL & Everest Exploration, Inc. & UPH, MLG,TRA \\
\hline Cameco U.S. Inc. & UPH & Ferret Exploration Company of NE & UPH, MLG \\
\hline Cargill Fertilizer & UPH & Ferret Exploration Company, Inc & UPH \\
\hline Carolina Power \& Light & UTL & Florida Power Comporition & UTL \\
\hline Centerior Energy Corporation & UTL & Florida Power and Light & UTL \\
\hline Cobb Resources Corporation & UPH & General Electric Company & FAB \\
\hline Cogema, Inc. & BRO & Geomex Minerals, Inc. & UPH \\
\hline Cogema Mining Inc. (Total Minerals) & UPH,MLG & Georgia Power Co. (Southern Nuclear) & UTL \\
\hline Combustion Engineering, Inc. & FAB & GPU Nuclear Corporation & UTL \\
\hline Commonwealth Edison & UTL & Graves and Hudspeth Company & UPH \\
\hline Consolidated Edison Co. of NY, Inc. & UTL & Green Mountain Mining Venture & UPH, MLG \\
\hline Consumers Power Company & UTL & Gulf States Utilities Company & UTL \\
\hline
\end{tabular}


Table C1. Respondente to the 1993 Uranlum Induatry Annual Survey (Continued)

\begin{tabular}{|c|c|c|c|}
\hline Company Name & Industry Activity Code" & Company Name & Industry Activity Code \\
\hline Homestake Mining Company & UPH & PECO Energy Company & UTL \\
\hline Houston Lighting \& Power Co. & UTL & $\begin{array}{l}\text { Pennaylvania Power \& Light } \\
\text { Company }\end{array}$ & UTL \\
\hline IES Utilities, Inc. & UTL & Petrocomics Compeny (CO Texeco)" & UPH \\
\hline Illinois Power Company & UTL & Piateau Resources Limited & UPH, MLO \\
\hline IMC Fertilizer, Inc. & MLG & Portland Ceneral Electric Company & UTL \\
\hline Kennecott Corporation & UPH & Power Resources, Inc. & UPH, MLO \\
\hline Maine Yankee Atomic Power Co. & UTL & Public Service Electric \& Gas & UTL \\
\hline Malapal Resources Company & UPH,MLG & Rajah Ventures, Limited & UPH \\
\hline Marquez Development Corporation & UPH & Ralph Fonter \& Sons & UPH \\
\hline Melvin Staats Company & UPH & Rhone Poulenc, Inc. & Mno \\
\hline Mesa Limited Partnership & UPH & Rio Alsom Mining Corp. & UPH, MLG \\
\hline Mining Unlimited, Inc. & UPH & Rio Grande Resource Corp. & UPH \\
\hline Nebraska Public Power District & Un. & Riverside Public Utility Dept. & UTL \\
\hline New York Power Authority & UTL & RME Partners L. P. & UPH \\
\hline $\begin{array}{l}\text { New York Nuclear Corp. NYNCO } \\
\text { Trading }\end{array}$ & BRO & Rochester Gas \& Electric Corp. & UTL \\
\hline Niagara Mohawk Power Corporation & UTL & Sacramento Municipal Utility Dist. & UTL \\
\hline Noranda Exploration, Inc. & UPH & San Diego Gas and Electric & UTL \\
\hline North Atlantic Energy Service Corp. & UTL & San Rafael Energy, Inc. & UPH \\
\hline Northeast Utilities Service Co. & UTL & Section 2 Joint Venture & UPH \\
\hline Northem States Power Company & UTL & Sheep Mountain Partners & UPH \\
\hline Nose Rock, Inc. & UPH & Siemens Nuclear Power Col poration & FAB \\
\hline Nuclear Fuel Services, Inc. & UPH & Simons Associates & UPH \\
\hline Nuexco Trading Corporation & TRA, BRO & South Carolina Electric \& Gas & UTL \\
\hline Nukem, Inc. - & TRA, BRO & Southem Califomia Edison Company & UTL \\
\hline $\begin{array}{l}\text { Ohio Edison Co. and Pennsylvania } \\
\text { Power Co. }\end{array}$ & UTL & Southern Cross Services, Inc. & BRO \\
\hline Omaha Public Power District & UTL & Taminco, Inc. & UPH \\
\hline Pacific Gas and Electric Company & UTL & Tennessee Valley Authority & UTL \\
\hline PACIFICORP & UPH & Texas Utilities Electric Company & UTL \\
\hline $\begin{array}{l}\text { Pathfinder Mines Corp. (C/O } \\
\text { Cogema) }\end{array}$ & UPH & UG U.S.A., Inc. & UPH, TRA \\
\hline
\end{tabular}




\section{Table C1. Reapondente to the 1993 Uranium Induatry Annual Survey (Continued)}

\begin{tabular}{|c|c|c|c|}
\hline Company Name & Industry Activity Code & Company Name & Industry Activity Code ${ }^{a}$ \\
\hline Umetco Minerals Company & UPH, MLO & Vermont Yankee Nuclear Power Corp. & UTL \\
\hline Union Bloctric Company & UTL & Virginia Electric and Power co. & UTL \\
\hline Untred Nuclear Corporation & UPH & $\begin{array}{l}\text { Washingion Public Power Supply } \\
\text { Syutem }\end{array}$ & UTL \\
\hline United Stutes Enrichment Corporation & ENR & Westem Nuclear, Inc. & UPH \\
\hline Unanerz USA, Inc. & UPH, BRO & Westinghouse Electric Corporation & FAB \\
\hline Uranium Bxchange Company & TRA,BRO & Wisconsin Blectric Power Company & UTL \\
\hline Unanium King Corporation & UPH & Wisconsin Public Service Corp. & UTL \\
\hline Uranium Resources Incorporated & UPH, MLG, TRA & Wold Nuclear Company & UPH \\
\hline USX Corporation & UPH & Wolf Creek Nuclear Operating Corp. & UTL \\
\hline
\end{tabular}

TBRO = Uranium brokerage compeny; CON = Uranium converaion service supplier; BNR = Uranium enrichment service supplier; FAB = Uranium fuel fabrication cervico supplier; $\mathbf{M L G}=$ Uranium milling/processing company (can involve ownerchip of a uranium property); TRA = Uranium trading company; UPH = Uranium property holder (can include activities related to uranium exploration, reserves, and/or mining); UTL = Nuclear electric utility company.

Source: Prepared by the Bnergy Information Administration, Office of Coal, Nuclear, Blectric and Alternate Fuels, based on information reported on the Form EIA-858 "Uranium Industry Annual Survey" (1993). 


\title{
Appendlx D
}

\author{
Form EIA-858: \\ Uranlum Industry \\ Annual Survey
}

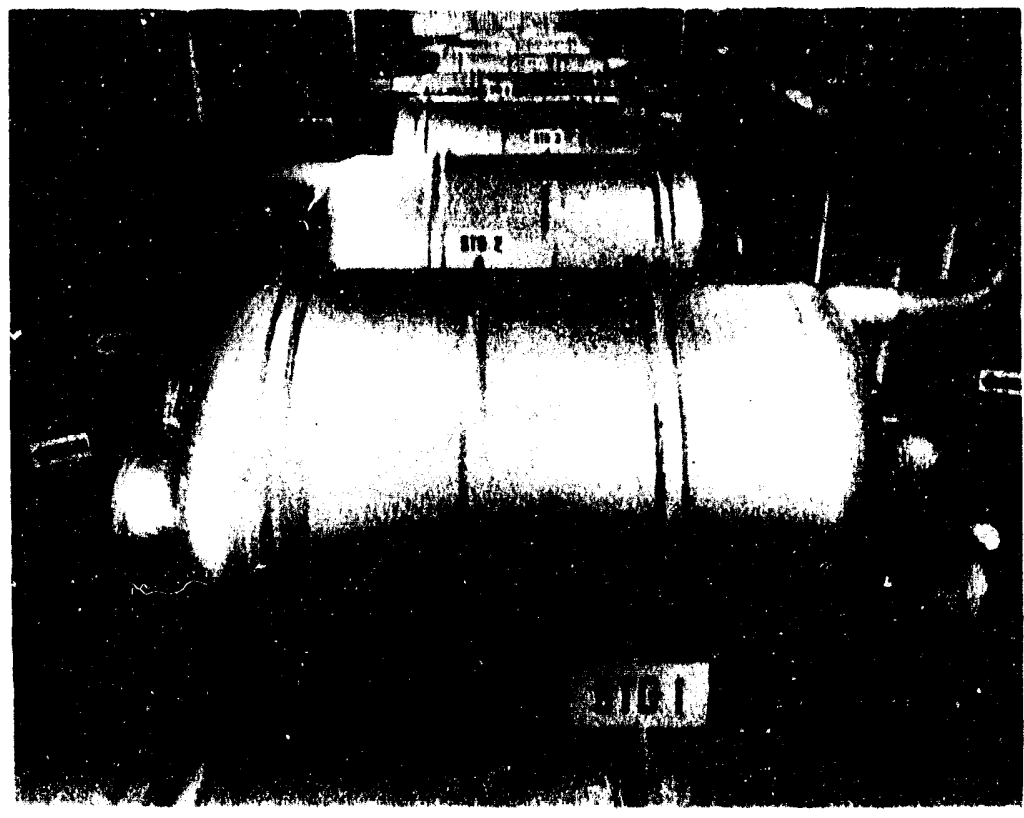

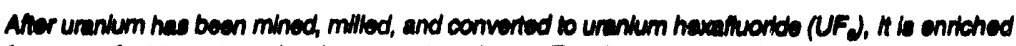

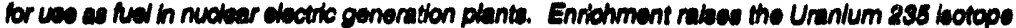

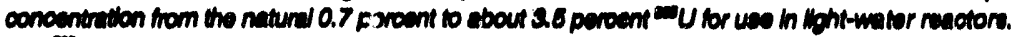

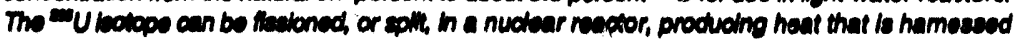

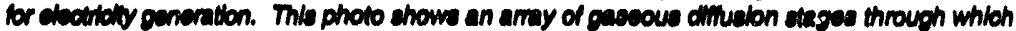
urantum, in gesecous form, lo pumped to sechlove the deetred enritohment lovel. 

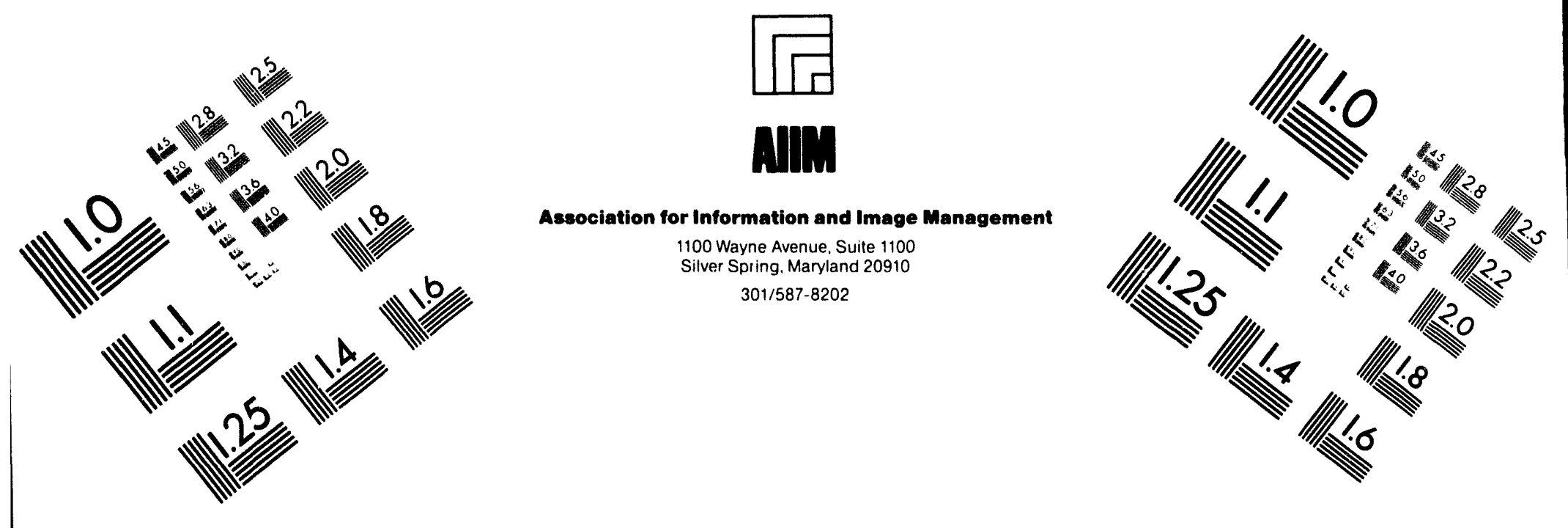

\section{Centimeter}

$\begin{array}{llllllllllllllll}1 & 2 & 3 & 4 & 5 & 6 & 7 & 8 & 9 & 10 & 11 & 12 & 13 & 14 & 15 & \mathrm{~mm}\end{array}$

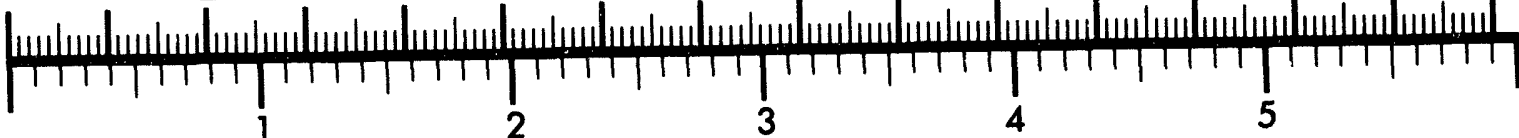
Inches
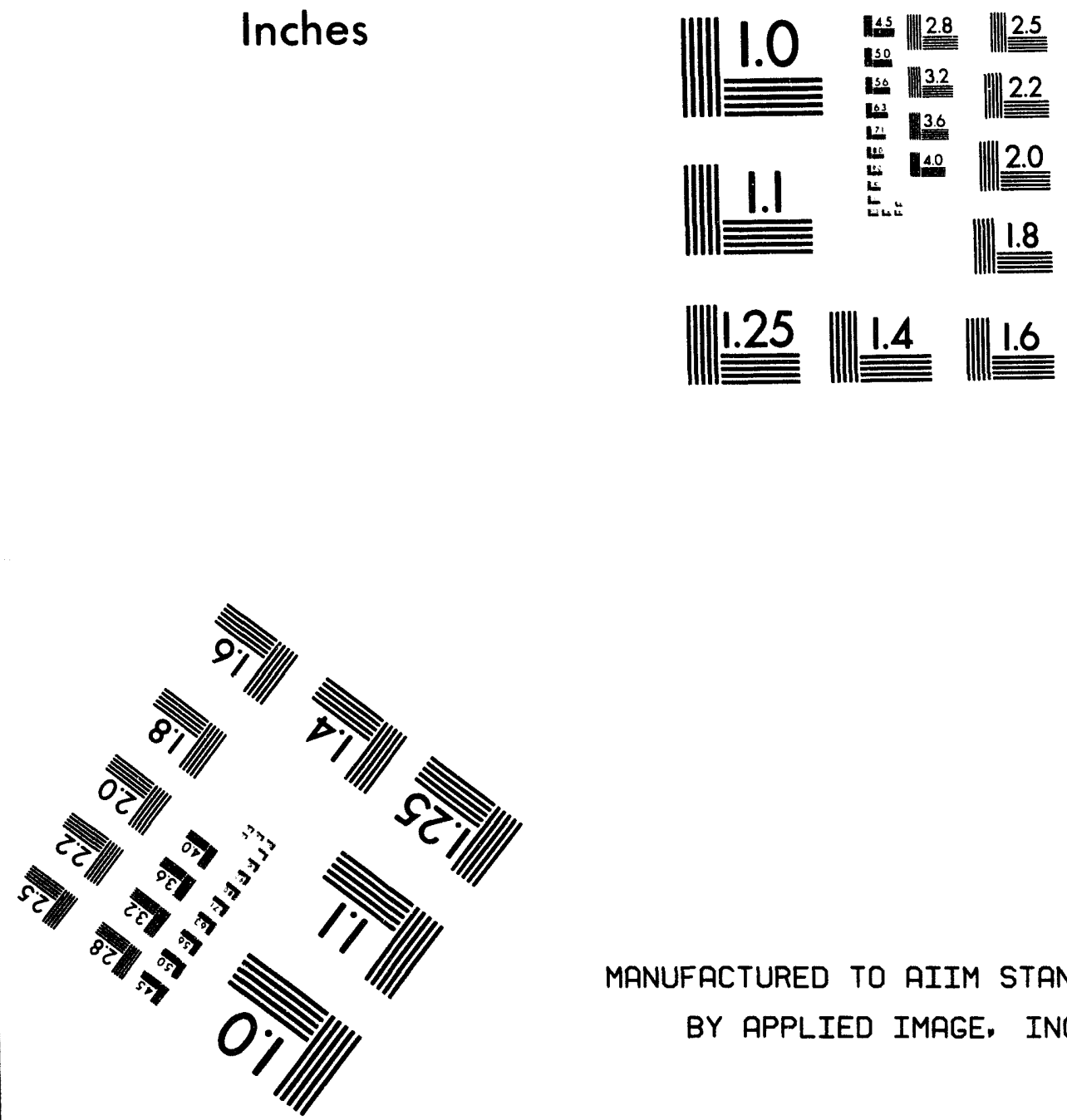

MANUFACTURED TO AIIM STANDARDS BY APPLIED IMAGE, INC.

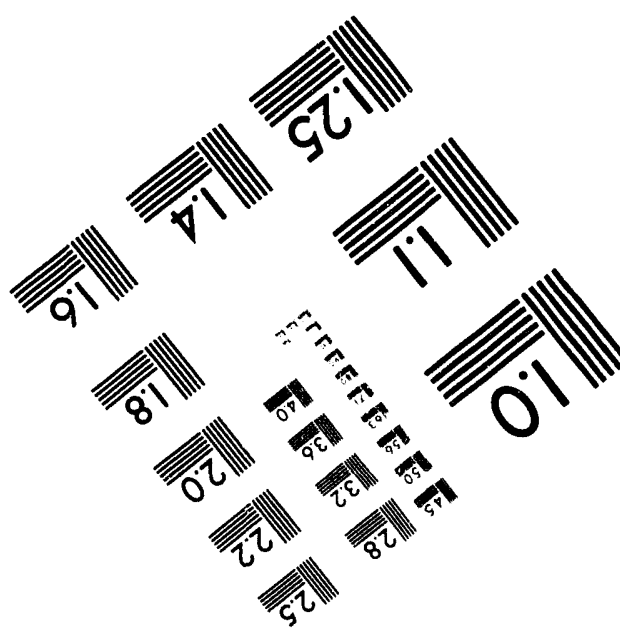



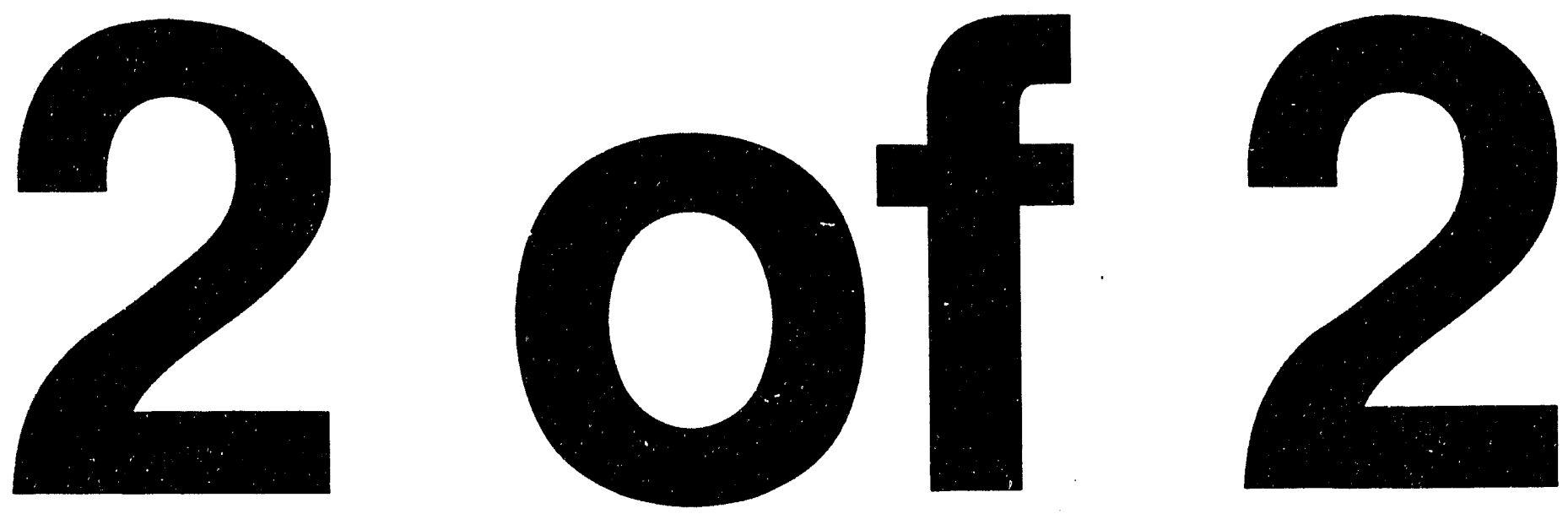


\section{Eaengy Information Administration \\ U.S. Department of Energy \\ Instructions for \\ Uranium Industry Annual Survey \\ Form EIA-858}

Survey Year 1993
Form Approved

O.M.B No. 1905.0160

Exptration Dute: 12/31/94

For asclotance conceralas the Form ELA-858,

contaet the Survey Menager on (202) $254-5565$.

\section{Purpose}

The Form EIA-858, "Uranium Industry Annual Survey", is used to collect date about the U.S. unnium industry. The datn are collected under authority of the Federal Energy Administration Act of 1974 (15 U.S.C. 2210b) and Section 1015 of the Energy Policy Act of 1992 (Public Law 102-486).

The data are used in these Energy Information Administration (EIA) publications: Uranium Industry Annual, Annual Energy Review, and the Uranium Purchases Report.

\section{Form'EIA-858 Format}

The two Schedules of Form EIA-858 collect industry dath about these topics:

$\begin{array}{cc}\text { Schedule } & \text { Topic } \\ \text { A } & \text { Uranium Raw Materials Activities } \\ \text { B } & \text { Uranium Marketing Activities }\end{array}$

Schedules A and B, which are included in this package, are mailed to respondents in late December of the Survey Year.

\section{Who Must Respond}

The Form EIA-858 must be completed by firms and individuals that were involved in the U.S. uranium industry (that is, within the 50 States, District of Columbia, Puerto Rico, the Virgin Islands, Guam, and other U.S. possessions) during 1992. Specific Criteria that define conditions for responding to all or portions of Schedules A and B are provided below under General Instructions.

\section{Sanetione}

The timely submission of EIA-858 by those required to repart is mandatory under section 13(b) of the Federnl Energy Administration Act of 1974 (FEAA) (Public Law 93-275), as amended. Failure to respond may result in a civil penalty of not more than \$2,500 for each violation, or a fine of not more than \$5,000 for each willful violation. The government may bring a fivil action to prohibit reporting violations which may result in a temporary restraining order or a preliminary or permanent injunction without bond. In such civil action, the court may also issue mandatory injunctions commanding any person to comply with these reporting requirements.

\section{When to Reepond}

Schedules A and B of the Form EIA-858 must be filed with the ELA by Warch 1, 1994.

\section{How and Where to Respond}

Schedules A and B of Form ElA-858 can be submitted by mail, either in hand copy or micro-computer diskette versions (see below), or by facsimile transmission.

Mall: Hard copy and micro-computer diskette versions should be mailed to: (A pre-addressed envelope is provided)

$$
\begin{aligned}
& \text { Energy Information Administration } \\
& \text { Mail Station: BG-094 Forrestal } \\
& \text { U.S. Department of Energy } \\
& \text { Weshington, D.C. } 20277-7091
\end{aligned}
$$

Facsimile (FAX): Respondents who do not use the diskette version and who want to submit Form EA-858 by FAX should call to inform the Survey Manager (see number above) of the incoming transmission. The FAX transmission number at the Technical Assistance Center (TAC), Energy Information Administration, $1707 \mathrm{H}$ Street, Washington, D.C. is shown below. The TAC is staffed Monday through Friday from 6:30 a.m. until 6:00 p.m. each day.

$\begin{array}{cc}\text { Transmianion } & \text { Verification } \\ \text { (202) 254-5765 } & (202) 254-5565 \\ (202) 254-6233 & (202) 254-5568\end{array}$

To essure successful data transmission by FAX, respondents should verify receipt of complete and legible datn pages at the ElA's Technical Assistance Center by calling a verification number shown above upon completion of datn transmission. The name of the person who verifies receipt of the transmission should be noted.

Micro-Computer Form EM-858: If you wish to receive the micro-computer version of Form EIA-858, contact the Survey Manager. This version operates on an IBM PC, PCXXT, PC/386, or compatible computer with either: (1) a noppy-disk drive (5 $1 / 4$ inch) plus a hard disk drive or (2) two floppy-disk drives. It requires a minimum system memory of 512 kdlo-bytes and the Disk Operating System (DOS), Version 2.0 or above. 


\section{OVERVIEW AND CRITERIA FOR SCHEDULES A AND B}

Overview

Your firm's name and address are preprinted on Form EIA-858. Selected data also are preprinted, where applicable, on Schedule A for uranium properties, mills, and plants and on Schedule B for contracts and uranium inveniories. The preprinted information, reported on your firm's Form EIA-858 for the previous Survey Year, is duplicated bere to aid in completing the current Form ElA-858. Review all preprinted information, and update, change, or correct it as necessary to report current Survey Year information.

A set of blank pages is provided for reporting data on other (not preprinted) uranium-reserves properties, mills, plants, and market commitments that your firm acquired during the Survey Year.

On page 1, complete the section "Applicability of Schedules A and $B^{n}$ by stating (in column b or c) whether Scbedule A (Parts I through IV) and Schedule B apply to your firm for Survey Year 1993. If Parts II and III apply, enter in column d the total number of reserves propertles, mill, and plants you are reporting. If Schedule B applies, enter the total number of contracte you are reporting.

Within a Part that is applicable to your firm, an Item that is not applicable should be marked as "NA." If zero or none is the answer to an Item, please enter a "O" or "none" for that Item, not the symbol "NA".

On page 1 , give the names and phone numbers of contact persons for the data reported on Schedules A and B, if different from the person who signed the certification statement.

If Schedules A and B are separated for completion by different persons in your firm, please provide a copy of the instructions with each Schedule.

If more space is needed to repont information for any Item, use the COMMENTS spaces provided at the end of each Schedule. Please key each comment or note to its Item number.

A Glossary is provided at the end of the instructions.

\section{Criteria for Responding to Form EIA.858}

In the Criteria below, controllers are firms or individuals that, by virtue of title, contrach, lease, or concession, own properties with uranium reserves or are responsible for the exploration and development of uranium reserves and the extraction of uranium as a primary product or byproduct; own or are responsible for the operation of uranium mines, mills, or processing plants; or are the operators of uranium-industry joint ventures.

$$
\text { Criteris for Sebedule A }
$$

Firms that during 1993:

A. Were controllers or were identified in EIA records as the most recent controllers of uranium-reserves properties and uranium mines, mills, or plents in the United States, including, but not limited to, those named on pages 3 and 5 of Form EIA858;

B. Were involved as controllers of uranium exploration and development ventures in the United States: U.S. firms that conducted in foreign countries uranium exploration and development activities that were funded by U.S. operations;

C. Incurred expenditures for uranium exploration in the Survey Year or plan such expenditures during the following year,

D. Held uranium reserves in specific properties by right of title, contract, lease, or concession and that were directly responsible for the development and exploitation of those reserves;

E. Were controllers of uranium mining properties, including firms that were controllers of mines under joint-ownership agreements or by contract agreements; firms that were controllers of in situ uranium recovery facilities; or

F. Were controllers of commercial extraction of uranium from ore (or leach solution) or as a byproduct of the processing of a different commodity.

\section{Criteria for Sehedule B}

Firms that during 1993:

G. Held existing contracts covering the Sale, Purchase, Exchange, Loan, or Loan Repayment of uranium or entered into similar new contracts; was the importer and/or exporter of uranium materials in conjunction with such contracts;

H. Held iranium materials and/or offered the service of storing such materials at any site in the United States under a holding agreement when the ownership of those materials remain with a forelgn entity;

I. Offered the service of enriching uranium materials in any form in the isotope ${ }^{233} \mathrm{U}$; 
J. Wes the setual entity that imported and/or exported unanium materials in conjunction with providing the services of unanium carichmeat, conversion, fuel fabrication, and/or transportition, regardless of who owned the uranium materials that were shipped;

K. Made actual deliveries of uranium feed materials to any enrichment supplier,
L. Held inventories of uranium in any form excluding reactor inserted, fabricated fuel; maintained a forward-coverage, uranium-inventory policy (utilities only).

M. (Utilities only) Purchased uranium enrichment services during 1993 from either the U.S. Enrichment Corporation, from a foreign enrichment supplier, or from both. 
Form EL-858 (12-92)

INSTRUCTIONS FOR COMPLETING

SCHEDULE A, URANIUM RAW MATERIALS AC'TIVITIES

\section{General Outline}

The four Parts of Schedule A cover:

$$
\begin{array}{ll}
\text { Part } & \multicolumn{1}{c}{\text { Topic }} \\
\text { I } & \text { Exploration and Development } \\
\text { II } & \text { Reserves and Mine Production by Property } \\
\text { II } & \text { Milling and Processing } \\
\text { IV Employment (including contractor support) }
\end{array}
$$

Data reported should be current to December 31, 1993.

Part I. Exploration and Development

Item 1. Jolnt Venture Arrangements

The controlling partner in a joint venture should report on the full ssope of activities conducted under the venture. To prevent duplicate reporting, the other venture partmers should not report dats for those same activities.

Item 2. Exploration Land Status and Cost for the Survey Year

Enter in the table the amount of land acquired in 1993 for uranium exploration. Examples of land that should be reported included: mineral fee, patented and unpainted mining claims, and options to purchase mineral fee land. Exclude land held for uranium production, and land beld in foreign countries.

Item 3. Exploration and Development Drilling by State and Total Cost

Enter by state the number of drill holes and footage completed during 1993 for exploration (include ascessment drilling) and development. Do not include drilling done-in foreign coumuries. Definitions of drilling categories are provided in the Glossary.

For projected drilling in the following year, enter on the line provided the numbers of drill holes and footage planned for exploration and development.

Item 4. Other Exploration and Development Expenditures

Report all other expenditures directly associated with your company's domestic exploration and development effort. Include expenditures for assessment work other than doilling. geological research; geochemical, and geophysical surveys; costs incurred by field personnel in the course of exploration work; and overhead and administrative charges directly associated with supervising and supporting field and exploration activities. Do not include expenditures for land acquisitions and drilling programs reported under Items 2 and 3 above or for internal corporate charges, such as directors' salaries, not directly associated with the company's exploration effort.
Item 5. Foreign Contributions to Exploration Expenditures

Report the percentages of your total exploration expenditures (sum of Items $2+3+4$ ) contributed by foreign-controlled companies in 1993 (Survey Year) and planned for 1994 (Following Year). Foreign controlled means majority-owned by non-U.S. encities.

Item 6. Expeaditures for Uranium Exploration in Foreign Countries

Report total exploration expenditures by country for 1993 (Survey Year) and amount planned for 1994 (Following Year).

\section{General Procedure Por Reaponding to Parts II, III and IV}

In a case of jointly-owned land, mine, mill, plant, or other entity for which data are requested under one or more items of Form EIA-858, the operating (or controlling) partmer must report the total data for that entity. That is, the data relative to each owner's participation in activities germane to an. Item must be included in your response given on Form EIA-858.

\section{Part II. Reserves and Mlae Production by Property}

Under Part II, the following data are requested for each property with uranium reserves controlled by your firm during 1993: quantity of uranium reserves and related costs, reservesestimation parameters, and conventional and nonconventional mine status and related mine production.

If, during 1993, your firm controlled other (not preprinted) uranium-reserves properties also complete Items 7 through 12 for each such property. A blank set of Items 7 through 12 (pages 3 and 4) is provided. Append additional pages at the end of Part II.

Item 7. Property Information

Property Name and Location: Enter property name and location information as requested. Give longitude and latitude to the nearest degree and minute.

Ornership: Self explanatory.

Controllership: If your firm no longer controls this property, give name, address, and phone number of the party to which it was transferred. If the property reverted to a State or Federal agency during the Survey Year, provide the name and address of the agency.

Status: Check oaly one box. If a mine was temporarily closed or permanenty closed, you must provide the date (MM/YY). Temporarily closed includes long-term closure, but is short of permanent closure.

Studies: Check all boxes that apply. 
Item 8. Property Uranium Reserves Estimates

For each reserves property, enter in the table your estimates of uranium reserves for the forward cost categories of $\$ 15, \$ 30$, S50, and $\$ 100$ by the mining method used to calculate the reserves. Report the reserves anticipated to be recoverable considering ore recovery and dilution. If reserves estimates are not available for the forwand cost categories shown, enter in the far right columns the cost category (or categories) you chose for estimating reserves and the quantity of reserves estimated at that cost by mining method.

Give the date (month/year) the reported estimates of reserves were made.

\section{Item 9. Operating Costs Used In Estimating Reserves}

Enter in the table the costs used in estimating reserves for this property. Definitions of cost terms are provided in the Glossary. If the costs for your reserves estimates are defined differently, enter your costs and state how they are defined (that is, what each cost includes) under Comments for Schedule $A$ on page 6. For openpit and underground mining, provide costs per ton of ore mined. For in situ leaching or other leaching, provide the average cost per pound of $\mathrm{U}_{3} \mathrm{O}_{3}$ recovered. Report all costs in current 1993 dollars.

\section{Item 10. Toth Copitul Corte by Minine_Method}

Enter in the table total capital costs (which includes development constnuction and equipmentexpendiures) for the chosen mining method for a mine or ISL field and for a mill or plant associated with this property. Report all costs in current 1993 dollars.

\section{Item 11. Drilling and Reserves Estimation Parameters}

Give total number of boles drilled, including barren holes, in the reserves outline on this property during 1993 and total holes drilled prior to 1993.

Enter in the table, by applicable mining method (openpit. underground, or in situ leach), the parameters used in calculating the reported estimates of reserves for this property.

Item 12. Mine Production and Shipments of Ore or Pregnant Solutions

Report quantities of ore and pounds mined to the nearest ton of ore and pound of $\mathrm{U}_{3} \mathrm{O}_{2}$ and $\mathrm{V}_{2} \mathrm{O}_{3}$.

Uranium and Vanadium Mined: Enter in the table the quantities of uranium and vanadium mined during 1993 for each applicable mining method. For in situ leaching, state the grade of ore. If quantities are reported for "Other" mining method, specify the method in the space provided.

Shipment of Ore or Preznant Solutions: Enter in the table the quantities of ore or pregnant solutions shipped to mills, plants, or to other sites during 1993. State the name of each mill, plant, or other site to which the shipments were made.

\section{Part III. Uranium Milling and Processing}

Under Part III, data are requested on the status of mills and plants, their operations, and production of uranium concentrate for 1993.

If your firm controlled other (not preprinted) uranium milling and processing facilities during 1993, also complete Items 13 through 16 for each such facility. A set of blank Items 13 through 16 (page 5) is provided. Append additional pages at the end of Part III.

\section{Item 13. Mill or Plant Information}

Name and Location: Enter mill or plant name and location information as requested. Provide longitude and latitude to the nearest degree and minute.

Ownershlp: Self explanatory.

Controllership: If your firm no longer controls this facility, give the name, address, and phone number of the party to which it was transferred. Mark one box to indicate the nature of the arrangement between your firm and the party to which the facility was transferred.

Item 14. Rated Capacity

Rated capacity is synonymous with nominal capacity and nameplate capacity.

\section{Item 15. Operating Status During Survey Year}

If the facility was not operated during the Survey Year, the date of the facility closing must be entered.

Note: The EIA might publish your firm's responses for the Rated Capacity and the Status at End of Survey Year for each mill and plant in selected data reports. Refer to the section "Provisions Regarding Confidentiality of Information" on page $\mathrm{x}$.

Item 16. Uranium Concentrate Production

Conventional Mills and Nonconventional Planta: Enter requested data on uranium concentrate production for each facility. Please include all concentrate produced from cleanup/reclamation operations. Mark all boxes necessary to indicate sources of "Other Mill Feed" and "Total Plant Feed."

\section{Part IV. Employment}

\section{Item 17. Employment by State}

Enter the number of person-years (see Glossary) by state expended by your firm during 1993 in uranium exploration, mining, milling, processing, reclamation (to include staff and contract personnel), and person-years for assessmeat work. Include person-years expended for standby and maintenance operations, site-security personnel and for contracted manpower paid for by your firm during the year. See "Person Year" in the Glossary. 


\section{INSTRUCTIONS FOR COMPLETING}

\section{SCHEDULE B, URANIUM MARKET ACTIVITIES}

\section{General Outline}

The six Items of Schedule B cover:

\begin{tabular}{cl} 
Item & \multicolumn{1}{c}{ Topic } \\
1 & Contract (Market Commitment) \\
2 & Uranium Inventories \\
3 & Utility Uranium Inventory Policy \\
4 & Actual Enrichment Feed Deliveries \\
5 & Projected Enrichment Feed Deliveries and \\
& Unfilled Market Requirements. \\
7 & Uranium used in Fuel Assemblies \\
7 & Enrichment Services Purchased by Utilities
\end{tabular}

Item 1. Contract (Market Commitment)

Item 1 covers Sale, Purchase, Exchange, Loan, Loan Repayment end/or Other contracts and Custody contracts active during 1993. Exchanges include physical-origin and ownership exchanges. Instructions for each contract type (transaction) are given below. Report each contract that was active at the end of 1993 or that was performed (completed) during 1993.

EIA must be able to account for all transfers of title to uranium materials during the Survey Year. Any transaction that involved the transfer of title, i.e., a Sale, Purchase, Exchange, Loan, Loan Repayment, or Other mechanism should be reported. A separate Item 1 must be completed to report the information requested under Items 1.A through 1.M for each quantity of uranium (Item 1.J) involved in a transfer of title during 1993.

Under certain conditions, a Sale or Purchase of separative work units (SWU) in the secondary market constitutes such a transfer. A Sale or Purchase of SWU that, in fach involves the transfer of a title to enriched uranium for a title to natural uranium, or viceversa, should be reported as an Exchange. A sale or purchase of SWU through assignment of an enrichment contract should not be reported on Form EIA-858.

Uranium materials of foreign ownership that were physically located during Survey Year at any of your company's sites should be reported under the Item 1.C.2 Custody Transactions. An example could be uranium materials entering the United States under a contribution of capital arrangement (but that does not result in a transfer of title to the custody company). For materials that fall under this category, a separate Item 1 must be completed to report the information requested under 1.A through 1.F and 1.J for each custody transaction during the Survey Year.

Data on active contracts reported on your firm's Form EIA-858 for the prior Survey Year might be preprinted under Item 1. If, during 1993, your firm beld or entered into other contracts (that is, those not preprinted), a separate Item 1 must be completed to report each such contract. A blank Item 1 (pare 7) is provided.
You may append copies of contract pages or quoted contract information after each Item 1, Contract, to report information that cannot be entered onto the form or to include additional information that will assist EIA in utilizing the contract data provided under ltem 1.

\section{A. Name of Other Party}

Self explanatory.

\section{B. Date Contract Signed}

Give the date a contract was originally signed. If applicable give the latest date it was renegotiated and indicate whether this was price related.

\section{c. Types of Transactions}

Transfer of Title: Indicate whether a contract is a Sale, Purchase, Exchange, Loan, Loan Repayment, or Other by marking the appropriate boxes. If Other, specify. If more than one transaction type is involved, mark the first with the number 1. the second with the number 2 and so on

For a Loan and Loan Repayment, indicate whether your firm was the Lender or the Borrower. A Purchase or Sale of SWU by, in effech, transferring title of enriched uranium for natural uranium (or vice versa) should be reported as an Exchange. Please indicate if this transaction involves an intracompany transfer of material.

Custody: If this transaction involves taking custody to uranium materials under a storage or holding agreement, mark this box. If other, specify.

Note that the question relating to intracompany transfer of materials in order to meet a contractual obligation being reported applies both to transfer of title and to custody transactions. Please answer Yes or No, as appropriate.

\section{Type of Material Covered Under this Contract}

Mark the appropriate box (or boxes) to indicate the material type (or types) sent or received under this contract. If more than one type of material is marked, explain under Comments.

\section{E. Origin and Destination}

State the country of uranium mining, of conversion service, and of enrichment service corresponding to the type of material marked under $D$. The term Actual refers to material delivered during the Survey Year; the term Future refers to material to be delivered during a future year. If the Future material can have more than one origin and destination, state the material types, countries, quantities, and prices applicable under Comments. If the contract does not specify the country where the uranium was mined or the country of component-service performance, please write in "Unspecified." 
Provide the country of destination for the Actual and Future (estimated) uranium commitments (or SWU transfer agreement). Country of destination refers to the country to which the material ultimately will be delivered under this contract.

\section{F. Importation and Exportation of Uranium}

Recelvers: Indicate whether your firm is importing material under this contract, and, if so, name the shipping facility.

If your firm is buying uranium from a foreign company and taking title after it has entered the United States, this is considered an importation by your firm. Foreign-origin uranium already within the United States bought by your firm from another U.S. company is not an importation by your firm.

Foreign-origin uranium, located at a foreign site, that is purchased, borrowed, or exchanged by your firm and then is sent directly to another foreign destination is not an importation until the uranium enters the United States. The transaction, however, should be reported under Item 1.

Shippers: Indicate whether your firm is exporting uranium under this contract, and, if so, name the country of end use: that is, the country to which the uranium ultimately will be delivered under this contract. Exports can include loans and loan repayments.

If your firm is delivering uranium to a foreign firm that will take title to the uranium within the United States and will then ship it to a foreign destination, this should be reported as an export by your firm.

\section{G. Pricing Mechanism}

For a Sale or Purchase contract, indicate whether the pricing mechanism is "Contract Specified", "Market-Price Related", or "Other." Indicate under Contract Specified or Market-Price Related the appropriate pricing-mechanism mode.

In a Contract Specified contract, price is determined at the time of contract signing as either a Fixed Price or a Base Price with escalation factors. Spot and secondary-market purchases can be reported as Contract Specified.

In a Market-Price Related contract price commonly is determined at or before delivery and is based on price prevailing at the time of delivery. If price is, or will be, tied to an external indicator (e.g., published spot price), mark "External Indicator" as the settlement mode. If price is settled by arm's-length negotiation, mark "Negotiated" os the settlement mode.

A Market-Price Related contract can have either an expiicit floor price or a cost-related floor pice. Mark all applicable boxes.

In some contracts, price is defined as the higher of either baseprice escalated or market price. These contracts should be reported as Market-Price Related with a floor price rather than as Contract Specified.

Indicate whether the contract has provision for a Ceiling Price.
"Other" includes complex-pricing-mechanism contracts that do not fit readily into the Contract Specified or Market-Price Related categories. Describe the mechanism under Comments.

Other is always the pricing-mechanism category for a captive operation.

If a contract provides for delivery under a contract-price arrangement for a portion of the delivery period and under a market-price arrangement for the remainder of the period, you should follow instruction " $a$ " or " $b$ " below. Complete either:

(a) a separate Item 1 for each relevant combination of quantity-price-period (years) in the contract, or

(b) a single Item 1 and explain under Comments the period (years) for each quantity-price combination.

If a contract covers deliveries of materials of different origins at different prices, explain under Comments each combination of quantity-price-period (years). If a contract specifies a "flat" fee, as in a Loan, yois may explain the fee arrangement under Comments. Please key your comments to specific contracts.

\section{H. Litigation Status}

Self explanatory.

\section{Contract Options}

Indicate whether the contract permits (at the buyer's or seller's option): (1) delivery of optional quantities (amount specified); (2) delivery of additional quantities (amount not specified); (3) cancellation of some or all deliveries; (4) substitution of material not from the seller's own production; and/or (5) change in delivery dates. Explain other options or flexibility in the contract under Comments for Schedule B.

\section{J. Uranium Quantity}

State the actual quantities of uranium, in thousand pounds $\mathrm{U}_{3} \mathrm{O}_{8}$ equivalent, that changed ownership under a contract during 1993 and the Firm and/or Optional quantities specified in the contract for delivery in future years. If different types of material are specified for any given year, state the amount of each type under Comments for Schedule B.

If $\mathrm{UF}_{6}$ is the material under contract, give under $J$ the $\mathrm{U}_{3} \mathrm{O}_{8}$ equivalent assuming a 0.20 percent $U-235$ tails assay value:

Under a Market-Price contrach, if the price for 1993 and/or 1993 deliveries was settled by December 31, 1993, state the yearly quantities on the Settled Price rows. If the price for deliveries was not settled by December 31, 1993, state the yearly quantities on the Not Settled Price rows.

For a contract with Contract Specified or Other pricing mechanism, state the 1993 quantity in the Settled Price row. 


\section{K. Market-Price; L. Contract-Price; and M, Other Procurement}

Prices need not be reported for Exchange, Loan, and Loan Repayment contracts and for captive production.

Enter actual price per pound $\mathrm{U}_{3} \mathrm{O}_{8}$ for 1993 and 1994 deliveries. For future years, enter estimated or fixed prices. Enter prices by column according to pricing mechanism marked under $\mathbf{G}$ above.

If contract quantities are quoted in $\mathrm{UF}_{6}$ or other terms, convert to equivalent $\mathrm{U}_{3} \mathrm{O}_{6}$ values net of the $\mathrm{UF}_{6}$ conversion cost.

For each year beyond 1993, give prices both in nonescalated dollars (use a factor of " 1 ", or zers escalation) and in escalated dollars using either contract-specified escalators or your best estimate of escaiators. The escalated column should contain the actual price paid or received for deliveries in 1993 and 1994 (when applicable), and estimates of future year's prices based on the price-escalation factors specified in the contract.

For a contract-price procurement with a fixed price, report the fixed price in Item 1.L using the column entitled Escalated.

For a market-price contract without a settled price, enter the floor price if applicable. Statri escalated and nonesalified floor prices as appropriate. If the floor price is expressly felated to a seller's production cost and the production cost canhot be estimated, enter "Cost" in the Settled Price column. If price is not settled in a market-price contract without a floor, leave $K$ blank; however, do report applicable quantities under column J.

\section{Item 2. Uranlum Inventories}

State the inventory quantities, both domestic- and foreign-origin, to which your firm held title as of December 31, 1993, including uranium under financial lease. Reforted quantities should agree with inventory quantities reported last year and with data provided elsewhere in Form ElA-858. That is, 1993 inventory values should reflect last year's values (which are preprinted) with adjustments for subsequent stock additions, purchases, sales, and usages, etc., reported on other parts of this form. Please revise the preprinted values for 1992 to report any corrections for those data.

Item 3. Utillty Uranium Inventory Poliey

Mark the box to indicate whether your company has a uranium inventory policy. If Yes, fill in the table for each applicable type of inventory. The sum of the inventory values should equal your total desired inventory.

\section{Item 4. Actual Uranium Enrichment Feed Dellveries}

Enter the quantities of uranium feed materials (both U.S.- and foreign-origin) shipped to U.S. Department of Energy (DOE) or U.S. Enrichment Corporation (USEC) enrichment plants and to foreign enrichment plants in 1993.

Do not include deliveries placed in your DOE/USEC usage agreement account that are not intended for withdrawal until 1993 or later. Withdrawals of enriched uranium from your usage agreement account in 1993, however, should be included as appropriate in your feed deliveries to DOE/USEC plants.

State under S.E the equivalent of DOE/USEC separative work units (SWU) that your firm purchased in the secondary market in 1993.

Item 5. Projected Enrichment Feed Dellveries and Unflled Market Requirements

In the left-band column, enter your firm's total projected shipments to enrichment service suppliers (DOE/USEC- plus foreign-enrichment suppliers) for each year. Include enriched uranium (SWU) to be received through all purchase and exchange contracts in effect as of December 31, 1993. Exclude feed deliveries of uranium scheduled for a canceled reactor, unless the enriched product will be used in another of your firm's reactor units.

In the right-hand column, enter your firm's total unfilled market requirements for each year.

\section{Item 6. Uranium Used In Fuel Assemblies}

This item is to be answered only by utilities. Report only the total of unirradiated uranium in fuel assemblies loaded into reactors in 1992 and 1993, by origin. Do not include uranium removed from reactors that subsequenty will be reloaded.

Item 7. Enrichment Services Purchased by Utllitles

In accordance with Section 1015 of the Energy Policy Act of 1992 (P. L. 102-486), Domestic Utilities are required to report their purchases of enrichment services during the survey year. Please include the name, quantity, and country location of the seller. 


\section{GLOSSARY}

Acqublition Coat: Cost of acquiling mining and production inghts to a uranium property.

Acesesmont Work: The annual or biennial work performed on a mining claim (or clalms), after cla/m location and before patent, to beneflt or develop the clalm and to protect It from relocation by third parties.

Break-oven Cutcif Grads: The lowest grade of material that can be mined and proceseod considering all applicable costs, without incurring a loss or gaining a profit.

Capilal Coet: Cost of mine development and mill or plant construction and the equipment required for the production of uranium from a property, exchuding sunk costs.

Dovalopment Driling: Drilling done in an ore deposit to determine more precisely size, grade, and conflguration subsequent to the time the determination is made that the deposit can be commercially developed. Not included are: (1) secondary development drilling, (2) solution-mining drilling for production, or (3) production-related underground and openpit driling done for control of mining operations.

Direct Mining Coet: Operating costs directly attributable to the processing of ores or other feed materials inctuding labor, supervision, engineering, power, fuel, supplies, reagents, and maintenance.

Direct Mining Coet: Operating cost directly attributable to the mining of ore including costs for labor, supervision, engineering, power, fuel, supplies, equipment replacement, inaintenance, and taxes on production.

Exploration Driling: Drilling done in search of new mineral deposits, on extensions of known ore deposits, or at the location of a discovery up to the time when the company decides that suffictent reserves are present to justify commercial development. Assessment drilling is reported as exploration drilling.

Forward Coat: Forward costs are those operating and capital costs yet to be Incurred at the time an estimate of reserves is made. Profits and 'sunk' costs, such as past expenditures for property acquistion, exploration, and mine development, are not included. Therefore, the various forward-cost categories are independent of the market price at which uranium produced from the reserves would be sold.

Haulage Coot: Cost of loading ore at a mine site and transporting it to a processing plant.

Indirect Cost: Costs not directly related to mining or milling operations, such as overhead, insurance, securtty, office expenses, property taxes, and similar administrative expenses.

In Shu Leach Mining (1SL): The recovery, by chemical leaching. of the valuable components of an ore body whithout physical extraction of the ore from the ground. Also reforred to as 'solution mining.'

Min Caplial: Cost for constructing and equipping a plant for processing ore or other foed materials.

Mino Capilal: Cost for exploration and dovelopment, premining stripping, shaft sinking and mine development (inchuding in situ leaching), and the mine plant and its equipment.

Other Capital Cocts: Costs for Hems or actlvities not included elsewhere under capital-cost tabulations, such as for and decommissioning, dismantling, and reclamation.

Other Operating Coets: Costs for othor Heme or actlvilties not included elsewhere in operating-cost tabulations, but required to support the calculation of $a^{\circ}$ cutoth grade for ore reserves estimation.

Pereon Year: One whole year, or fraction thereof, worked by an employee, Including contracted manpower. It is expressed as a quotient (to two decimal places) of the time units worked during a year (hours, weoks, or months) divided by the like total time units in a year. For example: 80 hours worked is 0.04 (rounded) of a porson year; 8 weeks worked is 0.15 (rounded) of a person year; 12 months worked is 1.0 person year. Contracted manpower includes survey crews, drilling crews, consultants, and other persons who worked under contract to support your firm's ongoing operations.

Proceseling: Uranlum-recovery operations whether at a mill, an in sits leach, byproduct plant, or other type of revovery operation.

Roservo Coat Catogoribs of \$15, \$30, \$50, and \$100 per Pound $U_{3} O_{\text {: }}$ : Classification of uranlum reserves estimated by using break-even cutoff grades that are cakculated based on forward-operating costs of le than \$15,\$30,\$50, and $\$ 100$ per pound $\mathrm{U}_{3} \mathrm{O}_{\text {. }}$.

Royalty Coet: A share of the proflt or product reserved by the grantor of a mining leaso, such as a royalty pald to a lesseo.

Separathe Work Unit (SWU): The standard measure of enrichment services. The effort expended in separating a mass $F$ of feed assay $x_{F}$ into a mass $P$ of product of assay $x_{p}$ and wasto of mass $W$ and assay $x_{w}$ is 
expressed in terms of the number of separatlve work units needed, given by the expression

$$
s W U=W V\left(x_{W}\right)+P V\left(x_{p}\right)-F V\left(x_{F}\right)
$$

where $V(x)$ is the "value function," defined as

$$
V(x)=(1-2 x) \ln \left[\frac{1-x}{x}\right]
$$

Sunk Coat: Part of the capital costs actually incurred up to the date of reserves estimation minus depreciation and amortization expenses. Items such as exploration costs, land acquisition costs, and costs of financing can be Included.

Uranium Exportation: The actual physical movement of uranium from a location inside the United States to a location outside the United States.

Uranim Importation: The actual physical movement of uranium from a location outside the United States to a location Inside the United States.
Uranimm Property: A specific tract of land whth known uranlum reserves that could be developed for mining.

Uranium Rosenves: Estimated quantitles of uranium in known mineral deposits of such size, grade, and configuration that the uranium could be recovered at or bolow a specified production cost with currently proven mining and processing technology and under current law and regulations. Reserves are based on direct radiometric and chemical measurements of drill hole and other types of sampling of the deposits. Mineral grades and thickness, spatial relationships, depths below the surface, mining and rectamation mothods, distances to milling facllities, and amenablilty of ores to processing are considered in the evaluation. The amounts of uranium in ore that could be explolted within the chosen forward-cost levels are estimated utilizing avallable sampling, engineering. geologic, and economic data in accordance with conventional engineering practices.

\section{PROVISIONS REGARDING CONFIDENTIAUTY OF INFORMATION}

The following information and data elements will not be treated as confidential by the EIA:

a. Rated capacity of a conventlonal mill (under ltem 14).

b. Rated capacity of a nonconventional plant (under ltem 14).

c. Operating status of a facility at the end of the Sunvey Year (under ltem 15).

Othenwise, the Offlce of Legal Counsel of the Department of Justice concluded on March 20, 1991, that the Federal Energy Administration Act requires the Energy Information Administration to provide company-epecific data to the Department of Justice, or to any other Federal agency when requested for officlai use, which may include enforcement of Federal law. The information contained on this form may also be made avallable, upon request, to another component of the Department of Energy (DOE); to any Committee of Congress, the General Accounting Office, or other Congressional agencles authorized by law to recelve such information. A court of competent jurisdiction may obtain this information in response to an onder.
The Information contained on this form will be kept confidential and not disclosed to the public to the extent that it satiefies the criteria for exemption under the Freedom of Iniormation Act (FOIA), 5 U.S.C. 5552, the DOE

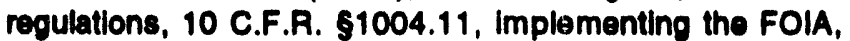
and the Trade Secrets Act, 18 U.S.C. 61905.

Upon recelpt of a request for this infermation under the FOIA, the DOE shall make a final determination whether the information is exempt from disclosure in accordance with the procedures and criteria provided in the regulations. To assist us in this determination, respondents should demonstrate to the DOE that, for example, their information contains trade secrets or commercial or financial information whose release would be likely to cause substantial harm to their company's compettive postition. A letter accompanying the submission that explains (on an element-by-element basis) the reasons why the information would be llkely to cause the respondent substantial competitive harm if released to the public would aid in this determination. A new justiflcation does not need to be provided each time information is submitted on the form, if the company has previously submitted a justification for that information and the justification has not changed. 
Data on this mandatory survey are collected under authority of Section 170B of the Atomic Energy Act of 1954, as amended (42 U.S.C. 790 a), and the Federal Energy Administration Act of 1974 (IS U.S.C. 2210b). Provisions regarding sanctions are described in Part IV, page $i$ of the instructions. Provisions regarding the confidentiality of information submitted in response to this survey are set forth on page $x$ of the instructions for Schedules A and B.

The publlc reporting burden for this form is estimated io average 25.0 hours per response, including the time of reviewing instructlons, searching existing data sources, gathering and maintaining the data needed, and completing and reviewing the collection of information. Please send your comments about this burden estimate, suggestions for reducing this burden, or any other aspect of this crllection of information to: the Energy Information Administration. Office of Statistical Standards, EI-73, 1000 Independence Avenue SW, Washington, DC 20585; and to the Office of Information and Pegulatory Affairs, Offlce of Management and Budget, Washinglon, DC 20503.

\section{RESPONDENT IDENTIFICATION}

Company Name:

Address:

City: State: Zip:

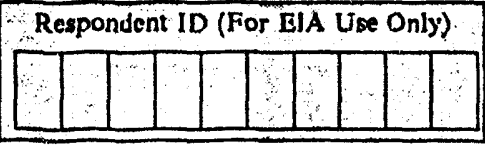

Parent Company:

\section{APPLICABILITY OF SCHEDULES A AND B}

Check one box on each line under column (b) or (c). If Part II and Part III are applicable, give in column (d) the total number of properties and mills or plants reported. If Schedule $B$ is applicable, give the total number of contracts (Item 1 of Schedule B) reported.

\begin{tabular}{|c|c|c|c|}
\hline 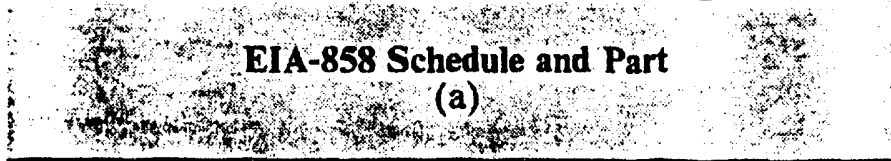 & $\begin{array}{l}\text { Applies to } \\
\text { This } \\
\text { Company } \\
\text { (b) }\end{array}$ & $\begin{array}{l}\text { Does Not } \\
\text { Apply to This } \\
\text { Company } \\
\text { (c) }\end{array}$ & $\begin{array}{l}\text { Number } \\
\text { Submitted } \\
\text { (d) }\end{array}$ \\
\hline A. Part I: Exploration and Development & $\square$ & $\square$ & $x+1$ \\
\hline A. Part II: Reserves and Mine Production by Property & $\square$ & $\square$ & \\
\hline A, Part III: Uranium Milling and Proccssing & $\square$ & $\square$ & \\
\hline A, Part IV: Employmont & $\square$ & $\square$ & 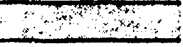 \\
\hline B: Uranium Marketing Activities & $\square$ & $\square$ & \\
\hline
\end{tabular}

\section{CONTACT PERSONS}

Schedule A: Name:

Schedule B: Name:

Phonc:

Phone:

\section{CERTIFICATION}

I certify that the historical and estimated information provided hereon and appended hereto are true, complete, and accurate to the best of my knowledge, information, and belief.

Name (Please print):

Title:

Signature:

Date:

Phone: (

Title 18 U.S.C. 1001 makes it a crime for any person knowingly and willingly to make to any Agency or Department of the United States any false, fictitious or fraudulent statement or misrepresentation as to any matter within its jurisdiction. 


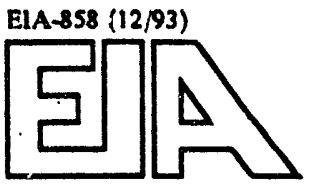

Energy Information Administration

U.S. Department of Energy

Uranium Industry Annual Survey

Survey Year 1993

SCHEDULE A: URANIUM RAW MATERIAL ACTIVITIES

Part I: Exploration and Development

\section{ITEM 1: JOINT VENTURE ARRANGEMENTS}

Was your company the controlling partner in one or more joint ventures in the Survey Year? $\square$ Yes $\square$ No If "Yes", list names of joint ventures. If "No", go to ltem 2.

1.

2.

3.

ITEM 2: EXPLORATION LAND STATUS AND COST FOR THE SURVEY YEAR
4.

5.

6.

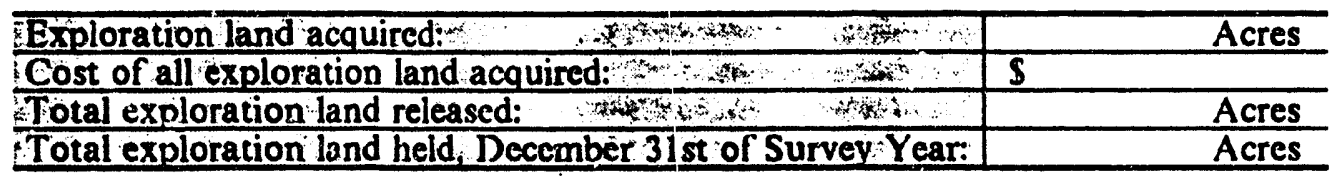

ITEM 3: EXPLORATION AND DEVELOPMENT DRILLING BY STATE AND TOTAL COST

Survey Year Drilling: Include drilling donc for assessment under exploration drilling.

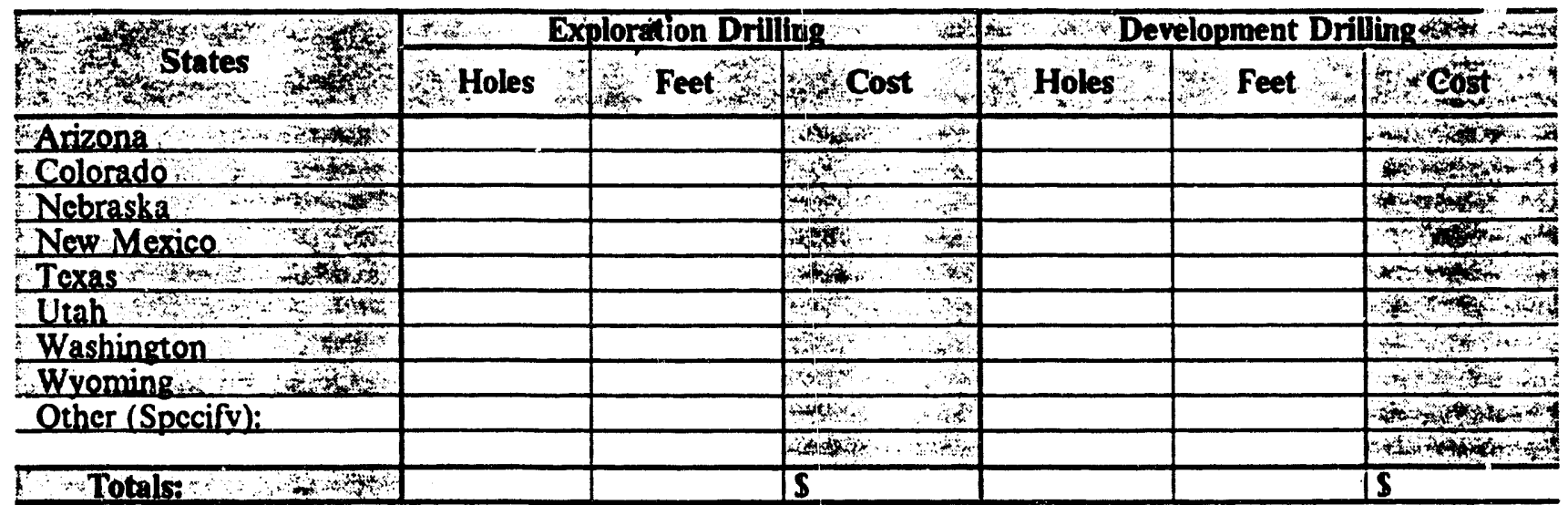

Following Year:

Brulected: Prtimates:

ITEM 4: OTHER EXPLORATION AND DEVELOPMENT EXPENDITURES

(Include assessment activities)

All other expenditures: $\mathbf{S}$

\section{ITEM 5: FOREIGN CONTRIBUTIONS TO} EXPLORATION EXPENDITURES

Contribution by foreign-owned companies:

Survey Year:
Following Year (planned): $-\%$ 


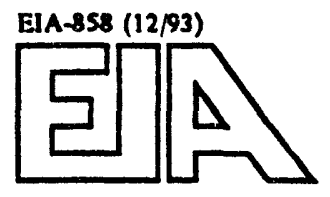

Energy Information Administration

U.S. Department of Energy

Uranium Industry Annual Survey

Survey Year 1993

SCHEDULE A: URANIUM RAW MATERIAL ACTIVITIES

Part Il: Reserves and Mine Production by Property

\section{ITEM 7: PROPERTY INFORMATION}

Identification:

Property Name:

Other Name(s) Used:

State:

\begin{tabular}{|c|c|c|c|c|}
\hline 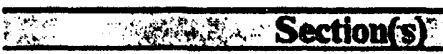 & 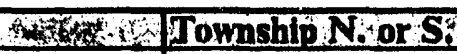 & Ringe: $\mathrm{E}$ or:W: & Latitude $\mathrm{N}:$ & Longitudex: \\
\hline & & & $\mathrm{N}$ & $\bar{W}$ \\
\hline & & & $N$ & $\mathbf{W}$ \\
\hline & & & $\mathrm{N}$ & $\circ$ \\
\hline
\end{tabular}

Ownership:

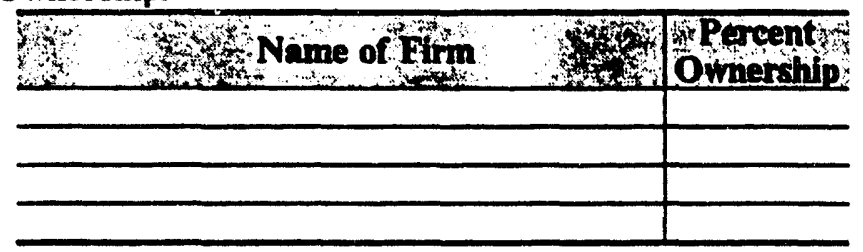

Controllership:

If your firm no longer controls this property, identify the party to which it was transferred:

Name:

Address:

City:

Phone: State: Zip:

Status (Check only one):

$\square$ Only assessment work being done

$\square$ Exploration continuing

$\square$ Exploration completed

$\square$ Development drilling complete

$\square$ Under development for production

$\square$ Mine in production

$\square$ Mined out

$\left.\begin{array}{l}\square \text { Mine closed temporarily } \\ \square \text { Mine closed permanently }\end{array}\right\} \overline{\mathrm{MM} / \overline{\mathrm{YR}}}$

Studies Completed (Check all that apply):

$\square$ Preliminary reserves estimate

$\square$ Final reserves estimate

$\square$ Preliminary feasibility study

$\square$ Final feasibility study

$\square$ Mining plan

\section{ITEM 8: PROPERTY URANIUM RESERVES ESTIMATES}

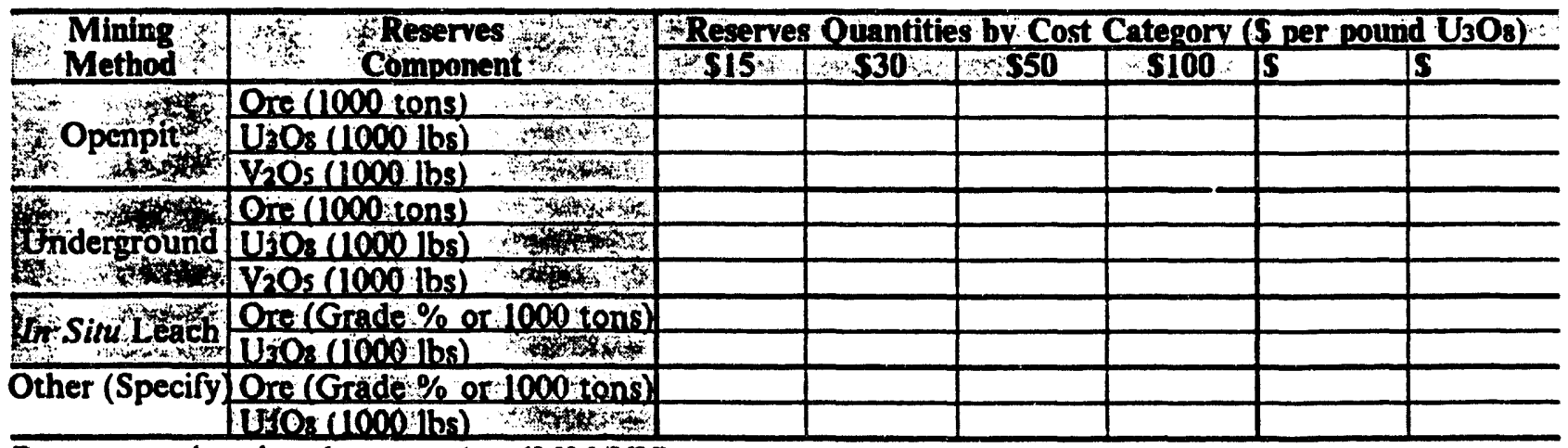

Reserves estimation date: (MM/YY)

\section{ITEM 9: OPERATING COSTS USED IN ESTIMATING RESERVES}

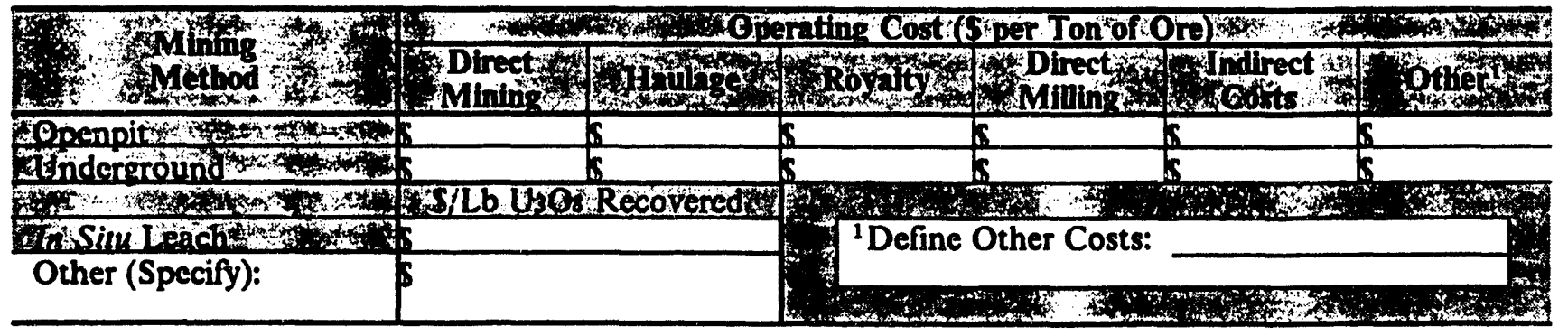

Page 3 
Property Name:

\section{ITEM 10: CAPITAL COSTS BY MINING METHOD}

Capital Costs for Development, Construction and Equipment

\begin{tabular}{|c|c|c|}
\hline \multirow{2}{*}{ Whining Method } & \multicolumn{2}{|c|}{ Capital Costs } \\
\hline & Mire or ISL Field & $\sqrt{\text { Mill or Plant }}$ \\
\hline Openpit kiknt? & & $\kappa$ \\
\hline Ufinderground 4 an & & $\mathrm{s}$ \\
\hline 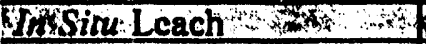 & & $\mathrm{s}$ \\
\hline 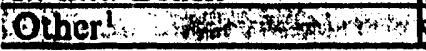 & & 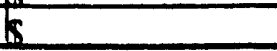 \\
\hline
\end{tabular}

\section{ITEM 11: DRILLING AND RESERVES ESTIMATION PARAMETERS}

Number of holes drilled, including barren holes, in the reserves outline:

During the Survey Year: ___ Holes. Prior to the Survey Year:____ Holes.

\begin{tabular}{|c|c|c|c|}
\hline 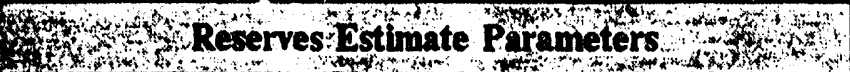 & Openpit, & Underground & Instifl Leach \\
\hline Break-even cutolf grade (Percent $\left.\mathrm{U}_{3} \mathrm{O}_{3}\right)$ & & & cons \\
\hline 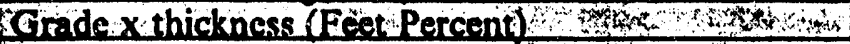 & B. & $3 x$ & \\
\hline 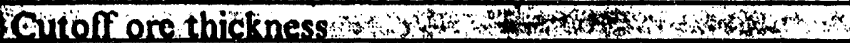 & 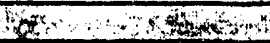 & 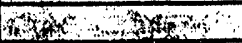 & \\
\hline EMinimum minine hejoht (Faet) & & & 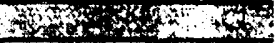 \\
\hline 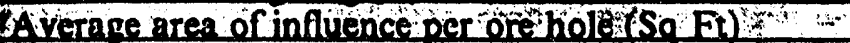 & & & \\
\hline Tonnage factor (Cubic Ecet pert o n) & & & \\
\hline Minc Recovery factor (Percent) & & & \\
\hline Mill or plant recovery (Percent) & & & \\
\hline Avernge depth to ore (Feet) & & & \\
\hline kness (Fret) & & & \\
\hline 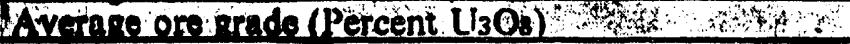 & & & \\
\hline
\end{tabular}

\section{ITEM 12: MINE PRODUCTION AND SHIPMENTS OF ORE OR PREGNANT SOLUTIONS}

\section{Uranium and Vanadium Minad}

\begin{tabular}{|c|c|c|}
\hline MVining Method & 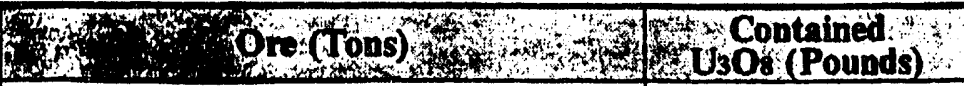 & $\begin{array}{l}\text { Cointhlined } \\
\text { Vos:(Poinds) }\end{array}$ \\
\hline Sopenpit & & \\
\hline Andergrounde & & \\
\hline Din Sindeach & (Grade): & Dof \\
\hline Oother 1 o & (Tons or Grade): & 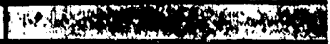 \\
\hline
\end{tabular}

\section{Shipments of Ore or Pregnant Solutions}

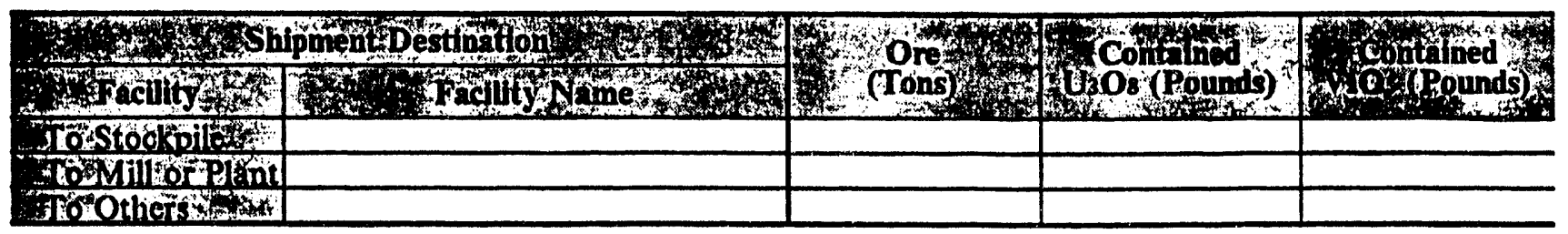




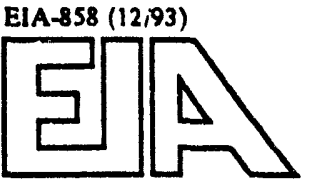

Energy Information Administration

U.S. Department of Energy

Uranium Industry Annual Survey

Survey Year 1993

SCHEDULE A: URANIUM RAW MATERIAL ACTIVITIES

Part III: Uranium Milling and Processing

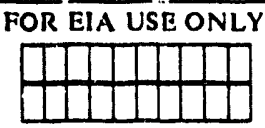

ITEM 13: MILL OR PLANT INFORMATION

Name and Location:

Facility Namc:

Other Name(s) Used:
Type of Facility:

$\square$ Conventional mill

State: _ $\square$ Nonconventional plant

\begin{tabular}{|c|c|c|c|c|}
\hline Q & Township N. or S. & Range E or W: & Latitude $N$. & Lonqitude:W. \\
\hline & & & $\bar{N}$ & $\overline{\mathrm{W}}$ \\
\hline & & & $\bar{N}$ & $\bar{W}$ \\
\hline & & & $\overline{\mathrm{N}}$ & $\overline{\mathrm{W}}$ \\
\hline
\end{tabular}

Ownership:

\begin{tabular}{|l|l}
\hline W Name of Fim & Percent \\
\hline & Ownership \\
\hline & \\
\hline & \\
\hline
\end{tabular}

Controllership:

If your firm no longer controls this facility, identify the party to which it was transferred:

Name:

Address:

City: Phone: State: Zip:

Indicate the nature of the arrangement between your firm and the firm named above (mark onc):

$\square$ Title transfer $\square$ Contract $\quad \square$ Leasc $\square$ Other arrangement (Specify):

Conventional mill (Tons ore per day)

Nonconventional plant ( $\mathrm{Lbs} \mathrm{U}_{3} \mathrm{O}_{8}$ per $\left.\mathrm{yr}\right)^{1}$

'See provisions :egarding confidentiality

of information in the instructions.

\section{ITEM 15: OPERATING STATUS DURING SURVEY YEAR}

Number of days opcrated in Survey Year. Nominal:

Days Actual:

Days

Was facility opcrated throughout Survey Ycar? $\square$ Yes $\square$ No If No, give closing date: ___

Was facility operating at end of Survey Year? ${ }^{1}$ Yes $\square$ No

IT acility did not operate during Survey Year:

$\square$ Closed temporarily (Restart planned for Following Ycar) Holding (standby) cost per year S

Closed indefinitely (Following Year restart not planned) Onc-time cost to reopen

$\square$ Closed permanently (Will not be restarted)

$\square$ Reclaimed (Restoration in progress or completed)

$\square$ Other status (Please specify):

TSee provisions on conlidentiality of intormation in the instructions.

\section{ITEM 16: URANIUM CONCENTRATE PRODUCTION}

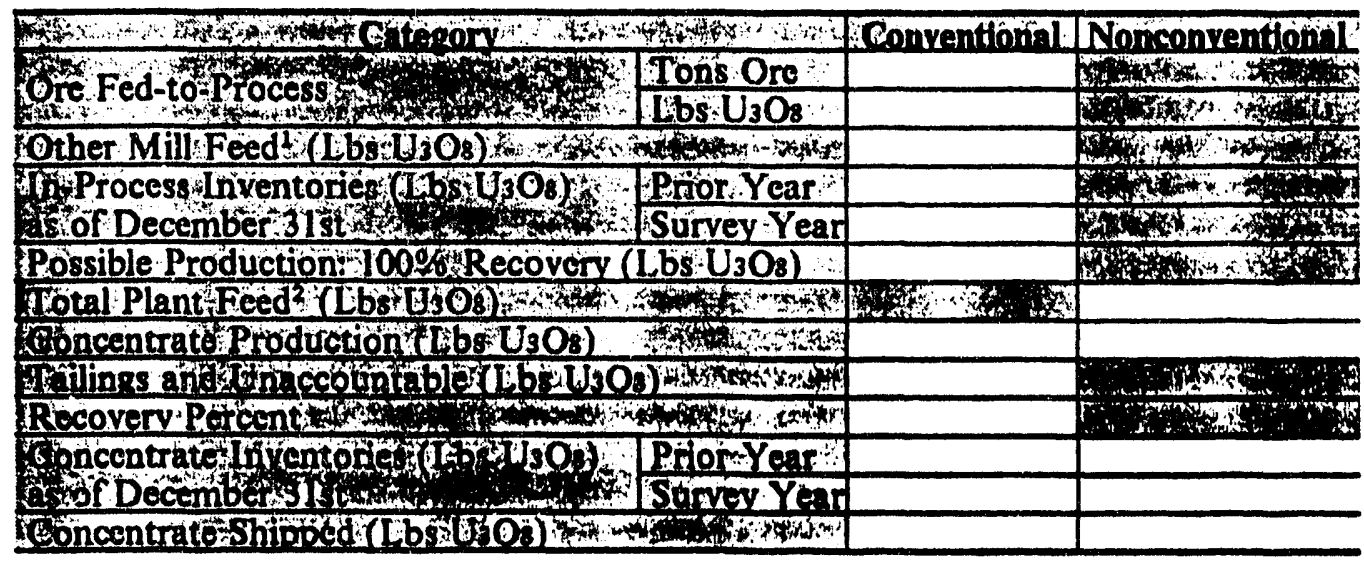

TOther Mill Feed:

(Check all sources)

$\square$ Mine water

$\square$ Heap lcach

$\square$ Tailings water

$\square$ Other (Specify):

${ }^{2}$ Total Plant Feed:

(Check all sources)

In situ Leach

$\square$ Reclamation

$\square$ Byproduct recovery

$\square$ Other (Specify): 


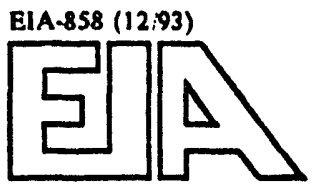

Energy Information Administration

U.S. Department of Energy

Uranium Industry Annual Survey

Survey Year 1993

SCHEDULE A: URANIUM RAW MATERIAL ACTIVITIES

Part IV: Employment

\section{ITEM 17: EMPLOYMENT BY STATE}

\begin{tabular}{|c|c|c|c|c|c|c|}
\hline \multirow{2}{*}{$\begin{array}{r}\text { Sthtes } \\
\text { Strot }\end{array}$} & \multirow{2}{*}{ 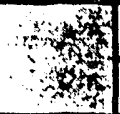 } & \multicolumn{5}{|c|}{ Employment (Person-Years): Include staff and contract personnel. } \\
\hline & & Exploration & Mining & $\therefore$ Malling & Processing & Reclamation \\
\hline \multicolumn{7}{|c|}{ Arizona } \\
\hline \multicolumn{7}{|c|}{ Colorado tast } \\
\hline \multicolumn{7}{|c|}{ Floridant -6} \\
\hline \multicolumn{7}{|c|}{ 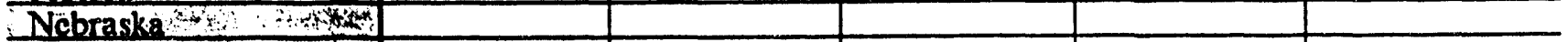 } \\
\hline \multicolumn{7}{|c|}{ New Mexico } \\
\hline \multicolumn{7}{|c|}{ 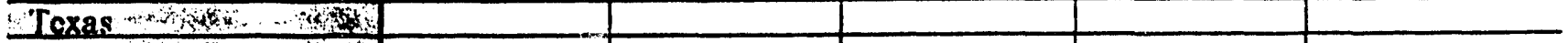 } \\
\hline \multicolumn{7}{|c|}{ 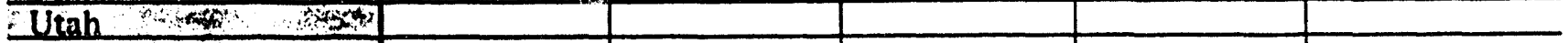 } \\
\hline \multicolumn{7}{|c|}{ Washington } \\
\hline \multicolumn{7}{|c|}{ Wyomino,} \\
\hline \multicolumn{7}{|c|}{ Other (Speci(y): } \\
\hline & & & & & & \\
\hline$=$ Tatnle: & 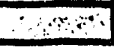 & & & & & \\
\hline
\end{tabular}

COMMENTS FOR SCHEDULE A 


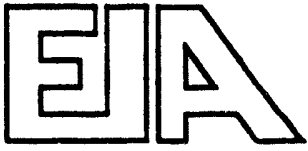

\section{SCHEDULE B: URANIUM MARKETING ACTIVITIES}

ITEM 1: CONTRACT: Complete one copy of this page for each contract (market commitment andior custody transaction) your firm had in place on December 31 of the Survey Ycar.

If not applicable, check box.

A. Other Party Name:

FOR EIA USE ONLY:

B. Date Contract Sizned:

Date Contract Renegotiated: - I

C. 1. Transfer of Title: Mark in order.

$\square$ sale $\square$ Purchase $\square$ Exchange

$\square$ Check ir the renegotintion was price related.

\section{Lender Borrower}

Loan:

$\square \square$

Loan Repayment:

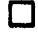

DOther Transfer of Tiue (Specify):

Does this transaction involve intracompany transfer of material? $\square$ Yes $\square \mathrm{No}_{0}$

E. Origin and Destination: Give counury of origin and of destination for the material specified under licm D above.

\begin{tabular}{|c|c|c|c|c|c|c|c|}
\hline \multirow{2}{*}{$\begin{array}{l}\text { Informution } \\
\text { Requested }\end{array}$} & \multirow{2}{*}{2} & \multicolumn{2}{|c|}{$\begin{array}{l}\text { UsOs or } \\
\text { Mined Ond }\end{array}$} & \multicolumn{2}{|c|}{$\begin{array}{l}\text { Natural UPa and } \\
\text { Conversion Service }\end{array}$} & \multicolumn{2}{|c|}{$\begin{array}{l}\text { Boriched URG } \\
\text { and SWU }\end{array}$} \\
\hline & & Actual & Puture & Aousal & Puture & Acuin & Tưture \\
\hline \multicolumn{8}{|l|}{ Country where mined: } \\
\hline Conversion service country: & $\therefore$ & & Ali & & & & \\
\hline Enrichment service country: & $\cdots$ & 3 & 13 & We & 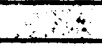 & & \\
\hline Country of destination: & 3 & & & & & & \\
\hline
\end{tabular}

2. Custody Transactions: (Involving

\section{Type of Material Covered Under this}

Contract: Mark box or boxes to show material sent and/or received.

$\square$ Storage/holding Agreement

DOther Custody Transaction (Specify):
G. Pricing Mechanism:

$\square$ 1. Contract specificd: $\square$ Fixed price

$\square$ 2. Market-price related:
a. Selllement mode:
b. Floor type:
$\square$ External indicator
$\square$ Fixed noor price
$\square$ Cost floor
$\square$ Negotiated
$\square$ Escalated noor
$\square$ No floor

$\square$ Yes

c. Ceiling price:

$\square$ Base-price escalated

13. Other (Explain pricing mechanism(s) under Comments on Page 9.)
1. Contract Options: At whose option can the following lake place? Buyer's Seller's

1. Optional quantitios

2. Additional quantities

3. Cancel some or all deliverics

4. Substitution of matcrial

S. Change in delivery date(s)

H. Status of Litigation: 1 . In litigation on December 31, 1993: $\square$ Yes $\square$ No.

\begin{tabular}{|c|c|c|c|c|c|c|c|c|}
\hline \multirow{4}{*}{ 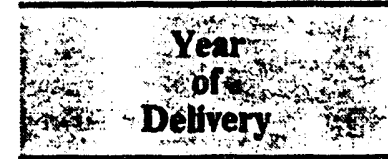 } & \multirow{3}{*}{\multicolumn{2}{|c|}{$\begin{array}{l}\text { J. Quantity } \\
\text { (Thousand pounds } \\
\mathrm{U}_{3} \mathrm{O}_{8} \text { equivalent) }\end{array}$}} & \multicolumn{6}{|c|}{ (S per pound U308) } \\
\hline & & & \multirow{2}{*}{\multicolumn{3}{|c|}{ K. Market-Price Procurement }} & \multirow{2}{*}{\multicolumn{2}{|c|}{ 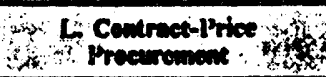 }} & \multirow{3}{*}{$\begin{array}{l}\text { Par other } \\
\text { Procumement }\end{array}$} \\
\hline & & & \multirow{2}{*}{ Semied } & & & & & \\
\hline & ${ }^{x}$ Firm & Optional. & & Encelned & Nenisecelated & Exelined ? & Nen-Esealatied & \\
\hline 1993 Settled Price $\mathrm{n}^{2}$ & & nin & & & & & & \\
\hline 1993 Not Settlod Price & & and & & & & & & \\
\hline 1994 Settled Price & & 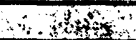 & & & & & & \\
\hline 1994 Not Settled Price & & & & & & & & \\
\hline 1995 os & & & & & & & & \\
\hline 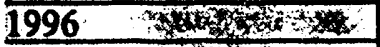 & & & & & & & & \\
\hline 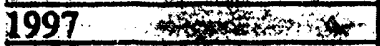 & & & & & & & & \\
\hline 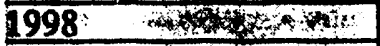 & & & & & & & & \\
\hline$+40 \times 4 \times 6 \%$ & & & & & & & & \\
\hline $3 x+3 x+140$ & & & & & & & & \\
\hline 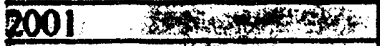 & & & & & & & & \\
\hline 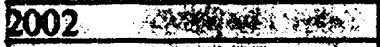 & & & & & & & & \\
\hline 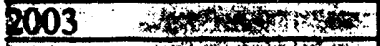 & & & & & & & & \\
\hline 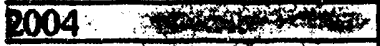 & & & & & & & & \\
\hline 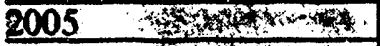 & & & & & & & & \\
\hline 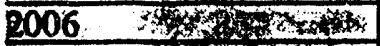 & & & & & & & & \\
\hline $6007 \quad 30 \times 45$ & & & & & & & & \\
\hline 2008 and bejónds & & & & & & & & \\
\hline
\end{tabular}


ITEM 2: URANIUM INVENTORIES: Include matcrial reported in Item 1.C.2 above that belongs to a foreign company and was stored at your site(s) at ycar end.

\begin{tabular}{|c|c|c|c|c|}
\hline \multirow{3}{*}{ 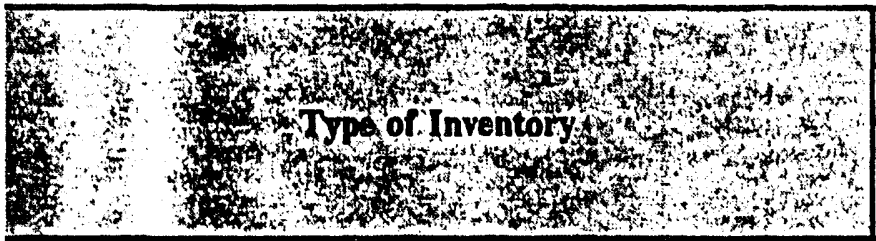 } & \multicolumn{4}{|c|}{ Quantity (1000 lbs of $\mathrm{U}_{3} \mathrm{O}_{8}$ Equivalent) } \\
\hline & \multicolumn{2}{|c|}{ Domestic-Origin } & \multicolumn{2}{|c|}{ Forelgn Origin $^{2}$} \\
\hline & $\begin{array}{c}\text { Year-end } \\
1992\end{array}$ & $\begin{array}{l}\text { Year-end } \\
1993\end{array}$ & $\begin{array}{l}\text { Year-end } \\
1992\end{array}$ & HYear-end \\
\hline 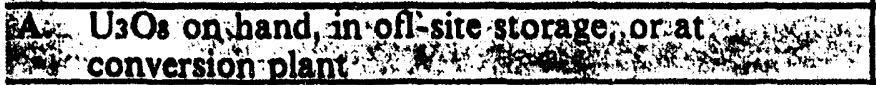 & & & & \\
\hline 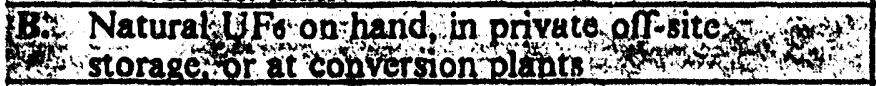 & & & & \\
\hline $\begin{array}{l}\text { G1. Natural UFo at enrichment suppliers } \\
\text { (Exclude:amounts hold under usage agreements) }\end{array}$ & & & & \\
\hline C2 Enriched UF6at enrichment suppliers & & & & \\
\hline D. Enriched UFo on hand and/or in private storage & & & & \\
\hline $\begin{array}{l}\text { Fabricated fucl not inserted into a reactor, on } \\
\text { hand, and/or in private stora se }\end{array}$ & & & & \\
\hline $\begin{array}{l}\text { Natural UF6 your company has delivered to } \\
\text { DOE/USEC under usage a oreements }\end{array}$ & & & & \\
\hline 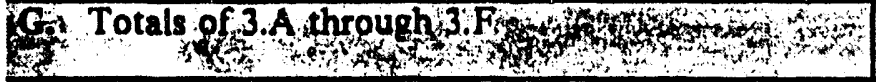 & & & & \\
\hline
\end{tabular}

ITEM 3: UTILITY URANIUM INVENTORY POLICY: Does your company have an inventory policy on any form of uranium? $\square$ Yes $\square$ No (If Yes, provide the following data)

\begin{tabular}{|c|c|c|}
\hline \multirow{2}{*}{$\begin{array}{l}\text { Why } \\
\text { Type of thventory }\end{array}$} & \multicolumn{2}{|c|}{ 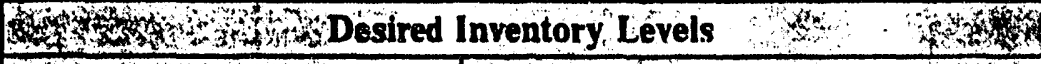 } \\
\hline & Months of forwand coverage & Thousand pounds $\mathrm{U}_{3} \mathrm{O}_{8}$ equivalent \\
\hline \multicolumn{3}{|l|}{$\mathrm{U}_{3} \mathrm{O}_{8}$} \\
\hline \multicolumn{3}{|l|}{ Natural UF6 } \\
\hline Enriched UF 6 & & \\
\hline Fabricated Fucl & & \\
\hline
\end{tabular}

\section{ITEM 4: ACTUAL ENRICHMENT FEED DELIVERIES IN THE SURVEY YEAR}

\begin{tabular}{|c|c|c|}
\hline 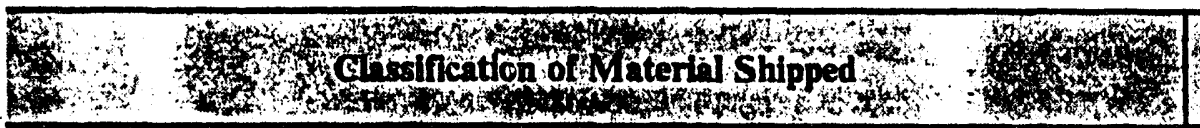 & $\begin{array}{l}\text { Quantity } \\
\text { (1000 lbs U } \mathrm{U}_{3} \\
\text { Equivalent) }\end{array}$ & $\begin{array}{l}\text { Cumenistis } \\
\text { untry } \\
\text { unts }\end{array}$ \\
\hline Shipment of U.Sidorigin material to DOE/USEC enrichment & & \\
\hline B* Shipment of foreien origin material to DOEJUSEC enrichment plants: & & (1) \\
\hline 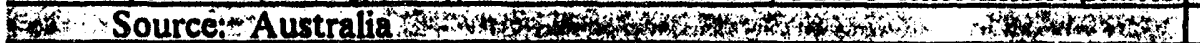 & & (x) \\
\hline 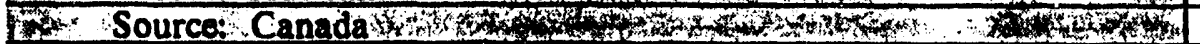 & & $\sqrt{3}$ \\
\hline 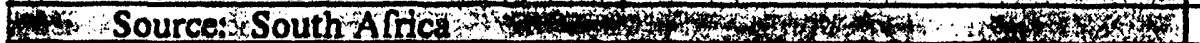 & & 20140 \\
\hline Source Other (Please Specify)get & & E. \\
\hline $\begin{array}{l}\text { Shipment } 3 \text { of } \\
\text { (including sec }\end{array}$ & & \\
\hline 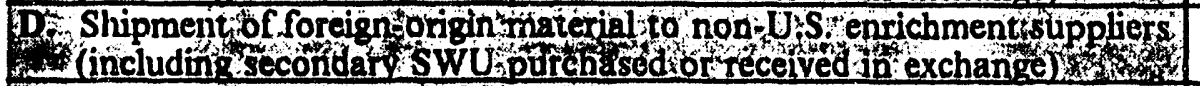 & & \\
\hline St & 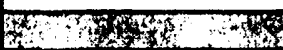 & 20.6 \\
\hline $\mathrm{KU}_{3} \mathrm{O}_{8}$ & & \\
\hline Total (AX+ B & & \\
\hline
\end{tabular}


ITEM 5: PROJECTED ENRICHMENT FEED DELIVERIES AND UNFILLED MARKET REQUIREMENTS

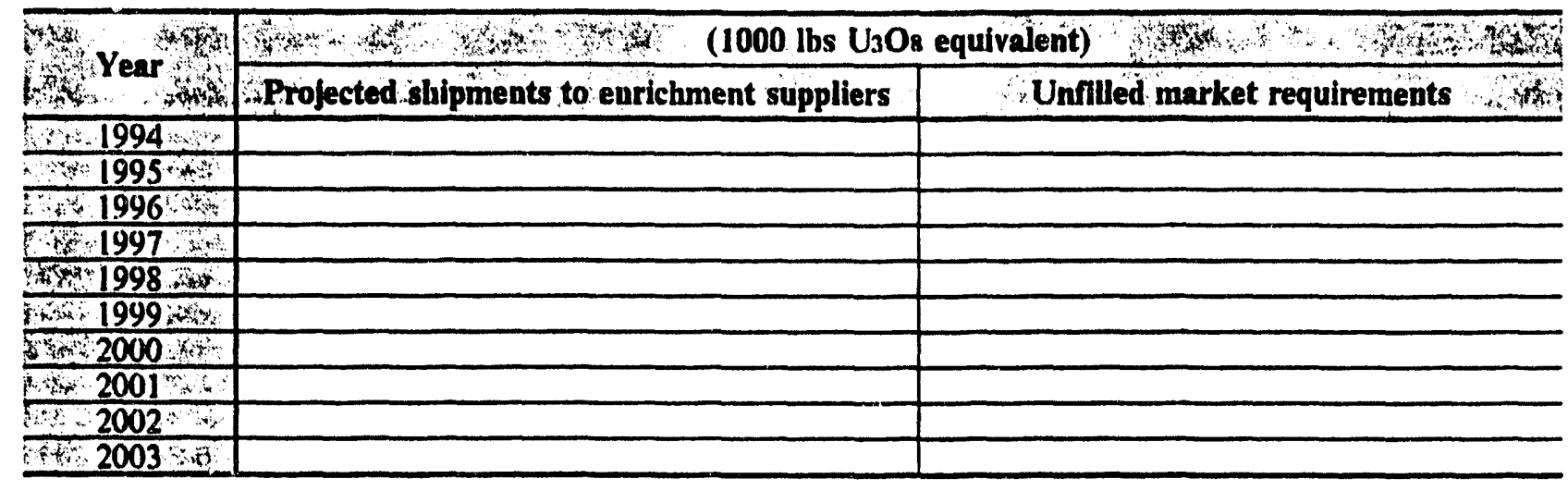

\section{ITEM 6: URANIUM USED IN FUEL ASSEMBLIES IN THE SURVEY YEAR}

\begin{tabular}{|c|c|c|c|c|}
\hline \multirow{3}{*}{$\begin{array}{l}\text { Utilities Onfy Report only the total of unirradiated } \\
\text { uranium in fuel assemblics loaded into reactors } \\
\text { during thosurvey Year and during the prior year } \\
\text { byorigin \&Do not include uranium removed from } \\
\text { reactors that subsequently will be rcloaded. }\end{array}$} & \multicolumn{4}{|c|}{ Quantity ( 1000 lbs of U3O8 Equivalent) } \\
\hline & \multicolumn{2}{|c|}{ Domestic-Origin } & \multicolumn{2}{|c|}{ Forelgn-Origin } \\
\hline & $\begin{array}{c}\text { Year-end } \\
1992\end{array}$ & $\begin{array}{l}\text { Year-and } \\
1993\end{array}$ & $\begin{array}{c}\text { Year-end } \\
1992\end{array}$ & Year-end \\
\hline 2 & & & & \\
\hline
\end{tabular}

\section{ITEM 7: ENRICHMENT SERVICES PURCHASED BY UTILITIES}

\begin{tabular}{|c|c|c|c|}
\hline Sellers Name & $\begin{array}{l}\text { Country Location } \\
\text { of Seller }\end{array}$ & $\begin{array}{l}\text { Quantity } \\
\text { (Separative Work Units) }\end{array}$ & $\begin{array}{l}\text { Scheduled } \\
\text { Delivery Date }\end{array}$ \\
\hline & & & \\
\hline & & & \\
\hline
\end{tabular}

COMMENTS FOR SCHEDULE B 


\title{
Appendix E
}

\author{
U.S. Customary Units \\ of Measurement, \\ International System \\ of Units (SI), and \\ Selected Data Tables \\ in SI Metric Units
}

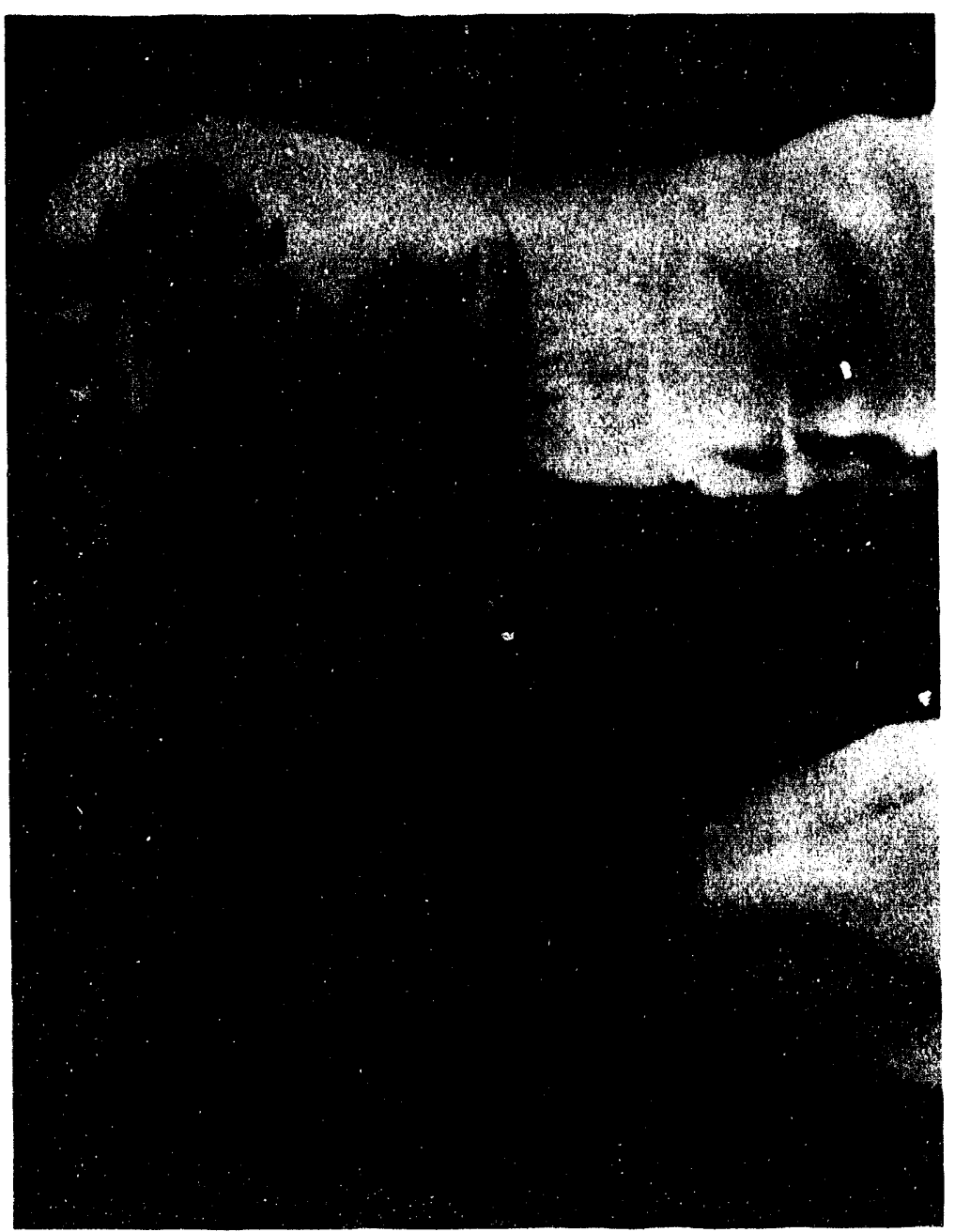

After uranium has been enriched, the uranium hexaffuoride (UF, is processed into uranium oxide (UO) powder, which is then formed into half-inch long pellets. The hard, ceramic-like pellets are loaded into long metal (zirconium alloy) tubes to form fuel rods. Fuel rods are grouped together to form tuel assemblies. Fuel assemblies form the reactor core of a large nuclear power plant. Each fuel pellet can generate as much electricty as approximately 1,600 pounds of coal. 


\section{Appendix E}

\section{U.S. Customary Units of Measurement, International System of Units (SI), and Selected Data Tables in SI Metric Units}

Standard Factors for interconversion between U.S. customary units and the International System of Units (SI) are shown in Table E1. These factors are provided as a coherent and consistent set of units for the convenience of the reader in making conversions between U.S. and metric units of measure for data published in this report. Conversion factors are provided only for the U.S. units of measurcment quoted in this report.

Table E1. Conversion Factors for U.S. Customary Units and SI Metric Units of Measurement

To convert from:

To:

Area

\begin{tabular}{|c|c|c|}
\hline acre & meter $\left(m^{2}\right)$ & 4,047 \\
\hline $\begin{array}{l}\text { foot }(f i) \\
\text { yard }(y d)\end{array}$ & $\begin{array}{l}\text { meter }(m) \\
\text { meter }(m)\end{array}$ & $\begin{array}{l}0.3048 \\
0.9144\end{array}$ \\
\hline \multicolumn{3}{|c|}{ Mese } \\
\hline $\begin{array}{l}\text { pound-avolidupols (lb avdp) } \\
\text { pound-avolrdupols } \mathrm{U}_{3} \mathrm{O}_{1}^{\mathrm{b}} \\
\text { ton, short }(2,000 \mathrm{lb})\end{array}$ & $\begin{array}{l}\text { kllogram (kg) } \\
\text { klogram U } \\
\text { metric ton (U) }\end{array}$ & $\begin{array}{l}0.4536 \\
0.3847 \\
0.9072 \\
\end{array}$ \\
\hline
\end{tabular}

\footnotetext{
"An asteribk after the last dight of the factor indicates that the conversion factor bexact and that all subeequent diglts are zero. All other conversion factors are rounded to four aignificant diglts.

The fector of 1 pound $U_{3} O_{0} \approx 0.8480$ pounds $U$ was used in this conversion.

8ource: Table E1 is pattemed after Table 3, "Conversion Factors for SI Metric Units and U.S. Customary Units of Measurement," in S.M. Long and A.M. Oreilana,

The Metric Syetem," In Suggestions to Authors of the Reports of the United States Geological Survey, Sixth Edition, U.8. Government Printing Office (Washington, DC, 1978) Pp. 182-186.
} 


\section{Forward Cost and Average Price Conversions}

The forward-cost categories of \$US80 through \$US260 per pound $U$ shown on Table E3 to report uranium reserves quantities were converted from units of "\$ per pound $\mathrm{U}_{3} \mathrm{O}_{8}$ " to " $\$$ per kilogram U" by multiplying by the standard factor of 2.6 and rounding the results to the nearest multiple of \$US10. The "Averages of Reported Prices" shown on Tables E7 and E9 were derived by applying that same factor to convert to "dollars per kilogram U." These averages were calculated from data reported in Item 1, "Contract," of Schedule B, "Uranium Marketing Activities," Form EIA-858, for the survey year.

\section{Selected Tables Converted to SI Metric Values}

Nine principal tables of data from the Uranium Industry Annual 1993 (UIA) converted to equivalent metric values are shown on the following pages. The crosswalk given below shows the correlation between the tables of metric values and their corresponding tables in U.S. customary units in the main body of the UIA.
Appendix E Table Number
UIA Chapter and Table Number

\begin{tabular}{|c|c|}
\hline 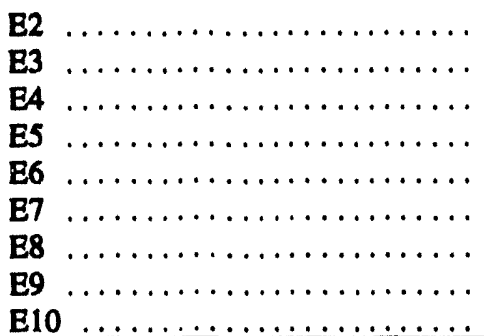 & $\begin{array}{l}\text { Chapter 1, Table } 3 \\
\text { Chapter 1, Table } 9 \\
\text { Chapter 1, Table } 12 \\
\text { Chapter 1, Table } 17 \\
\text { Chapter 2, Table } 23 \\
\text { Chapter 2, Table } 28 \\
\text { Chapter 2, Table } 29 \\
\text { Chapter 2, Table } 34 \\
\text { Chapter 2, Table } 40\end{array}$ \\
\hline
\end{tabular}


Table E2. U.S. Uranlum Drilling by Type of Drilling, 1966-1993

\begin{tabular}{|c|c|c|c|c|c|c|c|c|}
\hline \multirow[b]{2}{*}{$\because$ rean(0) } & \multicolumn{4}{|c|}{ Exploretion Orlating } & \multicolumn{4}{|c|}{ Dovelopmemt Drilling" } \\
\hline & $\begin{array}{l}\text { Number of } \\
\text { Holve Drillod }\end{array}$ & Minion Metere" & $\begin{array}{c}\text { Coet } \\
\text { (miluton dot } \\
\text { laros }\end{array}$ & $\begin{array}{l}\text { Averege Coet } \\
\text { (dollare per } \\
\text { motor)" }\end{array}$ & $\begin{array}{l}\text { Number of } \\
\text { Holes Drillod }\end{array}$ & Mililon Moters" & $\begin{array}{l}\text { Coot } \\
\text { (million dot } \\
\text { lares) }\end{array}$ & $\begin{array}{l}\text { Average Coet } \\
\text { (dollare per } \\
\text { moter)" }\end{array}$ \\
\hline $1908-1973$ & 220,721 & 27.s8 & 124.62 & 4.65 & 124,393 & 8.46 & 28.68 & - \\
\hline 1974 & 27,400 & 4.40 & 34.96 & 7.70 & 12,300 & 2.06 & 9.81 & 4.71 \\
\hline 1975 & 34,286 & 4.78 & 51.22 & 10.80 & 21,000 & 2.87 & 21.80 & 7.39 \\
\hline 1970 & 40,400 & 6.21 & 70.70 & 11.30 & 27,201 & 4.40 & 36.30 & 8.7 \\
\hline $18 n$ & 82,597 & 8.62 & 90.40 & 11.66 & 30,868 & 6.37 & 65.60 & 10.35 \\
\hline 1978 & 75,098 & 8.82 & 113.30 & 12.84 & 29,288 & 5.84 & 86.40 & 9.60 \\
\hline 1970 & 60,467 & 8.88 & 119.60 & 19.80 & 30,191 & 3.97 & 49.40 & 10.86 \\
\hline 1900 & 39,607 & 8.97 & 04.80 & 18.87 & 20,188 & 2.62 & 30.90 & 11.80 \\
\hline 1881 & 17,761 & 3.31 & 80.43 & 17.03 & 86,673 & 1.02 & 11.47 & 11.23 \\
\hline 1092 & 6,806 & 1.20 & 20.84 & 16.24 & 3,002 & 0.34 & 6.90 & 20.03 \\
\hline 1803 & 4,287 & 0.64 & 10.60 & 16.64 & 3,011 & 0.33 & 3.84 & 11.57 \\
\hline 1984 & 4,786 & 0.00 & 10.53 & 15.29 & 723 & 0.00 & 1.32 & 14.03 \\
\hline 1986 & 2,877 & 0.43 & 8.14 & 11.88 & 72 & 0.10 & 0.39 & 3.76 \\
\hline 1000 & 1,908 & 0.34 & 6.40 & 19.00 & 1,846 & 0.30 & 1.36 & 4.57 \\
\hline 1997 & 1,820 & 0.34 & 5.80 & 17.44 & 1,094 & 0.26 & 1.08 & 4.04 \\
\hline 1888 & 2,000 & 0.30 & 6.44 & 16.51 & 3,178 & 0.63 & 3.26 & 6.18 \\
\hline 1600 & 2,087 & 0.44 & 8.82 & 13.36 & 1,760 & 0.24 & 3.12 & 12.80 \\
\hline 1000 & 1,807 & 0.27 & 3.21 & 12.11 & 1,800 & 0.25 & 5.96 & 24.10 \\
\hline 1901 & 1,024 & 0.30 & 2.83 & 9.67 & 1,573 & 0.28 & 8.11 & 30.58 \\
\hline 18002 & 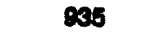 & 0.17 & 1.27 & 7.44 & 893 & 0.16 & 1.16 & 7.61 \\
\hline 1000 & 365 & 0.07 & 0.98 & 14.46 & 1,066 & 0.27 & 4.75 & 17.61 \\
\hline
\end{tabular}

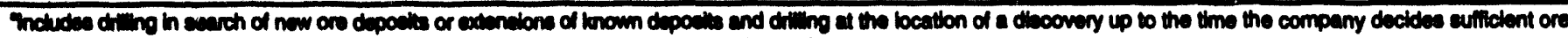

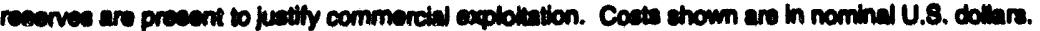

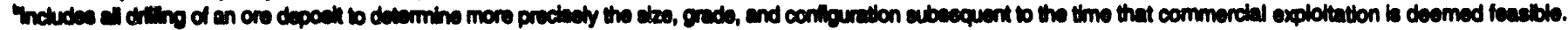
Cocts thoum are in nominal U.8. Dollare.

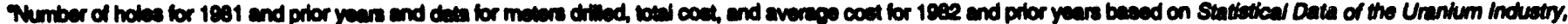
QVO-100(e8)(Jenuary 1, 1983). Coet thown are in nominal, U.8. dollare.

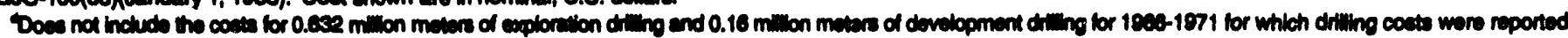

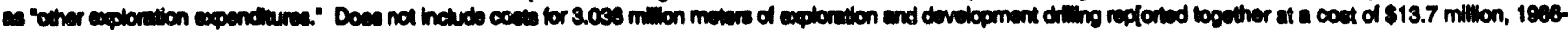
1972.

This high value in altributable primarty to the large percentage of botal expendtures for development drilling in 1982 attributable to one company.

- = Not appolicablo

Now: Avernos coet per meter ahown here may not equal quotionts obtained with independenty rounded numerator and denominator.

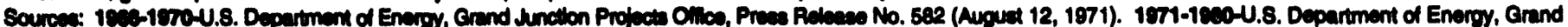

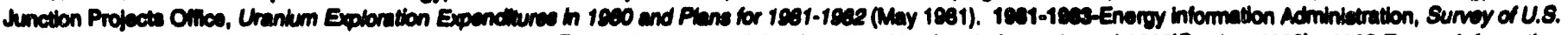

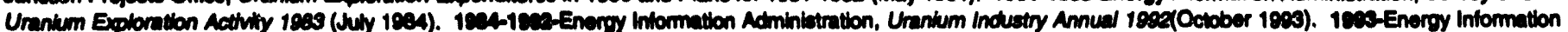

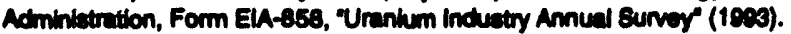


Table E3. Changes In U.S. Uranlum by Forward-Cost Category, 1993 (Thousand Metric Tons U)

\begin{tabular}{|c|c|c|c|}
\hline \multirow[b]{2}{*}{ Yor End Reenve end Chenge } & \multicolumn{3}{|c|}{ Fonward-Cost Caterory } \\
\hline & $\begin{array}{c}\$ U S 80 \\
\text { per kilogram U }\end{array}$ & $\begin{array}{c}\text { \$US130 } \\
\text { per kllogram U }\end{array}$ & $\begin{array}{c}\$ U S 260 \\
\text { per kllogram U }\end{array}$ \\
\hline Reserves at the End of $1892 \ldots \ldots \ldots \ldots \ldots \ldots$ & 114 & 369 & 586 \\
\hline \multicolumn{4}{|l|}{ Pesvaluations of Reserves in 1993} \\
\hline Additions $\ldots \ldots \ldots \ldots \ldots \ldots \ldots \ldots \ldots \ldots \ldots \ldots \ldots$ & 2 & 1 & 1 \\
\hline Subtrections $\ldots \ldots \ldots \ldots \ldots \ldots \ldots \ldots \ldots \ldots \ldots \ldots$ & (2) & (2) & (3) \\
\hline Depletion (Production and Erosion) in 1993. & (1) & (2) & (3) \\
\hline Reeerves at the End of 1893 . & 112 & 366 & 581 \\
\hline
\end{tabular}

Notes: Tothls may not equal sum of components because of independent rounding. No reserves ovaluations for new uranium properties are included in the estimates d U.8. resenwe made during 1983. Unanium reserves that could be recovered as a byproduct of phosphate and copper mining are not included in this table. Reserves vilues in formurd-cost categories are cumulative: that is, the quantily at each level of forward cost includes all reserves at the lower costs.

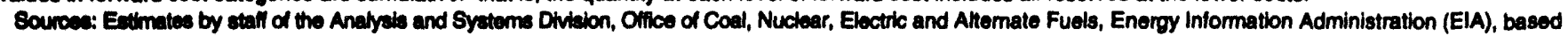
on U.S. Department of Energy, Grand Junction Projects Ofilce data files and Form EIA-858, Uranium Industry Annual Survey" (1993).

Table E4. U.S. Uranlum Mine Production of Uranium by Mining Method, 1981 - 1992 (Thousand Metric Tons U)

\begin{tabular}{|c|c|c|c|c|c|c|c|c|c|c|c|c|c|}
\hline Mlat Mchod & 1881 & 1892 & 1889 & 1884 & 1885 & 1888 & 1897 & 1808 & 1889 & 1880 & 1991 & 1992 & 1993 \\
\hline $\begin{array}{l}\text { Underroround } \ldots \ldots \ldots \\
\text { Percent of Total } \ldots \ldots\end{array}$ & $\begin{array}{r}6.5 \\
46.4\end{array}$ & $\begin{array}{r}4.8 \\
53.4\end{array}$ & (a) & $\begin{array}{r}1.9 \\
49.0\end{array}$ & $\begin{array}{r}1.7 \\
52.3\end{array}$ & $\begin{array}{r}2.5 \\
77.8\end{array}$ & $\begin{array}{r}1.9 \\
81.7\end{array}$ & $\begin{array}{r}2.1 \\
56.8\end{array}$ & $\begin{array}{r}2.0 \\
54.4\end{array}$ & $\begin{array}{l}W \\
W\end{array}$ & $\begin{array}{l}W \\
W\end{array}$ & $\begin{array}{l}W \\
W\end{array}$ & 0 \\
\hline 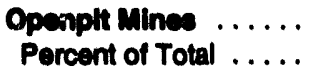 & $\begin{array}{r}5.4 \\
38.3\end{array}$ & $\begin{array}{r}2.9 \\
32.2\end{array}$ & (a) & $\begin{array}{r}1.1 \\
29.0\end{array}$ & $\begin{array}{r}0.8 \\
23.3\end{array}$ & $\begin{array}{l}w \\
W\end{array}$ & $\begin{array}{l}W \\
W\end{array}$ & $\begin{array}{l}W \\
W\end{array}$ & $\begin{array}{l}W \\
W\end{array}$ & $\begin{array}{r}0.7 \\
32.0\end{array}$ & $\begin{array}{r}1.0 \\
48.8\end{array}$ & $\begin{array}{l}w \\
W\end{array}$ & 0 \\
\hline 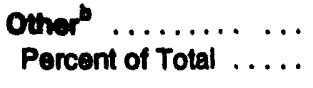 & $\begin{array}{r}2.2 \\
15.3\end{array}$ & $\begin{array}{r}1.3 \\
14.4\end{array}$ & $\begin{array}{r}1.9 \\
20.9\end{array}$ & $\begin{array}{r}0.8 \\
22.0\end{array}$ & $\begin{array}{r}0.8 \\
24.4\end{array}$ & $\begin{array}{r}0.7 \\
22.2\end{array}$ & $\begin{array}{r}0.4 \\
18.3\end{array}$ & $\begin{array}{r}1.6 \\
43.2\end{array}$ & $\begin{array}{r}1.7 \\
45.6\end{array}$ & $\begin{array}{r}1.5 \\
68.0\end{array}$ & $\begin{array}{r}1.0 \\
51.2\end{array}$ & $\begin{array}{r}0.4 \\
100.0\end{array}$ & $\begin{array}{r}0.8 \\
100.0\end{array}$ \\
\hline Total $\ldots \ldots \ldots \ldots$ & 14.1 & 9.1 & 9.0 & 3.8 & 3.3 & 3.2 & 2.3 & 3.7 & 3.7 & 2.3 & 2.0 & 0.4 & 0.8 \\
\hline $\begin{array}{l}\text { Percent Change trom } \\
\text { Prior Year . . . . . . . . }\end{array}$ & $\cdots$ & -35.6 & -0.4 & -57.4 & -14.0 & -3.5 & -27.7 & 58.3 & 2.1 & -39.2 & -11.8 & -80.7 & 105.1 \\
\hline
\end{tabular}

For 1983, openpli plus underground mine production was 7.2 thousend motric tons $U$, or 79.1 percent.

"For 1978-1984, the "Other" category inctudes production from in situ leach, heap leach, mine water, and low-grade stockplles. For 1985 the "Other" includes production from in situ leach, mine water, and water-treatment plant solutions. For 1986 through 1889, the "Other" includes production from openpit, in situ lach, heap leach, mine water, and water-treatment plant solutions. For 1990 and 1991, the "Other" includes production from underground, in sttu leach, heap lech (1890), mine water, water-treatment plant sohtions (1990), and restoration. For 1992, the "Other" includes production from underground and in situ leach mines, uranium bearing water from mine workings and tallings ponds, and restoration. For 1993, the "Other includes production form in situ leach mines and unanium bearing water from restoration.

$-=$ Not applicable.

$W=$ Whitheld to evoid disclosure of company-specific data. The data are included in the total for "Other."

Notes: Totals may not equal sum of components because of independent rounding. Percentages were calculated using unrounded data.

Sounce: 1976-18e-U.S. Department of Energy, Grand Junction Projects Office, Statistical Data of the Uranium Incustry (January 1983). 18as-Estimated by thaf of the Analyals and Syeteme Division, Office of Cosl, Nuclear, Electric and Altemate Fuels, Energy Information Administration, from U.S. Department of Energy, Grand Junction Projects Office data files. 1994-19e2_Energy Information Administration, Uranium Industry Annual 1992 (October 1993). 1693 Eneroy information Administration, Form ElA-858, Uranium Industry Annual Survey" (1993). 
Table E5. U.S. Uranlum Processing Operations, 1983-1993

\begin{tabular}{|c|c|c|c|c|c|c|c|c|c|c|c|}
\hline Procesain. Operntion & 1883 & 1824 & 1898 & 1808 & 1997 & 1989 & 1989 & 1800 & 1991 & 1892 & 1993 \\
\hline \multicolumn{12}{|l|}{ Ore Fed to Process" } \\
\hline (thousand motric tons $U$ ) & 5,375 & 3,915 & 1,628 & 1,187 & 1,307 & 1,101 & 1,120 & 655 & 580 & 232 & 0 \\
\hline$(\text { orado) })^{b} \ldots \ldots \ldots$ & 0.128 & 0.112 & 0.181 & 0.388 & 0.284 & 0.288 & 0.323 & 0.293 & 0.198 & 0.229 & - \\
\hline (thousand motric tons U) & 5.839 & 3.705 & 2.225 & 3.378 & 3.151 & 2.692 & 3.088 & 1.628 & 0.973 & 0.460 & 0 \\
\hline \multicolumn{12}{|l|}{ Other Mill Fead } \\
\hline (thousand motrlc tons $U$ ) & 0.220 & 0.208 & 0.288 & 0.100 & 0.182 & 0.185 & 0.165 & 0.186 & 0.069 & 0.070 & 0.016 \\
\hline \multicolumn{12}{|l|}{ Total Mill Feed } \\
\hline (thousand motric tons U) & 6.089 & 3.811 & 2.514 & 3.478 & 3.333 & 2.887 & 3.233 & 1.812 & 1.042 & 0.520 & 0.016 \\
\hline \multicolumn{12}{|l|}{ In-Process Inventory Change } \\
\hline (thousand motric tons $U$ ) & -0.108 & 0.018 & 0.079 & 0.025 & -0.081 & 0.052 & -0.080 & -0.094 & -0.047 & 0.010 & 0.004 \\
\hline \multicolumn{12}{|l|}{$\begin{array}{l}\text { Concentrate Production } \\
\text { (thousand metric tons U) }\end{array}$} \\
\hline Theoretical Production ${ }^{d}$ & 6.167 & 3.892 & 2.434 & 3.508 & 3.413 & 2.834 & 3.323 & 1.808 & 1.089 & 0.530 & 0.012 \\
\hline Conventional Milling . . . & 5.969 & 3.700 & 2.340 & 3.408 & 3.283 & 2.708 & 3.144 & 1.788 & 1.003 & 0.523 & 0.012 \\
\hline \multicolumn{12}{|l|}{ Tallings Loss } \\
\hline Unaccountables $\ldots \ldots$ & 0.198 & 0.180 & 0.094 & 0.098 & 0.130 & 0.129 & 0.179 & 0.119 & 0.085 & 0.007 & 0.001 \\
\hline \multicolumn{12}{|l|}{ Recovery From Mill Feed } \\
\hline (percent) $\ldots \ldots \ldots \ldots$ & 88.8 & 85.1 & 88.1 & 97.2 & 88.2 & 95.5 & 84.6 & 93.8 & 92.2 & 88.7 & - \\
\hline Other Processing $\ldots$ & 2.169 & 2.022 & 2.012 & 1.780 & 1.714 & 2.345 & 2.178 & 1.680 & 2.058 & 1.649 & 1.168 \\
\hline Total Production ...... & 8.138 & '5.724 & 14.352 & '5.195 & 14.997 & 5.050 & 5.322 & 3.418 & 3.059 & 2.171 & 1.178 \\
\hline \multicolumn{12}{|l|}{ Concentrate Shipments } \\
\hline (thousand motric tons U) & 7.599 & 5.966 & 4.523 & 4.003 & 4.446 & 4.820 & 5.696 & 4.984 & 3.245 & 2.686 & 1.298 \\
\hline
\end{tabular}

"Uranlum ore "ed to procees" in any year can include: ore mined and ehipped to a mill during the came year, ore that was mined during a pribr year and later shipped from mine-site stockplles, and/or ore obtained from drawdowns of stockpiles maintained at a mill site.

Wolghted average percent.

Includes uranium from low-grade ore, mine water, tallings water, and heap leaching, excepp as footnoted below.

At 100-percent recovery.

Uranium concentrate production from in stu lesching and ea a byproduct of other proceseing. The totals for 1986 and following years include uranium concentrato recovered from reclamation and mine water at ecmo mill that did not report proceseing of uranium ore for those years.

Total does not include uranlum concentrate production from pillot projects or other rescarch project sources.

$=$ Not applicable

Note: Totals may not equal sum of components because of independent rounding.

Sources: 1883-Calculated by Energy Information Adminietration, Office of Coal, Nuclear, Electric and Altemate Fuele, from U.S. Department of Energy, Grand Junction Projects Office data filos. 1994-16e2-Energy Intormation Administration, Unanium Industry Avnual 1992 (October 1993 ). 19e3-Energy information Administration, Form ElA-858, Uranlum Industry Annual Survor" (1893). 
Table E6. Commitments for Dellvery of Uranlum from Suppliers to U.S. Utillties, 1993-2000 and Later (Thousand Metric Tons U Equivalent)

\begin{tabular}{|c|c|c|c|c|c|c|c|c|c|c|}
\hline \multirow[b]{2}{*}{ Yes of Dontrus } & \multicolumn{4}{|c|}{ As of mecuber 31,1022} & \multicolumn{4}{|c|}{ As of Decomber 31, 1003} & \multicolumn{2}{|c|}{$\begin{array}{l}\text { Chanes in Tot from } \\
\text { December 31, 1992, to } \\
\text { December 31, } 1903\end{array}$} \\
\hline & Fim & Osilonel & Totin & Cumitetwe & Fimn & Ootionel & Tond & Cumutative & Total & Cumulative \\
\hline $189 . \ldots \ldots \ldots \ldots$ & 6.8 & 0.3 & 6.9 & 6.9 & 8.0 & 0 & 8.0 & 6.0 & -0.8 & -0.9 \\
\hline $1894 \ldots \ldots \ldots \ldots$ & 5.1 & 12 & 6.3 & 13.2 & $\mathbf{5 . 3}$ & 0.8 & 5.9 & 11.9 & -0.4 & -1.3 \\
\hline $1005 \ldots \ldots \ldots \ldots$ & 5.0 & 1.3 & 6.3 & 19.5 & 4.1 & 0.7 & 4.8 & 16.8 & -1.4 & -2.7 \\
\hline $1898 \ldots \ldots \ldots \ldots$ & 2.4 & 1.3 & 3.7 & 23.2 & 2.2 & 0.6 & 2.8 & 19.8 & -0.8 & 3.8 \\
\hline $1997 \ldots \ldots \ldots \ldots$ & 1.7 & 0.6 & 2.4 & 25.5 & 22 & 0.6 & 2.8 & 22.4 & 0.4 & 3.1 \\
\hline $1998 \ldots \ldots \ldots \ldots$ & 12 & 0.5 & 1.7 & 27.2 & 1.1 & 0.6 & 1.7 & 24.1 & 0.0 & -3.1 \\
\hline $1080 \ldots \ldots \ldots \ldots$ & 0.7 & 0.2 & 0.8 & 28.1 & 0.7 & 0.4 & 1.1 & 25.2 & 0.2 & -2.8 \\
\hline 2000 and Later .... & 1.6 & $c .1$ & 1.7 & $\mathbf{2 9 . 8}$ & 1.6 & 0.3 & 2.0 & 27.2 & 0.3 & -2.6 \\
\hline Teud ......... & 242 & 5.8 & 20 & - & $g \times 2$ & 40 & 272 & - & - & - \\
\hline
\end{tabular}

- = Not eppliedbio.

Note: Totals may not equal sum of components becauee of independient rounding.

Sorince: Enorgy information Adminietration, Form ELA 858 , Uranium Industry Amnual Survey" (1993). 
Table E7. Average of Prices Pald for Purchases by U.S. Utillties from Suppllore, 1882-1893 (Dollars per Kilogram U Equivalent, Thousand Metric Tons Equivalent)

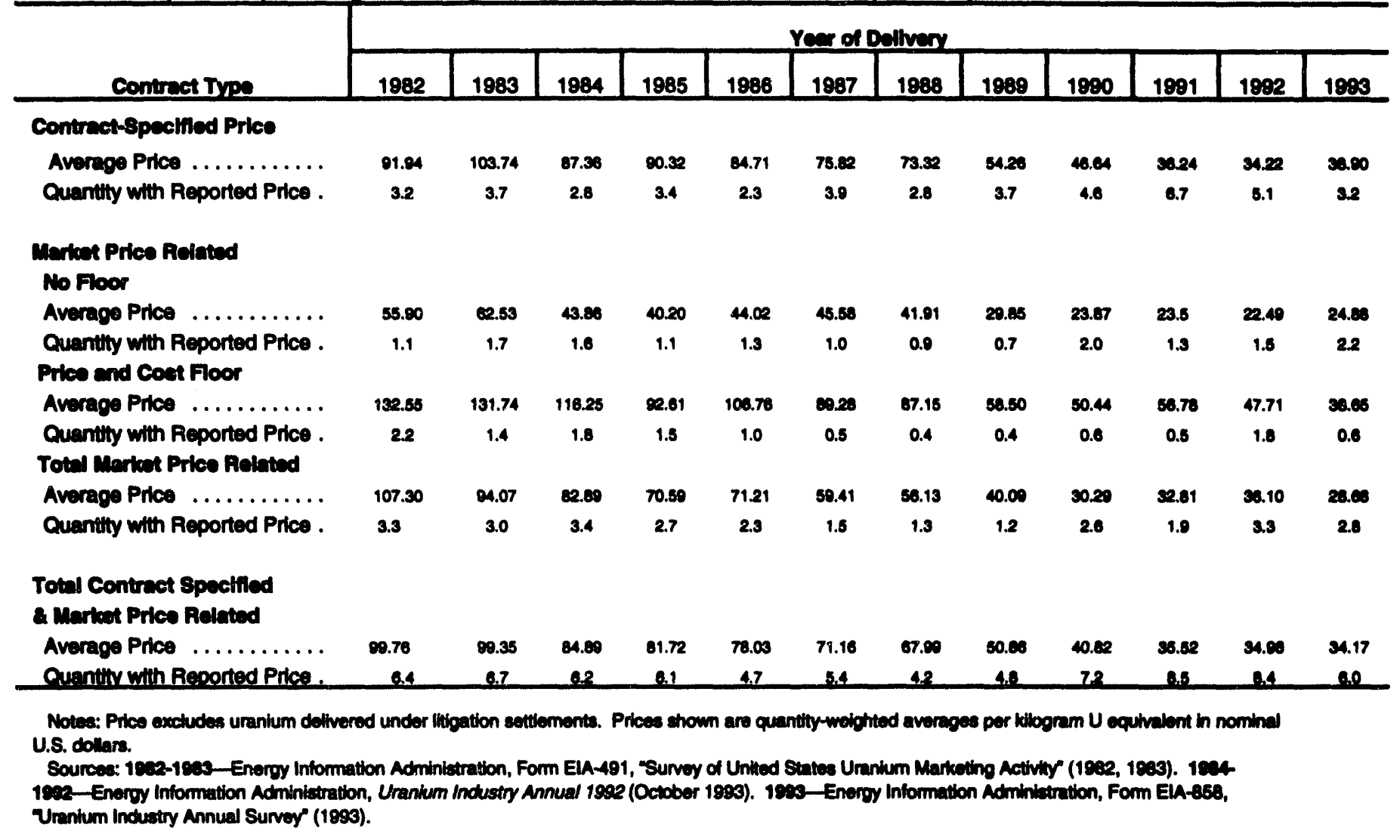


Table E8. Dellveries and Commitments of Uranlum Imports and Exporte by Transaction Typo, 1967 to 2000 and Later (Thousand Metric Tons U Equivalent)

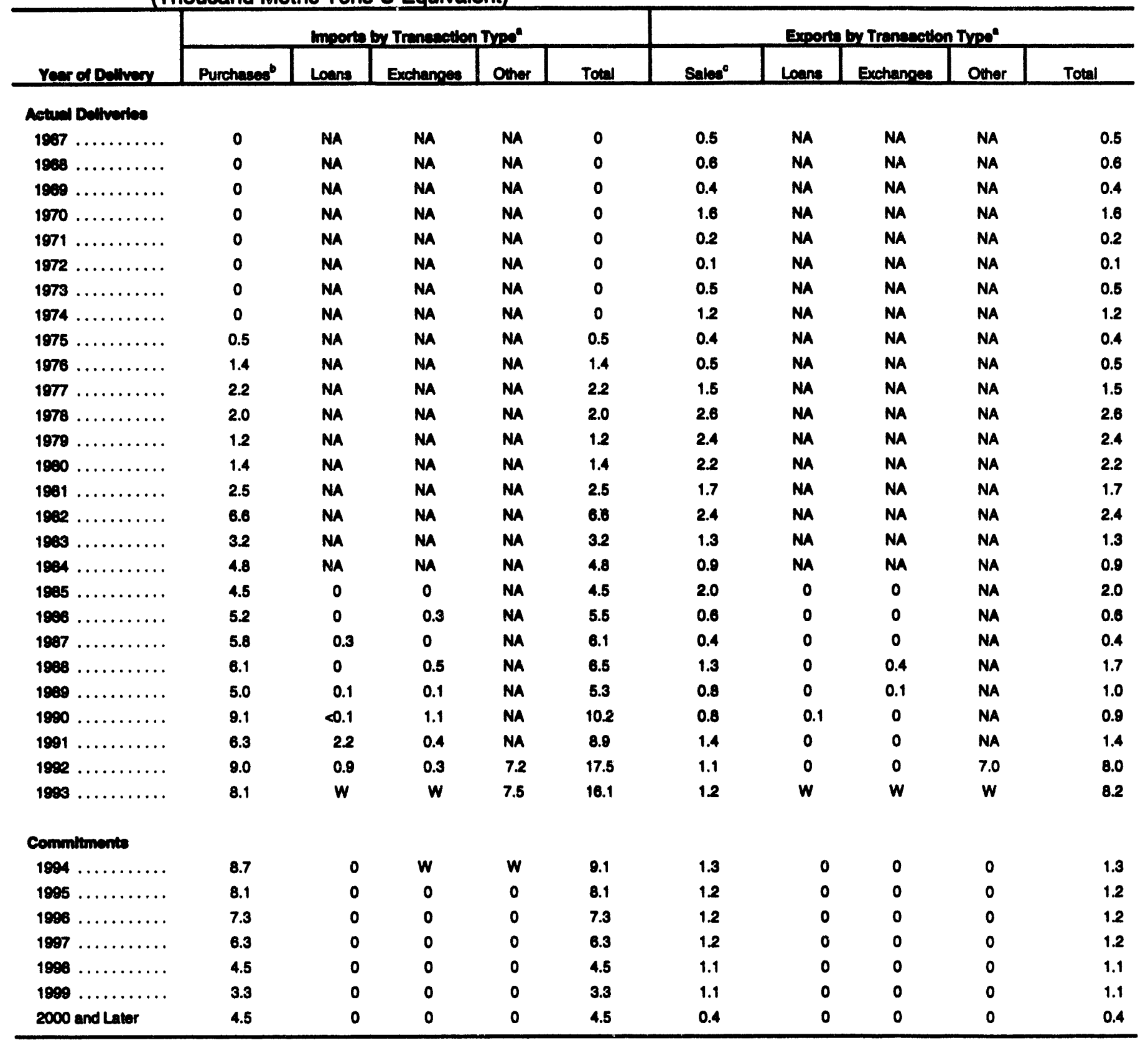

"1ea7-1891-Does not include transactions involving the delwery of uranium matertais imported for custody/atorage siting, conversion, enrichment, andior fuel febrication at U.S. facilities and subsequenthy exported or uranium materiab exported for converion, fuel fabrication, andior enrichment at foreign facllities.

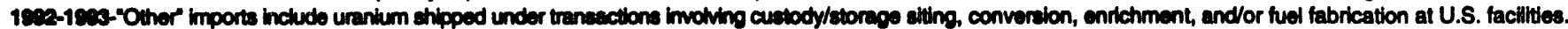
"Other exports include uranium shipped from conversion, enrichment, andlor furl ferication facillies in the United States.

1975-1881, Annual total represents direct purchese of foroign-origin uranium by U.8. companies.

c1887-1881, Annual total represents exports by U.S. uranimm producers only.

$W=$ Withineld to avoid disciosure of individual company data.

NA $=$ Not avallablo.

Note: Totals may not equal sum of components because of independent rouncing.

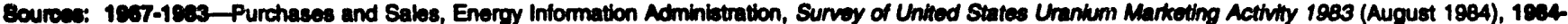

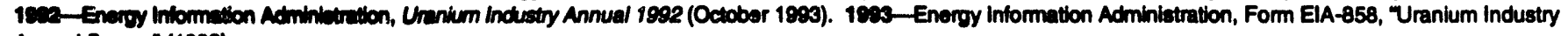
Annual Sunver (109s). 
Table E9. Average of Prices Paid for Imported Uranium Dellvered to U.S. Utilities and Suppllers, 1983-1993

(Dollars per Kilogram U Equivalent, Thousand Metric Tons Equivalent)

\begin{tabular}{|c|c|c|c|c|c|c|c|c|c|c|c|}
\hline Item & 1983 & 1984 & 1885 & 1986 & 1987 & 1988 & 1989 & 1900 & 1901 & 1092 & 1998 \\
\hline Average Price & 68.02 & 56.84 & 52.21 & 52.18 & 49.76 & 49.48 & 43.55 & 32.63 & 40.43 & 29.48 & 27.37 \\
\hline Quantity with Reported Price ... & 3.2 & 4.3 & 4.1 & 4.9 & 5.0 & 5.8 & 5.0 & 9.0 & 6.1 & 8.6 & 8.1 \\
\hline Total Quantity Delivered". . & 3.2 & 4.8 & 4.5 & 5.2 & 5.8 & 6.1 & 5.0 & 9.1 & 6.3 & 9.0 & 8.1 \\
\hline \multicolumn{12}{|l|}{ Percentage of imports Delivered } \\
\hline with Reported Prices. & 100 & 89 & 91 & 95 & 85 & 96 & 100 & 99 & 98 & 96 & 100 \\
\hline
\end{tabular}

The figure shown includes U.S. utility, suppliei, and traderforoker purchases reported as imports of uranium materials into the United States. Uranium materials reported as imports under loan and exchange transactions are excluded.

Notes: Prices shown are quantity-weighted averages per kilogram U equivalent in nominal U.S. dollars. Material quantities are millions of kilogram U equivalent.

Sources: 1893_Energy Information Administration, United States Uranium Marketing Activity 1983 (August 1884). 1894-1892-Energy Information Administration, Uranium Industry Annual 1992 (October 1993). 1993-Energy Information Administration, Form ElA-858, Uranium Industry Annual Survoy" (1980).

Table E10. Commercial and U.S. Government Inventories of Natural and Enriched Uranlum as of End of Year, 1990-1993 (Thousand Metric Tons U Equivalent)

\begin{tabular}{|c|c|c|c|c|}
\hline \multirow[b]{2}{*}{ Type of Uranium Inventory } & \multicolumn{4}{|c|}{ Inventorles at the End of the Year } \\
\hline & 1990 & 1991 & 1992 & 1993 \\
\hline \multicolumn{5}{|l|}{ Utillity Stocks } \\
\hline Natural Uranilum .. & 23.7 & 27.3 & 25.6 & 22.2 \\
\hline Enriched Uranlum". & 15.8 & 10.4 & R9.8 & 8.9 \\
\hline \multicolumn{5}{|l|}{ Domeatic Supplier stoeks } \\
\hline Natural Uranium .. & 8.5 & 7.2 & 7.4 & 7.2 \\
\hline Entiched Uranium". & 1.7 & 0.8 & 2.3 & 1.9 \\
\hline Total Commercial Stocks . . & 49.6 & 45.7 & 45.1 & 40.2 \\
\hline \multicolumn{5}{|l|}{ Covernment-Owned Stocks" } \\
\hline Natural Uranium ........... & 23.0 & 18.0 & 17.6 & 17.9 \\
\hline Enriched Uranium $\ldots \ldots \ldots \ldots \ldots \ldots \ldots \ldots \ldots$ & 12.6 & 14.1 & 8.9 & 10.3 \\
\hline
\end{tabular}

inchudes amounts reported as inventories of UF, at Enrichment Supplier.

Inchudes amounts reported as inventorles by DOE and the Unlied Btates Enrichment Corporation (USEC) for 1993.

A = Rovised data.

Note: Totals may not equal sum of components because of independent rounding.

Sources: 1980-1991-Energy Information Administration, Uranium Industry Annual 1992 (October 1993). 1992-19e3-Energy Information Administration, Form ElA858. Uranlum Industry Annual Survey" (1993). 1990-1983, Government-owned uranium only-Office of Uranium Prognem (NE-30), U.S. Department of Energy, and the United States Enrichment Corporation (USEC). 


\section{Glossary}

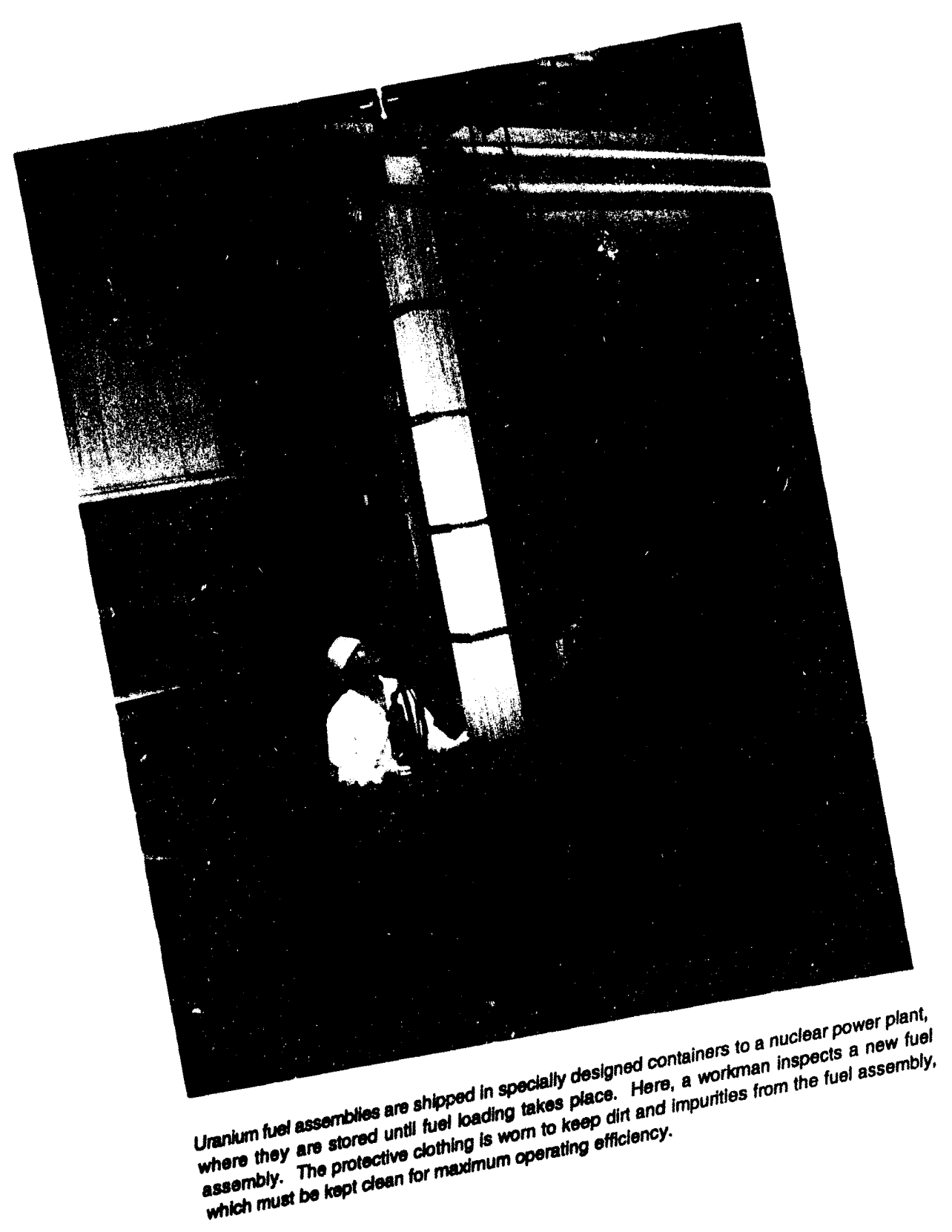




\section{Glossary}

Average delivered price: The weighted average of all contract-price commitments and market-price settlements in a delivery year.

Contract price: The delivery price determined when a contract is signed. It can be a fixed price or a base price escalated according to a given formula.

Conventional mill (uranium): A facility engineered and built principally for processing of uraniferous ore materials mined from the earth and the recovery, by chemical treatment in the mill's circuits, of uranium and/or other valued coproduct components from the processed ore.

Cost model for undiscovered resources: A computerized algorithm that uses the uranium endowment estimated for a given geological area and selected industry economic indexes to develop random variables that describe the undiscovered resources ultimately expected to be discovered in that area at chosen forward-cost categories.

Cutoff grade: The lowest grade, in percent $\mathrm{U}_{3} \mathrm{O}_{8}$, of uranium ore at a minimum specified thickness that can be mined at specified cost.

Development drilling: Drilling done to determine more precisely size, grade, and configuration of an ore deposit subsequent to the time the determination is made that the deposit can be commercially developed.

Domestic: Domestic means within the 50 States, District of Columbia, Puerto Rico, the Virgin Islands, Guam, and other U.S. possessions. The word "domestic" is used also in conjunction with data and information that are compiled to characterize a particular segment or aspect of the uranium industry in the United States.

Domestic uranium Industry: Collectively, those businesses (whether U.S. or foreign-based) that operate under the laws and regulations pertaining to the conduct of commerce within the United States and its territories and possessions and that engage in activities within the United States, its territories, and possessions specifically directed toward uranium exploration, development, mining, and milling; marketing of uranium materials; enrichment; fabrication; or acquisition and management of uranium materials for use in commercial nuclear power plants.

Enrichment feed deliveries: Uranium that is shipped under contract to a supplier of enrichment services for use in preparing enriched uranium product to a specified ${ }^{235} \mathrm{U}$ concentration and that ultimately will be used as fuel in a nuclear reactor.

Enriched uranium: Uranium in which the ${ }^{233} \mathrm{U}$ isotope concentration has been increased to greater than the 0.711 percent ${ }^{235} \mathrm{U}$ (by weight) present in natural uranium.

Exploration drilling: Drilling done in search of new mineral deposits, on extensions of known ore deposits, or at the location of a discovery up to the time when the company decides that sufficient ore reserves are present to justify commercial exploitation. Assessment drilling is reported as exploration drilling.

Fabricated fuel: Fuel assemblies composed of an array of fuel rods loaded with pellets of enriched uranium dioxide.

Floor price: A price specified in a market-price contracts as the lowest purchase price of the uranium, even if the market price falls below the specified price. The floor price may be related to the seller's production costs.

Forward cost: The operating and capital costs still to be incurred in the production of uranium from in-place reserves. By using forward costing, estimates of reserves for ore deposits in differing geological settings and status of development can be aggregated and reported for selected cost categories. Included are costs for labor, materials, power and fuel, royalties, payroll taxes, insurance, and applicable general and administrative costs. Excluded from forward cost estimates are prior expenditures, if any, incurred for property acquisition, exploration, mine development, and mill construction, as well as income taxes, profit, and the cost of muney. Forwand costs are neither the full costs of production nor the 
market price at which the uranium, when produced, might be sold.

Heap leach solutions: The separation, or dissolving-out, from mined rock of the soluble uranium constituents by the natural action of percolating a prepared chemical solution through mounded (heaped) rock material. The mounded material usually contains low grade mineralized material and/or waste rock produced from openpit or underground mines. The solutions are collected after percolation is completed and processed to recover the valued components.

Heavy water: Water containing a significantly greater proportion of heavy hydrogen (deuterium) atoms to ordinary hydrogen atoms than is found in ordinary (light) water. Heavy water is used as a moderator in some reactors, because it slows neutrons effectively and also has a low cross section for absorbtion of neutrons.

Heavy-water-moderated reactor: A reactor that uses heavy water as its moderator. Heavy water is an excellent moderator and thus permits the use of inexpensive natural (unenriched) uranium as fuel.

In situ leach mining (ISL): The recovery, by chemical leaching, of the valuable components of an orebody without physical extraction of the ore from the ground. Also referred to as "solution mining."

Light water reactor (LWR): A nuclear reactor that uses water as the primary coolant and moderator, with slightly enriched uranium as fuel. There are two types of commercial light-water reactors-the boiling-water reactor (BWR) and the pressurized-water resctor (PWR).

Long-term purchase: A purchase contract under which at least one delivery of material is scheduled to occur during the second calendar year after the contract-signing year. Deliveries also can occur during the contract-signing year, during the first calendar year thereafter, or during any subsequent calendar year.

Market price: The prevailing price level in the market at a given time. It generally reflects a published spot price, is mutually agreed upon by the contracting parties, or is independently determined by an unbiased outside arbitrator.

Market-price contract: A contract in which the price of uranium is not specifically determined at the time the contract is signed but is based instead on the prevailing market price at the time of delivery. A market-price contract may include a floor price, that is, a lower limit on the eventual settled price. The floor price and the method of price escalation generally are determined when the contract is signed. The contract may also include a price ceiling or a discount from the agreed-upon market price reference.

Market-price settlement: The price paid for uranium delivery under a market-price contract. The price is commonly (but not always) determined at or sometime before delivery and may be related to a floor price, ceiling price, or discount.

Milling of uranium: The processing of uranium from ore mined by conventional methods, such as underground or openpit methods, to separate the uranium from the undesired material in the ore.

National Uranium Resource Evaluation (NURE): A program begun by the U.S. Atomic Energy Commission (AEC) in 1974 to make a comprehensive evaluation of U.S. uranium resources and continued through 1983 by the AEC's successor agencies, the Energy Research and Development Administration (ERDA) and the Department of Energy (DOE). The NURE program included aerial radiometric and magnetic surveys, hydrogeochemical and stream sediment surveys, geologic drilling in selected areas, geophysical logging of selected boreholes, and geologic studies to identify and evaluate geologic environments favorable for uranium.

Net imports: The uranium imports minus exports in a given delivery period.

Nonconventional plant (uranium): A facility engineered and built principally for processing of uraniferous solutions that are produced during in situ leach mining, from heap leaching, or in the manufacture of other commodities, and the recovery, by chemical treatment in the plant's circuits, of uranium from the processed solutions.

Nuclear reactor: An apparatus in which a nuclear fission reaction, i.e., the splitting of atomic nuclei to release heat energy, can be initiated, controlled, and sustained at a specific rate. A reactor includes fuel (fissionable material), moderating materials to control the rate of fissioning, a heavy-walled pressure vessel to house reactor components, shielding to protect personnel, a system to conduct heat away from the reactor, and instrumentation for monitoring and controlling the reactor's systems. 
Optional delivery commitment: A provision to allow the conditional purchase or sale of a specific quantity of material in addition to the firm quantity in the contract.

Processing of uranium: The recovery of uranium from solutions produced by nonconventioanl mining methods, i.e., in situ leach mining (ISL), a byproduct of copper or phosphate mining, or heap leaching.

Purchase-contract imports of uranium: The amount of foreign-origin uranium material that enters the United States during a survey year as reported on the "Uranium Industry Annual Survey" (UIAS), Form EIA-858, as purchases of uranium ore. $\mathrm{U}_{3} \mathrm{O}_{8}$, natural $\mathrm{UF}_{6}$, or enriched $\mathrm{UF}_{6}$. The amount of foreign-origin uranium materials that enter the country during a survey year under other types of contracts, i.e., loans and exchanges, is excluded.

Separative Work Units (SWU): The standard measure of enrichment services. The effort expended in separating a mass $F$ of feed of assay $x f$ into a mass $P$ of product assay $x p$ and waste of mass $W$ and assay $x W$ is expressed in terms of the number of separative work units needed, given by the expression $\operatorname{SWU}=W V\left(x_{w}\right)+P V\left(x_{p}\right)$ $F V\left(x_{f}\right)$, where $V(x)$ is the "value function," defined as $V(x)=(1-2 x) \ln ((1-x) / x)$.

Short-term purchase: A purchase contract under which all deliveries of materials are scheduled to be completed by the end of the first calendar year following the contract-signing year. Deliveries can be made during the contract year, but deliveries are not scheduled to occur beyond the first calendar year thereafter.

Spot market: Buying and selling of uranium for immediate or very near-term delivery. It typically involves transactions for delivery of up to 500,000 pounds $\mathrm{U}_{3} \mathrm{O}_{8}$ within a year of contract execution.

Spot-market price: A transaction price concluded "on the spot," that is, on a one-time, prompt basis. The transaction usually involves only one specific quantity of product. This contrasts with a term-contract sale price, which obligates the seller to deliver a product at an agreed frequency and price over an extended period.

Unfilled requirements: Requirements not covered by usage of inventory or supply contracts in existence as of January 1 of the survey year.

Uranium: A heavy, naturally radioactive, metallic element (atomic number 92). Its two principally occurring isotopes are uranium-235 and uranium-238. Uranium-235 is indispensable to the nuclear industry because it is the only isotope existing in nature to any appreciable extent that is fissionable by thermal neutrons. Uranium-238 is also important because it absorbs neutrons to produce a radioactive isotope that subsequently decays to the isotope plutonium-239, which also is fissionable by thermal neutrons.

Uranium concentrate: A yellow or brown powder produced from naturally occurring uranium minerals as a result of milling uranium ore or processing uraniumbearing solutions. Synonymous with yellowcake, $\mathrm{U}_{3} \mathrm{O}_{8}$, or uranium oxide.

Uranium depodt: A discrete concentration of uranium mineralization that is of possible economic interest.

Uranium endowment: The uranium that is estimated to occur in rock with a grade of at least 0.01 percent $\mathrm{U}_{3} \mathrm{O}_{8}$. The estimate of the uranium endowment is made before consideration of economic availability and any associated uranium resources.

Uranium hexnfuoride (UF): A white solid obtained by chemical treatment of $\mathrm{U}_{3} \mathrm{O}_{8}$ and which forms a vapor at temperatures above 56 degrees Centigrade. $\mathrm{UF}_{6}$ is the form of uranium required for the enrichment process.

Uranium ore: Rock containing uranium mineralization in concentrations that can be mined economically, (typically 1 to 4 pounds of $\mathrm{U}_{3} \mathrm{O}_{3}$ per ton or 0.05 to 0.20 percent $\mathrm{U}_{3} \mathrm{O}_{8}$ ).

Uranium oxdde: Uranium concentrate or yellowcake. Abbreviated as $\mathrm{U}_{3} \mathrm{O}_{8}$.

Uranium property: A specific piece of land with uranium reserves that is held for the ultimate purpose of economically recovering the uranium. The land can be developed for production or undeveloped.

Uranium reserves: Estimated quantities of uranium in known mineral deposits of such size, grade, and configuration that the uranium could be recovered at or below a specified production cost with currently proven mining and processing technology and under current law and regulations. Reserves are based on diroct radiometric and chemical measurements of drill holes and other types of sampling of the deposits. Mineral grades and thickness, spatial relationships, dopths below the surface, mining and reclamation methods, distances to milling facilities, 
and amenability of ores to processing are considered in the evaluation. The amount of uranium in ore that could be exploited within the chosen forward-cost levels are estimated in accordance with conventional engineering practices.

Uranium resources categories: Three categories of uranium resources are used to reflect differing levels of confidence in the resources reported. Reasonably assured resources (RAR), estimated additional resources (EAR), and speculative resources (SR) are described below.

- Reasonably assured resources (RAR): The uranium that occurs in known mineral deposits of such size, grade, and configuration that it could be recovered within the given production cost ranges, with currently proven mining and processing technology. Estimates of tonnage and grade are based on specific sample data and measurements of the deposits and on knowledge of deposit characteristics. RAR correspond to DOE's uranium reserves category.

- Eotimated additional resources (EAR): The uranium in addition to RAR that is expected to occur, mostly on the basis of direct geological evidence, in extensions of well-explored deposits, little explored deposits, and undiscovered deposits believed to exist along well-defined geological trends with known deposits, such that the uranium can subsequently be recovered within the given cost ranges. Estimates of tonnage and grade are based on available sampling data and on knowledge of the deposit characteristics, as determined in the bestknown parts of the deposit or in similar doposits. EAR correspond to DOE's probable potential resources category.
- Speculative resources (SR): Uranium in addition to EAR that is thought to exist, mostly on the basis of indirect evidence and geological extrapolations, in deposits discoverable with existing exploration techniques. The locations of deposits in this category can generally be specified only as being somewhere within given regions or geological trends. The estimates in this category are less reliable than estimates of RAR and EAR. The category of SR corresponds to DOE's possible potential resources plus speculative potential resources categories combined.

Usage Agreement: Contracts held by enrichment customers that allow feed material to be stored at the enrichment plant site in advance of need.

Yellowcake: (See uranium oxide) 


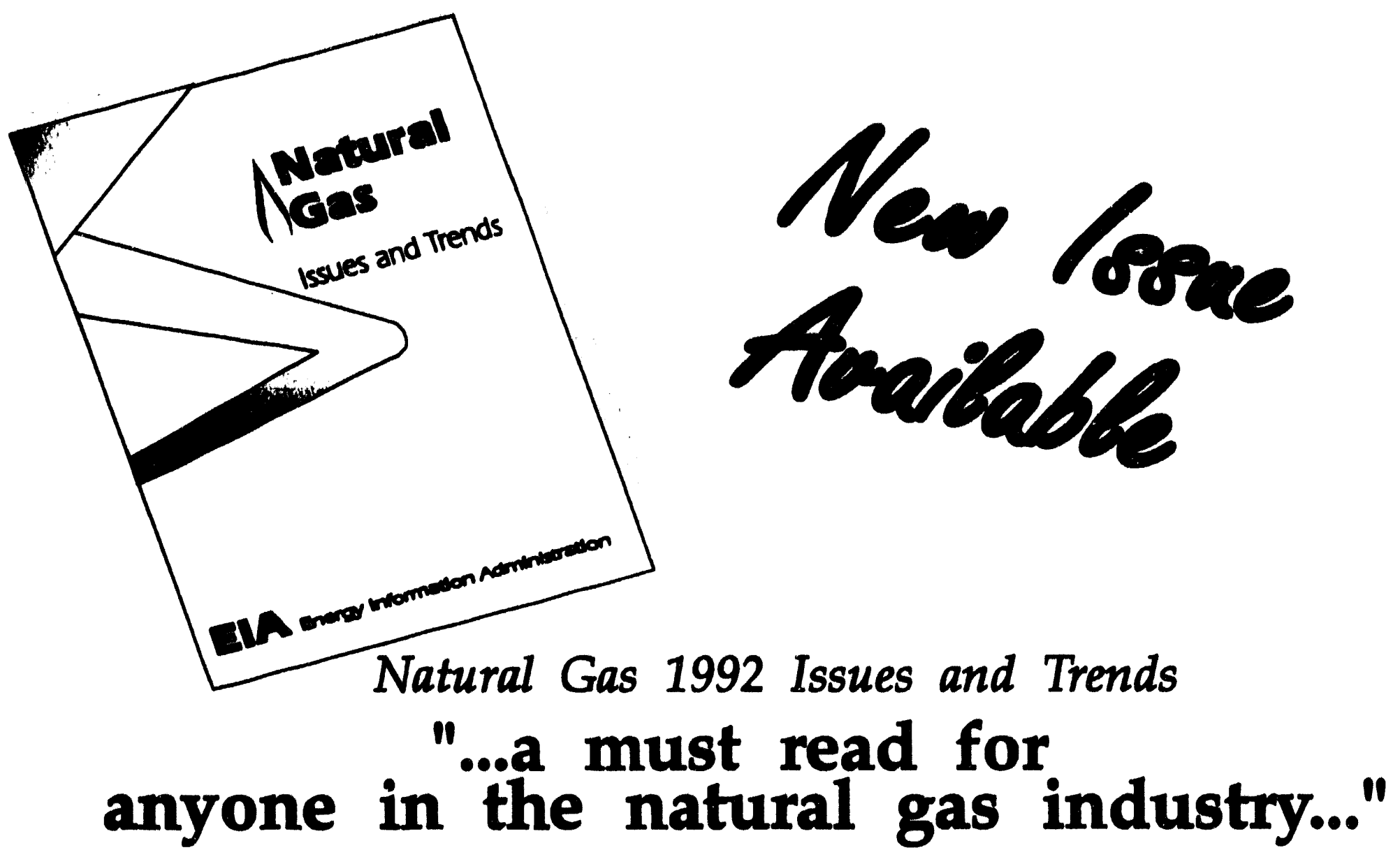

'...not the usual government tome rehashing old numbers, but a document with timely information that newcomers and old gas hands alike will find helpful..."

Gas Daily (April 12, 1993)

Our latest edition of Nourd Cos boues and Thends examines current events and trends affecting all segments of the natural gas industry, including: production, consumption, storage, prices, natural gas contracting, financial aspects of the industry, and recent regulatory and legislative developments.

MOR A COMPUMANTANYY CONY, FILL OUT AND MALL FORM BHLOW

Ploesese send me a copy of: Natural Gas 1994 lssues and Thends

NAME

ORENIZATION

STREET ADDRESS

arr

STATE

ZIPCODE

Mall To:

National Energy Information Center, Er-231

Energy iniormation Administration

U.S. Department of Energy

Washington, DC 20585 

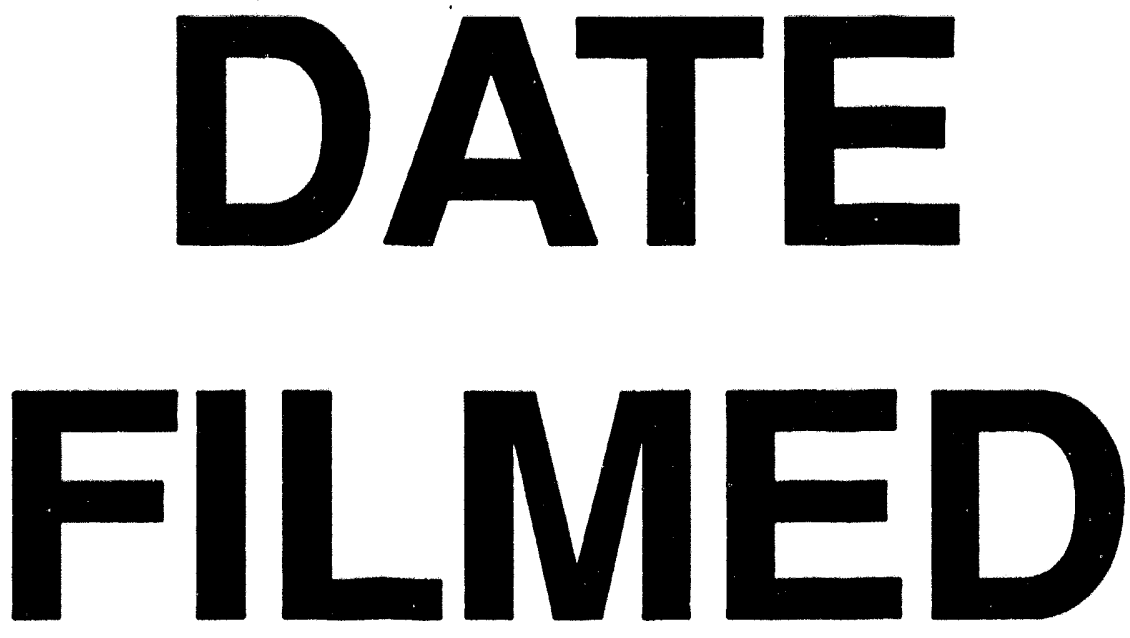

$10 / 05 / 94$
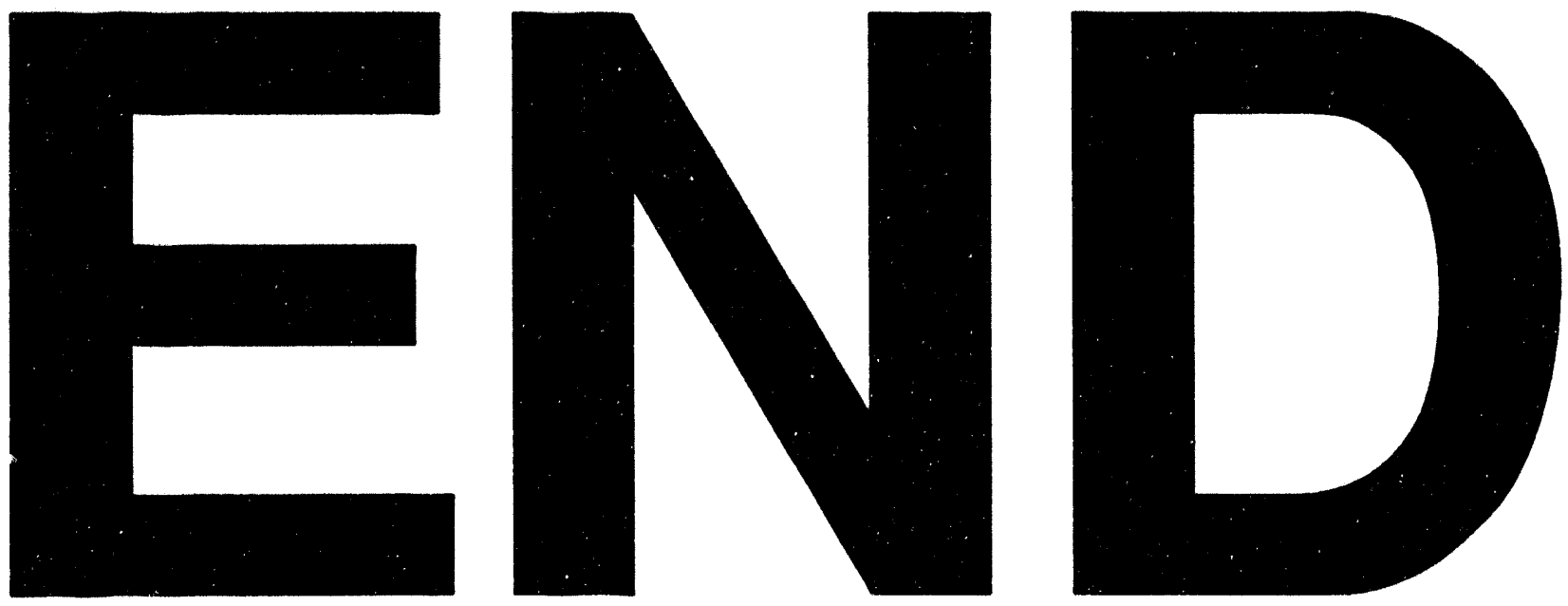
